Prepared for the Missouri River Recovery-Integrated Science Program U.S. Army Corps of Engineers, Yankton, South Dakota

\title{
Assessment of Lower Missouri River Physical Aquatic Habitat and Its Use by Adult Sturgeon (Genus Scaphirhynchus), 2005-07
}
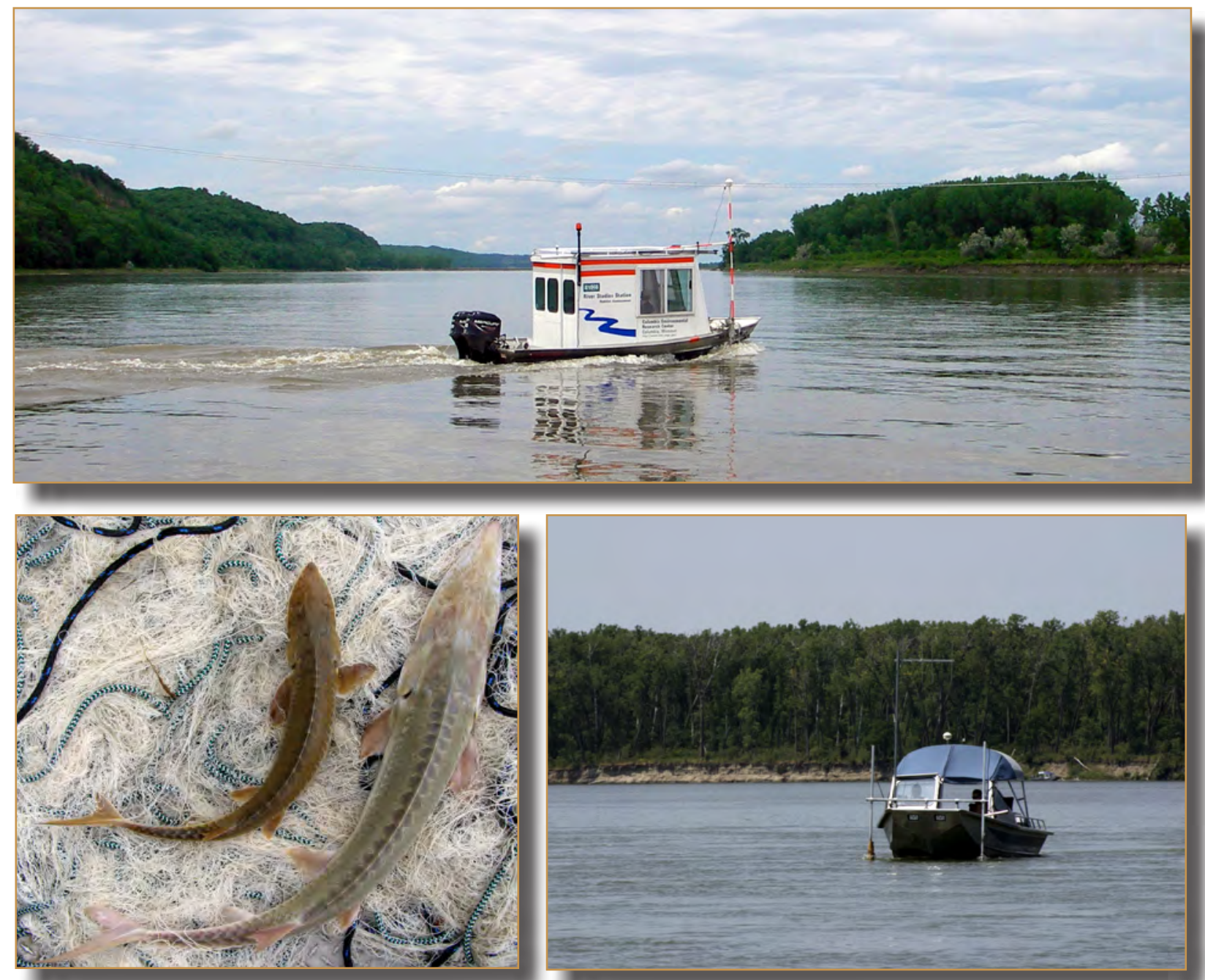

Scientific Investigations Report 2009-5121 
Cover. Top: Research vessel Slim Funk mapping physical aquatic habitat on the Lower Missouri River near Ponca, Nebraska. Bottom left: Shovelnose sturgeon (Scaphirhynchus platorynchus; on left) and pallid sturgeon (Scaphirhynchus albus; on right) from the Lower Missouri River. Bottom right: Sturgeon telemetry tracking boat on the Lower Missouri River. 


\section{Assessment of Lower Missouri River Physical Aquatic Habitat and Its Use by Adult Sturgeon (Genus Scaphirhynchus), 2005-07}

By Joanna M. Reuter, Robert B. Jacobson, Caroline M. Elliott, and Aaron J. DeLonay

Prepared for the Missouri River Recovery-Integrated Science Program U.S. Army Corps of Engineers, Yankton, South Dakota

Scientific Investigations Report 2009-5121 


\title{
U.S. Department of the Interior \\ KEN SALAZAR, Secretary
}

\author{
U.S. Geological Survey \\ Suzette M. Kimball, Acting Director
}

U.S. Geological Survey, Reston, Virginia: 2009

For more information on the USGS - the Federal source for science about the Earth, its natural and living resources, natural hazards, and the environment, visit http://www.usgs.gov or call 1-888-ASK-USGS

For an overview of USGS information products, including maps, imagery, and publications, visit http://www.usgs.gov/pubprod

To order this and other USGS information products, visit http://store.usgs.gov

Any use of trade, product, or firm names is for descriptive purposes only and does not imply endorsement by the U.S. Government.

Although this report is in the public domain, permission must be secured from the individual copyright owners to reproduce any copyrighted materials contained within this report.

Suggested citation:

Reuter, J.M., Jacobson, R.B., Elliott, C.M., and DeLonay, A.J., 2009, Assessment of Lower Missouri River physical aquatic habitat and its use by adult sturgeon (genus Scaphirhynchus), 2005-07: U.S. Geological Survey Scientific Investigations Report 2009-5121, 81 p. 


\section{Contents}

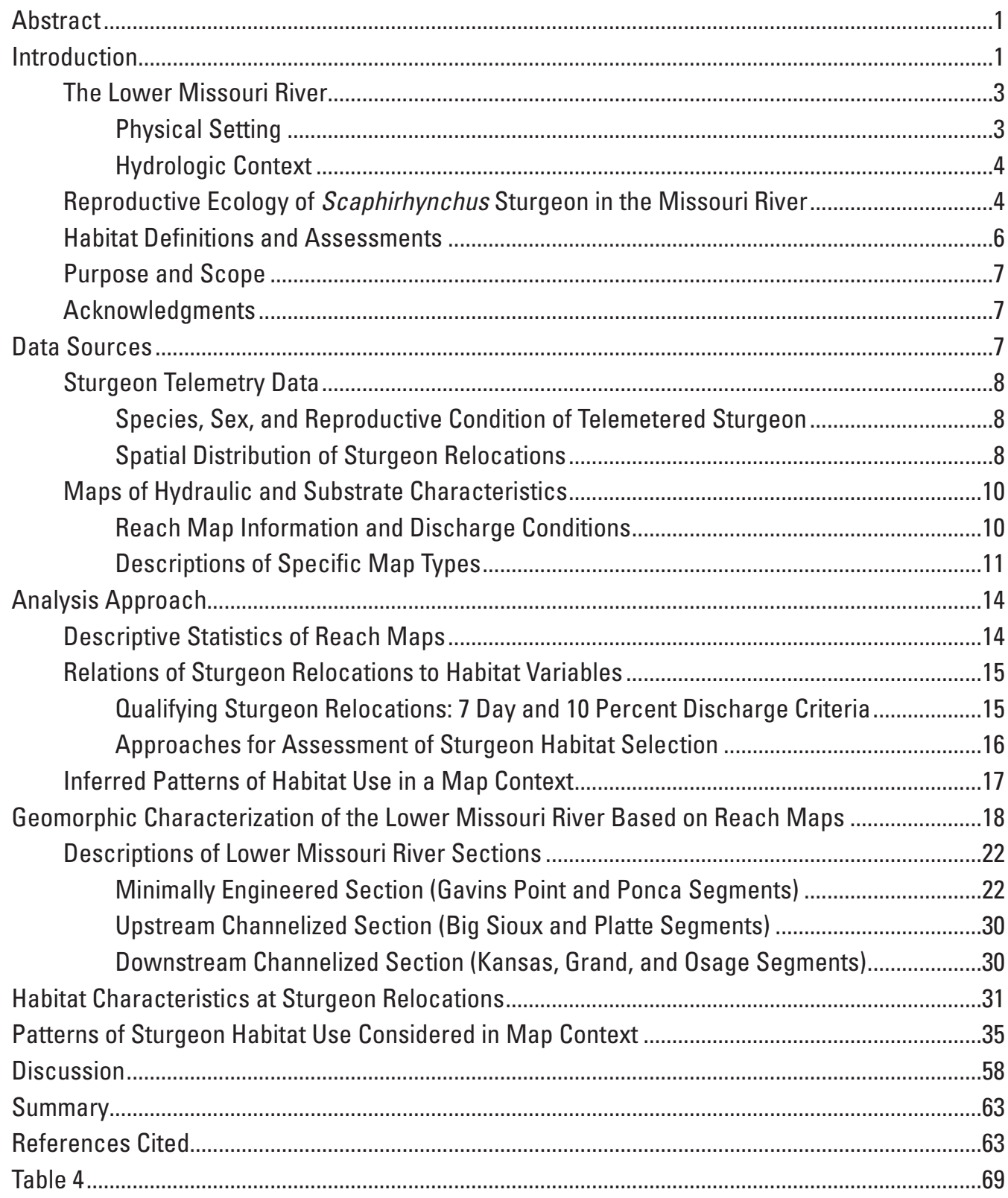




\section{Figures}

1. Map showing the Lower Missouri River ......................................................................

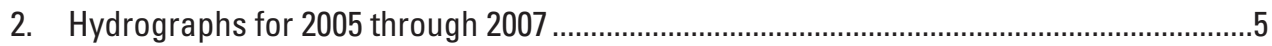

3-4. Plots showing-

3. Sturgeon telemetry and reach mapping activities, by date and river mile .9

4. Discharges on reach mapping dates in the context of flow exceedance data for the Lower Missouri River, based on daily discharge records............................10

5. Maps of an example reach

6. Illustration of the approach used to characterize sturgeon relocations by decile range of habitat used.....

7. Plots of reach geometry and related statistics by river mile 19

8. Schematic illustration of channel geometry and velocity characteristics, based on mean values by river segment..

9. Composite histograms by river segment for depth, depth slope, velocity, velocity gradient, and Froude number

10-13. Maps showing -

10. An example reach from the Minimally Engineered section .....................................22

11. An example reach from the Upstream Channelized section.....................................24

12. An example reach from the Downstream Channelized section ................................26

13. Examples of repeat mapping from each river section ............................................29

14-20. Histograms showing-

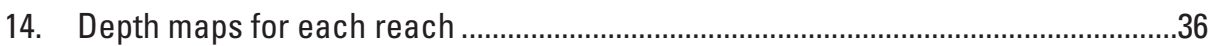

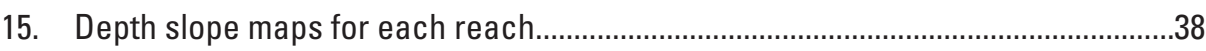

16. Velocity maps for each reach.............................................................................

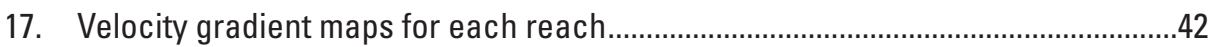

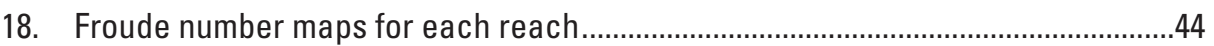

19. Composites of reach map data and values at qualifying sturgeon relocations......46

20. Histograms and Ivlev's selectivity coefficients for reach maps and qualifying sturgeon relocations, subdivided by river section.

21. Plots of percentage of reproductive female shovelnose sturgeon in each decile range, by river section, for each continuous variable.

22. Maps showing example maps from each river section showing the distribution of areas with high depth slope, high velocity gradient, and/or low Froude number.......59 


\section{Tables}

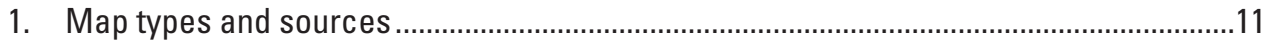

2. Bivariate relations among continuous variables for map data........................................28

3. Data for sturgeon individuals that were relocated within 7 days and 10 percent discharge of a reach map ..............................................................................................32

4. Reach map data for sturgeon relocations on reach maps within 7 days and 10 percent discharge

5. Number of relocations by decile for continuous and categorical variables compiled by sturgeon species, sex, reproductive condition, and river section ..............48

6. Number of relocations by decile for continuous variables for only reproductive female shovelnose sturgeon compiled by year

7. Categorical variables summarized by reach, including numbers of qualifying sturgeon relocations within 10 percent discharge and 7 days of the map date

7. Categorical variables summarized by reach, including numbers of qualifying sturgeon relocations within 10 percent discharge and 7 days of the map date..............56

8. Summary of categorical data by river section, including percent of map area, percent of relocations, and Ivlevs selectivity coefficient.

9. Comparison of distribution of shovelnose sturgeon relocations to distribution of high depth slope, high velocity gradient, and/or low Froude habitats... 


\section{Conversion Factors}

Inch/Pound to SI

\begin{tabular}{|c|c|c|}
\hline Multiply & By & To obtain \\
\hline \multicolumn{3}{|c|}{ Length } \\
\hline mile (mi) & 1.609 & kilometer $(\mathrm{km})$ \\
\hline \multicolumn{3}{|c|}{ Flow rate } \\
\hline cubic foot per second $\left(\mathrm{ft}^{3} / \mathrm{s}\right)$ & 0.02832 & cubic meter per second $\left(\mathrm{m}^{3} / \mathrm{s}\right)$ \\
\hline
\end{tabular}

SI to Inch/Pound

\begin{tabular}{lcl}
\hline \multicolumn{1}{c}{ Multiply } & By & \multicolumn{1}{c}{ To obtain } \\
\hline meter $(\mathrm{m})$ & Length & \\
kilometer $(\mathrm{km})$ & 3.281 & foot $(\mathrm{ft})$ \\
meter $(\mathrm{m})$ & 0.6214 & mile $(\mathrm{mi})$ \\
\hline & 1.094 & yard $(\mathrm{yd})$ \\
\hline square meter $\left(\mathrm{m}^{2}\right)$ & Area & \\
square kilometer $\left(\mathrm{km}^{2}\right)$ & 10.76 & square foot $\left(\mathrm{ft}^{2}\right)$ \\
& 0.3861 & square mile $\left(\mathrm{mi}^{2}\right)$ \\
\hline cubic meter per second $\left(\mathrm{m}^{3} / \mathrm{s}\right)$ & Flow rate & \\
meter per second $(\mathrm{m} / \mathrm{s})$ & 35.31 & cubic foot per second $\left(\mathrm{ft}^{3} / \mathrm{s}\right)$ \\
meter per day $(\mathrm{m} / \mathrm{d})$ & 3.281 & foot per second $(\mathrm{ft} / \mathrm{s})$ \\
\hline
\end{tabular}

To communicate effectively with stakeholders, managers, and other scientists working on the Lower Missouri River, this report uses a mix of U.S. customary units and International System of Units (SI) units of measure. Distances along the Missouri River are given in river miles upstream from the junction with the Mississippi River at St. Louis, Missouri, as measured by the U.S. Army Corps of Engineers in 1960. Discharges are provided in the customary units of cubic feet per second. Reach-scale hydraulic variables — velocity and depth — are in SI units of meters per second and meters.

Horizontal coordinate information is referenced to the World Geodetic System of 1984 (WGS 84). 


\title{
Assessment of Lower Missouri River Physical Aquatic Habitat and Its Use by Adult Sturgeon (Genus Scaphirhynchus), 2005-07
}

\author{
By Joanna M. Reuter, Robert B. Jacobson, Caroline M. Elliott, and Aaron J. DeLonay
}

\section{Abstract}

This report presents an exploratory analysis of habitat availability and use by adult Scaphirhynchus sturgeon on the Lower Missouri River from Gavins Point Dam, South Dakota, to the junction with the Mississippi River. The analysis is based on two main data sources collected from 2005 to 2007: (1) a compilation of 153 reach-scale habitat maps (mean reach length, 2.4 kilometers) derived from boat-collected hydroacoustic data and (2) a sturgeon location dataset from which 378 sturgeon telemetry locations are associated with the maps (within 7 days of the mapping and within 10 percent of the discharge). The report focuses on: (1) longitudinal patterns of geomorphic and hydraulic characteristics revealed by the collection of reach maps; (2) assessment of environmental characteristics at sturgeon locations in the context of the mapped reaches; and (3) consideration of spatial distribution of habitat conditions that sturgeon appear to select.

Longitudinal patterns of geomorphology, hydraulics, and associated habitats relate strongly to the engineered state of the river. Reaches within each of the following river sections tended to share similar geomorphic, hydrologic, and hydraulic characteristics: the Minimally Engineered section (Gavins Point Dam to Sioux City, Iowa), the Upstream Channelized section (Sioux City, Iowa, to the junction with the Kansas River), and the Downstream Channelized section (Kansas River to the junction with the Mississippi River).

Adult sturgeon occupy nearly the full range of available values for each continuous variable assessed: depth, depth slope, depth-averaged velocity, velocity gradient, and Froude number (a dimensionless number relating velocity to depth). However, in the context of habitat available in a reach, sturgeon tend to select some areas over others. Reproductive female shovelnose sturgeon (Scaphirhynchus platorynchus), in particular, were often found in parts of the reach with one or more of the following characteristics: high velocity gradient, high depth slope, low Froude number, and low (though not necessarily the lowest) depth-averaged velocity. Depths used by sturgeon varied considerably.
We explored spatial patterns representing the variable ranges that reproductive female shovelnose sturgeon most strongly and consistently selected by mapping areas within reaches meeting the following criteria: greater than the 80th percentile of depth slope, greater than the 80th percentile of velocity gradient, and less than the 20th percentile of Froude number. Our data exploration indicates that areas meeting these criteria have some predictive value regarding sturgeon habitat selection. Of all sturgeon locations that fall on maps from the same year ( sample size $=2,013$ ), about 63 percent fall within about 35 percent of the area where at least one variable meets the above criteria and 18 percent of locations fall within 4 percent of the area where all three variables meet the above criteria. The spatial patterns of these mapped areas show distinct differences among the sections of the Lower Missouri River. For example, the areas of predicted selection exhibit a relatively complex mosaic with multiple interconnected pathways in reaches of the Minimally Engineered section. In contrast, areas of predicted selection are concentrated along the channel margins in reaches of the Upstream Channelized section. Because the patterns described in this report represent habitat use in the context of the available habitat in a highly altered river system, selection may not necessarily indicate preferred habitats or habitats sufficient for reproduction and survival of sturgeon species.

\section{Introduction}

This report presents an analysis of fluvial habitat and habitat selection by Scaphirhynchus sturgeon on the Lower Missouri River downstream from Gavins Point Dam, South Dakota (fig. 1). The physical character of the Lower Missouri River has changed substantially relative to the historic condition because of human alteration, including impoundment and channelization (National Research Council, 2002; Galat and others, 2005b). In association with river alteration, a decline has occurred in native species and commercial fish catches (Hesse, 1987; Pflieger and Grace, 1987; Hesse and others, 


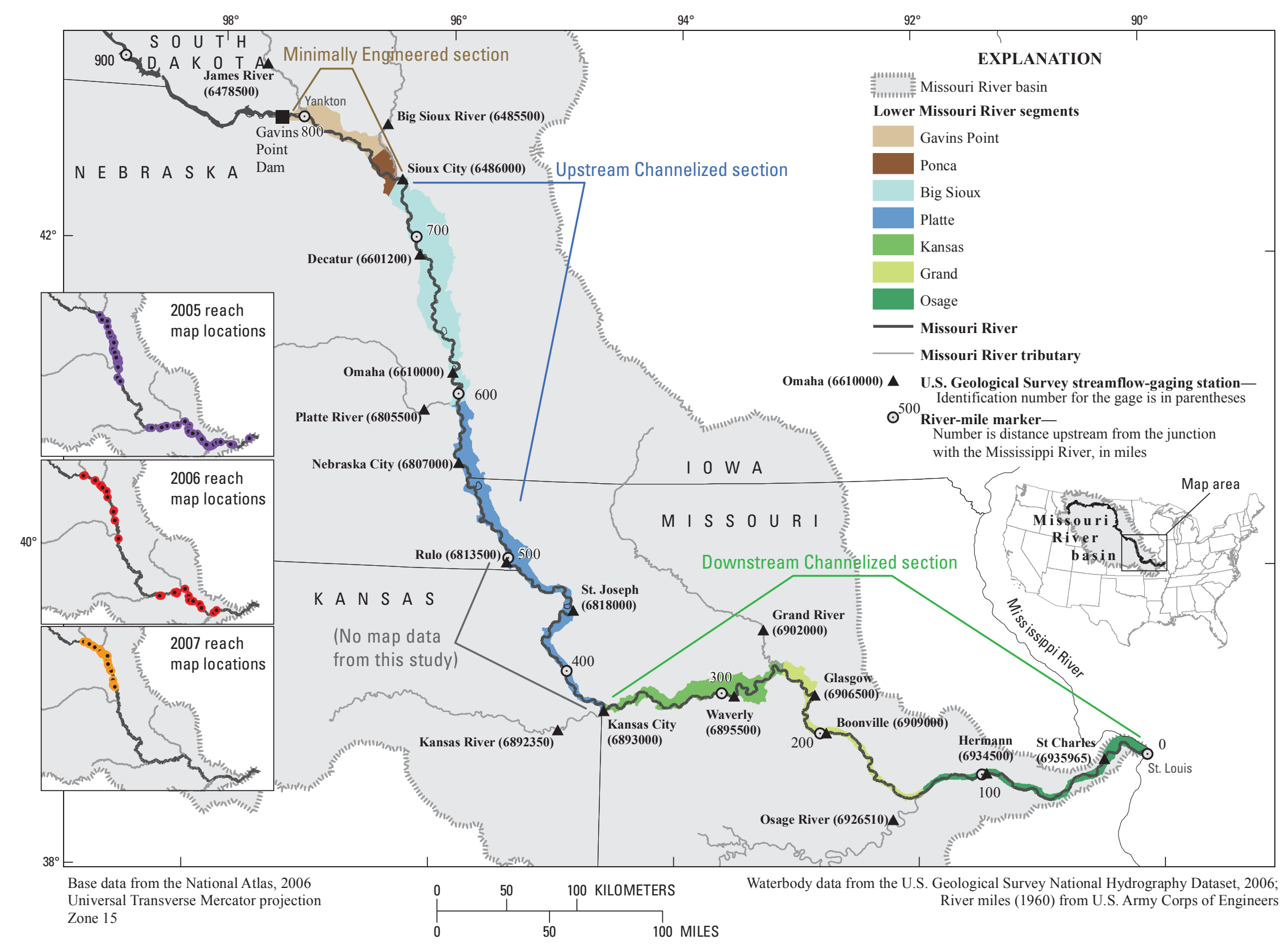

Figure 1. The Lower Missouri River, including insets showing the location of reach maps for each study year, 2005 through 2007. The Lower Missouri River is defined as the unimpounded length of the Missouri River extending from Gavins Point Dam to the junction with the Mississippi River. 
1989; Hesse and Sheets, 1993; U.S. Fish and Wildlife Service, 2000; Galat and others, 2005a).

Two of the declining species are native riverine sturgeon. The pallid sturgeon (Scaphirhynchus albus) is considered rare to extremely rare in the Missouri River and was listed as endangered in 1990 under the Federal Endangered Species Act (Dryer and Sandvol, 1993). The shovelnose sturgeon (Scaphirhynchus platorynchus), a more common, but closely related species, also inhabits the Missouri River and has been used as a comparative model for studying the pallid sturgeon (DeLonay and others, 2007b). Although shovelnose sturgeon are not endangered on the Missouri River, populations have similarly declined and the species has been excluded or extirpated from significant portions of its historic range (June, 1977; Moos, 1978; Keenlyne, 1997; Quist and others, 2002). The pallid sturgeon differs from the shovelnose sturgeon in that the pallid grows larger, matures later, lives longer, is more tolerant of turbidity, becomes piscivorous as an adult, and is primarily found only in the mainstem river and the downstream portions of larger tributaries (Keenlyne, 1997).

In 2000, and again in 2003, the U.S. Fish and Wildlife Service, in consultation with the U.S. Army Corps of Engineers, concluded that the operation and maintenance of the Missouri River mainstem and reservoir system jeopardized the continued existence of the pallid sturgeon (U.S. Fish and Wildlife Service, 2000, 2003). Included among the reasonable and prudent management actions detailed in the resultant Biological Opinion are significant efforts at flow modifications, habitat creation, and research and monitoring to enhance spawning, reproductive success, and survival of sturgeon. The U.S. Geological Survey (USGS) is engaged in the Comprehensive Sturgeon Research Program (CSRP), a multiyear, multi-agency program of research to understand Scaphirhynchus sturgeon life history, especially as related to reproduction and proposed management actions, in the Lower Missouri River (Korschgen, 2007). This report presents results from the habitat-use component of the broader sturgeon research project. The focus of the report is on understanding variability of physical habitat along the river, and on understanding which habitats among those available are selected by adult sturgeon - especially reproductive female shovelnose sturgeonduring the time of year that spawning occurs. The research is intended to contribute to a scientific basis for managing the highly altered Lower Missouri River to arrest the decline of native sturgeon species and to promote the recovery of the imperiled pallid sturgeon.

\section{The Lower Missouri River}

The Lower Missouri River extends approximately 1,305 kilometers (811 miles) from Gavins Point Dam, South Dakota, to the junction with the Mississippi River at St. Louis, Missouri (fig. 1). Gavins Point Dam is the downstream-most impoundment of the Missouri River reservoir system, which consists of six mainstem reservoirs that are operated to satisfy multiple objectives, including hydropower generation, flood control, water supply, and navigation. Dam operation has resulted in a change in both flow regime and sediment regime. Inter- and intraseasonal flow variability have been substantially altered (Galat and Lipkin, 2000) and sediment loads have declined to approximately one-sixth of historic loads at Hermann, Missouri (Jacobson and others, 2009a). The mainstem Missouri River is unimpounded downstream from Gavins Point Dam, but it has been channelized to allow for commercial barge navigation downstream from Sioux City, Iowa (river mile 734). In addition, the river has been subjected to changes in water quality because of agricultural and industrial development in the basin (Sprague and others, 2006; Alexander and others, 2008; Echols and others, 2008). Among the stresses imposed on the river, the large magnitude of changes in flow regime and channel morphology have been assumed to be the most influential in species declines, largely through their influence on physical habitat availability (National Research Council, 2002; U.S. Fish and Wildlife Service, 2003). Furthermore, flow regime and channel morphology are among the factors that can be addressed most readily through management action (Jacobson and Galat, 2006).

This report uses the terms reach, segment, and section to define lengths of river at various spatial scales (Frissell and others, 1986). Reaches are lengths of river up to a few kilometers that include bend and crossover habitats; from a logistics standpoint, reaches could be mapped in a single day (Reuter and others, 2008). Segments are intermediate in scale and primarily are defined by tributary junctions (fig. 1). At the broadest scale, sections are lengths of river that show broadly similar morphologic and engineering characteristics (fig. 1).

\section{Physical Setting}

In the 1800s, the Missouri River had a dynamically migrating, multithread channel with numerous islands and side channels, high sediment loads, abundant woody debris, and floods that frequently inundated the flood plain (Chittenden, 1903; Jacobson and others, 2009a). During the 1900s, engineering efforts succeeded in channelizing and stabilizing the planform of most of the Lower Missouri River. Downstream from Sioux City, Iowa, navigation structures were used to focus flow to maintain a single-thread, self-dredging navigation channel. Channel engineering resulted in the loss of as much as 400 square kilometers of river-corridor habitats, an amount that is approximately two-thirds of the habitat that existed prior to the Missouri River Bank Stabilization and Navigation Project (Funk and Robinson, 1974; Hesse and Sheets, 1993; Ferrell, 1996; National Research Council, 2002; U.S. Army Corps of Engineers, 2004; Galat and others, 2005b). The Biological Opinion issued by the U.S. Fish and Wildlife Service in 2000, and amended in 2003, called for the restoration of 48 to 79 square kilometers of shallowwater aquatic habitat lost because of river engineering, on the basis that lack of this habitat class jeopardized survival of the endangered pallid sturgeon (U.S. Fish and Wildlife 
Service, 2000, 2003). Shallow-water habitat, defined by the U.S. Fish and Wildlife Service as water 0 to 1.5 meters deep and 0 to 0.6 meters per second current velocity, was specified in particular because of its assumed importance for rearing of larval and juvenile pallid sturgeon and for other native fishes (U.S. Fish and Wildlife Service, 2003; U.S. Army Corps of Engineers, 2004). Projects to enhance habitat have included alteration of navigation structures (such as wing-dike notching) and construction of side-channel chutes (Jacobson and others, 2001, 2004).

The modern river varies substantially over its length because of contributions of tributaries, land-use patterns, and variation in channel engineering. The longitudinal variation is illustrated in a classification scheme that is based primarily on hydrologically defined segments bounded by junctions with major tributaries (fig. 1). Hydrologic variation among segments is evident in progressive downstream increase in intra-annual flow variability because of inputs from tributaries (fig. 2; Galat and Lipkin, 2000; Jacobson and Heuser, 2002; Pegg and others, 2003). Tributary junctions also have the potential to be locations of discrete changes in water quality because of land-use influences in the drainage basins; longitudinal variation in aquatic insect populations along the Lower Missouri River indicates that water-quality variations may be biologically significant (Poulton and others, 2003).

In addition to segment-scale hydrology, another factor that varies along the Lower Missouri River is channel engineering. Channel morphology is least disturbed relative to the historic (pre-engineered) condition in the non-navigation segment downstream from Gavins Point Dam, South Dakota, to Ponca State Park, Nebraska (Elliott and Jacobson, 2006). From Ponca State Park to Sioux City, Iowa, the river has been channelized and stabilized but is not used for commercial navigation so the construction is intermediate between the more natural channel upstream and the navigation channel that begins in Sioux City. From Sioux City, Iowa, to St. Louis, Missouri, the river has been channelized for commercial navigation and the banks have been stabilized to prevent erosion of the flood plain, resulting in narrowing and deepening of the channel, loss of habitat diversity, and changes to the relations between flow regime and habitat availability (Jacobson and Galat, 2006; Jacobson and others, 2009b).

Physiography of the Missouri River Valley also influences the river by determining valley width and geologic materials it interacts with in its banks. Just downstream from Gavins Point Dam, the river flows adjacent to glacial drift deposits that provide abundant coarse, hard substrate in those reaches (Laustrup and others, 2007). Between Yankton, South Dakota, and Sioux City, Iowa, the river flows for much of its length along bedrock bluffs that provide abundant bedrock and boulder substrate. At Sioux City, the river flows through a wide alluvial valley with little interaction with the valley wall until it enters the Ozark Plateaus Physiographic Province near Glasgow, Missouri. In this section of the river-mostly coincident with the hydrologically defined Grand and Osage segments - the valley narrows considerably and the river periodically encounters bedrock in its bed and banks (Laustrup and others, 2007).

\section{Hydrologic Context}

Prior to impoundment, the characteristic Missouri River hydrograph included two spring flood peaks (the first dominated by snow melt from the Great Plains and the second from the Rocky Mountains), followed by a low flow period later in the summer (fig. 2). Flow regulation has substantially affected the flow regime of the Lower Missouri River, resulting in reduced intra-annual flow variability, decreased spring pulses, and generally increased summer flows (Galat and Lipkin, 2000). The intensity of flow-regime alteration is most pronounced just downstream from Gavins Point Dam, and it diminishes in the downstream direction as tributaries enter the mainstem (fig. 2; Galat and Lipkin, 2000; Jacobson and Heuser, 2002; Pegg and others, 2003).

Natural flow regimes are considered important to ecosystem function; therefore, a common strategy for ecosystem recovery in impounded systems is to incorporate elements of the natural flow regime into managed flow releases (Poff and others, 1997; Galat and Lipkin, 2000). This is a strategy specified in the 2003 Amended Biological Opinion, which called for naturalization of the flow regime to provide spawning cues for the sturgeon, to connect the main channel periodically with low-lying flood plain, to build sandbars for nesting birds, and to improve the quality of sturgeon spawning habitats (U.S. Fish and Wildlife Service, 2003). During the study period, one pulsed release of about 9,000 cubic feet per second (260 cubic meters per second) was implemented from Gavins Point Dam in May 2006 (fig. 2) as an attempt to provide a sturgeon spawning cue (Jacobson and Galat, 2008).

River conditions varied over the course of this study because of the planned flow release as well as unplanned hydrologic conditions. Individual flow pulses during 2005 through 2007 were uniformly small in the upstream section, achieving no more than 15 percent flow exceedance at Sioux City. In all 3 years, flow pulses substantially larger than the 2006 release were evident downstream from the Platte River (fig. 2). For example, a flood pulse during May 2007 attained a 0.9 percent exceedance at the USGS streamflow-gaging station at Nebraska City, Nebraska and qualified as a 5- to 10-year recurrence interval flood at the Boonville, Missouri, gaging station (fig. 2).

\section{Reproductive Ecology of Scaphirhynchus Sturgeon in the Missouri River}

Sturgeon experts have identified sturgeon spawning requisites as a research priority (Quist and others, 2004; Wildhaber and others, 2007a; Bergman and others, 2008), in part because the precise spawning requirements for Scaphirhynchus sturgeon are largely unknown and because little to no recruitment is occurring among pallid sturgeon in the Missouri 

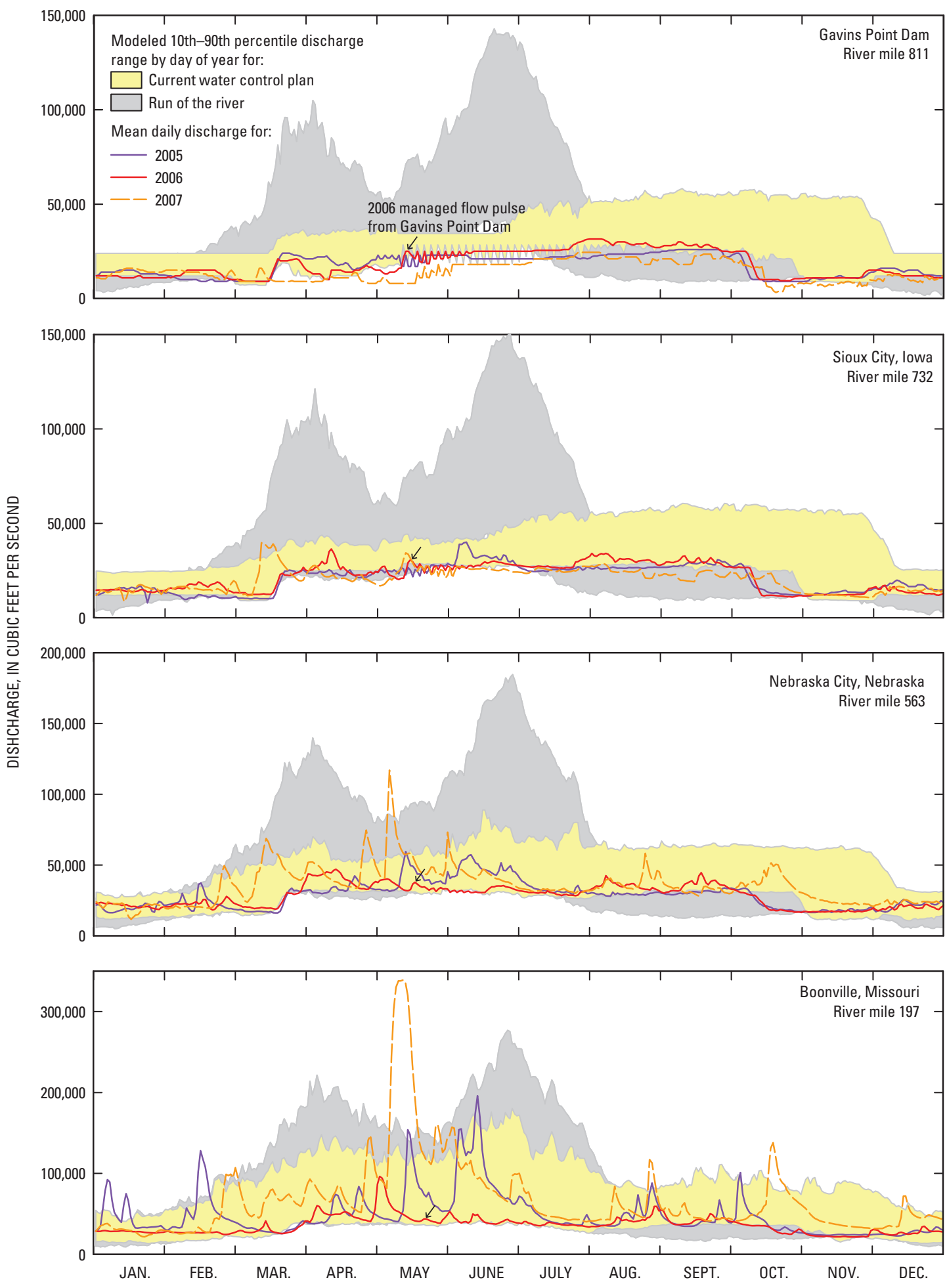

Figure 2. Hydrographs for 2005 through 2007. The shaded areas provide context for the range of flows expected under unmanaged conditions and under the current water control plan. "Run-of-the-river" conditions represent flows that would occur in the absence of dams (Jacobson and Heuser, 2002). 
Assessment of Lower Missouri River Physical Aquatic Habitat and Its Use by Adult Sturgeon (Genus Scaphirhynchus), 2005-07

River (U.S. Fish and Wildlife Service, 2000). In contrast, some successful recruitment is occurring among shovelnose sturgeon (Moos, 1978; Keenlyne, 1997). During 2005 through 2007, CSRP research efforts focused on following the movements of reproductive female shovelnose sturgeon to provide insight on various aspects of reproductive ecology. Subsequent efforts have shifted the focus to comparative assessments of pallid sturgeon.

The time to reach reproductive maturity is estimated to be approximately 7 years for female shovelnose sturgeon (Keenlyne, 1997) and nearly a decade or more for female pallid sturgeon (Keenlyne and Jenkins, 1993). Female shovelnose sturgeon may spawn as often as once every 2 to 3 years, while pallid sturgeon females are thought to spawn only once every 3 to 10 years (Mayden and Kuhajda, 1997). Female sturgeon with black eggs in the spring are in condition to spawn that spring or summer (Wildhaber and others, 2007b).

All sturgeon species spawn in freshwater with most migrating upstream from marine or estuarine environments to deposit their eggs in the upper reaches of larger rivers. The timing and length of spawning migrations varies among sturgeon species and may range over hundreds to thousands of kilometers from adult feeding or wintering areas (Auer, 1996). For some sturgeon species, a phase of the upstream migration may occur during fall prior to the final spawning run (Bemis and Kynard, 1997).

Scaphirhynchus sturgeon live exclusively in the large freshwater rivers of mid-continental North America and do not thrive in reservoirs or move downstream into estuarine environments (Wilson and McKinley, 2004). In preparation for spawning, reproductive Scaphirhynchus sturgeon migrate upstream on the order of tens to hundreds of kilometers, as documented by telemetry studies on the Missouri River (DeLonay and others, 2007b). Spawning of Scaphirhynchus species is hypothesized to occur near the apex, or most upstream point, of a female's migratory path, although the specific location and success of spawning by telemetered sturgeon remains to be validated through egg or larvae collection. Missouri River sturgeon tend to reach their migratory apex locations during late spring and early summer, as determined from telemetry data (Aaron J. DeLonay, unpub. data, 2008). Historically, large flow pulses were typical during the period of sturgeon migration on the Missouri River, leading to the hypothesis that sturgeon may require a flow pulse to act as a spawning cue (U.S. Fish and Wildlife Service, 2003; Jacobson and Galat, 2008). High river discharge and the increasing daylight of spring are associated with the period of spawning for many sturgeon species (Cech and Doroshov, 2004).

Specific spawning locations and the relative suitability of spawning conditions for these sturgeon species in the Lower Missouri River are not known conclusively. Hard, coarse substrate is assumed to be suitable spawning substrate based on spawning requirements of other sturgeon species (Bemis and Kynard, 1997), and recent studies on the Lower Missouri River have mapped the distributions of such substrate (Laustrup and others, 2007). In 2008, three reproductive female pallid sturgeon were tracked to inferred spawning patches on the outsides of river bends covered with riprap revetment (Aaron J. DeLonay, unpub. data, 2008). Subsequent recapture verified that eggs had been released; however, the specific site of egg deposition was not confirmed through egg or larvae collection.

Sturgeon migratory behavior varies by sex and reproductive condition as well as among individuals. Habitat use may also depend on these factors. Telemetry studies have documented that reproductive male sturgeon have less systematic upstream migrations and nonreproductive female sturgeon typically do not migrate upstream (Aaron J. DeLonay, unpub. data, 2008). Furthermore, a substantial amount of variation exists in the observed rate and distance of the upstream migration among reproductive individuals. Not all black-egged female sturgeon spawn successfully or completely; some resorb their eggs because of factors that are not fully understood (DeLonay and others, 2007a; Papoulias and others, 2007).

A variety of questions exist regarding whether habitat for migration or spawning is limiting for reproduction of the pallid sturgeon. Key questions include: (1) Has alteration of the Missouri River decreased the availability of low-velocity pathways for migratory sturgeon, resulting in increased rates of energy expenditure and decreased spawning success? (2) Has alteration of the Missouri River decreased or modified quantity or quality of spawning habitat patches? (3) Has the altered distribution and availability of habitats changed the timing and duration of migration or altered the location and timing of spawning? (4) Has habitat had a role in reducing reproductive isolation between species and increasing the apparent rate of hybridization in sturgeon? (5) Are engineered habitat features used by sturgeon for migration and spawning, and how does habitat quality compare to pre-engineered habitats?

\section{Habitat Definitions and Assessments}

Fish habitat is defined as the place or a set of places where a fish, a fish population, or a fish assemblage finds suitable environmental features to survive and reproduce (Orth and White, 1999). Habitat for a particular species consists of all the characteristics of all the places that the fish may occupy during its life history. For Missouri River sturgeon that migrate long distances during their lives (DeLonay and others, 2007b), habitat assessments may, therefore, need to consider a wide range of conditions at a wide range of locations. A more restricted definition of physical habitat is the 3-dimensional structure of physical and chemical characteristics in which a riverine organism lives; time variation in these characteristics (frequency, duration, sequence, rate of change) adds a critical fourth dimension that must be assessed (Gordon and others, 1992). Of a wide range of physical and chemical characteristics, depth, current velocity, and substrate are the three main characteristics of physical habitat that are usually evaluated. Other factors like water temperature and turbidity 
can be important habitat components and often covary with the physical components. Physical components of habitat can be managed directly by changes in flow regime or channel morphology (Jacobson and Galat, 2006).

A central challenge in fish habitat assessment is to relate habitats used by a fish to all available habitats in order to evaluate whether the fish select specific habitats over others. Habitat selection is a measure of relative choice of habitat from the range that is readily available to the fish; habitat preference is a measure of relative choice if all possible habitats are available (Hall and others, 1997). In the case of field studies in a river like the Lower Missouri, selection indicates choice among available habitat patches, none of which may be preferred or sufficient for a particular life stage.

Availability is conditioned by water discharge, as physical characteristics like depth and velocity are highly dependent on discharge. Therefore, use and availability should be considered simultaneously or at equivalent discharges in order to assess selection.

Existing literature on Scaphirhynchus sturgeon provides information regarding sturgeon habitat use, but most studies have not addressed reach-scale habitat availability or selection. Scaphirhynchus sturgeon are primarily benthic, but the literature supports the idea that adult pallid sturgeon do not select strongly for river depth. For example, pallid sturgeon in the Mississippi River used a wide range of depths, 1.8 to 19.1 meters (Hurley, 1999) and pallid sturgeon in the Upper Missouri and Yellowstone Rivers were captured at 0.6 to 14.5 meters depth (Bramblett and White, 2001). Depth selection of other fishes is often thought to relate the cover that depth provides for predator avoidance rather than a hydraulic effect on the fish (Rabeni and Jacobson, 1999), and this effect would be expected to vary with turbidity. However, adult pallid sturgeon have few predators and selected habitats may be related more to the availability or habitat selection of prey species.

Pallid sturgeon selection for velocity may be stronger than for depth. Adult pallid sturgeon have been found at a fairly narrow range of velocities: 0 to 1.37 meters per second in the Upper Missouri and Yellowstone Rivers (Bramblett and White, 2001) and 0.17 to 0.97 meters per second in the Platte River (Snook and others, 2002).

\section{Purpose and Scope}

This report presents an exploratory analysis of habitat maps of Lower Missouri River reaches (Reuter and others, 2008) and associated sturgeon relocations (DeLonay and others, 2007b; Aaron J. DeLonay, unpub. data, 2008) with the objective of providing information about habitats selected by adult Scaphirhynchus sturgeon, especially reproductive female shovelnose sturgeon, during the spring and summer. The mapped reaches provide a basis for characterization of aspects of the geomorphology of the Lower Missouri River, including broad patterns of longitudinal variability of the river from
Gavins Point Dam to the junction with the Mississippi River. In the context of the geomorphic setting, the sturgeon locations associated with mapped reaches reveal trends of habitat selection. Presentation of results includes an extensive set of tables intended to make data publically available; however, we discuss only the highlights of this large dataset. Data collection was not targeted at specific, a priori hypotheses; thus, we do not use statistical hypothesis testing in this report. Instead, the exploratory approach used was intended to investigate trends and to generate working hypotheses.

\section{Acknowledgments}

Funding for this project was provided by the U.S. Army Corps of Engineers, Missouri River Recovery_-Integrated Science Program and the USGS. This work is part of the Comprehensive Sturgeon Research Program (CSRP), a large, interdisciplinary, multiyear, multi-agency research project to which many individuals have contributed. The following individuals assisted with hydroacoustic mapping: Harold Johnson, III (USGS), Matt Smith (Arctic Slope Regional Corporation, ASRC), Chad Vishy (ASRC), Mark Laustrup (USGS), and David Gaeuman (National Research Council Post-Doctoral Fellow). Sturgeon telemetry crews tagged and tracked sturgeon. Crews were supervised by Aaron DeLonay (USGS) and led by Sabrina Davenport (ASRC) and David Combs (ASRC). Core crew members included: Brian Carollo (ASRC), Jermyn Porter (ASRC), Caleb Troutt (ASRC), Daniel Schertz (ASRC), and Kyle Singer (ASRC). Tracking crews with the Nebraska Game and Parks Commission provided some of the telemetry locations in 2007. Kim Chojnacki, Emily Tracy-Smith, Sandy Clark-Kolaks, and Emily Kunz (USGS) provided support through management and quality control of the sturgeon telemetry data. Diana Papoulias, Mandy Annis, and Janice Bryan (USGS) provided data concerning the sex and reproductive condition of telemetered sturgeon. Many additional individuals have provided indirect support; the chapters of the volume edited by Korschgen (2007) contain acknowledgments for numerous other individuals involved with the CSRP. Color schemes for some maps were inspired by Color Brewer, http:// colorbrewer.org. Lewis Coggins and Edward Little (USGS) reviewed this report.

\section{Data Sources}

This section provides basic background information on the two source datasets that were the focus of analysis for this report. The two data sources are: (1) a sturgeon telemetry dataset with thousands of recorded sturgeon positions in the 2005 through 2007 time period (DeLonay and others, 2007b; Aaron J. DeLonay, unpub. data, 2008) and (2) a set of reach-scale maps that are associated with a subset of the sturgeon telemetry locations (Reuter and others, 2008). Maps depict depth, depth-averaged velocity, and substrate, as well as habitat characteristics 
derived from these variables. Thus, for a set of known sturgeon locations, maps provide data for environmental characteristics at the sturgeon coordinate locations, assuming the that discharge and bed configuration did not vary substantially between sturgeon location and mapping. In addition, the maps provide the context of habitat availability in the reach surrounding the sturgeon. Here we provide an overview of these datasets; additional information has been documented in other published reports (Korschgen, 2007; Reuter and others, 2008).

\section{Sturgeon Telemetry Data}

The telemetry project involved capturing sturgeon from the Missouri River, implanting selected individuals with combined acoustic and radio transmitters, and tracking these telemetered sturgeon to obtain relocations of the sturgeon over time (DeLonay and others, 2007a; DeLonay and others, 2007b). We use the term "relocation" to refer to a point location where a sturgeon was found again through telemetry tracking, and not as a reference to an act of moving something from one place to another. Sturgeon were captured and implanted during the late winter and early spring of 2005, 2006, and 2007. In total, more than 400 sturgeon were tagged and implanted with transmitters during these 3 years. After release and a recovery period, telemetered sturgeon were tracked to determine their movement patterns. Crews tracked sturgeon by navigating through sections of river, using boats outfitted with acoustic and radio receivers to determine the locations of telemetered sturgeon. These relocation points, accurate to approximately 2 meters, were obtained using a differential global positioning system (DGPS) receiver and recorded in Universal Transverse Mercator (UTM) coordinates, Zone 15 North, using the World Geodetic System of 1984 (WGS 84) datum. The crews recorded more than 6,200 sturgeon relocation positions in 2005 through 2007. A subset of the telemetered sturgeon were recaptured to assess the spawning success of individuals.

\section{Species, Sex, and Reproductive Condition of Telemetered Sturgeon}

Sturgeon were selected for implantation based on size and field assessments of species, sex, and reproductive condition at the time of initial capture in the spring. Blood and egg samples were taken to confirm sex and reproductive condition in the lab (Papoulias and others, 2007; Wildhaber and others, 2007b). All implanted sturgeon were adults. Female sturgeon with black eggs at the time of initial capture were considered to be in reproductive condition, with a high probability of spawning that year. Female sturgeon that did not have black eggs at initial capture were unlikely to spawn that year (Moos, 1978); we refer to these sturgeon as nonreproductive. Male sturgeon also were assessed with regard to reproductive condition using the criteria in Wildhaber and others (2007b). In 2005 and 2006, all telemetered shovelnose sturgeon were reproductive females. In
2007, telemetered shovelnose sturgeon also included males and females in a range of reproductive stages, including sturgeon not expected to spawn in that year. A few pallid sturgeon were also included in each year from 2005 through 2007. Overall, the majority of sturgeon during this time period were reproductive female shovelnose sturgeon.

The reproductive designations used in this report are based on the condition at initial capture because this is the only reproductive assessment that is available for all sturgeon in the study. For a subset of telemetered sturgeon that were recaptured later in the year, assessments of spawning success based on field observations and laboratory assessments of gonad tissue also are available. However, we do not have sufficient data to consistently and confidently differentiate between locations that represent sturgeon in prespawn versus postspawn condition, nor do we have data regarding spawning success for all individuals. Therefore, in this report, we used the assessment of reproductive condition at initial capture to classify sturgeon reproductive condition for the entire season.

\section{Spatial Distribution of Sturgeon Relocations}

The regional distribution of sturgeon relocations is a byproduct of sample design and search effort (fig. 3). During 2005 and 2006, the CSRP sample design called for comparison between upstream and downstream locations in an attempt to isolate the effects of flow regulation on sturgeon reproduction. The upstream segments have highly regulated flow regimes and few spring flow pulses (fig. 2). The upstream segments also have the potential for manipulated pulsed-flow experiments like the one in 2006. The downstream segments have less-regulated flows and have a very high probability of experiencing natural spring flow pulses in every year. Downstream sturgeon initial capture/release locations were in the Missouri River between the Osage River and the Kansas River junctions, and the upstream sturgeon were captured/released between the junctions of the Platte River and the Vermillion River in South Dakota. During 2007, all initial capture/release locations were upstream from the Platte River.

On a reach scale, locations are minimally biased by search effort. The presence of the boat during tracking in the Missouri River had minimal impact on the activity and behavior of the sturgeon. Telemetered positions could be accurately located by placing the boat directly over the sturgeon (DeLonay and others, 2007b). Limitations do exist to the extent that sturgeon can only be relocated in areas deep enough to be navigable by the tracking boats. This is of primary concern in the segment downstream from Gavins Point Dam to Ponca State Park, where shallow water and multithread channels are prevalent. Additionally, some difficulties exist in locating telemetered sturgeon during very high water because of high acoustic noise associated with increased suspended sediment and bedload, as well as the proliferation of acoustic shadows where sturgeon can hide behind large bedforms or submerged engineered structures. On the whole, the 


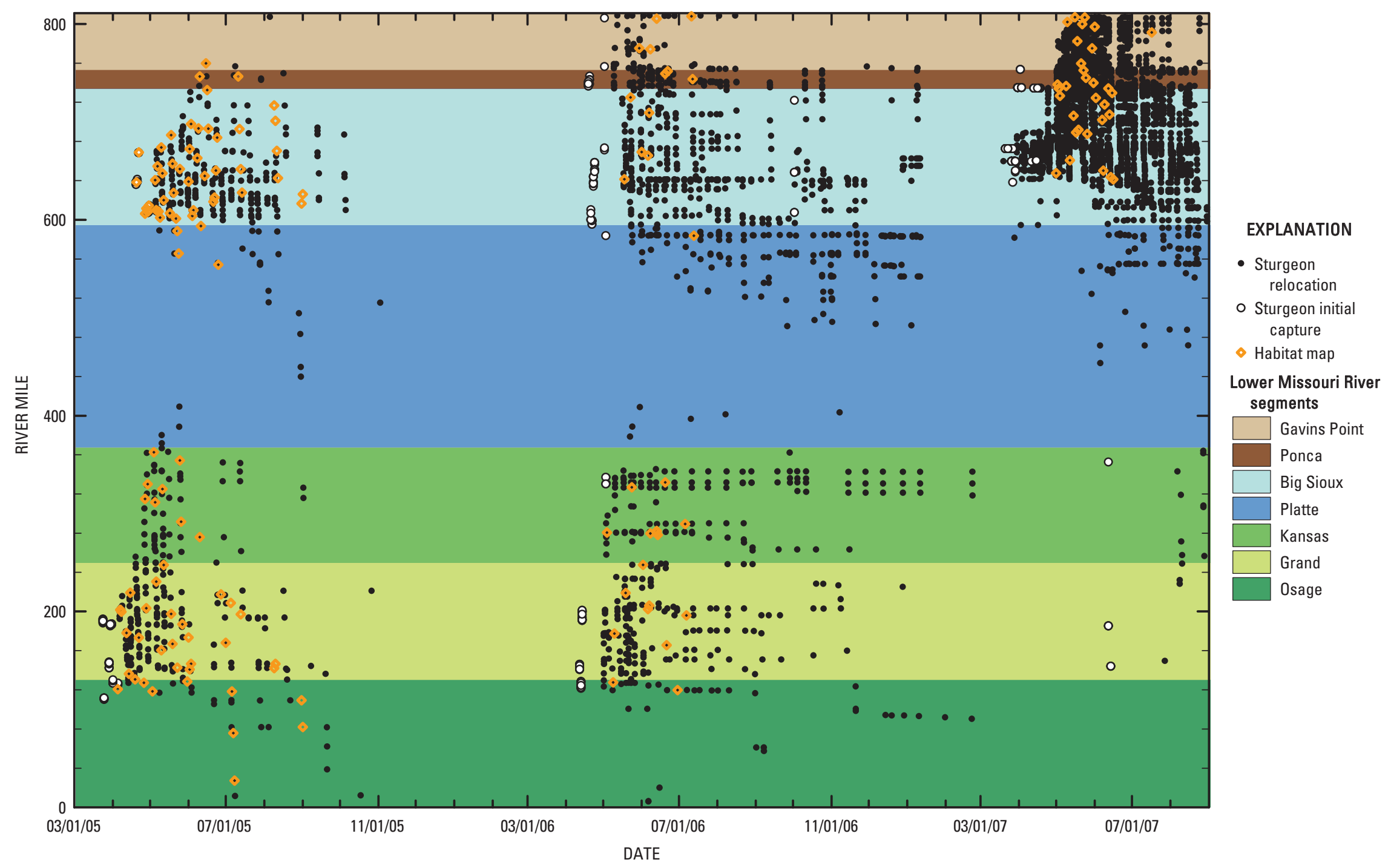

Figure 3. Plot of sturgeon telemetry and reach mapping activities, by date and river mile. In 2005 and 2006, telemetry and mapping efforts were divided between upstream and downstream parts of the Lower Missouri River. In 2007, effort was largely focused in the upstream part of the river. Relocations illustrate the broad patterns of search effort. 
sturgeon relocations provide a relatively thorough sampling of where sturgeon are found within river reaches.

\section{Maps of Hydraulic and Substrate Characteristics}

Maps based on boat-collected hydroacoustic data depict hydraulic and substrate characteristics at sturgeon relocations and in surrounding reaches. These maps, along with a detailed description of methods used to derive them, were published in Reuter and others (2008). Maps were made at the reach scale (mean reach length, 2.4 kilometers) in order to include the immediate vicinity of a targeted sturgeon relocation as well as the full range of habitat available at the bend and crossover scale. Reaches typically were surveyed on the day following the relocation of a telemetered sturgeon and at a discharge within 10 percent of the discharge on the sturgeon relocation date in order to characterize as closely as possible the channel morphology and flow-field conditions at the time that the sturgeon was present.

\section{Reach Map Information and Discharge Conditions}

One-hundred fifty-three reaches were mapped during the months of April to September of 2005 through 2007, with the majority of data collection occurring in the months of May and June (coinciding with the period of sturgeon migration and spawning in the Lower Missouri River). Many maps were based on random selection of target Scaphirhynchus sturgeon (primarily shovelnose). Other maps were made based on nonrandom selection of target sturgeon for a variety of reasons; some of these nonrandom maps included suspected spawning locations, as inferred from information available at the time of mapping. Specific spawning locations were not verified during the time period in question. We consider all maps, random and nonrandom, in the exploratory analysis presented in this report. One-hundred twelve of the maps contain sturgeon relocations within an acceptable date and discharge range (see section on "Qualifying Sturgeon Relocations").

Discharges at the time of mapping spanned a range of flow conditions in terms of flow exceedance and discharge (fig. 4). Flow exceedance values indicate how frequently flows of a given discharge are equaled or exceeded at a particular location based on a record of past discharge. We computed Missouri River flow exceedances from mainstem gages during the period of regulated flows from 1967 through 2008 (Galat and Lipkin, 2000). Most maps were made when discharges were moderate to low relative to annual data. No overbank flows were mapped during this study. The lowest flows at the time of mapping, in terms of both absolute discharge and flow exceedance, were between Gavins Point Dam and the first major tributary, the James River, during early May 2007 when the James, Vermillion, and Big Sioux Rivers were contributing

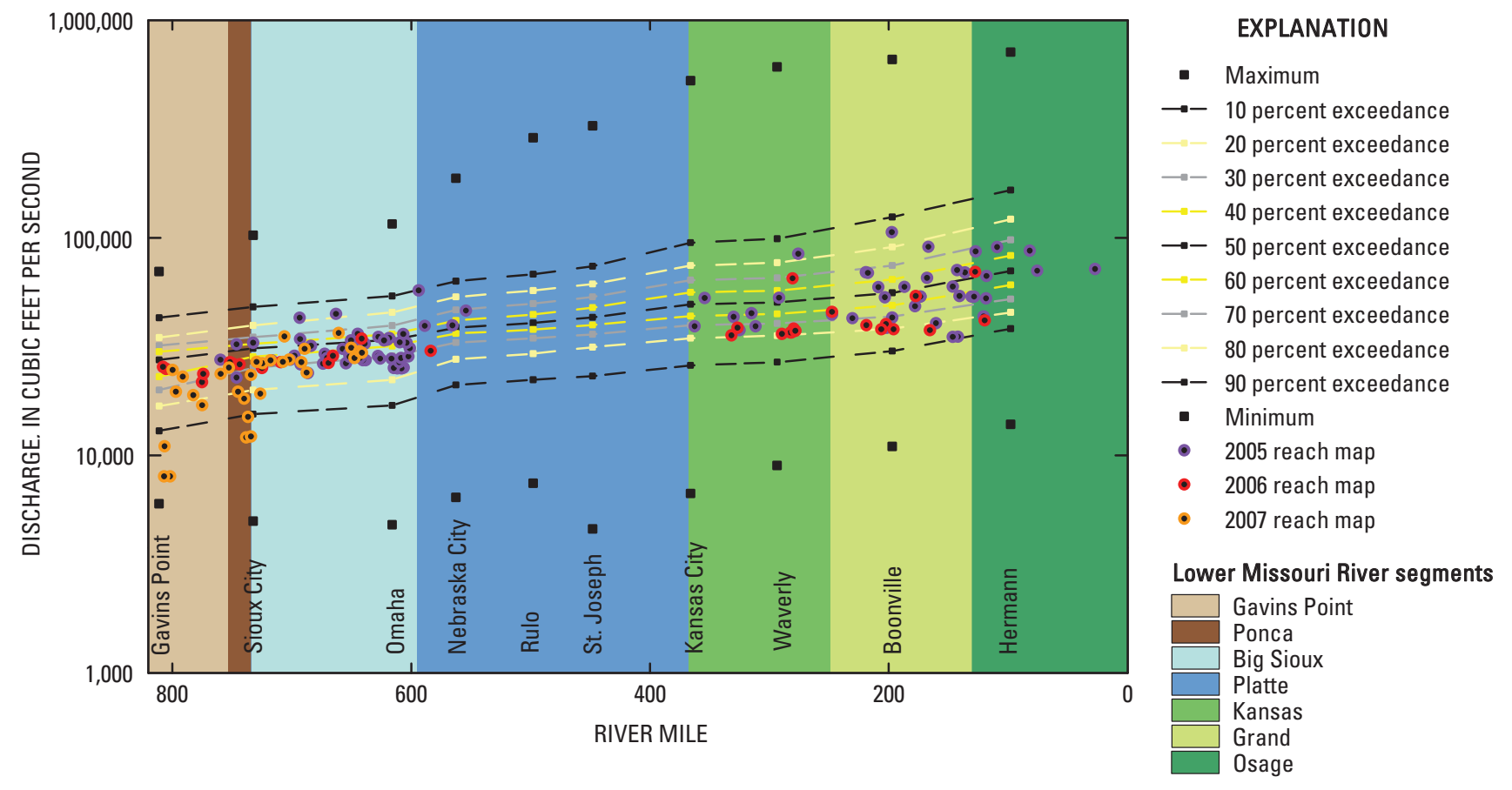

Figure 4. Plot of discharges on reach mapping dates in the context of flow exceedance data for the Lower Missouri River, based on daily discharge records. Flow exceedances were computed for Missouri River gages with records from 1967 to 2008 . From upstream to downstream, the gages are: Gavins Point Dam (U.S. Army Corps of Engineers), Sioux City (USGS streamflow-gaging station ID 6486000), Omaha (USGS 6610000), Nebraska City (USGS 6807000), Rulo (USGS 6813500), St. Joseph (USGS 6818000), Kansas City (USGS 6893000), Waverly (USGS 6895500), Boonville (USGS 6909000), and Hermann (USGS 6934500). 
substantial discharges to the Lower Missouri River; flow releases from the dam were very low during this period to compensate for flows from the tributaries.

The spatial distribution of maps along the length of the Lower Missouri River is a byproduct of a number of factors including the sampling design used in the telemetry studies, the movement of telemetered sturgeon, tracking search effort, and mapping effort. The distribution of telemetry relocations and reach maps at this broad scale does not indicate regional patterns of habitat selection. For example, the Platte segment is especially underrepresented in terms relocations and the number of maps, but this is primarily a result of the upstreamdownstream structure of the study design, and not necessarily because of the relative use of that segment by sturgeon.

\section{Descriptions of Specific Map Types}

Primary maps were generated directly from boatcollected hydroacoustic data (Reuter and others, 2008), and derived maps were computed from the primary maps. The three types of primary maps are depth, depth-averaged velocity, and substrate. These maps are based on hydroacoustic data from a longitudinal profile and a set of cross-sections spaced 15 to 40 meters apart. Raw datasets were processed according to methods outlined in Reuter and others (2008) to yield interpolated maps with a grid cell size of 5 meters. Maps represent areas navigable by the survey boat, generally where depths are greater than 0.6 meter.

Maps derived from primary maps or combinations of primary maps provide additional ways of looking at physical habitat conditions. These alternate views of the data offer some specific advantages over the raw, primary variables, even though they are not independent of the primary variables. For example, depth slope is less dependent on discharge than depth itself. Because the primary and derived variables are not independent, we considered issues of covariance and colinearity by exploring bivariate relations among primary and derived variables; examples are presented in the results.
Table 1 summarizes the map types, and figure 5 shows an example of each map type for a reach. The following descriptions provide additional detail:

Depth.-Most maps of depth were based on echo-sounder data collected with high-resolution, single-beam Hydrotrac echo sounders (Odom Hydrographic Systems, Inc., Baton Rouge, Louisiana). Some depth maps were based on data from an acoustic Doppler current profiler.

Depth slope.-Depth slope is effectively the topographic slope of the bed, in degrees. It is computed as the maximum slope of the depth grid within a moving 3 by 3 cell matrix (with 5 meter grid cells) using the ArcGIS slope algorithm (Environmental Systems Research Institute, Redlands, California). Depth slope is nearly independent of discharge if the bed morphology is static.

Terrain classification.-We used a bathymetric terrain classification approach to visualize major channel features. This technique is based on the concepts of the Topographic Position Index and the Benthic Terrain Modeler (Weiss, 2001; Lundblad and others, 2006); it uses measures of relative depth and slope to classify the channel into crests (bars), depressions (thalweg and deep holes), slopes, and flat areas (fig. D13 in Jacobson and others, 2007). Relative depth is computed as the difference between the depth at each grid cell and the average depth within an area defined by an annulus (two concentric circles) surrounding the grid cell. We used the following parameters: horizontal radii for the annulus of 25 and 250 meters; the vertical threshold used to differentiate crests/depressions from flat/sloped areas as 0.5 meter; and the slope threshold that differentiates flat from sloped areas as 5 degrees.

Generalized substrate.-Maps of substrate are based on an interpretation of data from a RoxAnn instrument (Marine Microsystems and Sonavision, Ltd., Aberdeen, United Kingdom) in combination with spatial data regarding the location of engineered structures and bedrock (Reuter and others, 2008). These maps are general indicators of substrate characteristics. Two categories were derived from RoxAnn data alone; these categories are (1) sand (generally dunes) and (2) a

Table 1. Map types and sources.

\begin{tabular}{|c|c|c|c|c|}
\hline Map type & Source & $\begin{array}{l}\text { Primary or } \\
\text { derived }\end{array}$ & $\begin{array}{c}\text { Variable } \\
\text { type }\end{array}$ & $\begin{array}{l}\text { Units used in this } \\
\text { report }\end{array}$ \\
\hline Depth & $\begin{array}{l}\text { Echo sounder or depth returns from acoustic Doppler current profiler } \\
\quad \text { (Reuter and others, 2008) }\end{array}$ & Primary & Continuous & Meters. \\
\hline Terrain classification & From depth, using methods in Jacobson and others (2007) & Derived & Discrete & -- \\
\hline Velocity gradient & From depth-averaged velocity map, using ArcGIS slope command & Derived & Continuous & Percent per meter. \\
\hline Froude & From depth and depth-averaged velocity & Derived & Continuous & -- \\
\hline Shallow-water habitat & $\begin{array}{l}\text { From depth and depth-averaged velocity, using Biological Opinion } \\
\text { definition of shallow-water habitat, depth less than } 1.5 \text { meters, } \\
\text { velocity less than } 0.6 \text { meters per second }\end{array}$ & Derived & Discrete & -- \\
\hline
\end{tabular}



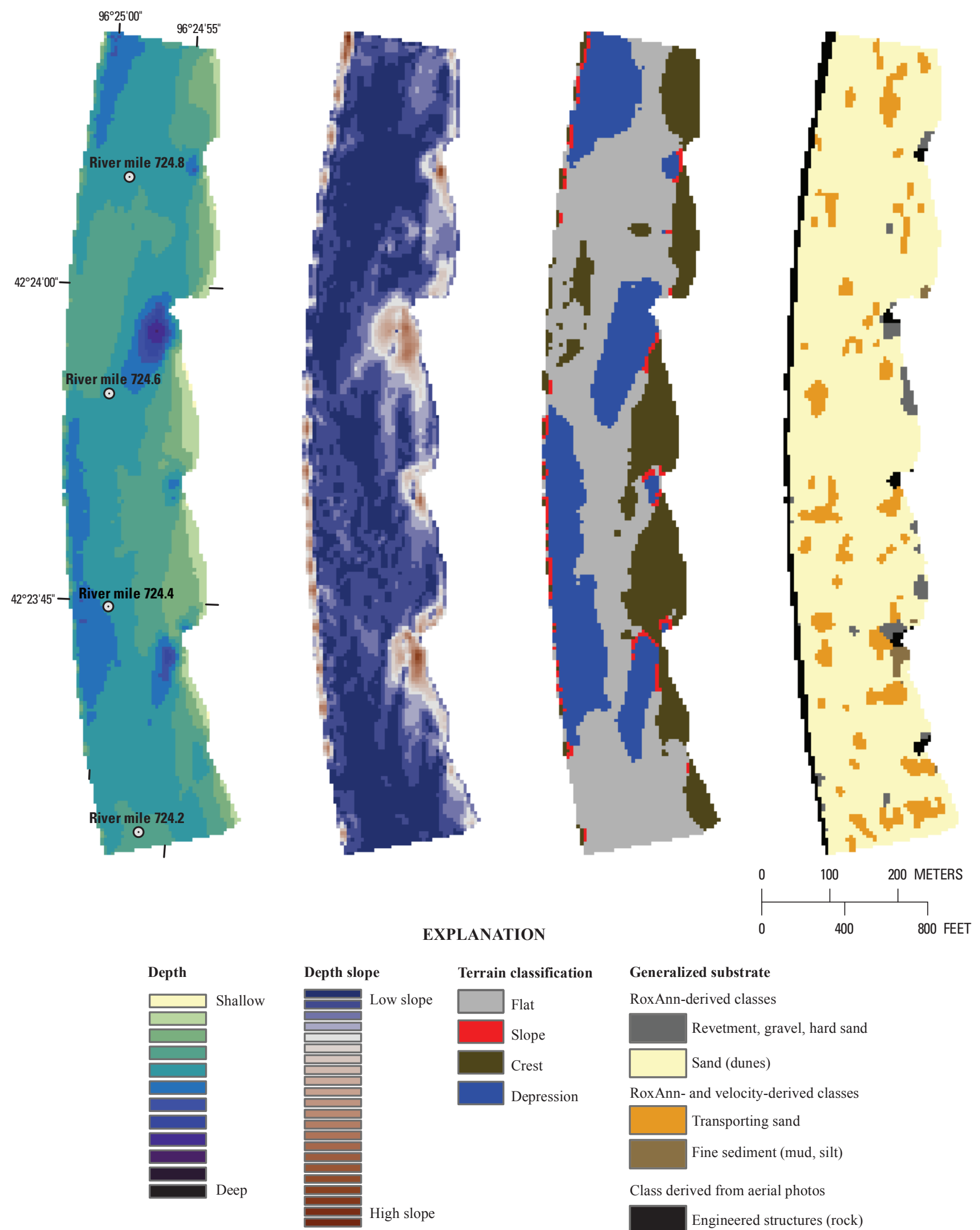

Generalized substrate RoxAnn-derived classes

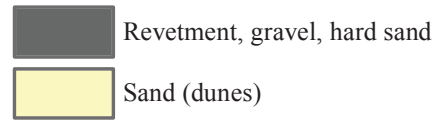

RoxAnn- and velocity-derived classes

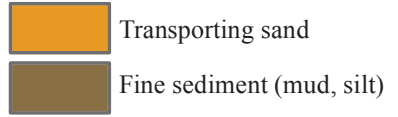

Class derived from aerial photos

Engineered structures (rock)

Figure 5. Maps of an example reach, with each type of primary and derived map illustrated: depth, depth slope (derived from depth), terrain classification (derived from depth), substrate, velocity, velocity gradient (derived from velocity), Froude number (derived from depth and velocity), and shallow-water habitat (derived from depth and velocity). 

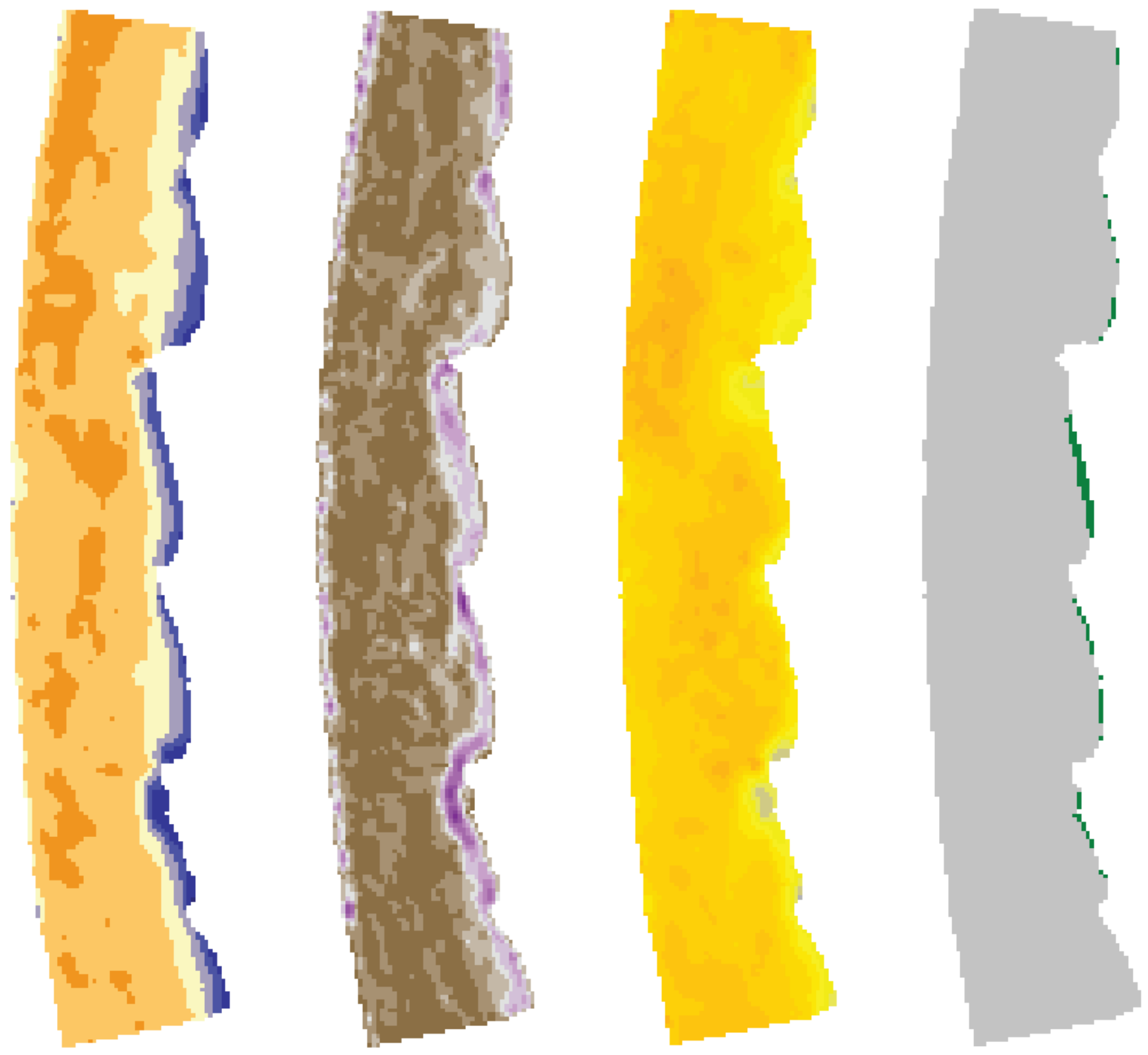

EXPLANATION

Depth-averaged velocity Gradient of depth-averaged velocity

Froude number
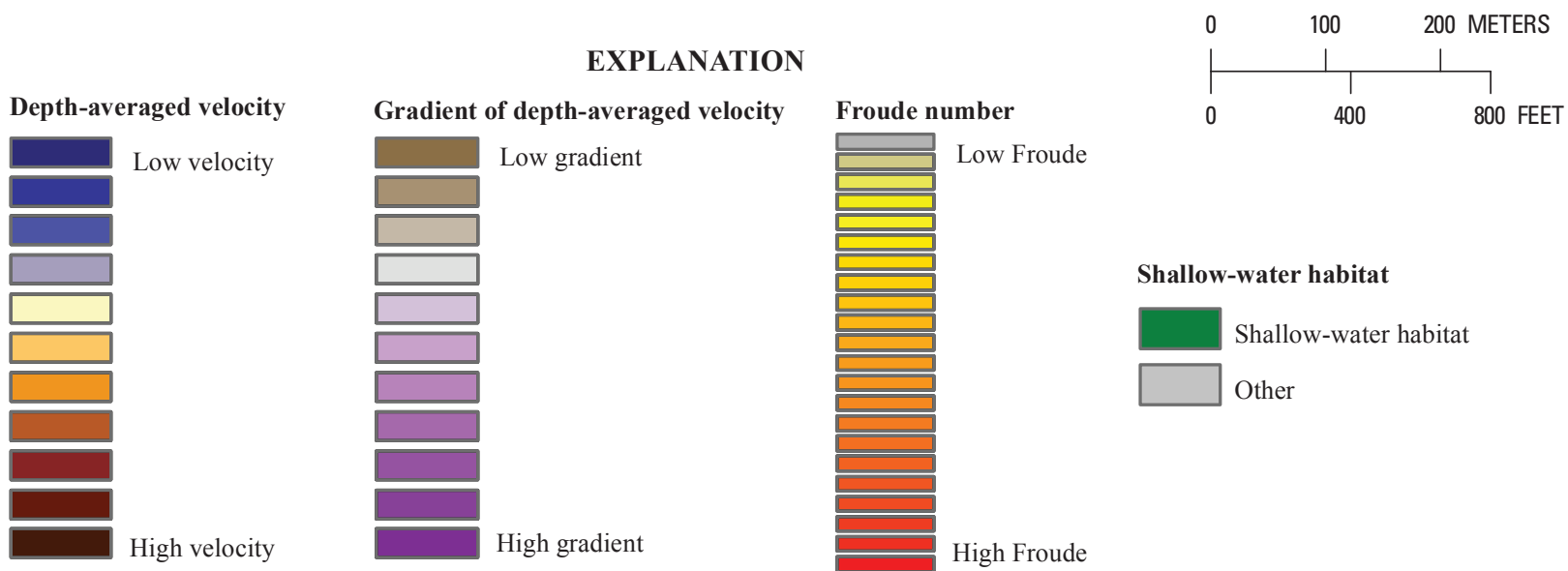

Shallow-water habitat

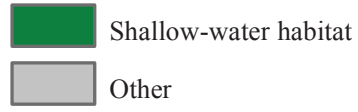

Figure 5. Maps of an example reach, with each type of primary and derived map illustrated: depth, depth slope (derived from depth), terrain classification (derived from depth), substrate, velocity, velocity gradient (derived from velocity), Froude number (derived from depth and velocity), and shallow-water habitat (derived from depth and velocity).-Continued 
grouping that includes revetment, gravel, and hard sand. RoxAnn data, in combination with velocity data, were used for the differentiation of two categories: (1) transporting sand (where velocities were high) and (2) fine sediment, including mud and silt (where velocities were low). Two classes were derived from geospatial data: (1) engineered structures (generally rock) and (2) bedrock (a class with very little representation).

Depth-averaged velocity - Maps of depth-averaged water velocity were based on data from acoustic Doppler current profilers (Teledyne RD Instruments, Poway, California). Depth-averaged values were used for two reasons. Sturgeon are generally benthic fish, but the position in the water column is not known with certainty for the relocation points. Secondly, near-bottom velocity data tend to be noisy because of turbulence, so meaningful maps of near-bottom velocities cannot be readily generated from available datasets. Depth-averaged velocities provide the best available information about the overall hydraulic environment. Throughout this report, the term "velocity" refers to depth-averaged velocity.

Velocity gradient.-Velocity gradient represents the amount of spatial change in velocity, in percent per meter, computed using the ArcGIS slope algorithm. (Thus, the maximum slope is determined from a 3 by 3 cell matrix of 5 meter grid cells.) Various studies have concluded that fish respond to velocity-derived variables, including vorticity (Crowder and Diplas, 2000, 2006; Yang and others, 2007) and total hydraulic strain (Nestler and others, 2008). The velocity gradient variable that we used is based on a more simplistic approach, but the resulting maps show strong correlations with the vorticity and strain variables (Jacobson and others, 2009b).

Froude number--Froude number is a dimensionless parameter derived from depth, velocity, and the gravitational constant. It is calculated as: Froude $=$ velocity $/ \sqrt{ }$ (gravitational constant * depth). Conceptually, Froude number represents how energetic the environment is; higher Froude number values correspond to higher energy environments (more kinetic energy relative to potential energy). Froude number commonly has been used in habitat characterization studies (for example, Yu and Peters, 1997; Reuter and others, 2003).

Shallow-water habitat.-The Missouri River Biological Opinion (U.S. Fish and Wildlife Service, 2000) defines shallow-water habitat as follows: depths are less than or equal to 1.5 meters and velocities are less than or equal to 0.6 meters per second. Shallow-water habitat maps are derived by reclassifying and combining depth and velocity maps to meet these criteria. The area of mapped shallow-water habitat is a minimum amount for each reach because maps include only parts of the reach navigable by the survey boat, generally where water depth exceeded 0.6 meters.

\section{Analysis Approach}

Analysis was based on an exploratory approach with three parts: (1) Exploration of the reach map data alone. We considered patterns and relations among physical variables, with an emphasis on longitudinal patterns along the Lower Missouri River. (2) Exploration of characteristics at sturgeon relocations in the context of available conditions in the reach. We investigated how the values of physical environmental variables at sturgeon relocations compare to the range of values in the surrounding reaches. The approach that we used considers only one variable at a time. (3) Exploration of patterns of habitat use, as identified in the previous step, in a map context. After identifying some relations between sturgeon relocations and the available environmental variables, we generated maps of selected habitat types. Each of these three parts is described in more detail in the following sections.

\section{Descriptive Statistics of Reach Maps}

The reach maps represent a sample of more than 20 percent of the length of the Lower Missouri River and are the most extensive set of maps available on the river with this level of detail. Descriptive statistics from these maps can be used to characterize longitudinal patterns of channel morphology and habitat complexity, although cataloging spatial variation in habitats was not the primary intended purpose of these maps. Instead, the maps were collected with the intention of assessing habitat availability for sturgeon at the reach scale. Thus, there are some caveats about how well these maps characterize habitat at the broadest scales. The maps represent a range of discharges determined by sturgeon relocations and, therefore, depict habitats over a range of flow exceedances. The maps also are distributed unevenly geographically; some locations were mapped more than once and some segments (especially the Platte segment) are poorly represented in the dataset. At the reach scale, the maps were constrained to include only areas that could be navigated by the survey boat. Nonetheless, robust patterns emerge from the descriptive statistics.

Reach geometry statistics.-The following summary statistics were used to characterize reach geometry: Reach wetted area was determined from the area of the polygon that encompassed all of the hydroacoustic data for the depth map. Reach length was determined from the length of an approximate center line passing through the reach. Reach mean width was computed as the area of the reach polygon divided by the reach length. The width is based only on mapped, wetted area; islands and emergent bars were ignored. Reach volume was computed as the sum of the depth grid cell values multiplied by the grid cell area (25 square meters). Reach mean wetted cross-sectional area was computed as the reach volume divided by the reach length. Note that some of the reach geometry statistics are biased estimates because they are based on the part of the reach that the boat could navigate and map (reach maps do not always represent 100 percent of wetted reach); Gavins Point segment reaches are particularly prone to err on the side of underestimating areas, widths, and volumes because of unmapped shallow areas. Unit length residence 
time was computed from the volume divided by the prevailing discharge divided by the reach length. Reach volumes (and thus residence times) are minimum estimates, especially in the Gavins Point segment. Prevailing discharge was estimated based on the nearest gages as described in Reuter and others (2008). Reach mean velocities were calculated as the mean of all grid cells in the depth-averaged velocity maps.

Histograms.-Univariate summaries included frequency data for each continuous variable (depth, depth slope, velocity, velocity gradient, and Froude number) for each reach. Reach histograms were pooled to generate composite histograms representing all of the mapped reaches in each segment. Histograms were normalized such that the area under the curve equals one.

Bivariate relations and correlation coefficients.-For each reach and for each pair of continuous variables, we considered bivariate relations by plotting scatter plots and computing linear correlation coefficients. A set of approximately 10,000 regularly spaced points were superimposed on each depth map, and values were extracted from the grid for each variable using bilinear interpolation from the surrounding grid cells to obtain an estimate of the value at each point. The bivariate plots and correlation coefficients were examined to assess degree of colinearity and to develop a better understanding of the relations of derived variables to primary variables.

\section{Relations of Sturgeon Relocations to Habitat Variables}

The analysis of sturgeon habitat selection is focused at the reach scale; that is, characteristics at sturgeon relocations are compared to the values available in the surrounding reach. This analysis uses all reach maps, random or nonrandom, and data from 3 years, 2005 through 2007.

\section{Qualifying Sturgeon Relocations: 7 Day and 10 Percent Discharge Criteria}

Most reach maps were made to target one particular sturgeon relocation. However, many maps have additional, nontargeted sturgeon relocations within their boundaries. If these opportunistic sturgeon relocations occurred near in time and at discharge conditions similar to those on the map date, then these sturgeon also were included in the analysis.

We took a conservative approach by restricting the analysis to relocations that had been documented within 7 days of the map date and within 10 percent of the discharge on the map date. We chose to limit the time frame to 7 days (either before or after the map date) because of recently developed understanding of rates and magnitude of geomorphic change in the Lower Missouri River by Elliott and others (2009). That study, based on channel-monitoring data from four reaches of the Missouri River during 2006 and 2007, demonstrated that substantial in-channel geomorphic change can occur on a month-to-month time scale; periods of shorter duration were not documented in the study. The discharge threshold of 10 percent was the same as that used to decide whether to map a targeted relocation. Discharge was estimated based on data from the nearest mainstem gage or a combination of mainstem and tributary gages, using methods described in Reuter and others (2008).

These criteria did eliminate some sturgeon relocations that were originally targeted for mapping. Ideal discharge ranges were not always met in the field, and the time lag between relocation and mapping was greater than 7 days in some cases. However, even with the loss of some targeted sturgeon from the analysis, the number of qualifying relocations ultimately increased relative to the group of directly targeted sturgeon relocations. The resulting dataset includes 112 maps with a total of 378 sturgeon relocations.

Uncertainty in determining a habitat value at a sturgeon relocation arises from a number of sources. Horizontal positions from differential GPS (DGPS) are accurate to less than 1 meter; both sturgeon relocations and hydroacoustic map data were collected with DGPS. Relocation position uncertainty also is related to how precisely the boat can be positioned over the sturgeon when the data point is logged; total horizontal uncertainty for positions is estimated to be approximately 2 meters, less than the scale of map grid cells (5 meters). Uncertainty in map data is largely related to data interpolation. Values are best constrained near the transects where data were collected, and uncertainty generally increases with distance from the nearest transect. Estimates from interpolation with ordinary kriging suggest that depth uncertainty is generally less than 1.5 meters and velocity uncertainty is generally less than 0.4 meters per second. However, even along a transect, features at a scale smaller than the 5 meter grid cells cannot be resolved (small- to moderate-size dunes, for example). Dynamically migrating sand dunes have the potential to alter benthic microhabitats and velocity distributions. Dune migration rates documented by Elliott and others (2009) ranged up to 3 meters per day, resulting in background variability of hydraulics and substrate characteristics at the dune scale. The uncertainty estimates from kriging do not incorporate potential changes resulting from differences in discharge between the time of relocation and the time of mapping. Discharge estimates also include uncertainty, both from the discharge estimation process at the gaging station and from the use of the gage data to estimate values at locations distant from gaging stations. Discharges are best constrained near USGS streamflow-gaging stations and at times when discharges are stable, because of the use of daily average discharge data. We used conservative date and discharge ranges to minimize data uncertainty. Furthermore, we took the approach of considering values at relocations relative to the context of the surrounding map. Use of this approach helps to minimize the uncertainty of values that tend to show a systematic change with discharge, such as depth. 


\section{Approaches for Assessment of Sturgeon Habitat Selection}

The challenge for analyzing the sturgeon relocation and reach map data in the context of habitat selection lies in the fact that each sturgeon relocation should be considered in the context of habitat availability just in the surrounding reach, but most reach maps contain only one or a few relocation points - generally too few to be conclusive on their own. Thus, the results from individual reaches must be combined in a meaningful way. We took two complementary approaches to the assessment of habitat selection for continuous variables: an approach involving absolute variable values and an approach involving relative variable values. Assessment of habitat selection for categorical variables was similar to the absolute approach for continuous variables. All exploratory analyses were performed in a univariate context. The following sections describe each approach.

Continuous variables in terms of absolute variable values-For each continuous variable (depth, velocity, depth slope, velocity gradient, and Froude number), the absolute approach involved compiling: (1) composite histograms for groups of reach maps, and (2) composite histograms for values at sturgeon relocations from corresponding groups of maps. The histograms were normalized and plotted together. For a given histogram bin, the relative height of the histogram bar representing habitat availability compared to the height of the bar representing sturgeon relocations suggests whether the values represented by that bin were selected or avoided. For example, if the proportion of relocations exceeds the proportion of available habitat for a given bin, this suggests selection. Because multiple maps were pooled for these comparisons, a potential pitfall of this approach is that the sturgeon relocation values are compared to composite distributions from reach maps, and the distribution and range of values of the composite map histograms may differ somewhat from the distribution or range of values that each specific sturgeon could actually select - that is, the habitat values in the reach-scale vicinity of the sturgeon. To minimize this issue, we computed the histograms by geomorphically similar river sections. In spite of this limitation, we feel this approach is valuable because it is fairly intuitive, and because the results are in terms of absolute numeric values for the variables in question.

We took these results a step further by calculating Ivlev's selectivity coefficients to quantify the strength of selection for habitat values (Manly and others, 2002). Selectivity coefficients are calculated as:

$$
E_{i}=\left(o_{i}-\pi_{i}\right) /\left(o_{i}+\pi_{i}\right)
$$

where:

$E_{i} \quad$ is the selectivity coefficient for resource unit I (from -1 to +1 ),

$o_{i} \quad$ is the sampled proportion of used units, and

$\pi_{i} \quad$ is the sampled proportion of available units.
Values of the selectivity coefficient near zero indicate habitat is used in proportion to its availability. Positive coefficient values indicate habitat selection, whereas negative coefficient values indicate avoidance. Although these coefficients do not indicate a probability of sturgeon occurrence in the habitat unit, they document the strength of selection among a range of values. Bins with no relocations receive a -1 selectivity coefficient even if the amount of available habitat area is very small, so selectivity coefficients computed from such bins should be interpreted with caution.

Continuous variables in terms of relative variable values using a decile classification approach.-The relative approach used to explore sturgeon selection of habitat with respect to continuous variables (depth, velocity, depth slope, velocity gradient, and Froude number) in a univariate context involved computing the decile distribution for each map of the continuous variable type. This method divides the range of the variables such that each interval represents one-tenth of the mapped area (fig. 6). The value at each sturgeon relocation is considered in the context of the decile values for the respective reach to determine within which decile range the sturgeon relocation value falls. This is a measure of used habitat compared to available habitat in the reach. Using this approach, the value at a sturgeon relocation is compared to the range of values available locally. For groups of sturgeon relocations from collections of reach maps, the distribution of the sturgeon decile values can provide insight into whether sturgeon nonrandomly select habitats from among the range of values available to them. Because the decile zones are of equal area, this is a straightforward assessment of sturgeon habitat selection in the context of univariate data. If sturgeon are not responding to a given variable, either directly or indirectly, then we would expect similar numbers of relocations to be found in each decile range.

We have compiled the results by river section and by species, sex, and reproductive condition. In addition, for reproductive female shovelnose sturgeon, we have further compiled the data by year, by month of the year, and by discharge range. However, we have not assessed how relocations may have been influenced by antecedent hydrologic, hydraulic, or temperature conditions, nor have we accounted for sturgeon behavior at the time of relocation. These are possibilities for future analyses.

Categorical variables.-For each categorical variable (substrate, terrain classification, and shallow-water habitat), the available area of each category was summarized for each reach map. In addition, the category at the location of each qualifying sturgeon relocation was determined. Within geomorphically similar river sections, we computed the proportion of available habitat in each category, as well as the proportion of sturgeon found within each category. These values were used to compute Ivlev's selectivity coefficients. This approach compares the composite distribution of sturgeon relocations with the composite distribution of habitat values among many reaches. Within river sections, the broad similarity of the proportional availability of categorical values contributes to the validity of this approach. 


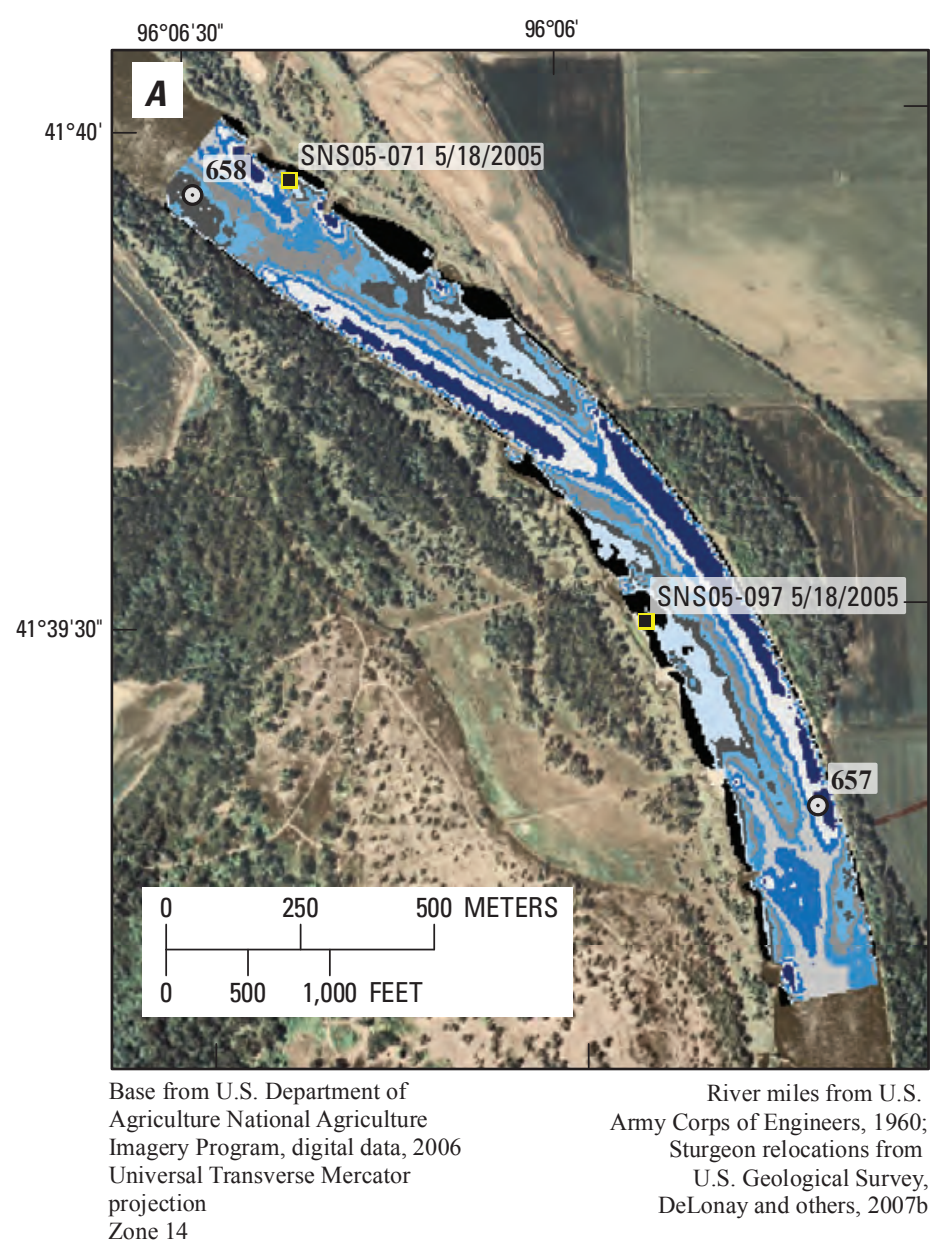

\section{EXPLANATION}

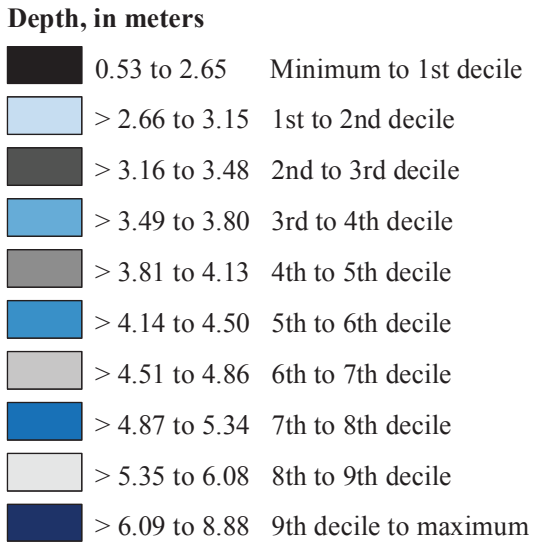

SNS07-141 5/22/2007

- Sturgeon relocation-

Label shows identification code of tagged sturgeon and the relocation date

$0^{514}$ River-mile markerNumber is distance upstream from the junction with the Mississippi River, in miles

\section{B}

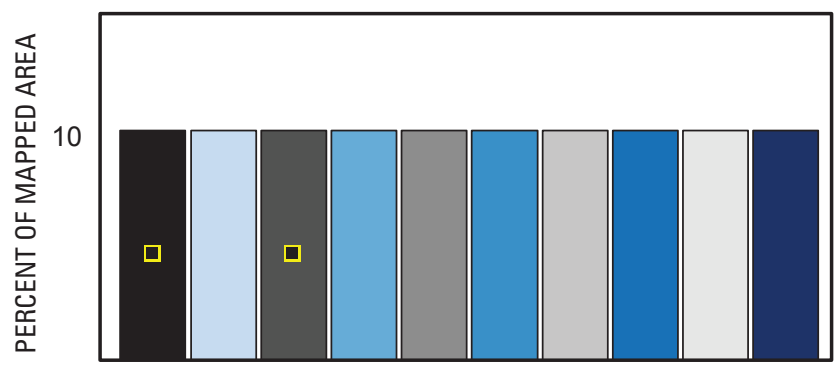

DECILE CLASS

Figure 6. Illustration of the approach used to characterize sturgeon relocations by decile range of habitat used. $A$, Depth map color coded by decile ranges with two qualifying sturgeon relocation. $B$, Plot showing that each decile range represents an equal area. In this case, one sturgeon relocation fell in the first decile and one in the third.

\section{Inferred Patterns of Habitat Use in a Map Context}

The decile analysis yielded results that indicate that habitat use by sturgeon is non-uniform in the Lower Missouri River. We explored the spatial distribution of the ranges of values that sturgeon tended to select for three variables (depth slope, velocity gradient, and Froude number) to address some basic questions: Where do these values occur? How do the different variables interact in a spatial context? How do the patterns differ by river section? In the approach that we took, we reclassified maps of each continuous variable such that a "1" represented the 2 most selected deciles, and a " 0 " represented the remainder of the deciles. After reclassifying each individual variable, we combined the maps by adding them together. In the resulting maps, each grid cell has a value from 0 to 3 , representing the number of variables that fall within the range that sturgeon showed the greatest tendency to select. Finally, to assess whether these zones might represent a more general predictor of habitats that are selected by sturgeon, we considered where the general population of sturgeon relocations fell on the reclassified maps. All relocations falling on the maps were considered, as long as the relocations and the maps were from the same year.

The following reasons justify the decision to include all sturgeon relocations from the same year (rather than just those within 7 days and 10 percent discharge of the map): (1) For reaches that were mapped more than once, observations suggest that the spatial patterns of the mapped selection zones show some degree of persistence. For example, in some areas, selection zones tend to be associated with the edge of the channel, a pattern that appears relatively robust within the context of the observed amount of morphologic change. (2) Use of all relocations from the same year substantially increases the sample size of relocations associated with maps; notably, this means that many more relocations (sample size $=$ 2,013 ) are being used to test the selection model relative to the number of relocations (sample size $=378$ ) that were used to develop the selection model. 


\section{Geomorphic Characterization of the Lower Missouri River Based on Reach Maps}

The reach maps provide insight into the geomorphic character and longitudinal variability of the Lower Missouri River. This section presents several summaries of reach characteristics. As a part of the data exploration, we address the question of how best to group similar parts of the river; are there natural groupings of data that suggest different parts of the river have distinct habitat structures? We approached this analysis with the working hypothesis that reaches within segments - defined primarily by major tributary junctions (fig. 1) -would share similarities (Frissell and others, 1986; Benda and others, 2004). Other factors that could influence longitudinal patterns of habitat quantity and quality include engineering structures, flow regime, and physiographic provinces. Qualitative patterns emerge from the reach summary data presented here.

In the first group of summary plots, reach geometry characteristics and other summary data are plotted against river mile (fig. 7). In these plots, each reach stands for itself, and no assumptions are made about how to group parts of the river with like characteristics. Plotted points represent all mapped discharges, regardless of flow exceedance. Several notable patterns can be discerned from figure 7. Discharge and wetted cross-sectional area show an overall increase in the downstream direction. However, other variables that commonly increase in a downstream direction under natural river conditions show more complex patterns on the Lower Missouri River; velocity and width are examples. For similar discharges, mean reach velocities are highest in the Big Sioux and Platte segments, where the widths are also the narrowest. Mean reach depth averages more than 4 meters throughout the navigable parts of the river, with generally shallower mean depths (less than 3 meters) upstream from Sioux City, Iowa.

A schematic summary of reach geometry data averaged by segment is presented in figure 8 . Mean width, depth, and velocity were computed from the reaches located within each segment. In this plot, box length is scaled with mean segment width and box height is scaled with mean segment depth (with no vertical exaggeration); the arrows are scaled with mean velocity. This graphic illustrates that, on average, the Gavins Point and Ponca segments are wide, relatively shallow, and have relatively low velocities. The Big Sioux and Platte segments are narrow and deep, with relatively high velocities. The Kansas, Grand, and Osage segments have mean depths and velocities similar to each other, and mean segment widths progressively increase in a downstream direction.

Composite histograms provide another summary of data at the segment scale (fig. 9). The composite depth histograms for the Gavins Point and Ponca segments are both skewed to the right. The composite depth histograms for the Big Sioux and Platte segments are both relatively symmetrical. The Kansas, Grand, and Osage segment composite depth histograms are complex, with a subpopulation of relatively shallow depths associated with areas on channel margins and behind wing dikes. Similar to depth, three distinct sets of velocity histograms are apparent: The Gavins Point and Ponca composite velocity histograms are roughly symmetrical. The Big Sioux and Platte composite velocity histograms are skewed left. The Kansas, Grand, and Osage composite velocity histograms show a more complex, shape, heavily skewed left and containing secondary modes.

To simplify analysis, we grouped the seven Lower Missouri River segments into three major river sections on the basis of the similar groupings of habitat-variable distributions (fig. 9), mean widths (fig. 8), and mean velocities (fig. 8). From upstream to downstream, these are referred to as the Minimally Engineered, the Upstream Channelized, and the Downstream Channelized sections. Because of the gap in relocations and maps between the upper Platte segment and Kansas City, we cannot precisely determine the location or abruptness of the change from the Upstream Channelized to the Downstream Channelized section based on the map data. Generally, however, these river sections correspond to parts of the river that are engineered and managed in different ways. Typical reaches document habitat characteristics of the three river sections (figs. 10-12). For each of these example reaches, figures also show the bivariate relations of the continuous variables.

The bivariate relations among continuous variables (table 2, figs. 10-12) yield additional insight into the geomorphic and hydraulic structure of the mapped reaches. Variation exists among the correlation coefficients from reach to reach and section to section, but some generalizations can be made that apply to the entire Lower Missouri River. On a point by point basis, depth and velocity tend to be positively correlated; higher velocities tend to be associated with greater depths. Within reaches, the exceptions occur in association with deep scour holes that have low velocity; deep, slow scours are particularly prevalent in the Downstream Channelized section of river. The correlation of depth and velocity in the Lower Missouri River contrasts with depth-velocity relations in many smaller rivers and streams where the shallow riffle environments tend to have high velocities, and pools tend to have low velocities at moderate discharge (Rabeni and Jacobson, 1993). Depth slope and velocity gradient sometimes also exhibit a positive correlation. To the extent that depth and velocity covary, it is reasonable that their derivatives - depth slope and velocity gradient - would covary as well. A third variable pair that shows relatively strong positive correlations is velocity and Froude number. Froude number on the Missouri River tends to be relatively low, less than 0.3. Conditions that produce high Froude numbers (shallow depth and high velocity) tend not to occur on the Lower Missouri River. Under prevailing conditions, Froude number is strongly correlated with velocity but not with depth. Correlations between other variable pairs are weak or inconsistent (table 2). Recognition of the relations among physical variables may be useful in assessing responses of biota to the physical environment. 

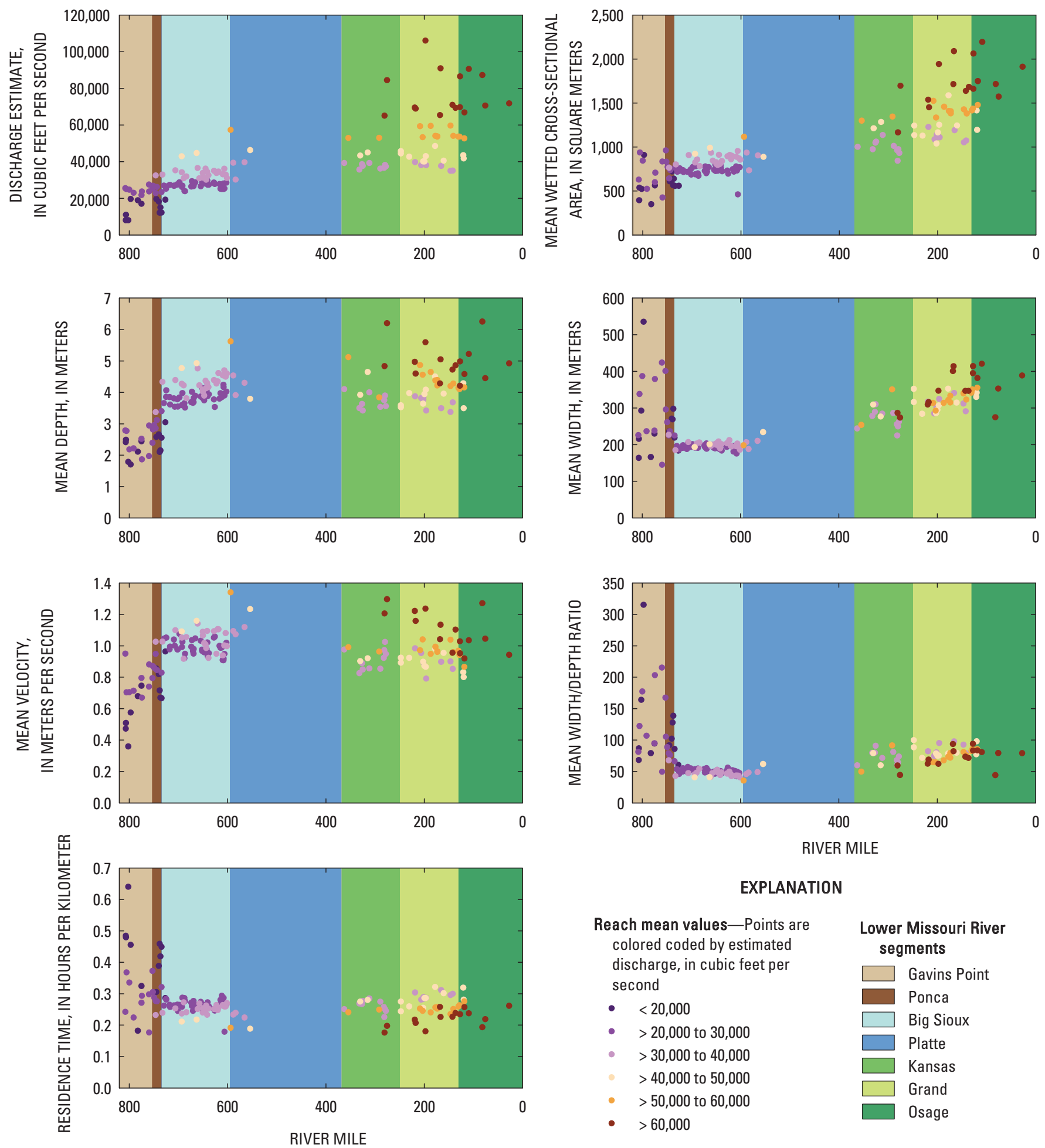

\section{EXPLANATION}

Reach mean values-Points are colored coded by estimated discharge, in cubic feet per second

- $\quad<20,000$

- $>20,000$ to 30,000

- $\quad>30,000$ to 40,000

$>40,000$ to 50,000

- $>50,000$ to 60,000

- $>60,000$
Lower Missouri River segments

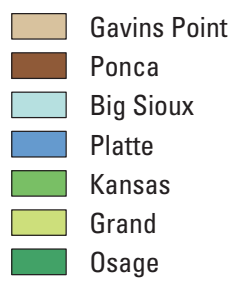

Figure 7. Plots of reach geometry and related statistics by river mile. Each point represents a reach. For reference, the segments are shaded in the background of the plot. Data values were omitted for the map on May 21, 2007, near river mile 759.6 because the map represents only a side channel. 
Gavins Point segment (based on 13 reaches)

Mean depth $=2.2 \mathrm{~m}$, width $=300 \mathrm{~m}$, velocity $=0.7 \mathrm{~m} / \mathrm{s} \longrightarrow$

Ponca segment (based on 10 reaches)

Mean depth $=2.7 \mathrm{~m}$, width $=270 \mathrm{~m}$, velocity $=0.8 \mathrm{~m} / \mathrm{s} \longrightarrow$

Big Sioux segment (based on 65 reaches)
Mean depth $=4.0 \mathrm{~m}$, width $=200 \mathrm{~m}$, velocity $=1.0 \mathrm{~m} / \mathrm{s}$

Platte segment (based on 5 reaches)

Mean depth $=4.4 \mathrm{~m}$, width $=210 \mathrm{~m}$, velocity $=1.2 \mathrm{~m} / \mathrm{s}$

Kansas segment (based on 16 reaches)

Mean depth $=4.1 \mathrm{~m}$, width $=280 \mathrm{~m}$, velocity $=1.0 \mathrm{~m} / \mathrm{s}$

Grand segment (based on 32 reaches)

Mean depth $=4.2 \mathrm{~m}$, width $=320 \mathrm{~m}$, velocity $=1.0 \mathrm{~m} / \mathrm{s}$

Osage segment (based on 11 reaches)

Mean depth $=4.6 \mathrm{~m}$, width $=360 \mathrm{~m}$, velocity $=1.0 \mathrm{~m} / \mathrm{s}$

,

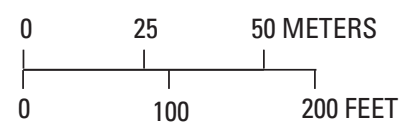

NOTE: Box dimensions are proportional to the width and depth of each segment, based on the mean of reach mean values. Arrows are proportional to the mean velocity of each segment. [m, meters; $\mathrm{m} / \mathrm{s}$, meters per second]

Figure 8. Schematic illustration of channel geometry and velocity characteristics, based on mean values by river segment. Widths, depths, and velocity values were calculated by taking the mean of the reach mean values in each segment.

Additional insight into the character of the Lower Missouri River comes from observations of channel change over time. The reach maps were not mapped with absolute elevation control because characterization of geomorphic change was not one of the goals of this portion of the sturgeon research project. However, some reaches were mapped on more than one occasion, and qualitative patterns of change shown by these repeat maps exhibit similarities to the geomorphic dynamics quantified in Elliott and others (2009). Figure 13 shows three examples of repeat mapping, with one reach per river section. The time interval between each pair of maps is approximately 1 year. The maps display classified bathymetry using the benthic terrain mapping technique, which has the advantage of highlighting the major features of the channel with relative insensitivity to discharge (Jacobson and others, 2009b). These examples of repeat mapping demonstrate the dynamic nature of the Lower Missouri River and illustrate differences in channel dynamics in various parts of the river.

The repeat mapping example from the Minimally Engineered section (fig. 13A, 13B) is located at Mulberry Bend (river mile 775), downstream from the James River junction. This reach shows some substantial changes in bar configuration and in the area navigable by the survey boat between the 2 years (although discharges were similar). Two additional reaches documented by Elliott and others (2009) in the Minimally Engineered section showed differing trends, with little change in the armored reach at Yankton, South Dakota, just 5 kilometers ( 3 miles) downstream from the dam, but substantial change in the Ponca segment at Kenslers Bend, when normalized for channel size.

The example from the Upstream Channelized section (fig $13 C, 13 D$ ) is near the junction with the Little Sioux River (river mile 669) and in close proximity to the reach that Elliott and others (2009) surveyed. As illustrated here, in the Upstream Channelized section the position of the thalweg often does not fall in the outer bend as defined by the engineered planform morphology. The repeat mapping example shows a shift in the location of bars and the depressions in a generally downstream direction. Elliott and others (2009) documented change of considerable magnitude, including shifts in the location of the thalweg from one bank to another over the course of a year.

The repeat mapping example from the Downstream Channelized section (fig. 13E, 13F) is in the Grand segment upstream from Lisbon Bottom. Although this reach was mapped at two different discharges and over a year apart, the major morphologic features of the reach show little change. The thalweg and bar positions are very stable, and the thalweg position corresponds to the outer bend of the river planform. Although change did occur, the overall stability of channel features is consistent with the surveys of Elliott and others (2009) in the Downstream Channelized section. 

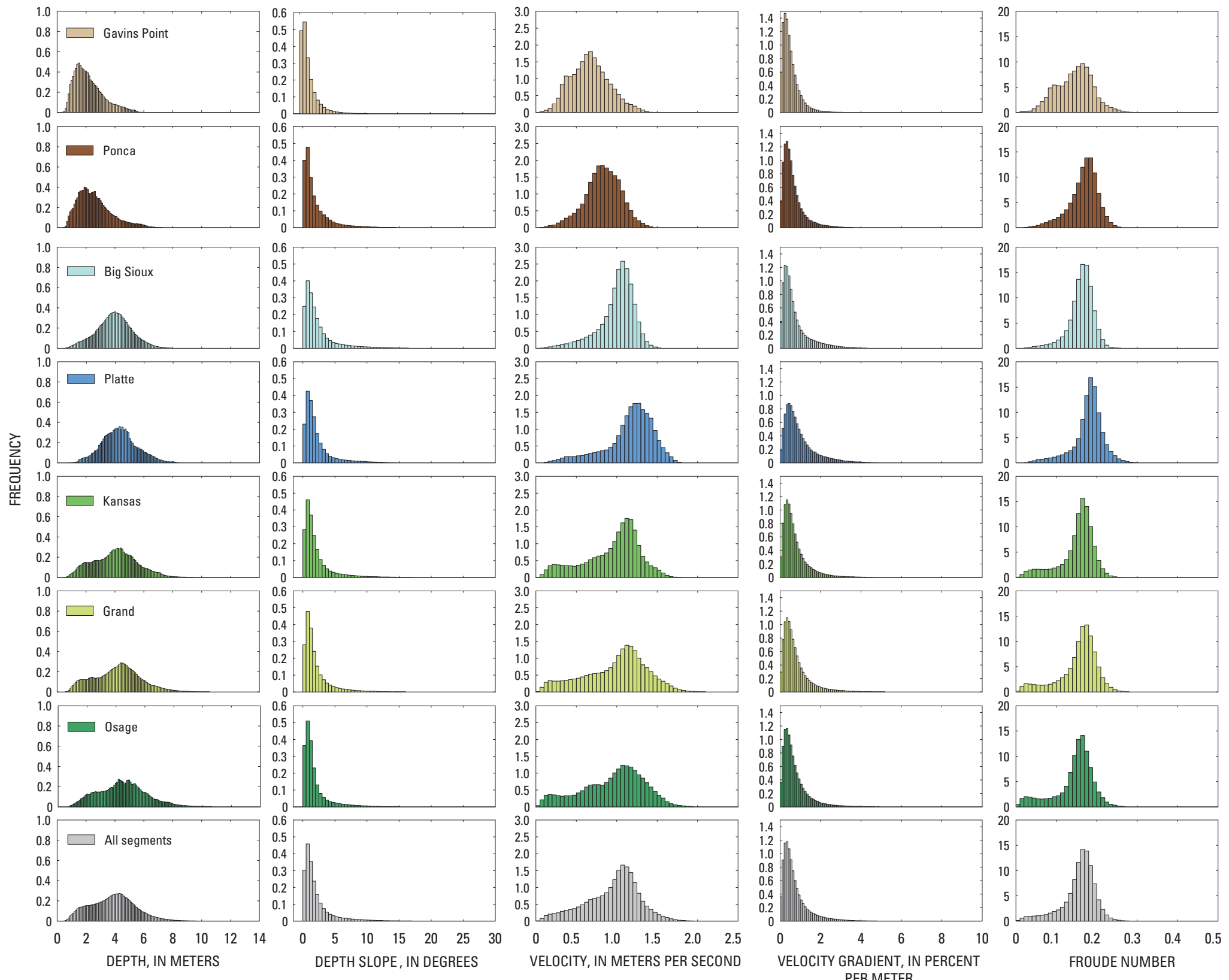

Figure 9. Composite histograms by river segment for depth, depth slope, velocity, velocity gradient, and Froude number. 


\section{Descriptions of Lower Missouri River Sections}

Observations from the reach maps suggest that the engineering framework of the Lower Missouri River is of overarching importance in determining habitat patterns; similarly engineered and managed sections of river tend to share similar morphologies and characteristics. Habitat controls exerted by physiographic constraints or changes in flow regime at major tributaries are less apparent.

An understanding of the geomorphic and hydrologic framework of the Lower Missouri River provides important context for interpretation of sturgeon relocations. Therefore, before addressing the results from the sturgeon data, we offer the following broad descriptions of the major sections of the Lower Missouri River, based on summary data from the mapped reaches and from published research. It is important to note that present-day (2008) descriptions of Missouri River habitats capture a synoptic view of a river system that is undergoing substantial re-engineering to support ecosystem recovery (U.S. Fish and Wildlife Service, 2000; U.S. Army Corps of Engineers, 2003; U.S. Fish and Wildlife Service, 2003; Jacobson and others, 2009a).

\section{Minimally Engineered Section (Gavins Point and Ponca Segments)}

The Missouri River is not maintained for commercial navigation from Gavins Point Dam to Sioux City, Iowa (fig. 1). From a morphologic standpoint, this is the least altered section of the Lower Missouri River and the closest to a reference condition. This is especially true upstream from Ponca State Park, where the river is under the jurisdiction of the National Park Service as the Missouri National Recreational River. There, much of the channel is multithreaded with sand bars, vegetated islands, and eroding banks, though banks have been stabilized with revetment in places (Elliott
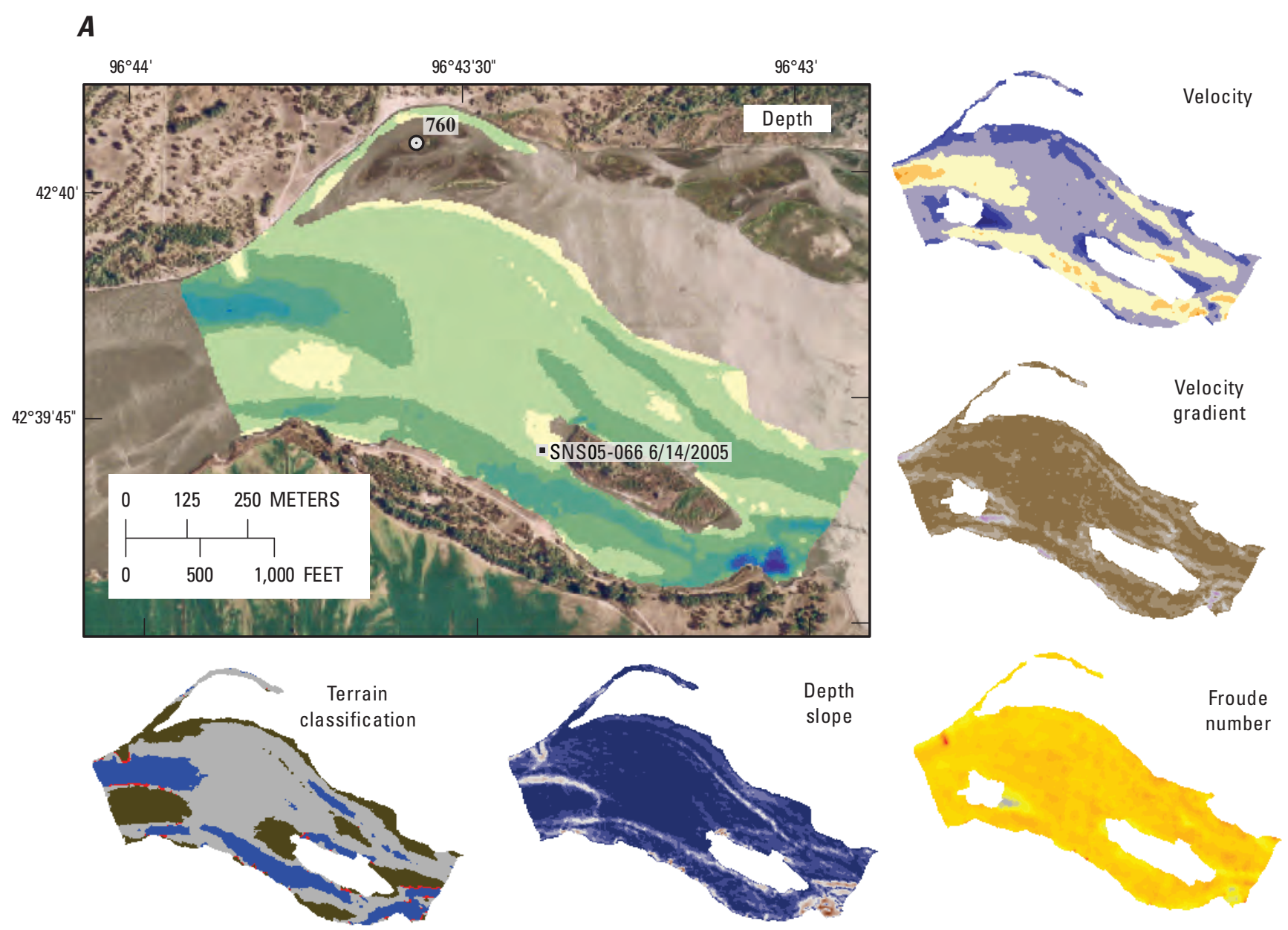

Base from U.S. Department of Agriculture National Agriculture Imagery Program, digital data, 2006 Universal Transverse Mercator projection

River miles (1960) from U.S. Army Corps of Engineers; Sturgeon relocations from U.S. Geological Survey, Zone 14 DeLonay and others, 2007b; Aaron J. DeLonay, unpub. data, 2008

Figure 10. Example reach from the Minimally Engineered section, mapped on June 15, 2005, in the vicinity of river mile 760. $A$, Maps are shown for each of the continuous variable and the terrain classification. $B$, Scatter plots illustrate relations among the continuous variables. 


\section{EXPLANATION}

Depth, in meters Terrain classification

\begin{tabular}{|c|c|}
\hline$\leq 1$ & Flat \\
\hline$>1$ to 2 & Slope \\
\hline$>2$ to 3 & Crest \\
\hline$>3$ to 4 & Depression \\
\hline$>4$ to 5 & \\
\hline$>5$ to 6 & \\
\hline$>6$ to 7 & \\
\hline$>7$ to 8 & \\
\hline$>8$ to 10 & \\
\hline$>10$ to 12 & \\
\hline$>12$ to 14 & \\
\hline$>14$ & \\
\hline
\end{tabular}

SNS07-141 5/22/2007

- Sturgeon relocationLabel shows identification code of tagged sturgeon

514 and the relocation date

$\odot$ River-mile marker-

Number is distance upstream

from the junction with the

Mississippi River, in miles
Depth slope,

0 to

$>1$ to 2

$>2$ to 3

$>3$ to 4

$>4$ to 5

$>5$ to 6

$>6$ to 7

$>7$ to 8

$>8$ to 9

$>9$ to 10

$>10$ to 11

$>11$ to 12

$>12$ to 13

$>13$ to 14

$>14$ to 15

$>15$ to 16

$>16$ to 17

$>17$ to 18

$>18$ to 19

$>19$ to 20

$>20$ to 21

$>21$ to 22
Depth-averaged velocity, Velocity gradient, Froude number in meters per second

in percent per meter
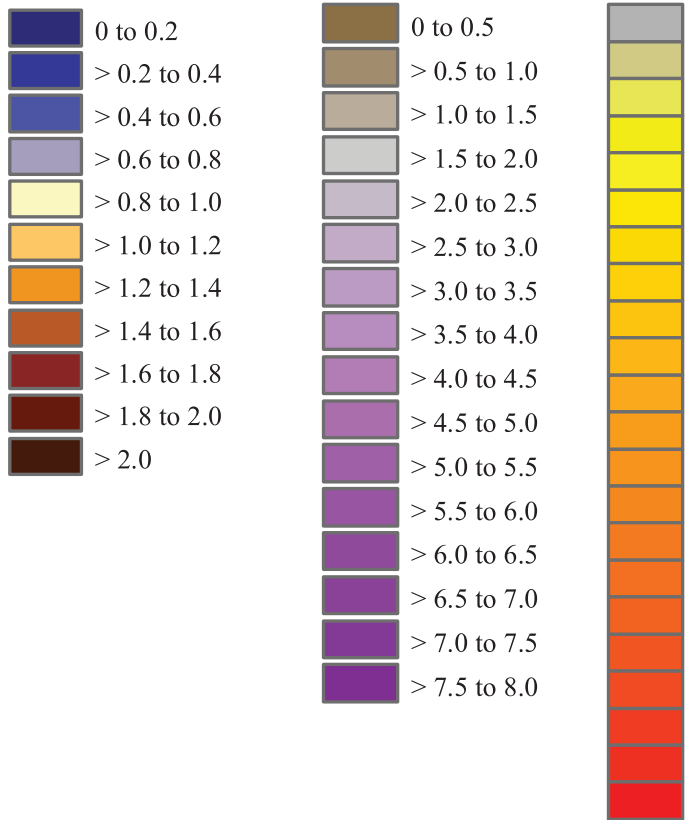

0 to 0.04

$>0.04$ to 0.06

$>0.06$ to 0.08

$>0.08$ to 0.10

$>0.10$ to 0.12

$>0.12$ to 0.14

$>0.14$ to 0.16

$>0.16$ to 0.18

$>0.18$ to 0.20

$>0.20$ to 0.22

$>0.22$ to 0.24

$>0.24$ to 0.26

$>0.26$ to 0.28

$>0.28$ to 0.30

$>0.30$ to 0.32

$>0.32$ to 0.34

$>0.34$ to 0.36

$>0.36$ to 0.38

$>0.38$ to 0.40

$>0.40$ to 0.42

$>0.42$ to 0.44

$>0.44$ to 0.46

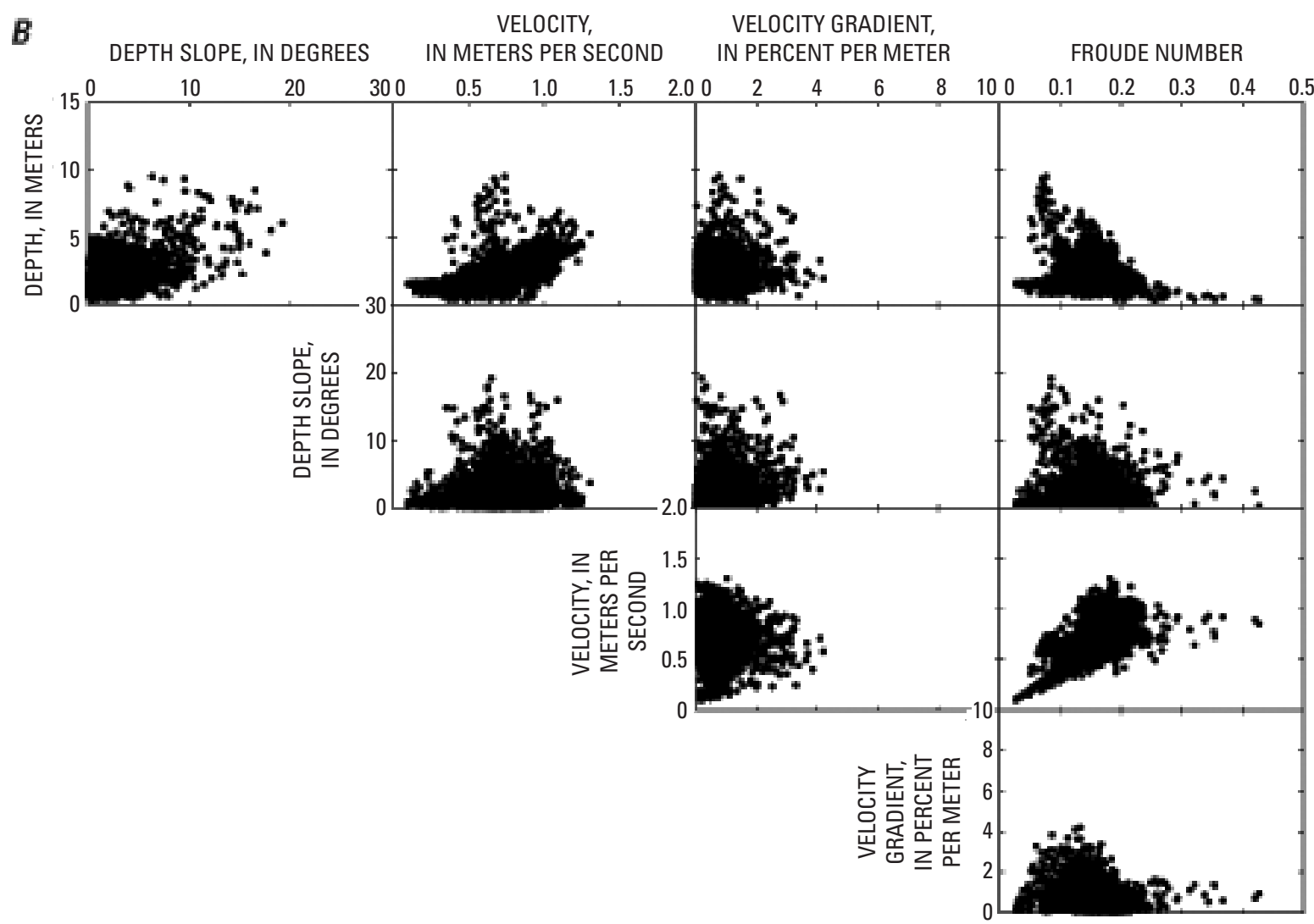

Figure 10. Example reach from the Minimally Engineered section, mapped on June 15, 2005, in the vicinity of river mile 760 . $A$, Maps are shown for each of the continuous variable and the terrain classification. $B$, Scatter plots illustrate relations among the continuous variables.-Continued 


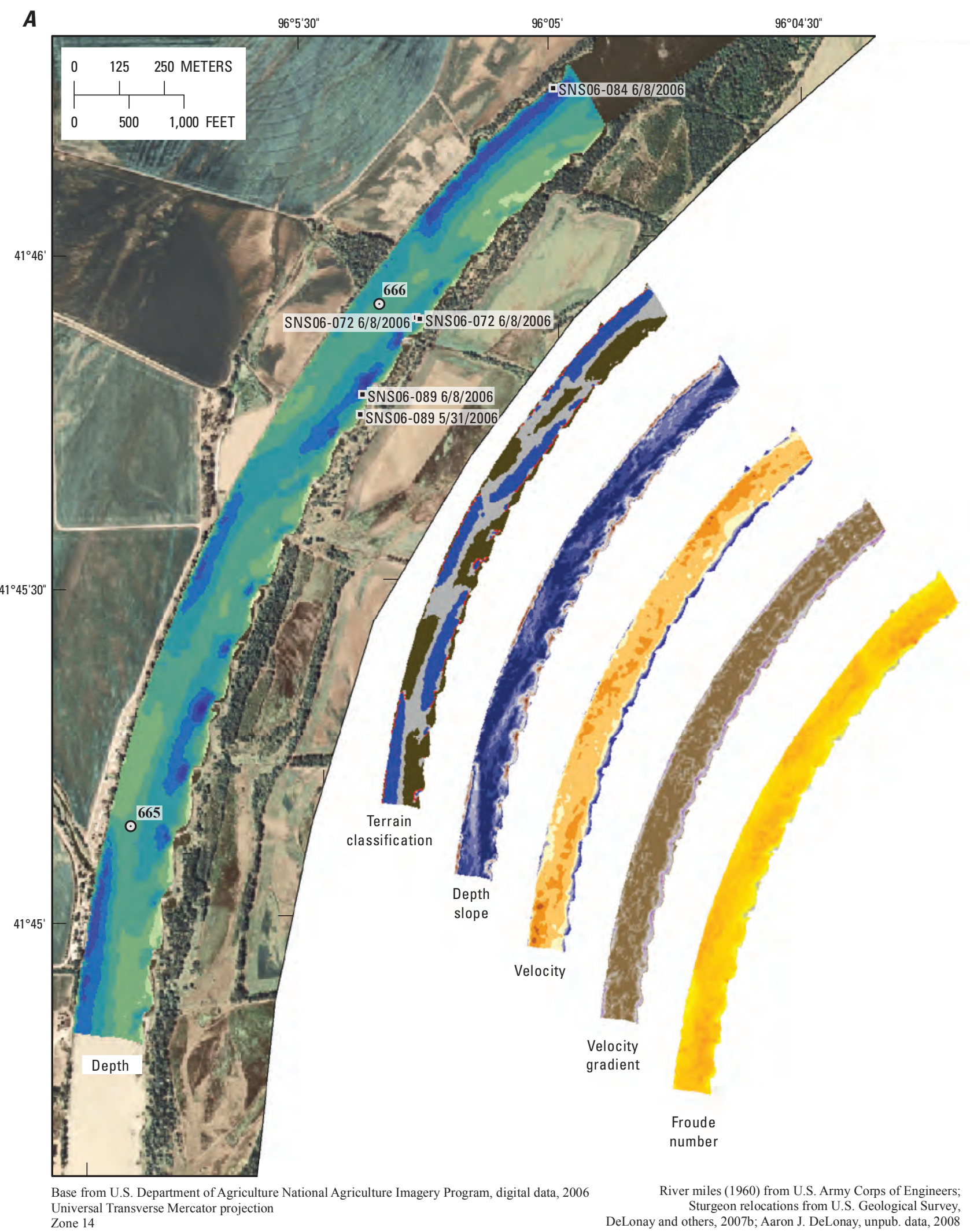

Figure 11. Example reach from the Upstream Channelized section, mapped on June 6, 2006, in the vicinity of river mile 665 . $A$, Maps are shown for each of the continuous variable and the terrain classification. $B$, Scatter plots illustrate relations among the continuous variables. 


\section{EXPLANATION}

Depth, in meters Terrain classification

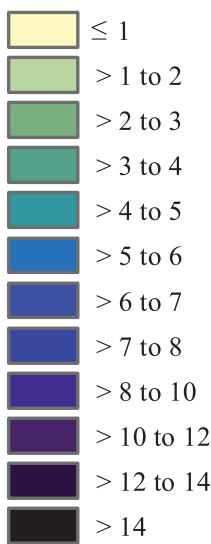

\section{SNS07-141 5/22/2007}

- Sturgeon relocationLabel shows identification code of tagged sturgeon $\odot^{514}$ River-mile markerNumber is distance upstream from the junction with the Mississippi River, in miles

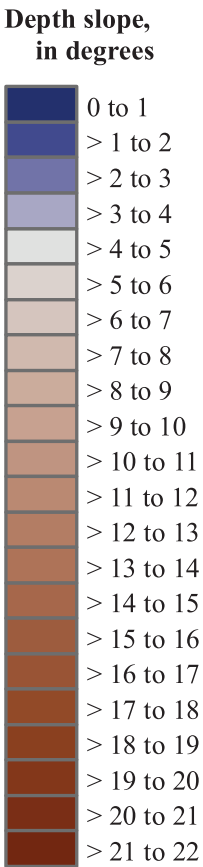
Depth-averaged velocity,
in meters per second

Froude number
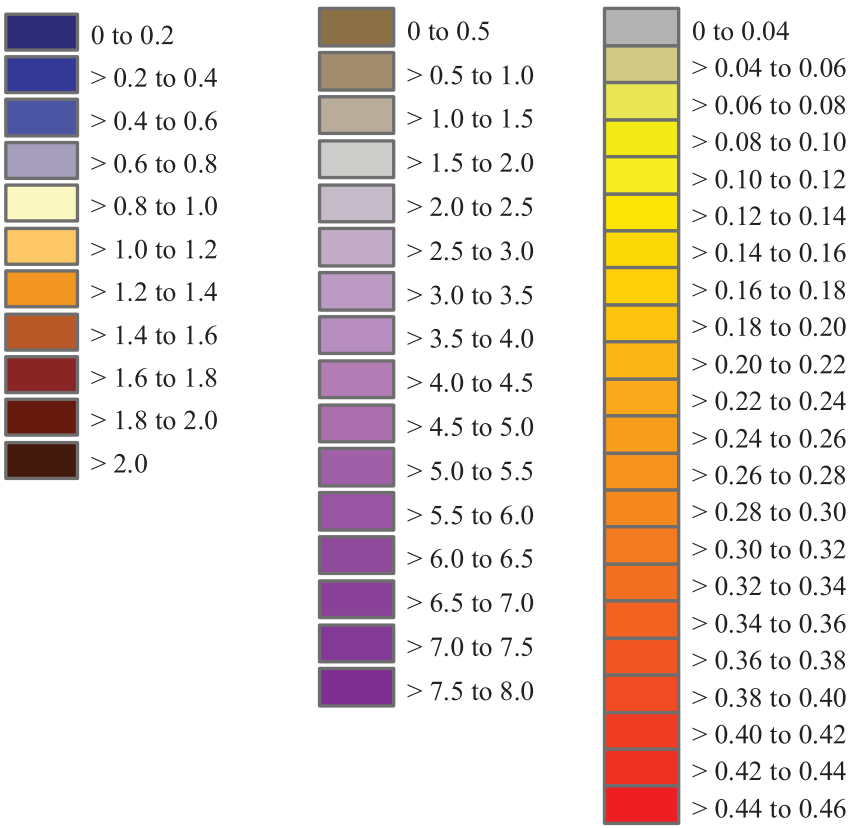

VELOCITY, IN METERS PER SECOND IN PERCENT PER METER

FROUDE NUMBER

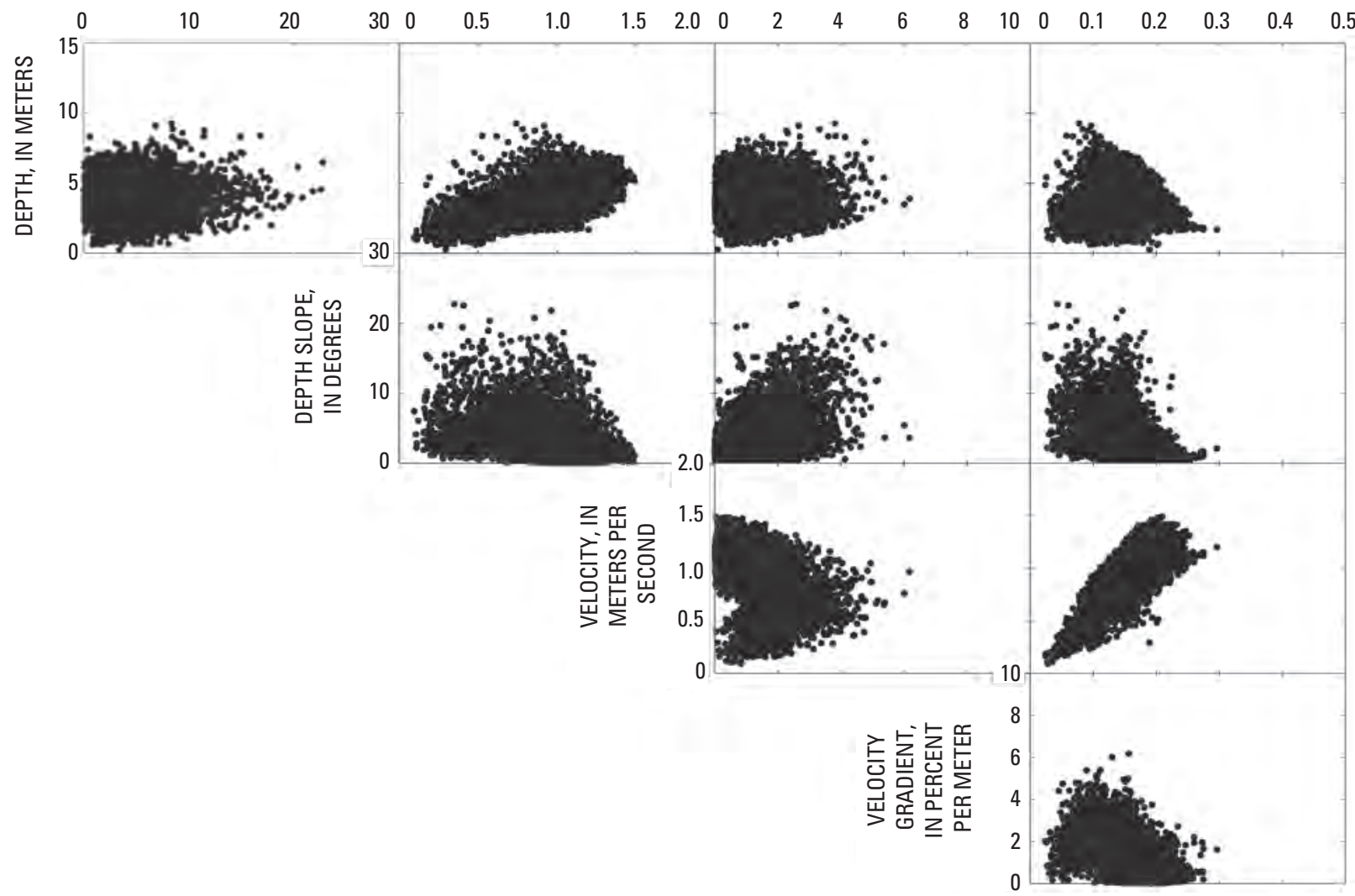

Figure 11. Example reach from the Upstream Channelized section, mapped on June 6, 2006, in the vicinity of river mile 665 . $A$, Maps are shown for each of the continuous variable and the terrain classification. $B$, Scatter plots illustrate relations among the continuous variables.-Continued 


\section{$\boldsymbol{A}$}

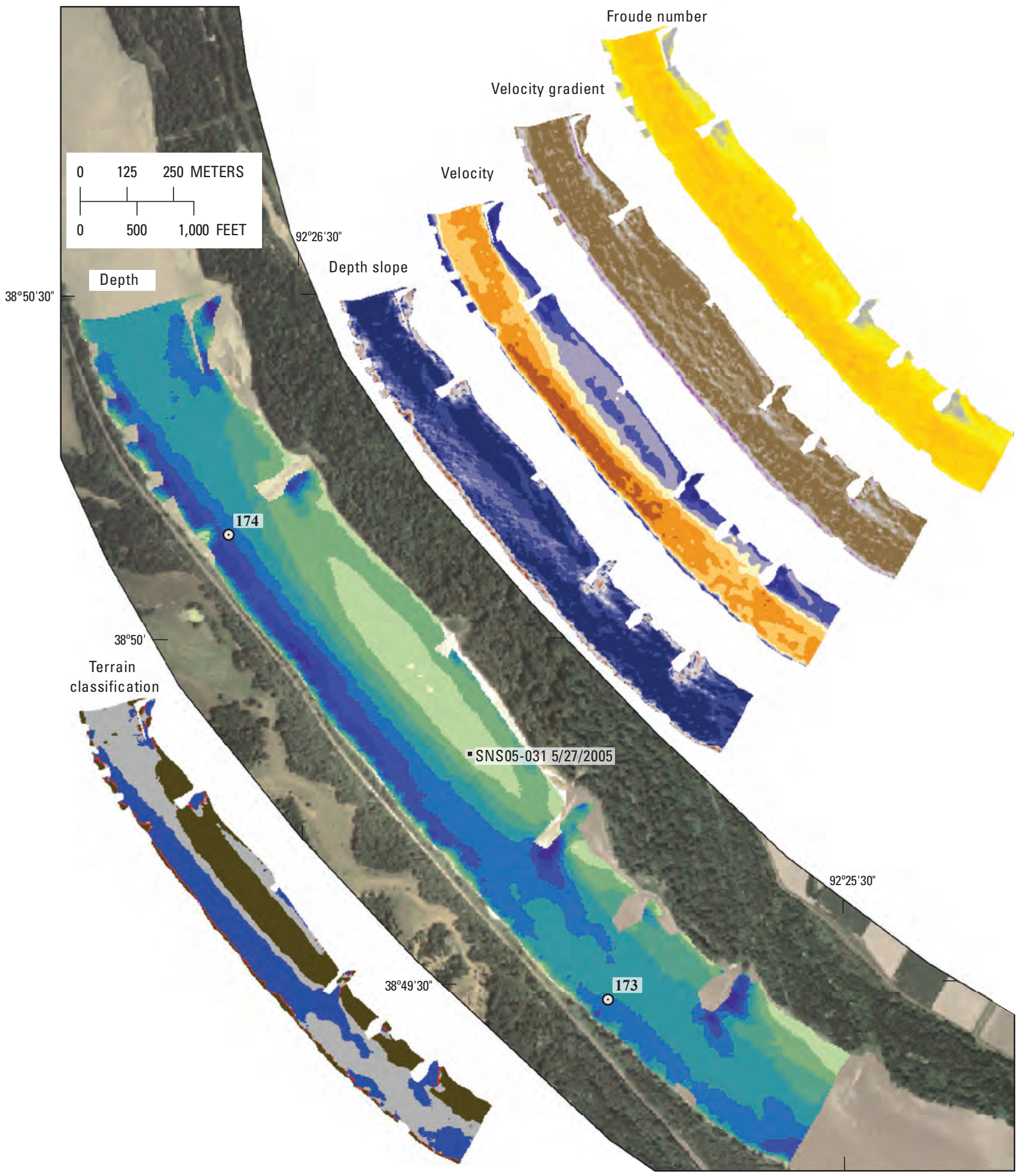

Base from U.S. Department of Agriculture National Agriculture Imagery Program, digital data, 2006 Universal Transverse Mercator projection

River miles (1960) from U.S. Army Corps of Engineers; Sturgeon relocations from U.S. Geological Survey, Zone 15

DeLonay and others, 2007b; Aaron J. DeLonay, unpub. data, 2008

Figure 12. Example reach from the Downstream Channelized section, mapped on June 1, 2005, in the vicinity of river mile 173. $A$, Maps are shown for each of the continuous variable and the terrain classification. $B$, Scatter plots illustrate relations among the continuous variables. 
EXPLANATION

Depth, in meters Terrain classification

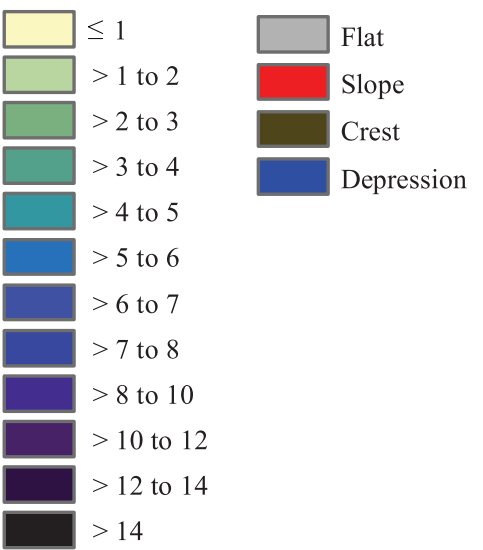

\section{SNS07-141 5/22/2007}

- Sturgeon relocationLabel shows identification code of tagged sturgeon $0^{514}$ and the relocation date
Depth slope, in degrees

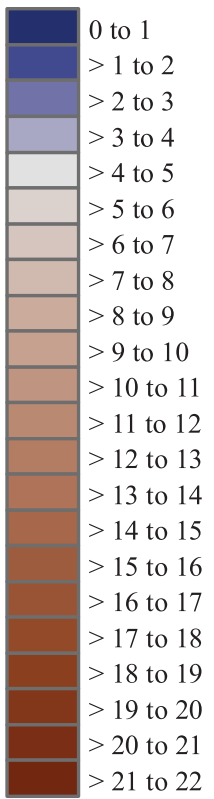

Depth-averaged velocity, Velocity gradient, in meters per second

in percent per meter
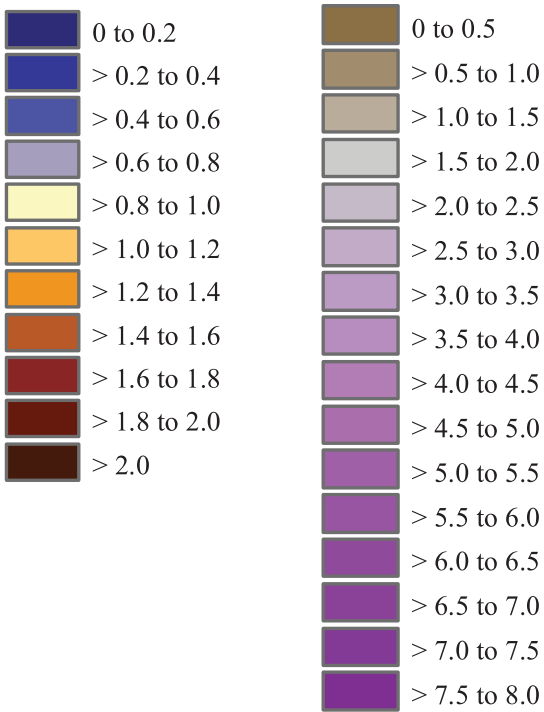

Number is distance upstream from the junction with the Mississippi River, in miles

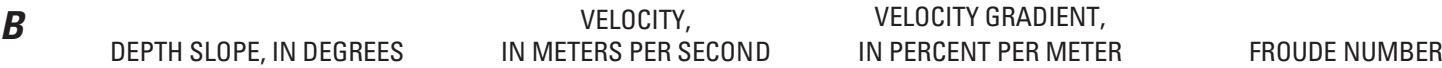

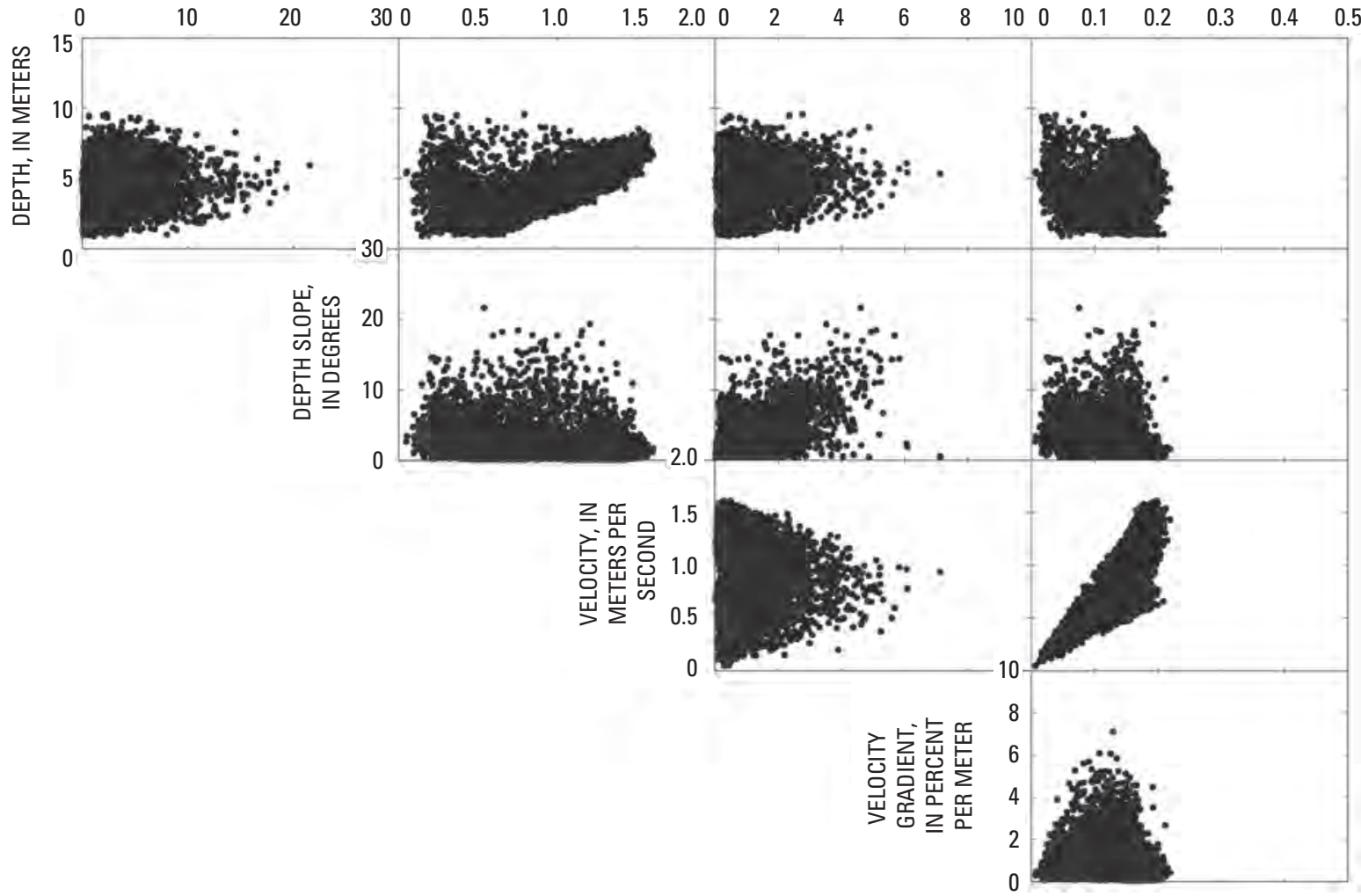

Figure 12. Example reach from the Downstream Channelized section, mapped on June 1, 2005, in the vicinity of river mile 173. $A$, Maps are shown for each of the continuous variable and the terrain classification. $B$, Scatter plots illustrate relations among the continuous variables.-Continued 
Table 2. Bivariate relations among continuous variables for map data.

[For each mapped reach, linear correlation coefficients were computed for each pair of variables. Distributions of these correlation coefficients are presented here for each river section]

\begin{tabular}{|c|c|c|c|c|c|c|c|}
\hline \multirow{2}{*}{ River section } & \multirow{2}{*}{ Variable 1} & \multirow{2}{*}{ Variable 2} & \multicolumn{5}{|c|}{ Linear correlation coefficients ( $r$ ) } \\
\hline & & & Minimum & First quartile & Median & Third quartile & Maximum \\
\hline Minimally Engineered & Depth & Depth slope & 0.07 & 0.30 & 0.38 & 0.45 & 0.56 \\
\hline Upstream Channelized & Depth & Depth slope & -0.29 & -0.05 & 0.03 & 0.11 & 0.31 \\
\hline Downstream Channelized & Depth & Depth slope & -0.24 & 0.11 & 0.16 & 0.22 & 0.39 \\
\hline Minimally Engineered & Depth & Velocity & -0.00 & 0.35 & 0.44 & 0.53 & 0.76 \\
\hline Upstream Channelized & Depth & Velocity & 0.39 & 0.50 & 0.56 & 0.62 & 0.77 \\
\hline Downstream Channelized & Depth & Velocity & 0.14 & 0.50 & 0.62 & 0.69 & 0.86 \\
\hline Minimally Engineered & Depth & Velocity gradient & -0.12 & 0.08 & 0.12 & 0.19 & 0.28 \\
\hline Upstream Channelized & Depth & Velocity gradient & -0.31 & -0.18 & -0.10 & -0.05 & 0.09 \\
\hline Downstream Channelized & Depth & Velocity gradient & -0.20 & -0.02 & 0.07 & 0.12 & 0.27 \\
\hline Minimally Engineered & Depth & Froude number & -0.51 & -0.40 & -0.32 & -0.25 & 0.05 \\
\hline Upstream Channelized & Depth & Froude number & -0.51 & -0.22 & -0.10 & 0.04 & 0.33 \\
\hline Downstream Channelized & Depth & Froude number & -0.12 & 0.06 & 0.16 & 0.29 & 0.55 \\
\hline Minimally Engineered & Depth slope & Velocity & -0.31 & -0.23 & -0.13 & -0.01 & 0.17 \\
\hline Upstream Channelized & Depth slope & Velocity & -0.61 & -0.47 & -0.41 & -0.30 & -0.18 \\
\hline Downstream Channelized & Depth slope & Velocity & -0.59 & -0.38 & -0.31 & -0.21 & 0.04 \\
\hline Minimally Engineered & Depth slope & Velocity gradient & 0.13 & 0.39 & 0.45 & 0.53 & 0.61 \\
\hline Upstream Channelized & Depth slope & Velocity gradient & 0.41 & 0.58 & 0.62 & 0.65 & 0.77 \\
\hline Downstream Channelized & Depth slope & Velocity gradient & 0.14 & 0.37 & 0.43 & 0.54 & 0.71 \\
\hline Minimally Engineered & Depth slope & Froude number & -0.58 & -0.50 & -0.42 & -0.25 & -0.11 \\
\hline Upstream Channelized & Depth slope & Froude number & -0.65 & -0.56 & -0.48 & -0.41 & -0.24 \\
\hline Downstream Channelized & Depth slope & Froude number & -0.65 & -0.48 & -0.41 & -0.35 & -0.19 \\
\hline Minimally Engineered & Velocity & Velocity gradient & -0.38 & -0.22 & -0.14 & -0.06 & 0.08 \\
\hline Upstream Channelized & Velocity & Velocity gradient & -0.64 & -0.56 & -0.50 & -0.42 & -0.27 \\
\hline Downstream Channelized & Velocity & Velocity gradient & -0.36 & -0.17 & -0.13 & -0.08 & 0.13 \\
\hline Minimally Engineered & Velocity & Froude number & 0.51 & 0.63 & 0.67 & 0.74 & 0.88 \\
\hline Upstream Channelized & Velocity & Froude number & 0.50 & 0.69 & 0.75 & 0.82 & 0.92 \\
\hline Downstream Channelized & Velocity & Froude number & 0.59 & 0.84 & 0.89 & 0.91 & 0.98 \\
\hline Minimally Engineered & Velocity gradient & Froude number & -0.45 & -0.35 & -0.27 & -0.10 & 0.05 \\
\hline Upstream Channelized & Velocity gradient & Froude number & -0.62 & -0.52 & -0.46 & -0.41 & -0.23 \\
\hline Downstream Channelized & Velocity gradient & Froude number & -0.37 & -0.23 & -0.16 & -0.13 & 0.12 \\
\hline
\end{tabular}



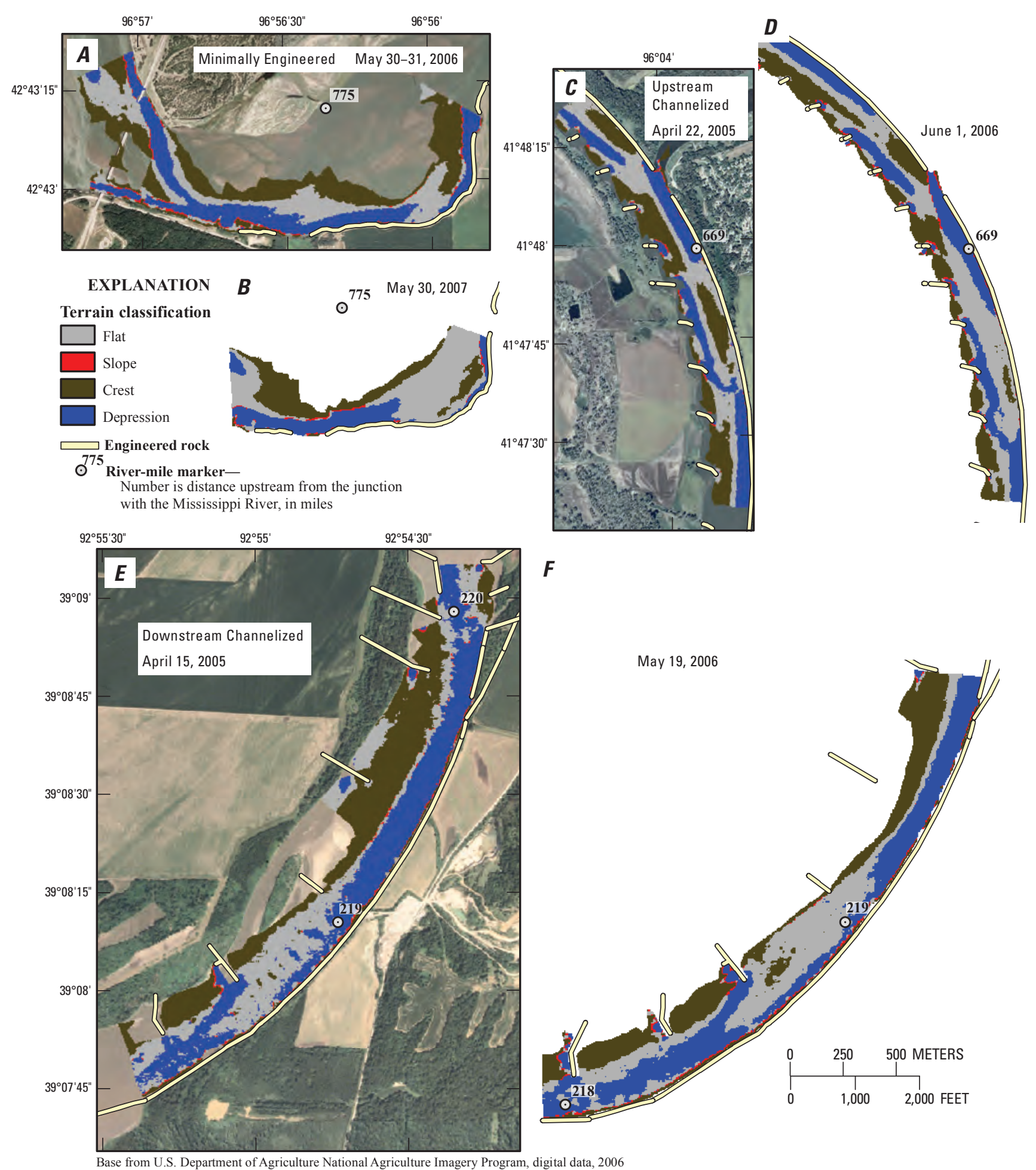

$\boldsymbol{F}$
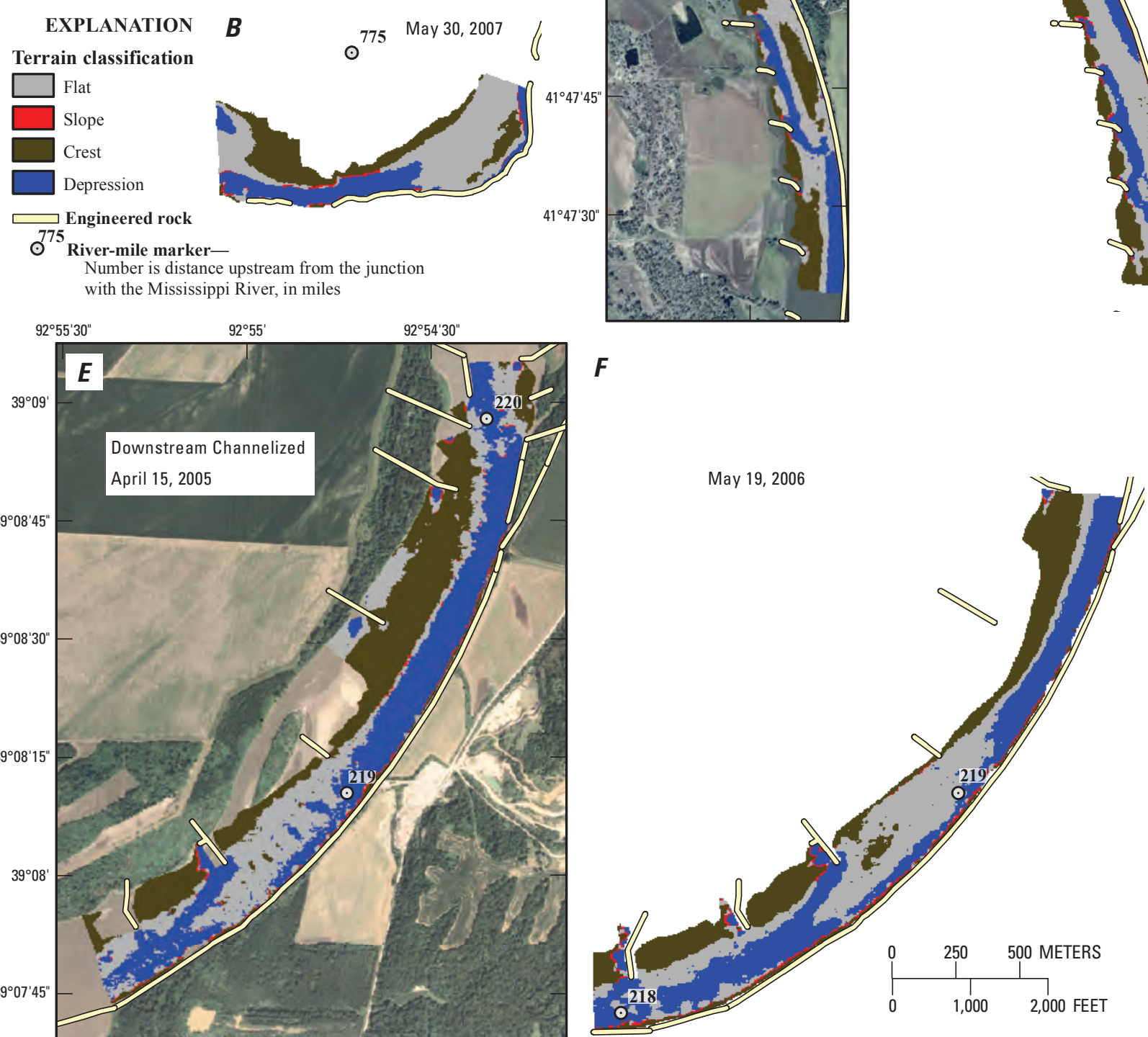

Base from U.S. Department of Agriculture National Agriculture Imagery Program, digital data, 2006 Universal Transverse Mercator projection

Zone 14 (river mile 775 and 669) and 15 (river mile 219)

River miles (1960) from U.S. Army Corps of Engineers

Figure 13. Examples of repeat mapping from each river section, $A, B$, Minimally Engineered, $C, D$, Upstream Channelized, and $E$, F, Downstream Channelized. Maps show the terrain classification representation of each reach because it highlights major channel features and is relatively insensitive to discharge. 
and Jacobson, 2006). Downstream from Ponca State Park, revetment and wing dikes stabilize and constrict the channel. However, morphologic characteristics of the Ponca segment show similarities with the Gavins Point segment (fig. 9). For example, at moderate to low flow, emergent sand bars are common in the Ponca segment. Therefore, we combined the Gavins Point and Ponca segments for analysis and call them the Minimally Engineered section of the Lower Missouri River.

The Minimally Engineered section of river is characterized by a single- or multithread channel with variable - but typically relatively large-widths. The depth histograms tend to be skewed right (fig. 9), meaning that shallow depths are common. As discharge decreases or increases, bar area can readily become emergent or submergent. Mean velocities are relatively low, and velocity histograms tend to be relatively symmetrical (fig. 9); low- and high-velocity habitats are available in similar quantities.

Although the Minimally Engineered section has relatively natural morphologic characteristics, its location just downstream from Gavins Point Dam results in two related effects: (1) this river section has a highly altered flow regime (Galat and Lipkin, 2000; Pegg and others, 2003), and (2) the section is sediment starved and the channel is incising as demonstrated by declining water-surface elevations for the same discharge over time (U.S. Army Corps of Engineers, 2007; Jacobson and others, 2009a). These factors combine to limit the likelihood for connectivity with the historic flood plain in this section of river.

Geomorphic dynamism varies within the section. Results from monitoring by Elliott and others (2009) in 2006 and 2007 showed relatively low magnitude channel change at Yankton, South Dakota (river mile 805), between Gavins Point Dam and the first major tributary. At the Yankton reach, much of the channel is armored with gravel. In contrast, change at Kenslers Bend (river mile 746, in the Ponca segment) was high when scaled to channel size (Elliott and others, 2009). Qualitative observations from repeat mapping at Mulberry Bend (river mile 775, fig. 13) also show notable change in morphology. In addition, bank changes quantified from air photos (Elliott and Jacobson, 2006) attest to the dynamic nature of parts of the Minimally Engineered section of river.

\section{Upstream Channelized Section (Big Sioux and Platte Segments)}

The Big Sioux and Platte segments are managed by the U.S. Army Corps of Engineers for commercial navigation. These segments have been stabilized with revetment and spur dikes and are not subject to planform geomorphic changes except where reconfigured in restoration projects. The engineered structures constrain the channel width to be the narrowest and most uniform of the Lower Missouri River (fig. 7).

The depth histograms in the Upstream Channelized section show a relatively symmetrical shape, in contrast to the skewed nature of the histograms for the Minimally Engineered section (fig. 9). Not much of the channel area is represented by shallow depths. The mean depth based on the mapped reaches is 4 meters, similar to the measured mean depth throughout the length of the river maintained for commercial navigation. The consistency of the widths from the surveyed reaches within the Upstream Channelized section is notable, given that maps were made at a range of discharges (figs. 4, 7). We attribute the consistency in width across discharge to the steepness of the banks in this river section. As discharge increases, the river is constrained by the banks from spreading laterally and there is little opportunity for shallow water. In the Upstream Channelized section, emergent bars are very limited at the typical navigation-season discharges that we observed while mapping. In addition to being deep and narrow, the Upstream Channelized section has the highest mean velocity values based on the reaches we mapped. Relative to those of the other river sections, the composite velocity histograms (fig. 9) are skewed such that low velocity values are more sparsely represented.

In the Upstream Channelized section, the location of thalweg is often inconsistent with the engineered planform of river and often meanders from bank to bank within the planform bends (fig. 11). Furthermore, the position of the thalweg tends to be unstable over time. We observed this qualitatively with repeat mapping of reach maps (fig. 13), and Elliot and others (2009) documented the unstable position of the thalweg quantitatively through cross-section surveys. Those surveys showed that the thalweg moved back and forth between opposite banks of the river within the course of a year. Thus, within the stable planform bends, morphologic change is substantial (Elliott and others, 2009). The spatial arrangement of habitat may change; however, 2-dimensional hydrodynamic modeling work suggests a degree of equilibrium in that proportions of habitat within a reach tend to remain relatively stable over time (Jacobson and others, 2009b).

The flow regime of the Upstream Channelized section also is substantially affected by Gavins Point Dam operations. The regulated flow regime reduces spring and early summer flow pulses relative to the natural background and increases late summer and fall flows to support navigation (fig. 2). The flow regime recovers some variability downstream from the Platte River.

\section{Downstream Channelized Section (Kansas, Grand, and Osage Segments)}

The Kansas, Grand, and Osage segments are managed for commercial navigation and have been engineered with a combination of revetment, spur dikes, and L-head dikes. Similar to the Upstream Channelized section, the planform is stable, with the exception of habitat mitigation projects. The river is dominantly a single thread, but some side-channel chutes exist as a result of a combination of natural processes and engineering for habitat (Jacobson and others, 2001, 2004). Side-channel chutes were excluded from the scope of this project. 
In the Downstream Channelized section, the Missouri River becomes progressively wider in a downstream direction, although mean depths are similar to the Upstream Channelized section (fig. 8). The histograms of depth and velocity for individual reaches tend to be bimodal, and the composite histograms exhibit a more complex, nearly bimodal form relative to the simple unimodal histograms characteristic of the upper segments. The lower peak of the depth and velocity histograms generally represents values along the channel margins in areas behind wing dikes, and the higher peaks generally represent values in the navigation channel. Some of the high depth values are associated with deep scour holes, which are commonly located at the tips of dikes. Bars that are emergent at low flow and submerged at high flow are relatively common.

The location of the thalweg tends to be consistent with the engineered channel planform; that is, in a macroscale outer bend, the thalweg tends to hug the outer bend of the river. Furthermore, the location of the thalweg tends to be persistent, based on qualitative observations from repeat mapping (fig. 13) and from quantitative cross-section surveys in 2006 and 2007 (Elliott and others, 2009).

The flow regime of the Downstream Channelized section has characteristics of the natural flow regime, because tributary inflows lessen the effects of the Missouri River reservoir system (fig. 2). Spring flow pulses are relatively common, as exemplified by the spring 2007 peak flow of over 300,000 cubic feet per second at Boonville, Missouri (fig. 2). Such high flows provide opportunities for the river to connect to its flood plain, especially where levees have been removed.

\section{Habitat Characteristics at Sturgeon Relocations}

In this section, we consider the sturgeon relocations in the context of the reaches where they were relocated. A total of 378 sturgeon relocations fell on 112 maps within 7 days and 10 percent discharge of the map date. These relocations represent 166 individual sturgeon, of which 151 were shovelnose sturgeon and 15 were pallid sturgeon. Of these individuals, the group with the most representatives sharing the same species, sex, and reproductive characteristics were the reproductive female shovelnose sturgeon; 269 of the 378 relocations document positions of reproductive female shovelnose sturgeon. Table 3 documents the species, sex, and reproductive condition of each mapped, relocated sturgeon. Table 4 (at the back of this report) documents the values obtained from the reach maps at each sturgeon relocation point.

Figures 14-18 present histograms of the continuous variables (depth, depth slope, velocity, velocity gradient, and Froude number) for each reach along with the values at each qualifying sturgeon relocation. These figures show: (1) The distribution of relocations among the maps is non-uniform. Most maps have just one or two relocations, though there are exceptions. In particular, the map labeled "070503 f" contained a disproportionate number of relocations; this map was at the mouth of the Big Sioux River. (2) The distribution of mapping effort was non-uniform among the segments. The Big Sioux segment has the most maps. The Platte segment is the least thoroughly documented. (3) Histogram shape varies from reach to reach, but broad similarities are apparent within segments; compare with the composite histograms in figure 9. (4) The values at sturgeon relocations show broad variability in the context of the available habitat.

We are also interested in the question of whether sturgeon select specific habitats, or if instead they use habitat in the proportions in which it is available in a reach. This question can be addressed in a rudimentary but intuitive way by considering the distribution of map variables in comparison to the distribution of values at sturgeon relocations (fig. 19). This figure represents composite data from all of the maps and all of the sturgeon relocations, regardless of map location or sturgeon species. Because these histograms represent composite data from all sections of river and all sturgeon categories, they should be interpreted with caution and the understanding that they represent non-uniformly distributed maps and relocations. These histograms do show that the range of values collectively used by sturgeon is nearly as large as the range of values available to sturgeon. Because the histograms are normalized, the frequency of the sturgeon data relative to the map data is indicative of the relative use of that range of values based on the available dataset. For example, the velocity histograms indicate that sturgeon are underutilizing high velocities relative to their availability. The figure 19 histograms suggest several trends that are supported by more robust data analysis.

Figure 20 presents histogram data similar to figure 19, but results in this figure are separated by river section. In addition, Ivlev's selectivity coefficients are shown for all mapped sections by habitat value (fig. 20). Some coefficients may be misleading because of the way data fell into the arbitrary bin intervals, especially for bins that have a small percentage of available habitat. To minimize this issue, coefficients are shown only for bins with at least one sturgeon relocation. Sturgeon selection for depth varies by river section. In the Minimally Engineered section, sturgeon disproportionately use depths at the deep end of the available range. In contrast, sturgeon in the Upstream and Downstream Engineered sections tend to use both deep and shallow depths in greater proportions than available, while underutilizing the moderate depths that have the greatest availability (in the 4 to 6 meter range). For velocity, the relocation histograms peak at values that are similar for each river section, approximately 0.7 to 0.8 meters per second, though the availability differs considerably among river sections. Selection patterns for depth slope and velocity gradient are similar among river sections, with data indicating disproportionate use of high slope and high velocity gradient areas.

More robust analysis of sturgeon habitat selection is based on the comparison of each sturgeon relocation to the range of values available in the local reach. As described in 
Table 3. Data for sturgeon individuals that were relocated within 7 days and 10 percent discharge of a reach map.

[Sturgeon data from Aaron J. DeLonay and Diana M. Papoulias, unpub. data, 2008. PLS, pallid sturgeon; --, no data; SNS, shovelnose sturgeon;

*, inferred nonreproductive based on reproductive condition of previous year]

\begin{tabular}{|c|c|c|c|c|c|c|}
\hline \multirow{2}{*}{$\begin{array}{c}\text { Sturgeon } \\
\text { identification } \\
\text { code }\end{array}$} & \multirow[b]{2}{*}{ Species } & \multirow[b]{2}{*}{ Sex } & \multirow{2}{*}{$\begin{array}{l}\text { Reproductive } \\
\text { condition } \\
\text { (year) }\end{array}$} & \multicolumn{3}{|c|}{ Relocations on habitat maps within 7 days and 10 percent discharge } \\
\hline & & & & 2005 & 2006 & 2007 \\
\hline PLS04-001 & PLS & Male & -- & 2 & -- & -- \\
\hline PLS04-002 & PLS & Male & -- & 2 & -- & -- \\
\hline PLS04-003 & PLS & Male & -- & 2 & -- & -- \\
\hline PLS05-001 & PLS & Female & -- & 1 & -- & -- \\
\hline PLS05-002 & PLS & Female & -- & 1 & -- & -- \\
\hline PLS05-003 & PLS & Female & -- & 1 & -- & -- \\
\hline PLS05-004 & PLS & Female & -- & 1 & -- & -- \\
\hline PLS05-006 & PLS & Female & -- & -- & 2 & -- \\
\hline PLS06-001 & PLS & Male & Reproductive (2006) & -- & 3 & -- \\
\hline PLS06-003 & PLS & Female & Nonreproductive (2006) & -- & 1 & -- \\
\hline PLS06-004 & PLS & Male & Nonreproductive (2006) & -- & 4 & -- \\
\hline PLS06-006 & PLS & Male & Nonreproductive (2006) & -- & 3 & -- \\
\hline PLS07-003 & PLS & Male & Nonreproductive (2007) & -- & -- & 1 \\
\hline PLS07-004 & PLS & Female & Reproductive (2007) & -- & -- & 4 \\
\hline PLS07-008 & PLS & Male & Reproductive (2007) & -- & -- & 10 \\
\hline SNS05-003 & SNS & Female & Reproductive (2005) & 1 & -- & -- \\
\hline SNS05-006 & SNS & Female & Reproductive (2005) & 1 & -- & -- \\
\hline SNS05-007 & SNS & Female & Reproductive (2005) & 2 & -- & -- \\
\hline SNS05-015 & SNS & Female & Reproductive (2005) & 1 & -- & -- \\
\hline SNS05-017 & SNS & Female & Reproductive (2005) & 2 & -- & -- \\
\hline SNS05-019 & SNS & Female & Reproductive (2005) & 1 & -- & -- \\
\hline SNS05-021 & SNS & Female & Reproductive (2005) & 1 & -- & -- \\
\hline SNS05-022 & SNS & Female & Reproductive (2005) & 1 & -- & -- \\
\hline SNS05-026 & SNS & Female & Reproductive (2005) & 1 & -- & -- \\
\hline SNS05-027 & SNS & Female & Reproductive (2005) & 1 & -- & -- \\
\hline SNS05-028 & SNS & Female & Reproductive (2005) & 1 & -- & -- \\
\hline SNS05-031 & SNS & Female & Reproductive (2005) & 2 & -- & -- \\
\hline SNS05-034 & SNS & Female & Reproductive (2005) & 1 & -- & -- \\
\hline SNS05-037 & SNS & Female & Reproductive (2005) & 1 & -- & -- \\
\hline SNS05-040 & SNS & Female & Reproductive (2005) & 1 & -- & -- \\
\hline SNS05-041 & SNS & Female & Reproductive (2005) & 1 & -- & -- \\
\hline SNS05-042 & SNS & Female & Reproductive (2005) & 1 & -- & -- \\
\hline SNS05-043 & SNS & Female & Reproductive (2005) & 2 & -- & -- \\
\hline SNS05-052 & SNS & Female & Reproductive (2005) & 2 & -- & -- \\
\hline SNS05-053 & SNS & Female & Reproductive (2005) & 1 & -- & -- \\
\hline SNS05-054 & SNS & Female & Reproductive (2005) & 1 & -- & -- \\
\hline SNS05-056 & SNS & Female & Reproductive (2005) & 1 & -- & -- \\
\hline SNS05-057 & SNS & Female & Reproductive (2005) & 2 & -- & -- \\
\hline SNS05-058 & SNS & Female & Reproductive (2005) & 2 & -- & -- \\
\hline SNS05-060 & SNS & Female & Reproductive (2005) & 1 & -- & -- \\
\hline SNS05-061 & SNS & Female & Reproductive (2005) & 6 & -- & -- \\
\hline SNS05-062 & SNS & Female & Reproductive (2005) & 2 & -- & -- \\
\hline SNS05-063 & SNS & Female & Reproductive (2005) & 2 & -- & -- \\
\hline SNS05-064 & SNS & Female & Reproductive (2005) & 2 & -- & -- \\
\hline SNS05-066 & SNS & Female & Reproductive (2005) & 1 & -- & -- \\
\hline SNS05-068 & SNS & Female & Reproductive (2005) & 3 & -- & -- \\
\hline SNS05-069 & SNS & Female & Reproductive (2005) & 1 & -- & -- \\
\hline SNS05-070 & SNS & Female & Reproductive (2005) & 2 & -- & -- \\
\hline SNS05-071 & SNS & Female & Reproductive (2005) & 4 & -- & -- \\
\hline SNS05-072 & SNS & Female & Reproductive (2005) & 3 & -- & -- \\
\hline SNS05-073 & SNS & Female & Reproductive (2005) & 2 & -- & -- \\
\hline SNS05-074 & SNS & Female & Reproductive (2005) & 3 & -- & -- \\
\hline
\end{tabular}


Table 3. Data for sturgeon individuals that were relocated within 7 days and 10 percent discharge of a reach map.-Continued

[Sturgeon data from Aaron J. DeLonay and Diana M. Papoulias, unpub. data, 2008. PLS, pallid sturgeon; --, no data; SNS, shovelnose sturgeon; *, inferred nonreproductive based on reproductive condition of previous year]

\begin{tabular}{|c|c|c|c|c|c|c|}
\hline \multirow{2}{*}{$\begin{array}{c}\text { Sturgeon } \\
\text { identification } \\
\text { code }\end{array}$} & \multirow{2}{*}{ Species } & \multirow{2}{*}{ Sex } & \multirow{2}{*}{$\begin{array}{c}\text { Reproductive } \\
\text { condition } \\
\text { (year) }\end{array}$} & \multicolumn{3}{|c|}{ Relocations on habitat maps within 7 days and 10 percent discharge } \\
\hline & & & & 2005 & 2006 & 2007 \\
\hline SNS05-075 & SNS & Female & Reproductive (2005) & 2 & -- & -- \\
\hline SNS05-076 & SNS & Female & Reproductive (2005) & 4 & -- & -- \\
\hline SNS05-077 & SNS & Female & Reproductive (2005) & 2 & -- & -- \\
\hline SNS05-082 & SNS & Female & Reproductive (2005) & 3 & -- & -- \\
\hline SNS05-083 & SNS & Female & Reproductive (2005) & 2 & -- & -- \\
\hline SNS05-084 & SNS & Female & Reproductive (2005) & 5 & -- & -- \\
\hline SNS05-085 & SNS & Female & Reproductive (2005) & 1 & -- & -- \\
\hline SNS05-087 & SNS & Female & Reproductive (2005) & 1 & -- & -- \\
\hline SNS05-089 & SNS & Female & Reproductive (2005) & 2 & -- & -- \\
\hline SNS05-094 & SNS & Female & Reproductive (2005) & 2 & -- & -- \\
\hline SNS05-095 & SNS & Female & Reproductive (2005) & 2 & -- & -- \\
\hline SNS05-096 & SNS & Female & Reproductive (2005) & 1 & -- & -- \\
\hline SNS05-097 & SNS & Female & Reproductive (2005) & 2 & -- & -- \\
\hline SNS05-098 & SNS & Female & Reproductive (2005) & 2 & -- & -- \\
\hline SNS05-099 & SNS & Female & Reproductive (2005) & 1 & -- & -- \\
\hline SNS05-100 & SNS & Female & Reproductive (2005) & 1 & -- & -- \\
\hline SNS05-101 & SNS & Female & Reproductive (2005) & 4 & -- & -- \\
\hline SNS06-010 & SNS & Female & Reproductive (2006) & -- & 1 & -- \\
\hline SNS06-011 & SNS & Female & Reproductive (2006) & -- & 2 & -- \\
\hline SNS06-012 & SNS & Female & Reproductive (2006) & -- & 1 & -- \\
\hline SNS06-028 & SNS & Female & Reproductive (2006) & -- & 1 & -- \\
\hline SNS06-034 & SNS & Female & Reproductive (2006) & -- & 1 & -- \\
\hline SNS06-038 & SNS & Female & Reproductive (2006) & -- & 2 & -- \\
\hline SNS06-044 & SNS & Female & Reproductive (2006) & -- & 2 & -- \\
\hline SNS06-047 & SNS & Female & Reproductive (2006) & -- & 3 & -- \\
\hline SNS06-051 & SNS & Female & Reproductive (2006) & -- & 1 & -- \\
\hline SNS06-057 & SNS & Female & Nonreproductive (2007)* & -- & -- & 1 \\
\hline SNS06-058 & SNS & Female & Reproductive (2006) & -- & 2 & -- \\
\hline SNS06-060 & SNS & Female & Reproductive (2006) & -- & 1 & 1 \\
\hline SNS06-060 & SNS & Female & Nonreproductive (2007)* & -- & 1 & 1 \\
\hline SNS06-067 & SNS & Female & Reproductive (2006) & -- & 2 & -- \\
\hline SNS06-072 & SNS & Female & Reproductive (2006) & -- & 3 & -- \\
\hline SNS06-075 & SNS & Female & Nonreproductive (2007)* & -- & -- & 1 \\
\hline SNS06-076 & SNS & Female & Reproductive (2006) & -- & 3 & -- \\
\hline SNS06-077 & SNS & Female & Reproductive (2006) & -- & 1 & -- \\
\hline SNS06-083 & SNS & Female & Reproductive (2006) & -- & 4 & -- \\
\hline SNS06-084 & SNS & Female & Reproductive (2006) & -- & 1 & -- \\
\hline SNS06-085 & SNS & Female & Reproductive (2006) & -- & 6 & -- \\
\hline SNS06-089 & SNS & Female & Reproductive (2006) & -- & 2 & -- \\
\hline SNS06-092 & SNS & Female & Nonreproductive (2007)* & -- & -- & 1 \\
\hline SNS07-009 & SNS & Female & Nonreproductive (2007) & -- & -- & 2 \\
\hline SNS07-010 & SNS & Female & Reproductive (2007) & -- & -- & 3 \\
\hline SNS07-019 & SNS & Female & Reproductive (2007) & -- & -- & 1 \\
\hline SNS07-021 & SNS & Female & Reproductive (2007) & -- & -- & 2 \\
\hline SNS07-025 & SNS & Female & Reproductive (2007) & -- & -- & 3 \\
\hline SNS07-030 & SNS & Female & Reproductive (2007) & -- & -- & 3 \\
\hline SNS07-033 & SNS & Female & Reproductive (2007) & -- & -- & 1 \\
\hline SNS07-034 & SNS & Male & Nonreproductive (2007) & -- & -- & 3 \\
\hline SNS07-035 & SNS & Female & Reproductive (2007) & -- & -- & 3 \\
\hline SNS07-040 & SNS & Female & Reproductive (2007) & -- & -- & 5 \\
\hline SNS07-042 & SNS & Intersex & Intersex (2007) & -- & -- & 1 \\
\hline SNS07-045 & SNS & Female & Reproductive (2007) & -- & -- & 1 \\
\hline
\end{tabular}


Table 3. Data for sturgeon individuals that were relocated within 7 days and 10 percent discharge of a reach map.-Continued

[Sturgeon data from Aaron J. DeLonay and Diana M. Papoulias, unpub. data, 2008. PLS, pallid sturgeon; --, no data; SNS, shovelnose sturgeon;

*, inferred nonreproductive based on reproductive condition of previous year]

\begin{tabular}{|c|c|c|c|c|c|c|}
\hline \multirow{2}{*}{$\begin{array}{c}\text { Sturgeon } \\
\text { identification } \\
\text { code }\end{array}$} & \multirow[b]{2}{*}{ Species } & \multirow[b]{2}{*}{ Sex } & \multirow{2}{*}{$\begin{array}{l}\text { Reproductive } \\
\text { condition } \\
\text { (year) }\end{array}$} & \multicolumn{3}{|c|}{ Relocations on habitat maps within 7 days and 10 percent discharge } \\
\hline & & & & 2005 & 2006 & 2007 \\
\hline SNS07-046 & SNS & Female & Reproductive (2007) & -- & -- & 4 \\
\hline SNS07-055 & SNS & Female & Reproductive (2007) & -- & -- & 3 \\
\hline SNS07-057 & SNS & Female & Reproductive (2007) & -- & -- & 1 \\
\hline SNS07-059 & SNS & Female & Reproductive (2007) & -- & -- & 6 \\
\hline SNS07-066 & SNS & Male & Reproductive (2007) & -- & -- & 1 \\
\hline SNS07-072 & SNS & Female & Reproductive (2007) & -- & -- & 3 \\
\hline SNS07-073 & SNS & Female & Reproductive (2007) & -- & -- & 3 \\
\hline SNS07-075 & SNS & Female & Reproductive (2007) & -- & -- & 3 \\
\hline SNS07-076 & SNS & Female & Reproductive (2007) & -- & -- & 1 \\
\hline SNS07-077 & SNS & Female & Reproductive (2007) & -- & -- & 2 \\
\hline SNS07-079 & SNS & Female & Reproductive (2007) & -- & -- & 6 \\
\hline SNS07-080 & SNS & Male & Reproductive (2007) & -- & -- & 1 \\
\hline SNS07-081 & SNS & Female & Reproductive (2007) & -- & -- & 1 \\
\hline SNS07-084 & SNS & Female & Nonreproductive (2007) & -- & -- & 2 \\
\hline SNS07-085 & SNS & Female & Reproductive (2007) & -- & -- & 1 \\
\hline SNS07-088 & SNS & Female & Reproductive (2007) & -- & -- & 1 \\
\hline SNS07-089 & SNS & Female & Reproductive (2007) & -- & -- & 3 \\
\hline SNS07-092 & SNS & Female & Reproductive (2007) & -- & -- & 2 \\
\hline SNS07-093 & SNS & Female & Reproductive (2007) & -- & -- & 5 \\
\hline SNS07-094 & SNS & Female & Reproductive (2007) & -- & -- & 2 \\
\hline SNS07-098 & SNS & Female & Reproductive (2007) & -- & -- & 3 \\
\hline SNS07-100 & SNS & Female & Nonreproductive (2007) & -- & -- & 4 \\
\hline SNS07-104 & SNS & Female & Reproductive (2007) & -- & -- & 2 \\
\hline SNS07-106 & SNS & Female & Nonreproductive (2007) & -- & -- & 3 \\
\hline SNS07-107 & SNS & Female & Nonreproductive (2007) & -- & -- & 5 \\
\hline SNS07-109 & SNS & Female & Nonreproductive (2007) & -- & -- & 3 \\
\hline SNS07-111 & SNS & Female & Reproductive (2007) & -- & -- & 3 \\
\hline SNS07-115 & SNS & Male & Reproductive (2007) & -- & -- & 1 \\
\hline SNS07-116 & SNS & Female & Reproductive (2007) & -- & -- & 1 \\
\hline SNS07-118 & SNS & Female & Reproductive (2007) & -- & -- & 2 \\
\hline SNS07-122 & SNS & Female & Reproductive (2007) & -- & -- & 1 \\
\hline SNS07-123 & SNS & Intersex & Intersex (2007) & -- & -- & 2 \\
\hline SNS07-124 & SNS & Female & Reproductive (2007) & -- & -- & 4 \\
\hline SNS07-126 & SNS & Female & Reproductive (2007) & -- & -- & 1 \\
\hline SNS07-127 & SNS & Female & Reproductive (2007) & -- & -- & 2 \\
\hline SNS07-129 & SNS & Female & Reproductive (2007) & -- & -- & 2 \\
\hline SNS07-132 & SNS & Female & Nonreproductive (2007) & -- & -- & 3 \\
\hline SNS07-133 & SNS & Female & Reproductive (2007) & -- & -- & 2 \\
\hline SNS07-135 & SNS & Female & Reproductive (2007) & -- & -- & 2 \\
\hline SNS07-137 & SNS & Female & Reproductive (2007) & -- & -- & 1 \\
\hline SNS07-138 & SNS & Female & Reproductive (2007) & -- & -- & 3 \\
\hline SNS07-139 & SNS & Female & Nonreproductive (2007) & -- & -- & 2 \\
\hline SNS07-141 & SNS & Male & Reproductive (2007) & -- & -- & 2 \\
\hline SNS07-143 & SNS & Male & Reproductive (2007) & -- & -- & 2 \\
\hline SNS07-144 & SNS & Male & Reproductive (2007) & -- & -- & 2 \\
\hline SNS07-145 & SNS & Male & Reproductive (2007) & -- & -- & 1 \\
\hline SNS07-147 & SNS & Male & Reproductive (2007) & -- & -- & 2 \\
\hline SNS07-149 & SNS & Female & Nonreproductive (2007) & -- & -- & 2 \\
\hline SNS07-150 & SNS & Male & Reproductive (2007) & -- & -- & 3 \\
\hline SNS07-153 & SNS & Female & Reproductive (2007) & -- & -- & 2 \\
\hline SNS07-154 & SNS & Female & Reproductive (2007) & -- & -- & 4 \\
\hline SNS07-155 & SNS & Female & Reproductive (2007) & -- & -- & 3 \\
\hline
\end{tabular}


Table 3. Data for sturgeon individuals that were relocated within 7 days and 10 percent discharge of a reach map.-Continued

[Sturgeon data from Aaron J. DeLonay and Diana M. Papoulias, unpub. data, 2008. PLS, pallid sturgeon; --, no data; SNS, shovelnose sturgeon;

*, inferred nonreproductive based on reproductive condition of previous year]

\begin{tabular}{|c|c|c|c|c|c|c|}
\hline \multirow{2}{*}{$\begin{array}{c}\text { Sturgeon } \\
\text { identification } \\
\text { code }\end{array}$} & \multirow[b]{2}{*}{ Species } & \multirow[b]{2}{*}{ Sex } & \multirow{2}{*}{$\begin{array}{l}\text { Reproductive } \\
\text { condition } \\
\text { (year) }\end{array}$} & \multicolumn{3}{|c|}{ Relocations on habitat maps within 7 days and 10 percent discharge } \\
\hline & & & & 2005 & 2006 & 2007 \\
\hline SNS07-157 & SNS & Male & Reproductive (2007) & -- & -- & 6 \\
\hline SNS07-159 & SNS & Male & Reproductive (2007) & -- & -- & 1 \\
\hline SNS07-162 & SNS & Female & Reproductive (2007) & -- & -- & 4 \\
\hline SNS07-164 & SNS & Female & Reproductive (2007) & -- & -- & 4 \\
\hline SNS07-165 & SNS & Female & Nonreproductive (2007) & -- & -- & 2 \\
\hline SNS07-166 & SNS & Female & Nonreproductive (2007) & -- & -- & 3 \\
\hline SNS07-169 & SNS & Male & Reproductive (2007) & -- & -- & 3 \\
\hline SNS07-170 & SNS & Female & Reproductive (2007) & -- & -- & 6 \\
\hline SNS07-171 & SNS & Male & Nonreproductive (2007) & -- & -- & 5 \\
\hline SNS07-175 & SNS & Female & Reproductive (2007) & -- & -- & 6 \\
\hline SNS07-176 & SNS & Female & Reproductive (2007) & -- & -- & 3 \\
\hline
\end{tabular}

the "Analysis Approach" section, we determined within which decile range each sturgeon relocation fell. Each decile range represents an equal area on the map, so if sturgeon are distributed randomly with respect to a given variable, then a similar number of relocations should fall within each decile range. Results presented in table 5 have been compiled by river section and sturgeon attributes (species, sex, and reproductive condition). For completeness, this table includes all categories of species, sex, and reproductive condition, even though the number of relocations in many categories is smaller than needed to draw robust conclusions.

For reproductive female shovelnose sturgeon, plots of the percent of relocations in each decile range show several trends that are consistent among all river sections (fig. 21). Reproductive female shovelnose sturgeon frequently were observed in areas of high depth slope, low velocity, high velocity gradient, and/or low Froude number. Relations with depth are somewhat more complex and inconsistent among river sections. In the Downstream Channelized section, sturgeon select the shallowest decile of depths while avoiding this decile in the Minimally Engineered section.

Examined by year in addition to river section (table 6), the results among years are relatively similar (if less definitive, given the smaller numbers of relocations). Patterns of depth slope, velocity gradient, and Froude number are particularly robust and consistent between years and river sections, with typically greater proportions of reproductive female shovelnose sturgeon at high depth slope, high velocity gradient, and/ or low Froude number.

Table 7 documents the proportion of each categorical variable represented in each reach and number of relocations within each categorical value; table 8 contains a summary of the categorical data by river section. Examination of categorical variable summaries (table 8) indicates use of some habitat categories in greater proportion than their availability. In particular, sturgeon seem to select for the engineered structure and bedrock category (12.2 percent of the relocations in 3.4 percent of the area). This category is dominated by engineered structures (wing dikes and revetment). Sturgeon appear to avoid areas of high sediment transport. Given that high sediment transport occurs in areas of high velocity and Froude number, these results show consistency with the results from continuous variable analysis. Results from the terrain classification analysis show selection for sloping terrain units (7.5 percent of relocations in 2.1 percent of area), a result that is consistent with the findings from the analysis of depth slope as a continuous variable. Table 8 contains summary data for shallow-water habitat; however, these results should be interpreted with caution because maps tend to err somewhat on the side of under representing shallow-water habitat as a result of depth limitations on boat navigation. These tentative results suggest little selection or avoidance for shallow-water habitat.

\section{Patterns of Sturgeon Habitat Use Considered in Map Context}

The results from the decile analysis demonstrate a nonrandom distribution of sturgeon in relation to various environmental variables. As a visualization exercise, we explored the spatial distribution of the decile ranges that sturgeon tended to select to address some basic questions: Where do these values occur? How do the different variables interact in a spatial context? How do the patterns differ by river section?

We reclassified cells in the map for each variable such that a " 1 " represented the 2 most selected deciles and a " 0 " represented the remaining deciles. Because relations between habitat use and depth are inconsistent in the existing dataset, we omitted depth from this exploratory model. Furthermore, because velocity and Froude number are highly correlated, and the relations of habitat use appear to be more strongly associated with Froude number than with velocity, we omitted velocity. 

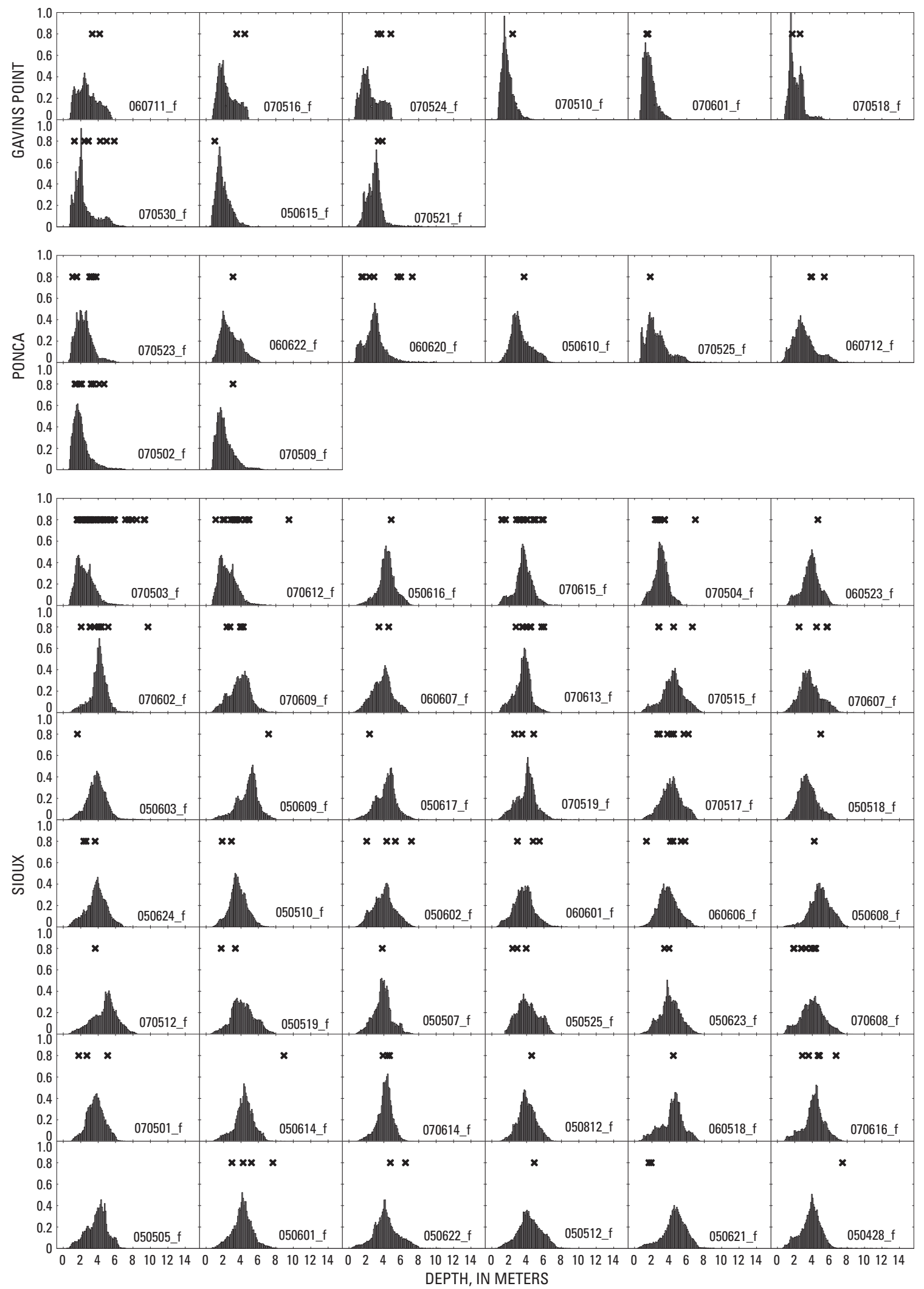

Figure 14. Histograms of depth maps for each reach with points representing sturgeon relocations. Each " $x$ " represents the depth value at a sturgeon relocation with respect to the $x$-axis. Histograms are ordered in descending order by river mile. The identification code includes the last two digits of the year, the two-digit month, and two-digit day of the month, plus a boat identifier ( $b$ or $\mathrm{f}$ ); this information is sufficient to uniquely identify each map and to cross-reference with the tables of Reuter and others (2008). 

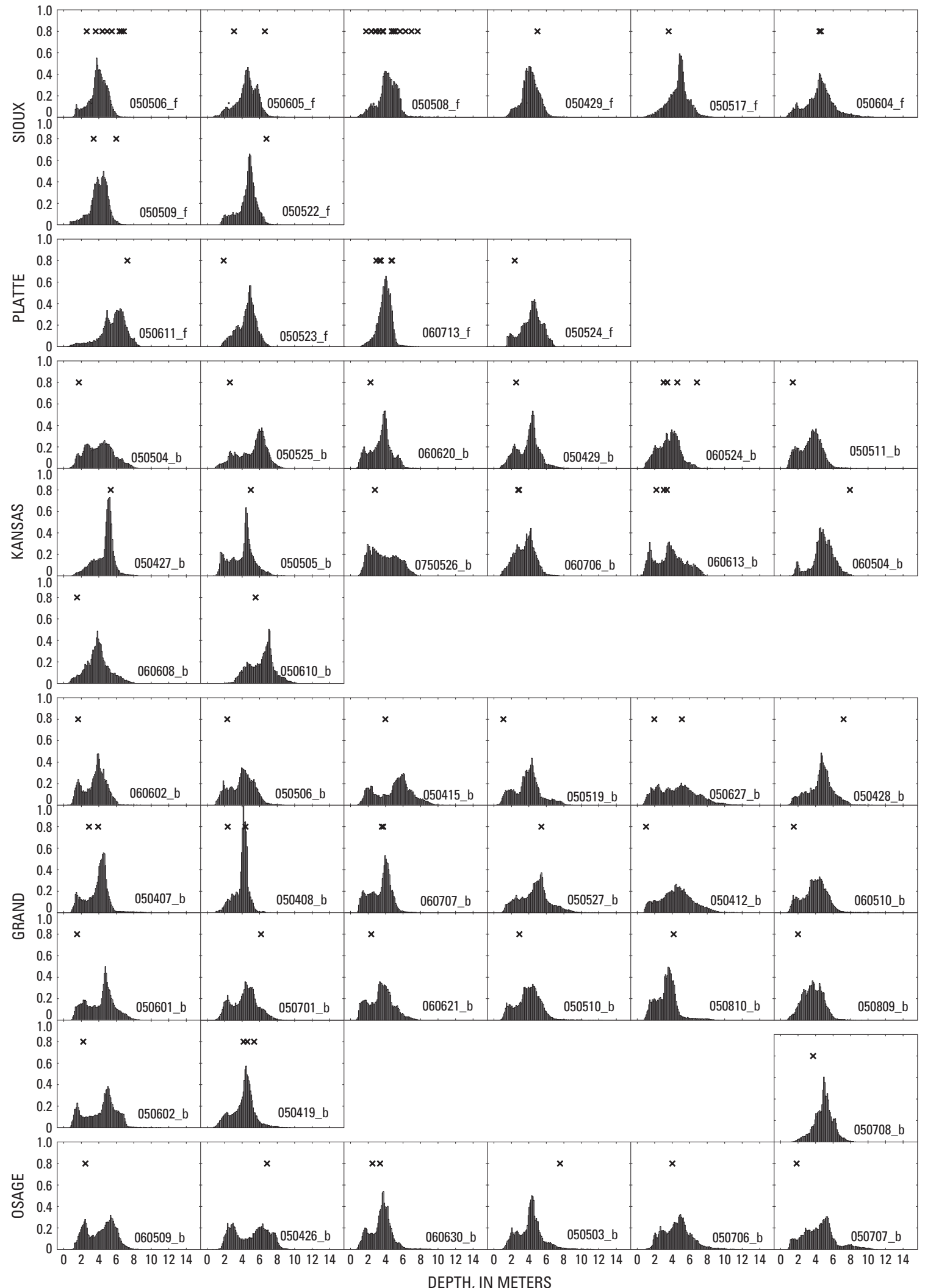

Figure 14. Histograms of depth maps for each reach with points representing sturgeon relocations. Each " $x$ " represents the depth value at a sturgeon relocation with respect to the $x$-axis. Histograms are ordered in descending order by river mile. The identification code includes the last two digits of the year, the two-digit month, and two-digit day of the month, plus a boat identifier ( $b$ or f); this information is sufficient to uniquely identify each map and to cross-reference with the tables of Reuter and others (2008).-Continued 

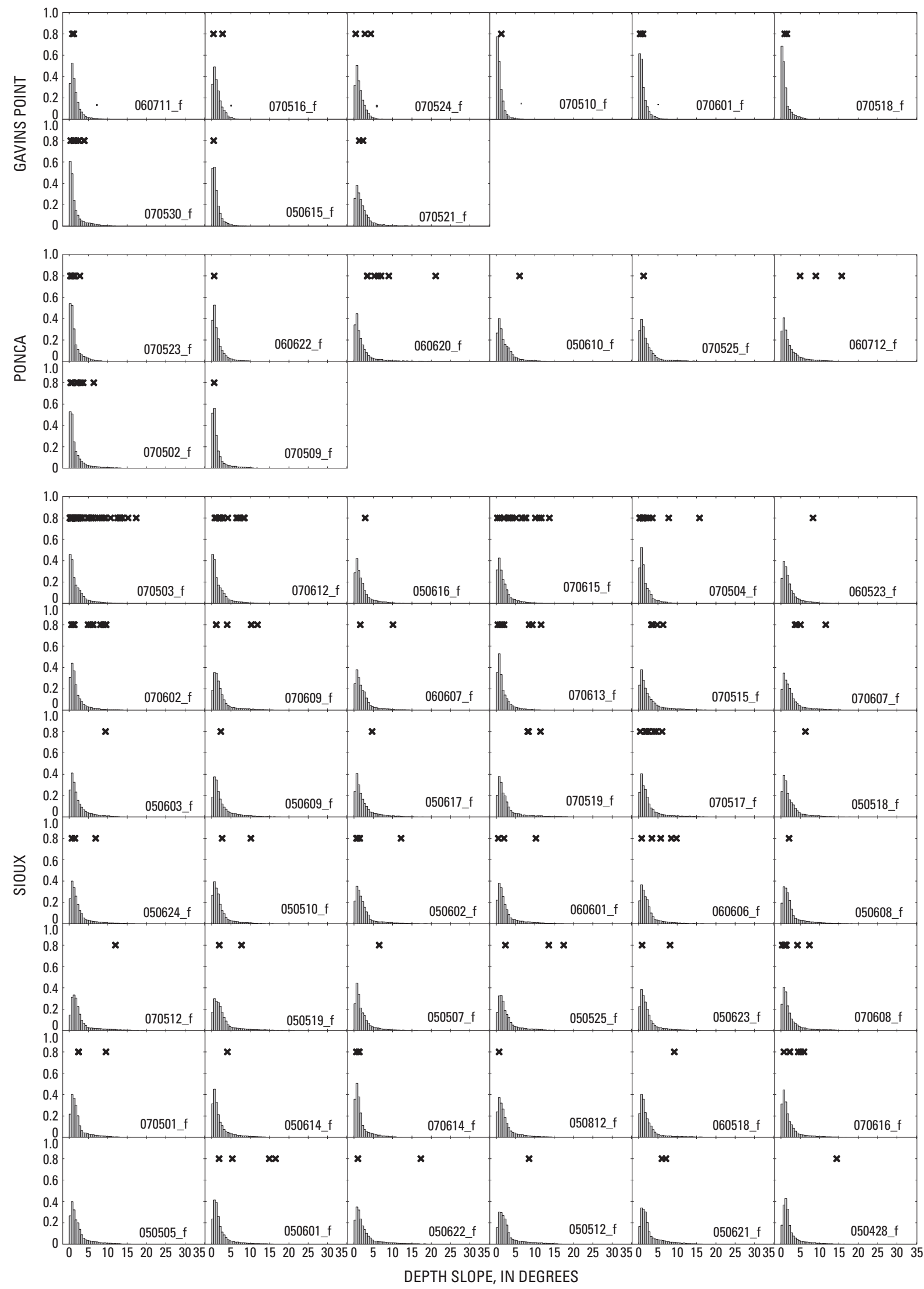

Figure 15. Histograms of depth slope maps for each reach with points representing sturgeon relocations. Histograms are ordered in descending order by river mile. The identification code includes the last two digits of the year, the twodigit month, and two-digit day of the month, plus a boat identifier ( $b$ or f). 

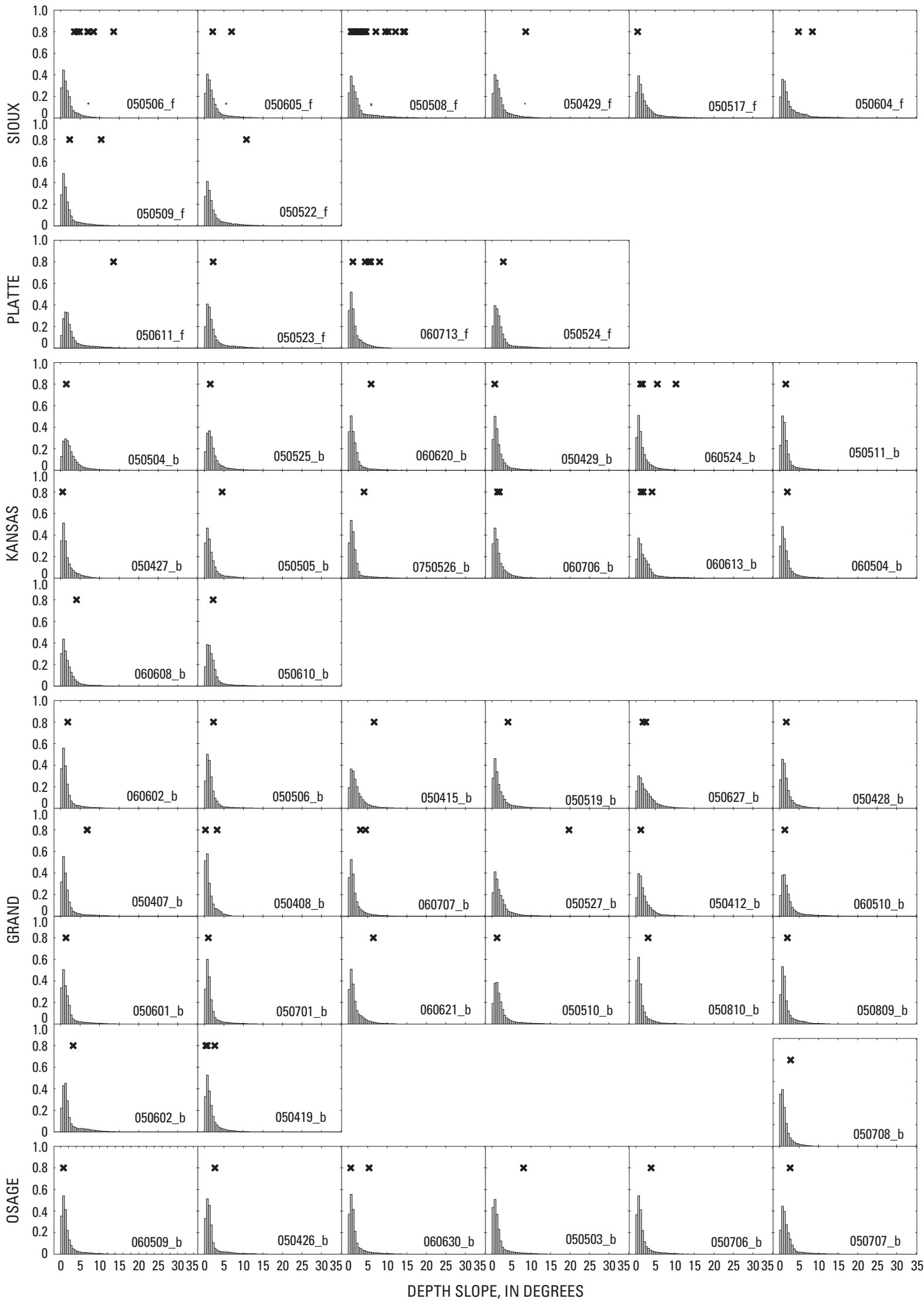

Figure 15. Histograms of depth slope maps for each reach with points representing sturgeon relocations. Histograms are ordered in descending order by river mile. The identification code includes the last two digits of the year, the twodigit month, and two-digit day of the month, plus a boat identifier ( $b$ or $\mathrm{f}$ ).-Continued 

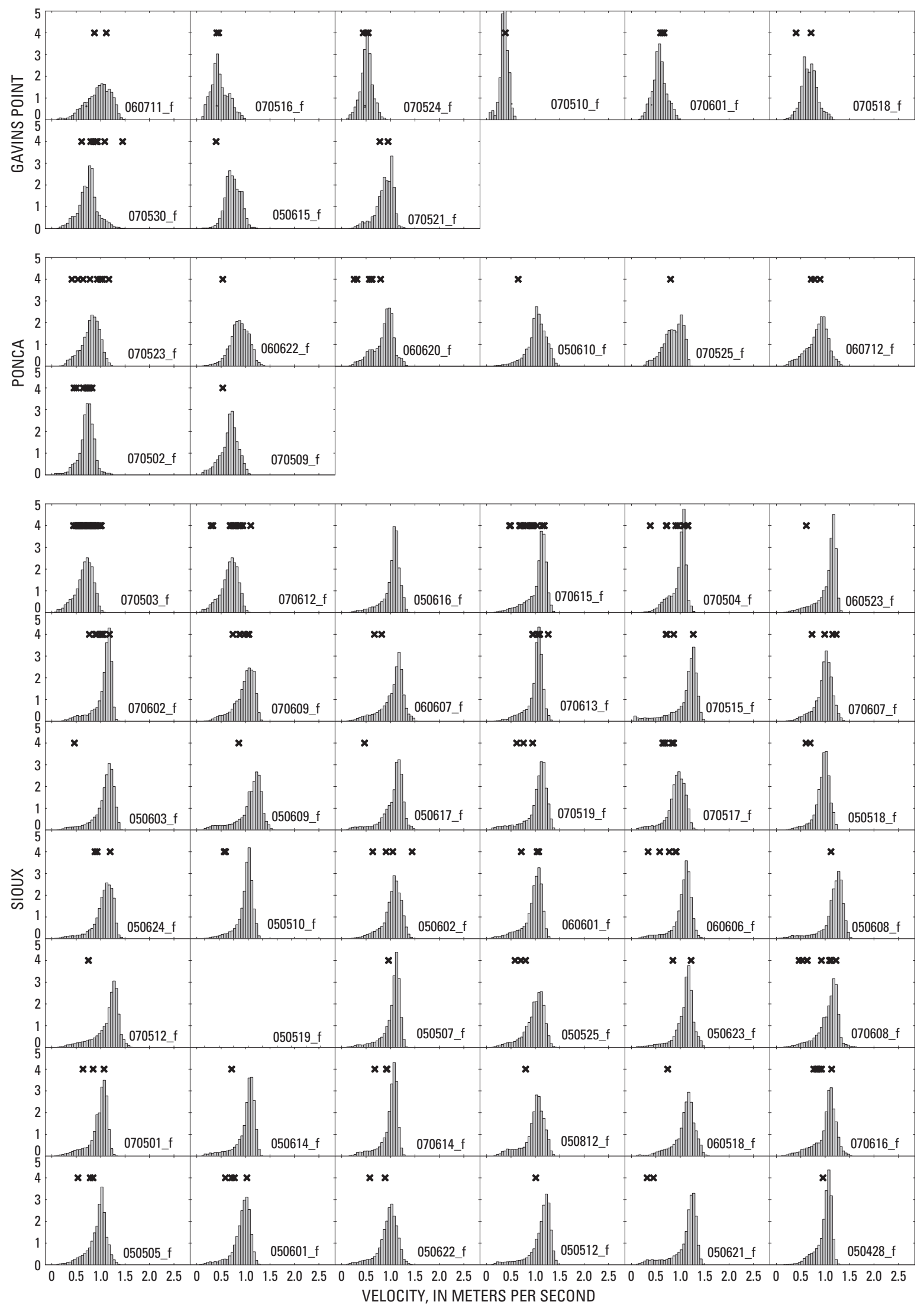

Figure 16. Histograms of velocity maps for each reach with points representing sturgeon relocations. Histograms are ordered in descending order by river mile. The identification code includes the last two digits of the year, the two-digit month, and two-digit day of the month, plus a boat identifier ( $b$ or $f$ ). 

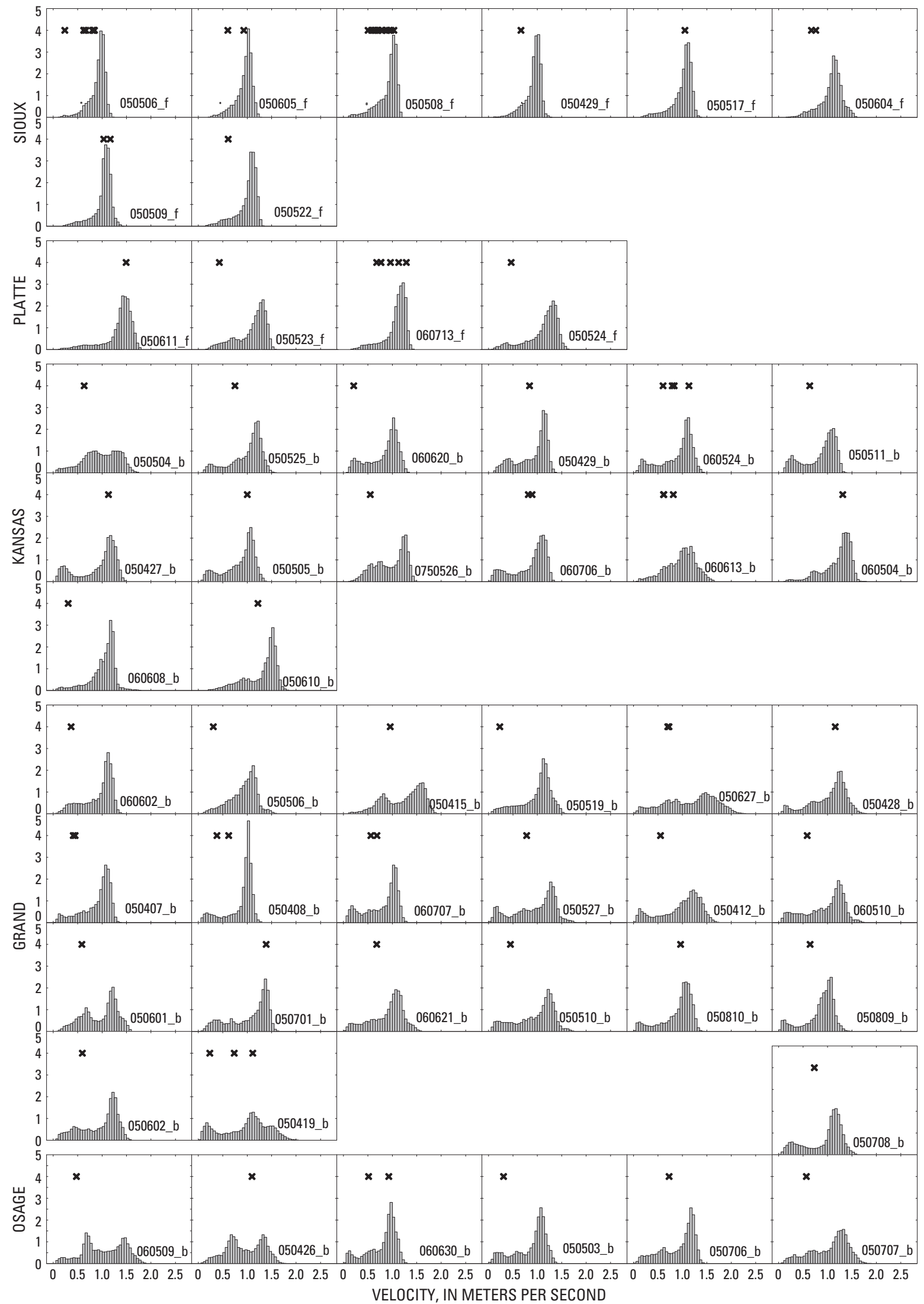

Figure 16. Histograms of velocity maps for each reach with points representing sturgeon relocations. Histograms are ordered in descending order by river mile. The identification code includes the last two digits of the year, the twodigit month, and two-digit day of the month, plus a boat identifier ( $b$ or $f$ ).-Continued 
42 Assessment of Lower Missouri River Physical Aquatic Habitat and Its Use by Adult Sturgeon (Genus Scaphirhynchus), 2005-07
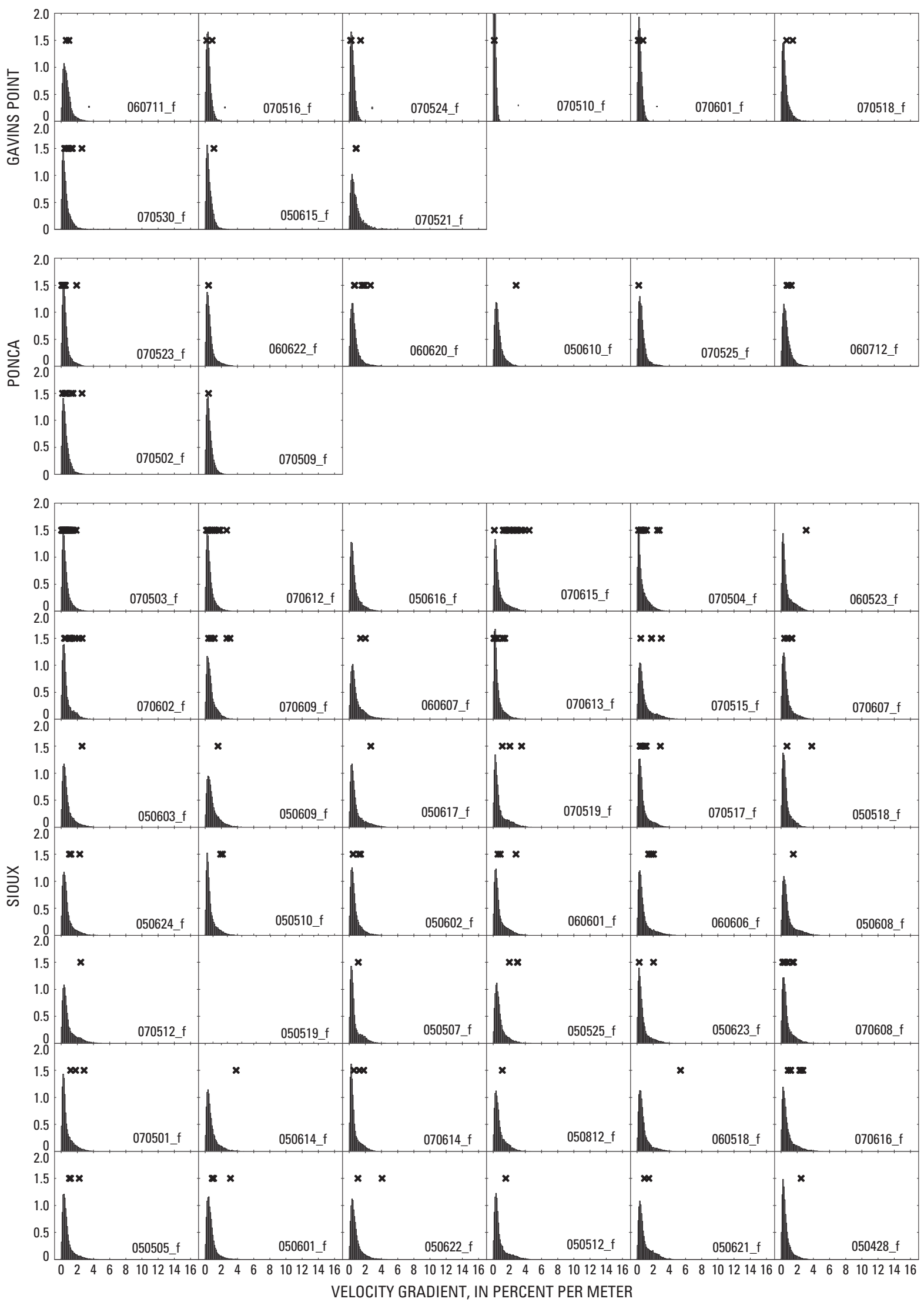

Figure 17. Histograms of velocity gradient maps for each reach with points representing sturgeon relocations. Histograms are ordered in descending order by river mile. The identification code includes the last two digits of the year, the two-digit month, and two-digit day of the month, plus a boat identifier ( $b$ or $\mathrm{f}$ ). 


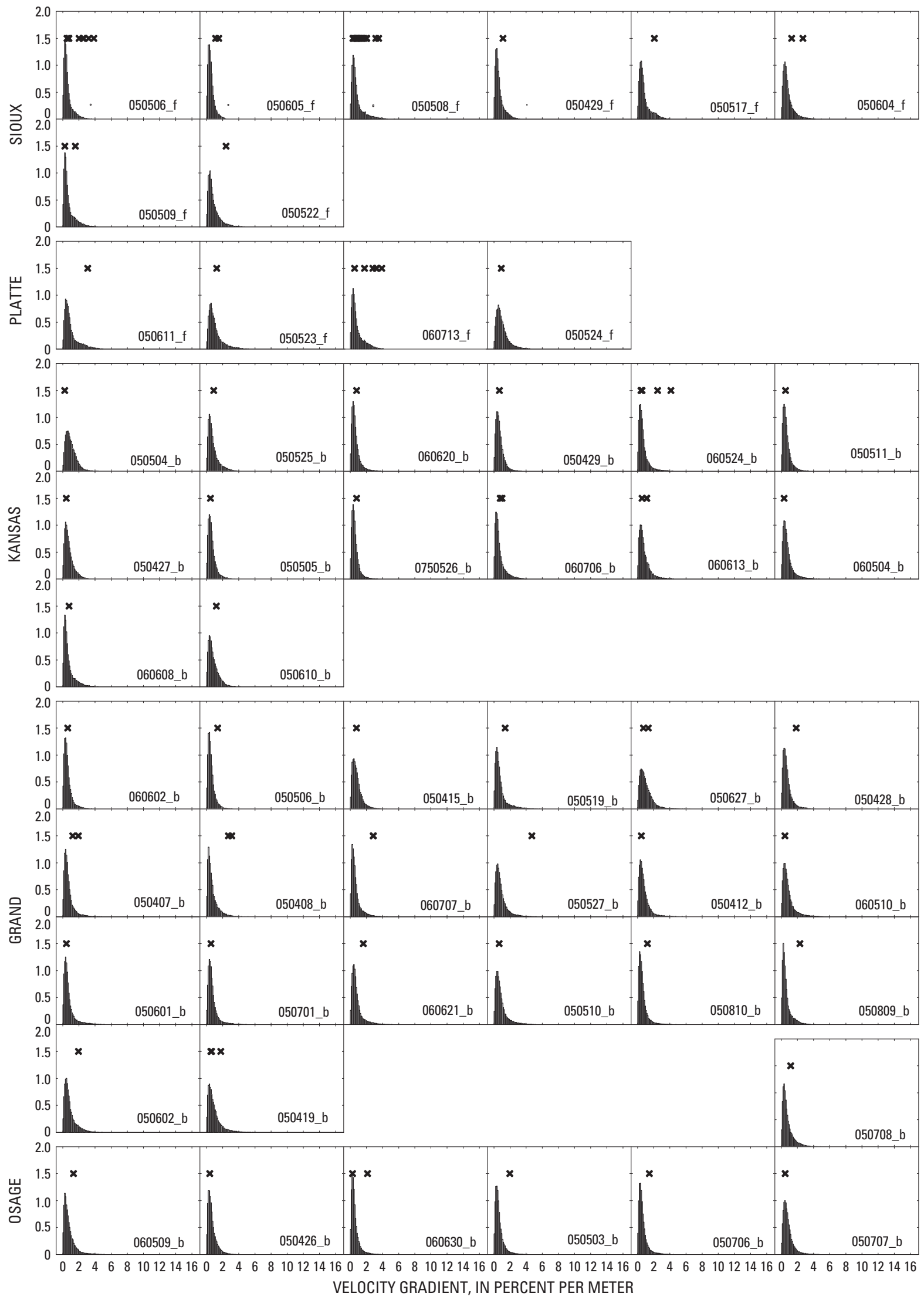

Figure 17. Histograms of velocity gradient maps for each reach with points representing sturgeon relocations. Histograms are ordered in descending order by river mile. The identification code includes the last two digits of the year, the two-digit month, and two-digit day of the month, plus a boat identifier ( $b$ or $f$ ).-Continued 

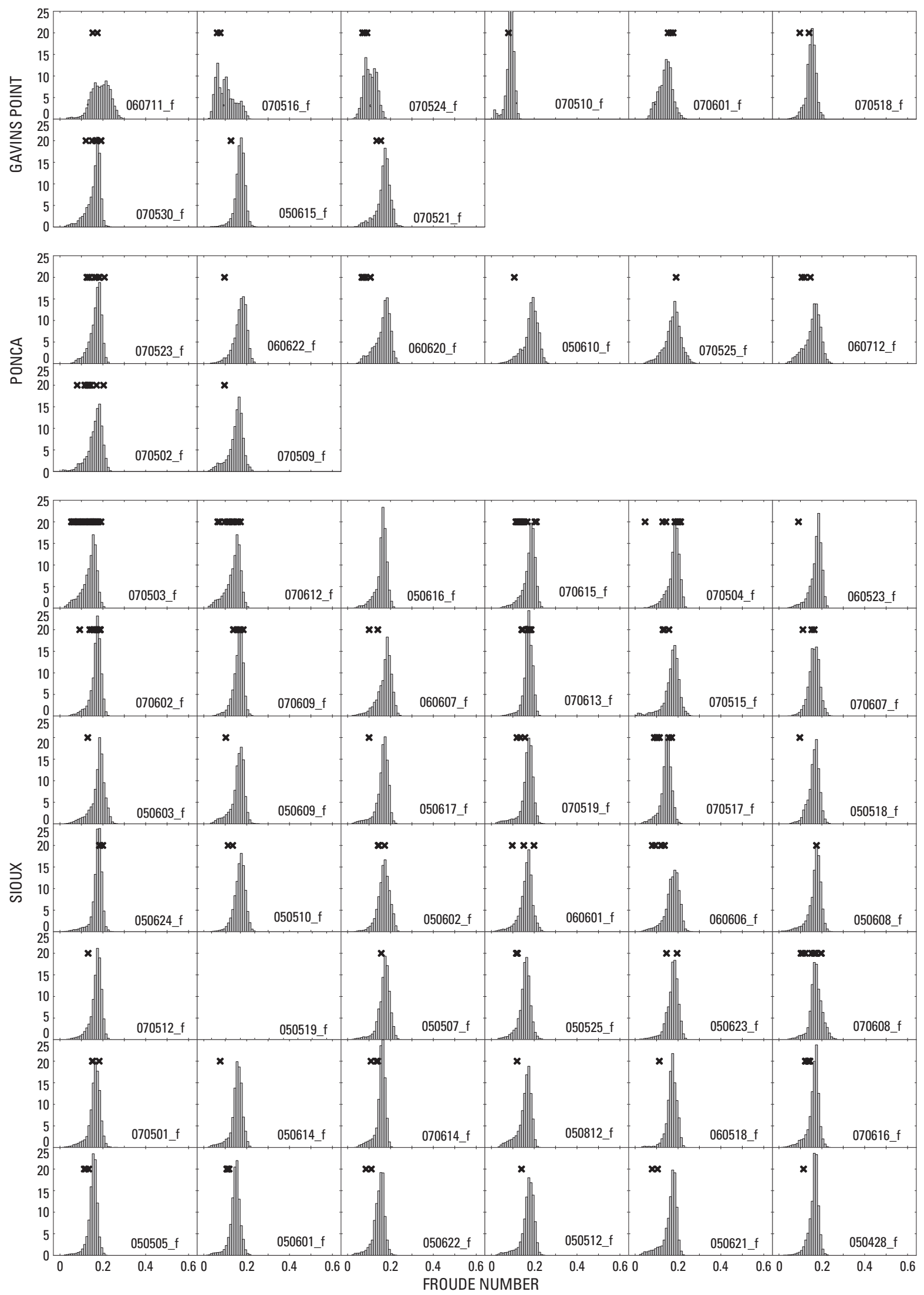

Figure 18. Histograms of Froude number maps for each reach with points representing sturgeon relocations. Histograms are ordered in descending order by river mile. The identification code includes the last two digits of the year, the two-digit month, and two-digit day of the month, plus a boat identifier ( $\mathrm{b}$ or $\mathrm{f}$ ). 

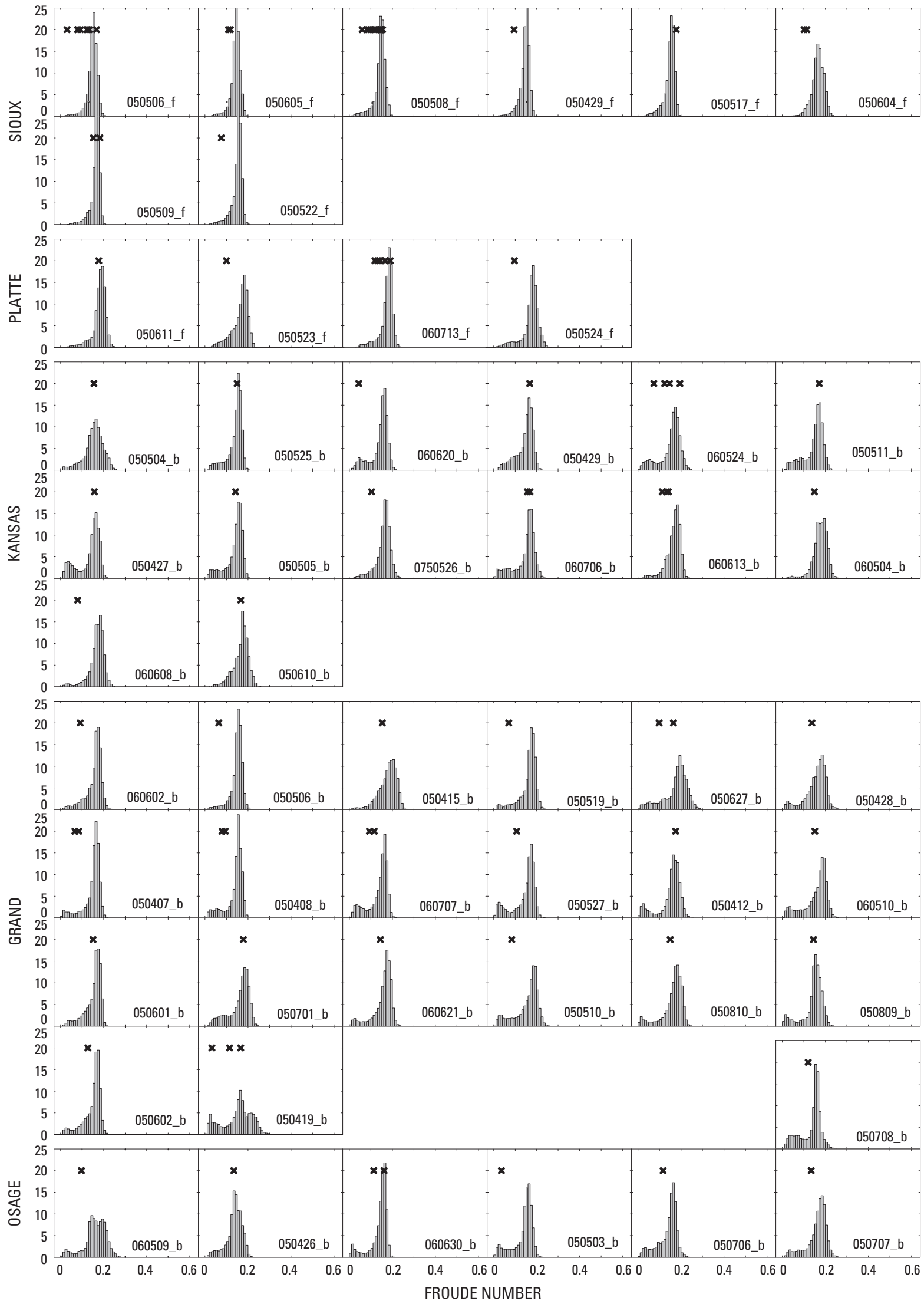

Figure 18. Histograms of Froude number maps for each reach with points representing sturgeon relocations. Histograms are ordered in descending order by river mile. The identification code includes the last two digits of the year, the two-digit month, and two-digit day of the month, plus a boat identifier ( $\mathrm{b}$ or $\mathrm{f}$ ).-Continued 

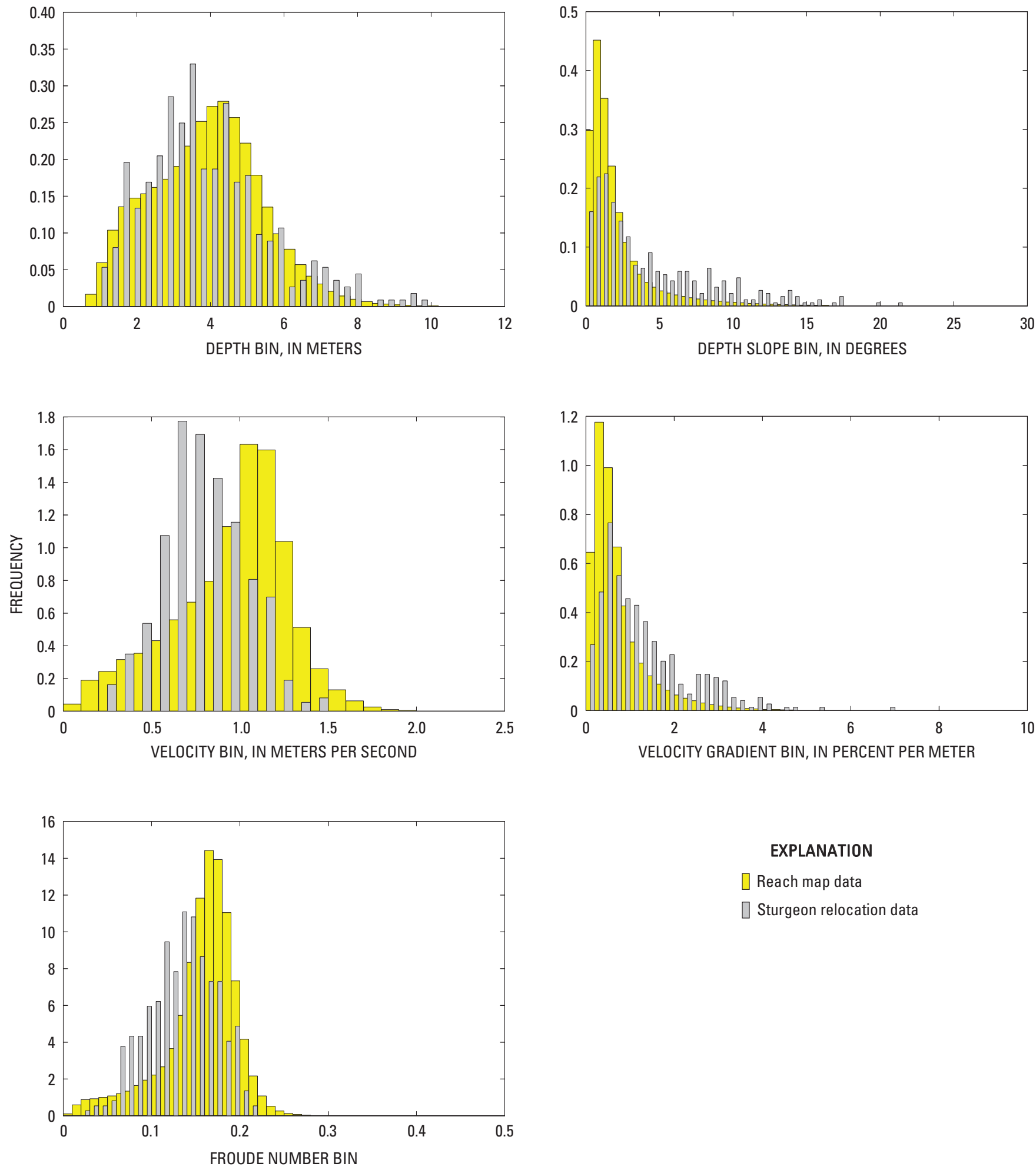

EXPLANATION

$\square$ Reach map data

$\square$ Sturgeon relocation data

Figure 19. Composite histograms of reach map data and values at qualifying sturgeon relocations (within 7 days and 10 percent discharge of the map from which values were obtained). Histograms for reach maps are based on the set of maps that included qualifying sturgeon relocations. All histograms have been normalized to have equal area. These histograms represent a composite of reach map data and sturgeon relocation data from all river sections and should be interpreted with caution. 

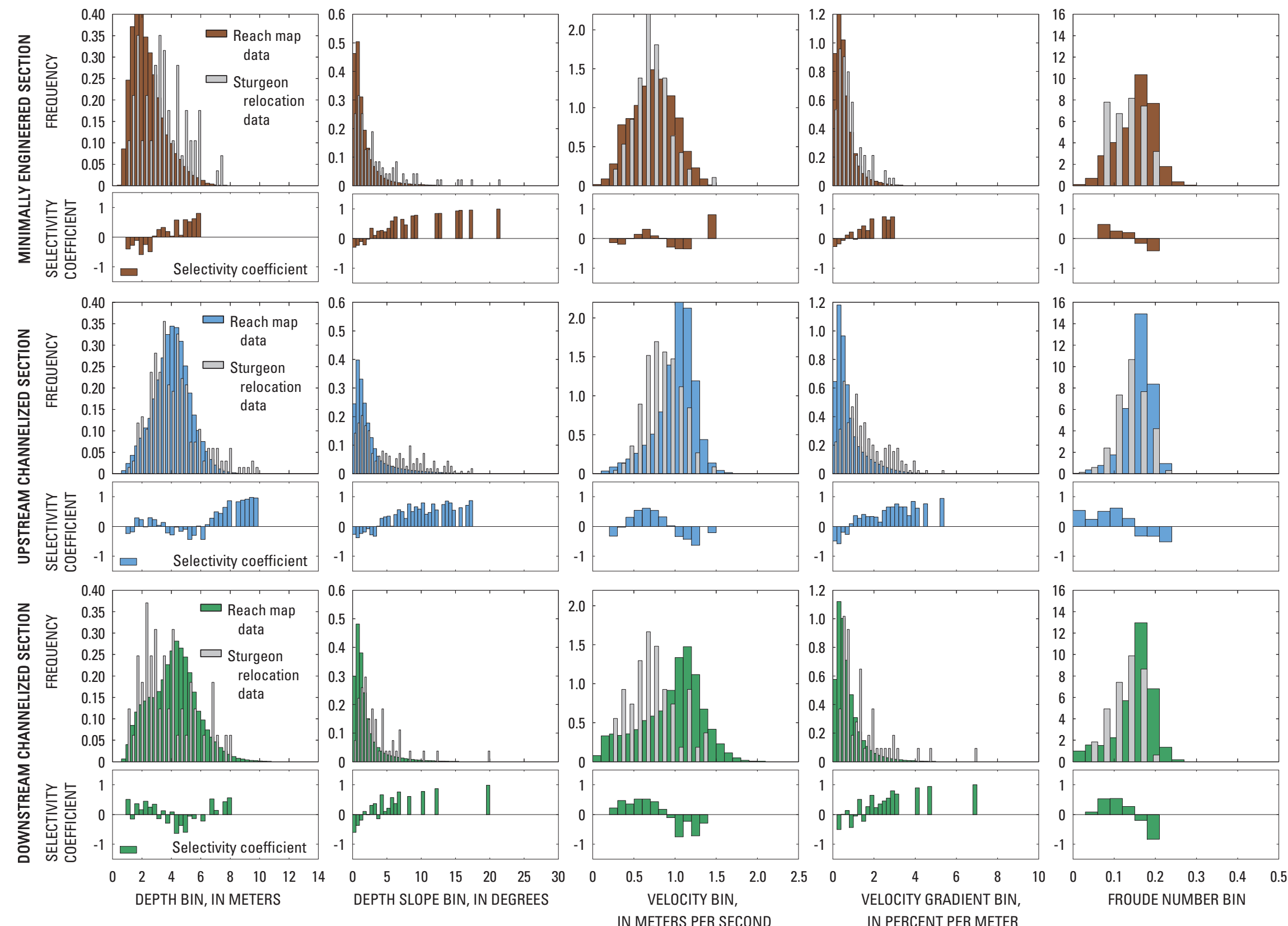

Figure 20. Histograms and Ivlev's selectivity coefficients for reach maps and qualifying sturgeon relocations, subdivided by river section. Histograms of values at sturgeon relocations (within 7 days and 10 percent discharge of the map from which values were obtained) with overall compiled histograms for all maps, subdivided by section. All histograms have been normalized to have equal area. Selectivity coefficients are shown for bins with at least one sturgeon relocation. 
Table 5. Number of relocations by decile for continuous and categorical variables compiled by sturgeon species, sex, reproductive condition, and river section.-Continued [Only river sections with data for a given combination of species, sex, and reproductive condition are shown. Repro., reproductive; Nonrepro., nonreproductive; Min. Eng., Minimally Engineered section; Up Chan., Upstream Channelized section; Down Chan., Downstream Channelized section]

\begin{tabular}{|c|c|c|c|c|c|c|c|c|c|c|c|c|c|c|c|c|c|c|c|c|c|c|c|}
\hline \multirow{4}{*}{$\begin{array}{c}\text { Decile range } \\
\text { or category }\end{array}$} & \multicolumn{11}{|c|}{ Number of locations for pallid sturgeon } & \multicolumn{12}{|c|}{ Number of locations for shovelnose sturgeon } \\
\hline & \multicolumn{5}{|c|}{ Female } & \multicolumn{5}{|c|}{ Male } & \multirow{3}{*}{$\begin{array}{c}\text { Pallid } \\
\text { sturgeon } \\
\text { total }\end{array}$} & \multicolumn{5}{|c|}{ Female } & \multirow{2}{*}{\multicolumn{2}{|c|}{$\begin{array}{l}\text { Intersex } \\
\text { Intersex }\end{array}$}} & \multicolumn{4}{|c|}{ Male } & \multirow{3}{*}{$\begin{array}{c}\text { Shovelnose } \\
\text { sturgeon } \\
\text { total }\end{array}$} \\
\hline & \multicolumn{2}{|c|}{$\begin{array}{c}\text { Repro. } \\
\text { unknown }\end{array}$} & \multirow{2}{*}{$\begin{array}{c}\begin{array}{c}\text { Non- } \\
\text { repro. }\end{array} \\
\text { Down } \\
\text { Chan. }\end{array}$} & \multicolumn{2}{|c|}{ Repro. } & \multirow{2}{*}{ 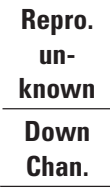 } & \multicolumn{2}{|c|}{ Nonrepro. } & \multicolumn{2}{|c|}{ Repro. } & & \multicolumn{2}{|c|}{ Nonrepro. } & \multicolumn{3}{|c|}{ Repro. } & & & \multicolumn{2}{|c|}{ Nonrepro. } & \multicolumn{2}{|c|}{ Repro. } & \\
\hline & $\begin{array}{l}\text { Min. } \\
\text { Eng. }\end{array}$ & $\begin{array}{l}\text { Down } \\
\text { Chan. }\end{array}$ & & $\begin{array}{l}\text { Min. } \\
\text { Eng. }\end{array}$ & $\begin{array}{c}\text { Up } \\
\text { Chan. }\end{array}$ & & $\begin{array}{c}\text { Up } \\
\text { Chan. }\end{array}$ & $\begin{array}{l}\text { Down } \\
\text { Chan. }\end{array}$ & $\begin{array}{c}\text { Up } \\
\text { Chan. }\end{array}$ & $\begin{array}{l}\text { Down } \\
\text { Chan. }\end{array}$ & & $\begin{array}{l}\text { Min. } \\
\text { Eng. }\end{array}$ & $\begin{array}{c}\text { Up } \\
\text { Chan. }\end{array}$ & $\begin{array}{l}\text { Min. } \\
\text { Eng. }\end{array}$ & $\begin{array}{l}\text { Up } \\
\text { Chan. }\end{array}$ & $\begin{array}{l}\text { Down } \\
\text { Chan. }\end{array}$ & $\begin{array}{l}\text { Min. } \\
\text { Eng. }\end{array}$ & $\begin{array}{c}\text { Up } \\
\text { Chan. }\end{array}$ & $\begin{array}{l}\text { Min. } \\
\text { Eng. }\end{array}$ & $\begin{array}{l}\text { Up } \\
\text { Chan. }\end{array}$ & $\begin{array}{l}\text { Min. } \\
\text { Eng. }\end{array}$ & $\begin{array}{c}\text { Up } \\
\text { Chan. }\end{array}$ & \\
\hline \multicolumn{24}{|c|}{ Depth decile } \\
\hline Minimum to 1 & -- & 1 & -- & -- & -- & 1 & -- & -- & -- & -- & 2 & 1 & 4 & 2 & 18 & 9 & -- & -- & -- & -- & -- & -- & 34 \\
\hline 1 to 2 & -- & 1 & 1 & -- & 2 & -- & -- & -- & -- & -- & 4 & 3 & 1 & 4 & 23 & 4 & -- & 1 & -- & 2 & 1 & 2 & 41 \\
\hline 2 to 3 & -- & -- & -- & -- & -- & -- & 1 & -- & 2 & 1 & 4 & 2 & 2 & 2 & 15 & 6 & -- & -- & -- & 1 & 2 & 1 & 31 \\
\hline 3 to 4 & -- & -- & -- & -- & -- & 2 & -- & 1 & -- & 1 & 4 & 2 & 3 & 3 & 4 & 4 & -- & -- & -- & -- & -- & -- & 16 \\
\hline 4 to 5 & -- & -- & -- & -- & -- & -- & 1 & 1 & 2 & -- & 4 & 1 & 1 & 2 & 12 & 5 & -- & -- & -- & -- & 2 & 1 & 24 \\
\hline 5 to 6 & -- & -- & -- & -- & -- & -- & -- & -- & -- & -- & -- & -- & 1 & 4 & 13 & 1 & -- & -- & -- & 2 & -- & 2 & 23 \\
\hline 6 to 7 & 1 & 1 & -- & -- & -- & -- & -- & -- & 1 & -- & 3 & 2 & -- & 5 & 14 & 1 & -- & -- & 1 & 1 & -- & 1 & 25 \\
\hline 7 to 8 & -- & 1 & -- & 1 & -- & 1 & -- & 1 & 5 & -- & 9 & -- & 1 & 7 & 15 & 2 & -- & -- & -- & -- & 1 & 1 & 27 \\
\hline 8 to 9 & 1 & -- & -- & -- & -- & -- & 2 & -- & -- & -- & 3 & 2 & -- & 8 & 19 & 2 & -- & -- & -- & -- & 3 & 2 & 36 \\
\hline 9 to maximum & -- & -- & -- & 1 & -- & 2 & -- & 1 & -- & 1 & 5 & 5 & 4 & 20 & 39 & 2 & 2 & -- & -- & 1 & 4 & 2 & 79 \\
\hline \multicolumn{24}{|c|}{ Depth slope decile } \\
\hline Minimum to 1 & -- & 1 & -- & -- & -- & 1 & -- & -- & 1 & -- & 3 & -- & 1 & -- & 6 & -- & -- & -- & -- & -- & -- & -- & 7 \\
\hline 1 to 2 & -- & -- & -- & -- & -- & -- & -- & -- & 2 & -- & 2 & 1 & 2 & 2 & 7 & 1 & -- & -- & -- & -- & 1 & 1 & 15 \\
\hline 2 to 3 & -- & -- & -- & -- & -- & -- & -- & -- & -- & 1 & 1 & 4 & 2 & 4 & 8 & 2 & -- & 1 & -- & -- & 3 & -- & 24 \\
\hline 3 to 4 & 1 & -- & -- & -- & -- & -- & -- & -- & -- & -- & 1 & 2 & 2 & 5 & 5 & 3 & -- & -- & -- & 1 & 1 & 1 & 20 \\
\hline 4 to 5 & -- & -- & -- & 1 & -- & 1 & -- & -- & 6 & -- & 8 & 2 & -- & 2 & 9 & 4 & -- & -- & -- & -- & 1 & 2 & 20 \\
\hline 5 to 6 & 1 & -- & -- & -- & -- & -- & 1 & 1 & -- & -- & 3 & -- & -- & 3 & 8 & 4 & -- & -- & -- & -- & -- & -- & 15 \\
\hline 6 to 7 & -- & -- & -- & 1 & -- & -- & -- & 1 & -- & -- & 2 & 3 & 3 & 5 & 21 & 4 & -- & -- & 1 & -- & -- & 2 & 39 \\
\hline 7 to 8 & -- & 1 & -- & -- & -- & -- & -- & -- & -- & -- & 1 & 3 & 2 & 8 & 15 & 3 & -- & -- & -- & -- & 2 & -- & 33 \\
\hline 8 to 9 & -- & 2 & -- & -- & 1 & 1 & -- & -- & -- & -- & 4 & -- & -- & 12 & 21 & 8 & -- & -- & -- & 2 & 4 & 2 & 49 \\
\hline 9 to maximum & -- & -- & 1 & -- & 1 & 3 & 3 & 2 & 1 & 2 & 13 & 3 & 5 & 16 & 72 & 7 & 2 & -- & -- & 4 & 1 & 4 & 114 \\
\hline & & & & & & & & & & Terrain & class cate & & & & & & & & & & & & \\
\hline Flat & 2 & -- & -- & 1 & -- & 2 & -- & -- & 7 & 1 & 13 & 7 & 5 & 15 & 34 & 8 & -- & -- & -- & 1 & 2 & 5 & 77 \\
\hline Slope & -- & -- & -- & -- & -- & -- & 1 & 1 & 1 & -- & 3 & -- & -- & 4 & 16 & 2 & -- & -- & -- & 2 & -- & 1 & 25 \\
\hline Crest & -- & 2 & 1 & -- & 2 & 2 & 1 & 2 & 2 & 1 & 13 & 4 & 8 & 6 & 51 & 21 & -- & 1 & -- & 2 & 3 & 2 & 98 \\
\hline Depression & -- & 2 & -- & 1 & -- & 2 & 2 & 1 & -- & 1 & 9 & 7 & 4 & 32 & 71 & 5 & 2 & -- & 1 & 2 & 8 & 4 & 136 \\
\hline
\end{tabular}


Table 5. Number of relocations by decile for continuous and categorical variables compiled by sturgeon species, sex, reproductive condition, and river section.-Continued [Only river sections with data for a given combination of species, sex, and reproductive condition are shown. Repro., reproductive; Nonrepro., nonreproductive; Min. Eng., Minimally Engineered section; Up Chan., Upstream Channelized section; Down Chan., Downstream Channelized section]

\begin{tabular}{|c|c|c|c|c|c|c|c|c|c|c|c|c|c|c|c|c|c|c|c|c|c|c|c|}
\hline \multirow{4}{*}{$\begin{array}{l}\text { Decile range } \\
\text { or category }\end{array}$} & \multicolumn{11}{|c|}{ Number of locations for pallid sturgeon } & \multicolumn{12}{|c|}{ Number of locations for shovelnose sturgeon } \\
\hline & \multicolumn{5}{|c|}{ Female } & \multicolumn{5}{|c|}{ Male } & \multirow{3}{*}{$\begin{array}{c}\text { Pallid } \\
\text { sturgeon } \\
\text { total } \\
\end{array}$} & \multicolumn{5}{|c|}{ Female } & \multirow{2}{*}{\multicolumn{2}{|c|}{$\begin{array}{c}\text { Intersex } \\
\text { Intersex }\end{array}$}} & \multicolumn{4}{|c|}{ Male } & \multirow{3}{*}{$\begin{array}{c}\text { Shovelnose } \\
\text { sturgeon } \\
\text { total }\end{array}$} \\
\hline & \multicolumn{2}{|c|}{$\begin{array}{c}\text { Repro. } \\
\text { unknown }\end{array}$} & \multirow{2}{*}{$\begin{array}{l}\begin{array}{c}\text { Non- } \\
\text { repro. }\end{array} \\
\text { Down } \\
\text { Chan. }\end{array}$} & \multicolumn{2}{|c|}{ Repro. } & \multirow{2}{*}{$\begin{array}{c}\begin{array}{c}\text { Repro. } \\
\text { un- } \\
\text { known }\end{array} \\
\text { Down } \\
\text { Chan. }\end{array}$} & \multicolumn{2}{|c|}{ Nonrepro. } & \multicolumn{2}{|c|}{ Repro. } & & \multicolumn{2}{|c|}{ Nonrepro. } & \multicolumn{3}{|c|}{ Repro. } & & & \multicolumn{2}{|c|}{ Nonrepro. } & & epro. & \\
\hline & $\begin{array}{l}\text { Min. } \\
\text { Eng. }\end{array}$ & $\begin{array}{l}\text { Down } \\
\text { Chan. }\end{array}$ & & $\begin{array}{l}\text { Min. } \\
\text { Eng. }\end{array}$ & $\begin{array}{c}\text { Up } \\
\text { Chan. }\end{array}$ & & $\begin{array}{c}\text { Up } \\
\text { Chan. }\end{array}$ & $\begin{array}{l}\text { Down } \\
\text { Chan. }\end{array}$ & $\begin{array}{l}\text { Up } \\
\text { Chan. }\end{array}$ & $\begin{array}{l}\text { Down } \\
\text { Chan. }\end{array}$ & & $\begin{array}{l}\text { Min. } \\
\text { Eng. }\end{array}$ & $\begin{array}{c}\text { Up } \\
\text { Chan. }\end{array}$ & $\begin{array}{l}\text { Min. } \\
\text { Eng. }\end{array}$ & $\begin{array}{l}\text { Up } \\
\text { Chan. }\end{array}$ & $\begin{array}{l}\text { Down } \\
\text { Chan. }\end{array}$ & $\begin{array}{l}\text { Min. } \\
\text { Eng. }\end{array}$ & $\begin{array}{l}\text { Up } \\
\text { Chan. }\end{array}$ & $\begin{array}{l}\text { Min. } \\
\text { Eng. }\end{array}$ & $\begin{array}{c}\text { Up } \\
\text { Chan. }\end{array}$ & $\begin{array}{l}\text { Min. } \\
\text { Eng. }\end{array}$ & $\begin{array}{c}\text { Up } \\
\text { Chan. }\end{array}$ & \\
\hline & & & & & & & & & & & locity decile & & & & & & & & & & & & \\
\hline Minimum to 1 & -- & -- & 1 & -- & -- & -- & -- & -- & -- & -- & 1 & 2 & 5 & 9 & 42 & 5 & -- & 1 & -- & -- & 1 & 3 & 68 \\
\hline 1 to 2 & -- & 1 & -- & -- & 2 & 3 & -- & -- & 1 & 1 & 8 & -- & 2 & 7 & 41 & 11 & -- & -- & -- & 1 & 1 & 3 & 66 \\
\hline 2 to 3 & -- & 1 & -- & 1 & -- & 1 & 1 & 1 & -- & -- & 5 & 5 & 3 & 7 & 37 & 9 & 1 & -- & -- & 3 & 1 & 3 & 69 \\
\hline 3 to 4 & 1 & -- & -- & -- & -- & 1 & -- & 2 & -- & -- & 4 & 2 & -- & 8 & 11 & 6 & 1 & -- & -- & 1 & 1 & -- & 30 \\
\hline 4 to 5 & -- & -- & -- & -- & -- & -- & 1 & -- & -- & -- & 1 & 2 & 2 & 7 & 7 & 1 & -- & -- & -- & -- & -- & -- & 19 \\
\hline 5 to 6 & -- & 2 & -- & 1 & -- & -- & -- & -- & -- & 2 & 5 & 1 & -- & 3 & 2 & 4 & -- & -- & -- & 1 & 2 & -- & 13 \\
\hline 6 to 7 & -- & -- & -- & -- & -- & -- & -- & -- & 2 & -- & 2 & 3 & 3 & 5 & 11 & -- & -- & -- & 1 & 1 & 1 & 2 & 27 \\
\hline 7 to 8 & 1 & -- & -- & -- & -- & -- & 1 & 1 & 1 & -- & 4 & 1 & -- & 2 & 5 & -- & -- & -- & -- & -- & 1 & -- & 9 \\
\hline 8 to 9 & -- & -- & -- & -- & -- & 1 & -- & -- & -- & -- & 1 & 2 & 1 & 4 & 7 & -- & -- & -- & -- & -- & 1 & -- & 15 \\
\hline 9 to maximum & -- & -- & -- & -- & -- & -- & 1 & -- & 6 & -- & 7 & -- & 1 & 4 & 8 & -- & -- & -- & -- & -- & 4 & 1 & 18 \\
\hline & & & & & & & & & & Velocity & gradient $\mathrm{d}$ & ecile & & & & & & & & & & & \\
\hline Minimum to 1 & -- & -- & -- & -- & -- & -- & -- & -- & -- & -- & -- & 2 & -- & 1 & 6 & 1 & -- & -- & -- & -- & -- & -- & 10 \\
\hline 1 to 2 & -- & -- & -- & -- & -- & -- & -- & -- & -- & -- & -- & 2 & 1 & 5 & 3 & -- & -- & -- & -- & -- & 3 & 1 & 15 \\
\hline 2 to 3 & -- & -- & -- & -- & -- & -- & -- & -- & 1 & 1 & 2 & 3 & 1 & 3 & 6 & 1 & -- & -- & -- & -- & -- & -- & 14 \\
\hline 3 to 4 & -- & 2 & -- & -- & -- & -- & -- & 1 & -- & -- & 3 & -- & 2 & 3 & 6 & 3 & -- & -- & -- & -- & -- & -- & 14 \\
\hline 4 to 5 & -- & -- & -- & -- & -- & -- & 1 & -- & -- & -- & 1 & 3 & 1 & 4 & 7 & 5 & -- & -- & -- & -- & 3 & 1 & 24 \\
\hline 5 to 6 & 1 & -- & -- & -- & -- & 2 & -- & 1 & 7 & -- & 11 & 2 & -- & 5 & 7 & 3 & 1 & -- & 1 & -- & 2 & -- & 21 \\
\hline 6 to 7 & -- & -- & -- & 2 & -- & -- & -- & -- & 1 & -- & 3 & 1 & 1 & 7 & 13 & 4 & -- & -- & -- & 2 & -- & 1 & 29 \\
\hline 7 to 8 & 1 & -- & 1 & -- & -- & -- & -- & -- & -- & -- & 2 & -- & -- & 7 & 26 & 6 & 1 & -- & -- & -- & 1 & 1 & 42 \\
\hline 8 to 9 & -- & 1 & -- & -- & 2 & -- & 1 & -- & -- & -- & 4 & 1 & 5 & 8 & 41 & 5 & -- & 1 & -- & -- & 1 & 3 & 65 \\
\hline 9 to maximum & -- & 1 & -- & -- & -- & 4 & 2 & 2 & 1 & 2 & 12 & 4 & 6 & 13 & 56 & 8 & -- & -- & -- & 5 & 3 & 5 & 100 \\
\hline & & & & & & & & & & Froude & number de & & & & & & & & & & & & \\
\hline Minimum to 1 & -- & -- & 1 & -- & -- & 1 & -- & -- & 1 & -- & 3 & 1 & 5 & 17 & 66 & 9 & 1 & 1 & -- & -- & 2 & 5 & 107 \\
\hline 1 to 2 & -- & -- & -- & 1 & -- & 2 & -- & 1 & -- & 1 & 5 & 6 & 3 & 14 & 39 & 7 & 1 & -- & -- & 5 & 2 & 3 & 80 \\
\hline 2 to 3 & 1 & 2 & -- & 1 & 1 & 2 & 2 & 1 & -- & 1 & 11 & 2 & 2 & 5 & 11 & 8 & -- & -- & -- & -- & 1 & 1 & 30 \\
\hline 3 to 4 & 1 & 1 & -- & -- & 1 & -- & -- & 1 & -- & -- & 4 & 3 & 1 & 6 & 7 & 4 & -- & -- & -- & -- & 1 & 1 & 23 \\
\hline 4 to 5 & -- & -- & -- & -- & -- & -- & -- & -- & -- & -- & -- & -- & -- & 5 & 10 & 3 & -- & -- & 1 & -- & 1 & -- & 20 \\
\hline 5 to 6 & -- & 1 & -- & -- & -- & 1 & -- & -- & -- & -- & 2 & 1 & -- & 2 & 10 & 2 & -- & -- & -- & 1 & -- & -- & 16 \\
\hline 6 to 7 & -- & -- & -- & -- & -- & -- & 1 & -- & -- & 1 & 2 & -- & -- & 4 & 6 & 3 & -- & -- & -- & -- & 1 & 1 & 15 \\
\hline 7 to 8 & -- & -- & -- & -- & -- & -- & -- & -- & 7 & -- & 7 & 1 & -- & 3 & 7 & -- & -- & -- & -- & -- & -- & 1 & 12 \\
\hline 8 to 9 & -- & -- & -- & -- & -- & -- & 1 & 1 & 1 & -- & 3 & 2 & 4 & -- & 8 & -- & -- & -- & -- & 1 & 1 & -- & 16 \\
\hline 9 to maximum & -- & -- & -- & -- & -- & -- & -- & -- & 1 & -- & 1 & 2 & 2 & -- & 5 & -- & -- & -- & -- & -- & 4 & -- & 13 \\
\hline
\end{tabular}


Table 5. Number of relocations by decile for continuous and categorical variables compiled by sturgeon species, sex, reproductive condition, and river section.-Continued [Only river sections with data for a given combination of species, sex, and reproductive condition are shown. Repro., reproductive; Nonrepro., nonreproductive; Min. Eng., Minimally Engineered section; Up Chan., Upstream Channelized section; Down Chan., Downstream Channelized section]

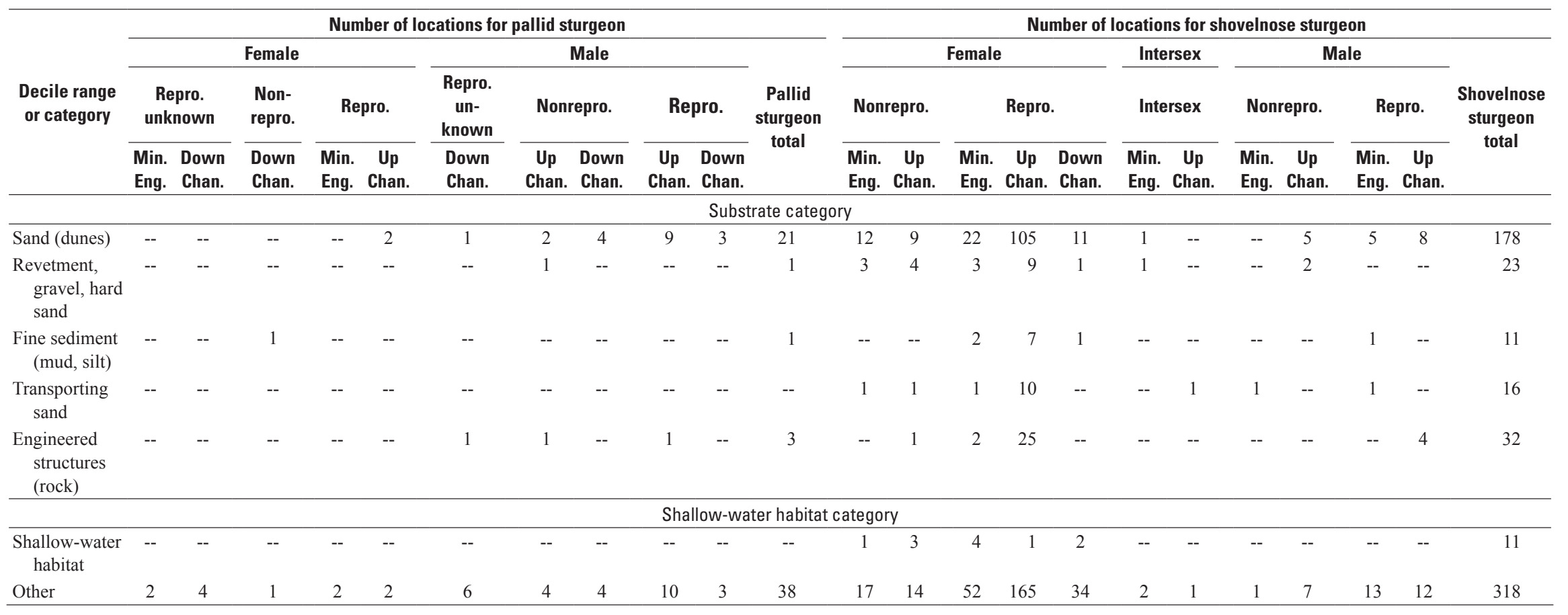



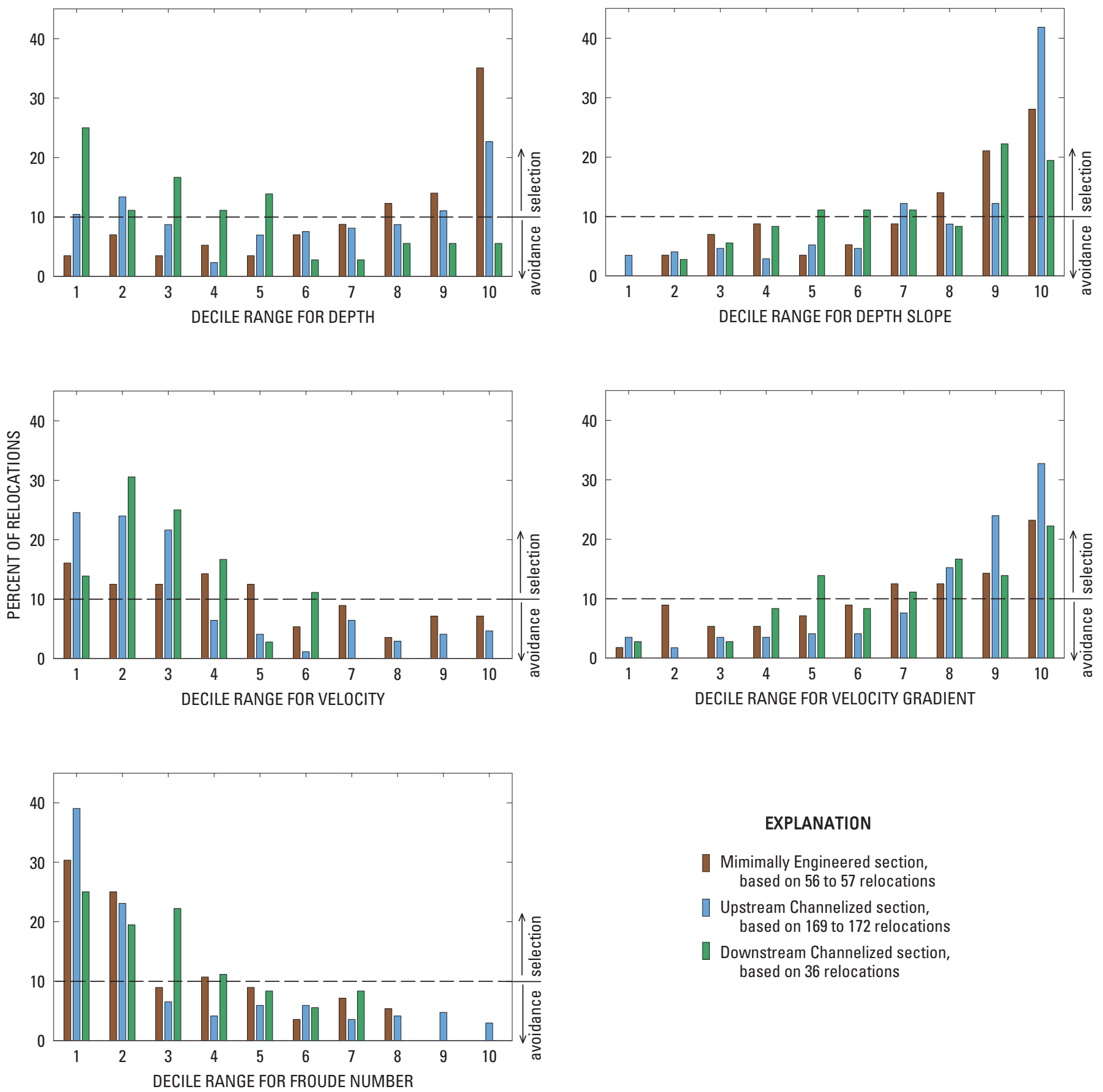

EXPLANATION

Mimimally Engineered section, based on 56 to 57 relocations

4. Upstream Channelized section, based on 169 to 172 relocations

Downstream Channelized section, based on 36 relocations

Figure 21. Plots of percentage of reproductive female shovelnose sturgeon in each decile range, by river section, for each continuous variable. 
Table 6. Number of relocations by decile for continuous variables for only reproductive female shovelnose sturgeon compiled by year.

[Min. eng., Minimally Engineered section; Up Chan., Upstream Channelized section; Down Chan., Downstream Channelized section; --, no data]

Number of female, reproductive shovelnose sturgeon relocations

\begin{tabular}{|c|c|c|c|c|c|c|c|c|c|c|c|c|c|c|c|c|c|c|c|c|}
\hline \multirow{2}{*}{ Decile range } & \multicolumn{4}{|c|}{ Depth } & \multicolumn{4}{|c|}{ Depth slope } & \multicolumn{4}{|c|}{ Velocity } & \multicolumn{4}{|c|}{ Velocity gradient } & \multicolumn{4}{|c|}{ Froude Number } \\
\hline & $\begin{array}{l}\text { Min. } \\
\text { Eng. }\end{array}$ & $\begin{array}{c}\text { Up } \\
\text { Chan. }\end{array}$ & $\begin{array}{l}\text { Down } \\
\text { Chan. }\end{array}$ & Total & $\begin{array}{l}\text { Min. } \\
\text { Eng. }\end{array}$ & $\begin{array}{c}\text { Up } \\
\text { Chan. }\end{array}$ & $\begin{array}{l}\text { Down } \\
\text { Chan. }\end{array}$ & Total & $\begin{array}{l}\text { Min. } \\
\text { Eng. }\end{array}$ & $\begin{array}{c}\text { Up } \\
\text { Chan. }\end{array}$ & $\begin{array}{l}\text { Down } \\
\text { Chan. }\end{array}$ & Total & $\begin{array}{l}\text { Min. } \\
\text { Eng. }\end{array}$ & $\begin{array}{c}\text { Up } \\
\text { Chan. }\end{array}$ & $\begin{array}{l}\text { Down } \\
\text { Chan. }\end{array}$ & Total & $\begin{array}{l}\text { Min. } \\
\text { Eng. }\end{array}$ & $\begin{array}{c}\text { Up } \\
\text { Chan. }\end{array}$ & $\begin{array}{l}\text { Down } \\
\text { Chan. }\end{array}$ & Total \\
\hline \multicolumn{21}{|c|}{2005} \\
\hline Minimum to 1 & 1 & 12 & 6 & 19 & 0 & 0 & 0 & 0 & 2 & 27 & 1 & 30 & 0 & 0 & 1 & 1 & 2 & 33 & 5 & 40 \\
\hline 1 to 2 & 0 & 11 & 4 & 15 & 0 & 3 & 1 & 4 & 0 & 16 & 9 & 25 & 0 & 0 & 0 & 0 & 0 & 19 & 2 & 21 \\
\hline 2 to 3 & 0 & 7 & 2 & 9 & 0 & 5 & 2 & 7 & 0 & 14 & 6 & 20 & 0 & 3 & 0 & 3 & 0 & 1 & 6 & 7 \\
\hline 3 to 4 & 0 & 1 & 2 & 3 & 1 & 2 & 1 & 4 & 0 & 4 & 3 & 7 & 0 & 1 & 3 & 4 & 0 & 2 & 4 & 6 \\
\hline 4 to 5 & 0 & 5 & 2 & 7 & 0 & 4 & 4 & 8 & 0 & 3 & 1 & 4 & 0 & 2 & 4 & 6 & 0 & 4 & 2 & 6 \\
\hline 5 to 6 & 0 & 2 & 1 & 3 & 0 & 0 & 2 & 2 & 0 & 0 & 3 & 3 & 0 & 3 & 3 & 6 & 0 & 3 & 1 & 4 \\
\hline 6 to 7 & 1 & 5 & 1 & 7 & 0 & 7 & 3 & 10 & 0 & 3 & 0 & 3 & 0 & 4 & 1 & 5 & 0 & 2 & 3 & 5 \\
\hline 7 to 8 & 0 & 5 & 2 & 7 & 0 & 8 & 1 & 9 & 0 & 1 & 0 & 1 & 0 & 13 & 3 & 16 & 0 & 1 & 0 & 1 \\
\hline 8 to 9 & 0 & 5 & 2 & 7 & 0 & 8 & 4 & 12 & 0 & 2 & 0 & 2 & 0 & 15 & 3 & 18 & 0 & 2 & 0 & 2 \\
\hline 9 to maximum & 0 & 18 & 1 & 19 & 1 & 34 & 5 & 40 & 0 & 1 & 0 & 1 & 2 & 30 & 5 & 37 & 0 & 3 & 0 & 3 \\
\hline \multicolumn{21}{|c|}{2006} \\
\hline Minimum to 1 & 0 & 1 & 3 & 4 & 0 & 0 & 0 & 0 & 3 & 5 & 4 & 12 & 0 & 0 & 0 & 0 & 7 & 10 & 4 & 21 \\
\hline 1 to 2 & 2 & 2 & 0 & 4 & 0 & 1 & 0 & 1 & 3 & 8 & 2 & 13 & 0 & 0 & 0 & 0 & 2 & 3 & 5 & 10 \\
\hline 2 to 3 & 1 & 2 & 4 & 7 & 1 & 1 & 0 & 2 & 1 & 0 & 3 & 4 & 0 & 0 & 1 & 1 & 0 & 1 & 2 & 3 \\
\hline 3 to 4 & 0 & 1 & 2 & 3 & 0 & 0 & 2 & 2 & 2 & 0 & 3 & 5 & 0 & 0 & 0 & 0 & 1 & 0 & 0 & 1 \\
\hline 4 to 5 & 1 & 1 & 3 & 5 & 0 & 1 & 0 & 1 & 0 & 0 & 0 & 0 & 1 & 0 & 1 & 2 & 0 & 0 & 1 & 1 \\
\hline 5 to 6 & 0 & 0 & 0 & 0 & 0 & 1 & 2 & 3 & 1 & 1 & 1 & 3 & 1 & 1 & 0 & 2 & 0 & 0 & 1 & 1 \\
\hline 6 to 7 & 1 & 1 & 0 & 2 & 0 & 0 & 1 & 1 & 0 & 1 & 0 & 1 & 2 & 0 & 3 & 5 & 0 & 0 & 0 & 0 \\
\hline 7 to 8 & 2 & 2 & 0 & 4 & 0 & 0 & 2 & 2 & 0 & 0 & 0 & 0 & 1 & 2 & 3 & 6 & 0 & 0 & 0 & 0 \\
\hline 8 to 9 & 0 & 3 & 0 & 3 & 4 & 1 & 4 & 9 & 0 & 0 & 0 & 0 & 1 & 5 & 2 & 8 & 0 & 0 & 0 & 0 \\
\hline 9 to maximum & 4 & 2 & 1 & 7 & 6 & 10 & 2 & 18 & 0 & 0 & 0 & 0 & 4 & 7 & 3 & 14 & 0 & 1 & 0 & 1 \\
\hline \multicolumn{21}{|c|}{2007} \\
\hline Minimum to 1 & 1 & 5 & -- & 6 & 0 & 6 & -- & 6 & 4 & 10 & -- & 14 & 1 & 6 & -- & 7 & 8 & 23 & -- & 31 \\
\hline 1 to 2 & 2 & 10 & -- & 12 & 2 & 3 & -- & 5 & 4 & 17 & -- & 21 & 5 & 3 & -- & 8 & 12 & 17 & -- & 29 \\
\hline 2 to 3 & 1 & 6 & -- & 7 & 3 & 2 & -- & 5 & 6 & 23 & -- & 29 & 3 & 3 & -- & 6 & 5 & 9 & -- & 14 \\
\hline 3 to 4 & 3 & 2 & -- & 5 & 4 & 3 & -- & 7 & 6 & 7 & -- & 13 & 3 & 5 & -- & 8 & 5 & 5 & -- & 10 \\
\hline 4 to 5 & 1 & 6 & -- & 7 & 2 & 4 & -- & 6 & 7 & 4 & -- & 11 & 3 & 5 & -- & 8 & 5 & 6 & -- & 11 \\
\hline 5 to 6 & 4 & 11 & -- & 15 & 3 & 7 & -- & 10 & 2 & 1 & -- & 3 & 4 & 3 & -- & 7 & 2 & 7 & -- & 9 \\
\hline 6 to 7 & 3 & 8 & -- & 11 & 5 & 14 & -- & 19 & 5 & 7 & -- & 12 & 5 & 9 & -- & 14 & 4 & 4 & -- & 8 \\
\hline 7 to 8 & 5 & 8 & -- & 13 & 8 & 7 & -- & 15 & 2 & 4 & -- & 6 & 6 & 11 & -- & 17 & 3 & 6 & -- & 9 \\
\hline 8 to 9 & 8 & 11 & -- & 19 & 8 & 12 & -- & 20 & 4 & 5 & -- & 9 & 7 & 21 & -- & 28 & 0 & 6 & -- & 6 \\
\hline 9 to maximum & 16 & 19 & -- & 35 & 9 & 28 & -- & 37 & 4 & 7 & -- & 11 & 7 & 19 & -- & 26 & 0 & 1 & -- & 1 \\
\hline
\end{tabular}


Table 7. Categorical variables summarized by reach, including numbers of qualifying sturgeon relocations within 10 percent discharge and 7 days of the map date.

[SWH, shallow-water habitat; --, no data]

\begin{tabular}{|c|c|c|c|c|c|c|c|c|c|c|c|c|c|c|c|c|c|c|c|c|c|c|c|}
\hline \multirow[b]{3}{*}{$\begin{array}{c}\text { Map } \\
\text { identification }\end{array}$} & \multirow[b]{3}{*}{$\begin{array}{l}\text { Reach } \\
\text { center } \\
\text { river } \\
\text { mile }\end{array}$} & \multicolumn{10}{|c|}{ Substrate } & \multicolumn{4}{|c|}{ Shallow-water habitat } & \multicolumn{8}{|c|}{ Terrain classification } \\
\hline & & \multicolumn{5}{|c|}{ Percent of map area } & \multicolumn{5}{|c|}{ Number of relocations } & \multicolumn{2}{|c|}{$\begin{array}{c}\text { Percent of } \\
\text { map area }\end{array}$} & \multicolumn{2}{|c|}{$\begin{array}{l}\text { Number of } \\
\text { relocations }\end{array}$} & \multicolumn{4}{|c|}{ Percent of map area } & \multicolumn{4}{|c|}{ Number of relocations } \\
\hline & & 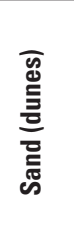 & 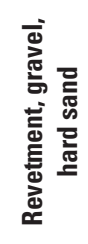 & 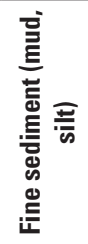 & 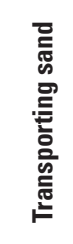 & 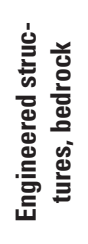 & 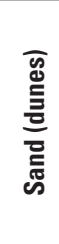 & 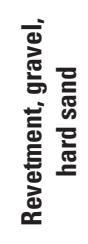 & 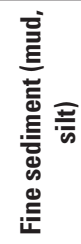 & 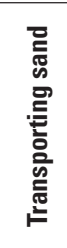 & 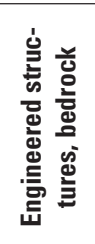 & 乿 & $\begin{array}{l}\frac{1}{3} \\
\text { 心 } \\
\text { to } \\
\text { zon }\end{array}$ & 予 & 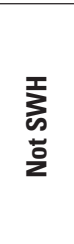 & $\frac{\pi}{\pi}$ & $\frac{\circ}{\omega}$ & 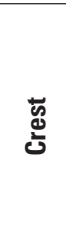 & 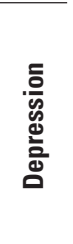 & $\frac{\pi}{4}$ & $\frac{0}{6}$ & 芯 & 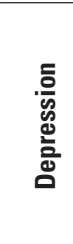 \\
\hline 20060711_f & 807.9 & -- & -- & -- & -- & -- & -- & -- & -- & -- & -- & 5.8 & 94.2 & 0 & 2 & 36.0 & 1.2 & 31.2 & 31.6 & 2 & 0 & 0 & 0 \\
\hline 20070516_f & 806.9 & -- & -- & -- & -- & -- & -- & -- & -- & -- & -- & 14.3 & 85.7 & 0 & 2 & 45.0 & 1.0 & 27.5 & 26.5 & 0 & 0 & 0 & 2 \\
\hline 20070524_f & 806.6 & -- & -- & -- & -- & -- & -- & -- & -- & -- & -- & 14.9 & 85.1 & 0 & 3 & 43.5 & 0.8 & 26.8 & 28.9 & 0 & 0 & 0 & 3 \\
\hline $20070510 \_f$ & 801.9 & -- & -- & -- & -- & -- & -- & -- & -- & -- & -- & 35.6 & 64.4 & 0 & 1 & 68.8 & 0.6 & 15.6 & 15.0 & 0 & 0 & 0 & 1 \\
\hline 20070601_f & 797.1 & -- & -- & -- & -- & -- & -- & -- & -- & -- & -- & 34.1 & 65.9 & 0 & 3 & 58.9 & 0.9 & 19.9 & 20.4 & 3 & 0 & 0 & 0 \\
\hline $20070518 \_f$ & 782.5 & -- & -- & -- & -- & -- & -- & -- & -- & -- & -- & 13.0 & 87.0 & 0 & 2 & 68.2 & 0.6 & 17.7 & 13.6 & 2 & 0 & 0 & 0 \\
\hline 20070530_f & 775.1 & -- & -- & -- & -- & -- & -- & -- & -- & -- & -- & 10.0 & 90.0 & 1 & 6 & 46.3 & 1.7 & 28.4 & 23.6 & 3 & 0 & 1 & 3 \\
\hline 20050615 f & 759.8 & -- & -- & -- & -- & -- & -- & -- & -- & -- & -- & 12.7 & 87.3 & 1 & 0 & 54.3 & 1.0 & 24.5 & 20.3 & 0 & 0 & 1 & 0 \\
\hline 20070521_f & 759.6 & -- & -- & -- & -- & -- & -- & -- & -- & -- & -- & 1.0 & 99.0 & 0 & 2 & 49.8 & 2.6 & 25.3 & 22.3 & 1 & 0 & 0 & 1 \\
\hline 20070523_f & 752.7 & -- & -- & -- & -- & -- & -- & -- & -- & -- & -- & 7.8 & 92.2 & 1 & 8 & 44.6 & 1.7 & 28.0 & 25.7 & 1 & 0 & 2 & 6 \\
\hline 20060622 f & 751.8 & 85.8 & 9.0 & 0.3 & 0.7 & 4.1 & 1 & 0 & 0 & 0 & 0 & 2.7 & 97.3 & 0 & 1 & 44.1 & 1.8 & 27.9 & 26.3 & 0 & 0 & 0 & 1 \\
\hline $20060620 \_\mathrm{f}$ & 749.3 & -- & -- & -- & -- & -- & -- & -- & -- & -- & -- & 5.8 & 94.2 & 1 & 5 & 40.3 & 1.9 & 33.5 & 24.2 & 1 & 0 & 3 & 3 \\
\hline 20050610_f & 746.3 & 78.1 & 5.1 & 0.6 & 15.6 & 0.6 & 1 & 0 & 0 & 0 & 0 & 0.8 & 99.2 & 0 & 1 & 29.4 & 2.3 & 39.4 & 28.8 & 0 & 1 & 0 & 0 \\
\hline 20070525 f & 745.0 & 79.7 & 17.1 & 0.4 & 2.6 & 0.4 & 1 & 0 & 0 & 0 & 0 & 6.8 & 93.2 & 0 & 1 & 30.3 & 2.0 & 40.5 & 27.1 & 1 & 0 & 0 & 0 \\
\hline 20060712_f & 743.7 & 80.1 & 13.0 & 1.6 & 2.2 & 3.1 & 2 & 1 & 0 & 0 & 0 & 5.4 & 94.6 & 0 & 3 & 27.9 & 3.1 & 41.1 & 27.9 & 0 & 2 & 0 & 1 \\
\hline $20070502 \_f$ & 738.2 & 81.7 & 5.5 & 5.7 & 5.6 & 1.6 & 6 & 1 & 2 & 0 & 0 & 7.9 & 92.1 & 0 & 9 & 44.4 & 2.1 & 30.8 & 22.7 & 3 & 0 & 1 & 5 \\
\hline 20070509_f & 736.6 & 85.8 & 4.9 & 4.4 & 4.0 & 0.8 & 4 & 0 & 1 & 0 & 0 & 16.1 & 83.9 & 0 & 5 & 40.8 & 1.9 & 33.4 & 23.9 & 1 & 0 & 1 & 3 \\
\hline 20070612_f & 734.2 & 84.7 & 3.1 & 1.1 & 8.3 & 2.8 & 11 & 1 & 0 & 1 & 3 & 1.5 & 98.5 & 1 & 14 & 36.1 & 2.3 & 35.8 & 25.7 & 6 & 1 & 4 & 5 \\
\hline 20070503_f & 734.2 & 77.7 & 5.9 & 8.4 & 5.0 & 3.0 & 41 & 10 & 0 & 4 & 1 & 9.3 & 90.7 & 0 & 58 & 37.2 & 2.5 & 35.1 & 25.2 & 15 & 1 & 6 & 36 \\
\hline 20050616_f & 732.4 & 80.2 & 2.1 & 1.2 & 13.2 & 3.4 & 0 & 0 & 0 & 0 & 0 & 0.3 & 99.7 & 0 & 0 & 48.2 & 2.6 & 23.8 & 25.4 & 0 & 0 & 0 & 1 \\
\hline 20070615 f & 729.5 & 83.4 & 3.4 & 0.6 & 8.9 & 3.7 & 9 & 1 & 0 & 0 & 7 & 1.9 & 98.1 & 2 & 16 & 44.8 & 2.2 & 25.8 & 27.2 & 5 & 2 & 4 & 7 \\
\hline 20070504_f & 726.5 & 79.6 & 4.5 & 0.7 & 11.8 & 3.4 & 11 & 1 & 0 & 0 & 2 & 1.1 & 98.9 & 0 & 14 & 48.6 & 2.2 & 25.1 & 24.1 & 9 & 1 & 3 & 1 \\
\hline 20060523 _f & 725.0 & 72.4 & 7.1 & 1.1 & 12.5 & 6.9 & 0 & 0 & 0 & 1 & 0 & 1.2 & 98.8 & 0 & 1 & 40.4 & 3.0 & 27.6 & 29.1 & 0 & 0 & 0 & 1 \\
\hline 20070602 f & 724.6 & 81.8 & 2.0 & 0.5 & 10.2 & 5.5 & 5 & 0 & 0 & 0 & 6 & 1.2 & 98.8 & 0 & 11 & 49.5 & 2.0 & 22.1 & 26.4 & 3 & 2 & 4 & 2 \\
\hline 20070609_f & 717.8 & 80.6 & 5.9 & 0.2 & 11.4 & 1.9 & 3 & 2 & 0 & 1 & 0 & 2.2 & 97.8 & 0 & 6 & 31.8 & 3.0 & 31.2 & 34.0 & 2 & 1 & 2 & 1 \\
\hline 20060607_f & 709.3 & 81.7 & 3.5 & 1.3 & 8.6 & 4.9 & 2 & 0 & 0 & 0 & 0 & 1.9 & 98.1 & 0 & 2 & 33.9 & 2.8 & 32.4 & 31.0 & 1 & 1 & 0 & 0 \\
\hline 20070613_f & 707.5 & 79.8 & 5.2 & 0.2 & 12.6 & 2.2 & 7 & 0 & 0 & 1 & 0 & 1.9 & 98.1 & 0 & 8 & 44.9 & 2.4 & 25.9 & 26.8 & 3 & 0 & 1 & 4 \\
\hline 20070515 f & 706.2 & -- & -- & -- & -- & -- & -- & -- & -- & -- & -- & 1.5 & 98.5 & 0 & 4 & 33.9 & 3.2 & 31.2 & 31.6 & 1 & 0 & 2 & 1 \\
\hline 20070607_f & 702.2 & 76.3 & 9.3 & 0.6 & 9.5 & 4.4 & 3 & 0 & 0 & 0 & 0 & 1.3 & 98.7 & 0 & 3 & 29.2 & 2.4 & 37.4 & 31.0 & 0 & 0 & 1 & 3 \\
\hline
\end{tabular}


Table 7. Categorical variables summarized by reach, including numbers of qualifying sturgeon relocations within 10 percent discharge and 7 days of the map date.-Continued

[SWH, shallow-water habitat; --, no data]

\begin{tabular}{|c|c|c|c|c|c|c|c|c|c|c|c|c|c|c|c|c|c|c|c|c|c|c|c|}
\hline \multirow[b]{3}{*}{$\begin{array}{c}\text { Map } \\
\text { identification }\end{array}$} & \multirow[b]{3}{*}{$\begin{array}{c}\text { Reach } \\
\text { center } \\
\text { river } \\
\text { mile }\end{array}$} & \multicolumn{10}{|c|}{ Substrate } & \multicolumn{4}{|c|}{ Shallow-water habitat } & \multicolumn{8}{|c|}{ Terrain classification } \\
\hline & & \multicolumn{5}{|c|}{ Percent of map area } & \multicolumn{5}{|c|}{ Number of relocations } & \multicolumn{2}{|c|}{$\begin{array}{c}\text { Percent of } \\
\text { map area }\end{array}$} & \multicolumn{2}{|c|}{$\begin{array}{c}\text { Number of } \\
\text { relocations }\end{array}$} & \multicolumn{4}{|c|}{ Percent of map area } & \multicolumn{4}{|c|}{ Number of relocations } \\
\hline & & 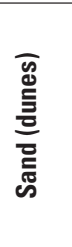 & 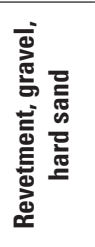 & 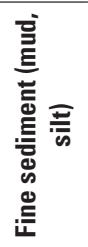 & 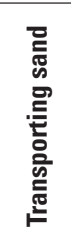 & 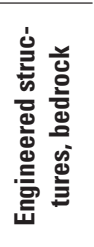 & 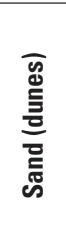 & 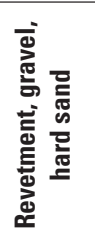 & 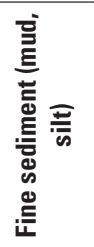 & 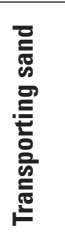 & 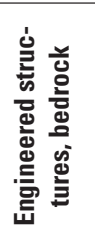 & 紊 & $\begin{array}{l}\frac{1}{3} \\
\text { s } \\
\frac{0}{2}\end{array}$ & 紊 & $\begin{array}{l}\frac{1}{3} \\
\text { s. } \\
\text { ᄒ⿱艹 }\end{array}$ & $\frac{\pi}{\frac{\pi}{4}}$ & $\frac{0}{\text { 호 }}$ & 范 & 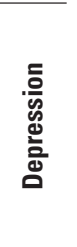 & $\frac{\pi}{4}$ & $\frac{\dddot{0}}{\infty}$ & 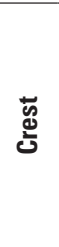 & 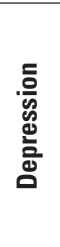 \\
\hline $20050603 \_f$ & 697.8 & 80.5 & 6.0 & 1.8 & 9.2 & 2.4 & 0 & 0 & 1 & 0 & 0 & 1.0 & 99.0 & 0 & 1 & 36.3 & 3.2 & 31.2 & 29.3 & 0 & 0 & 1 & 0 \\
\hline 20050609_f & 693.4 & 79.8 & 3.6 & 0.3 & 11.5 & 4.9 & 1 & 0 & 0 & 0 & 0 & 1.0 & 99.0 & 0 & 1 & 31.9 & 3.1 & 29.6 & 35.4 & 0 & 0 & 0 & 1 \\
\hline 20050617_f & 693.0 & 74.3 & 4.0 & 2.2 & 14.4 & 5.1 & 1 & 0 & 0 & 0 & 0 & 0.7 & 99.3 & 0 & 1 & 34.1 & 3.0 & 30.4 & 32.5 & 0 & 0 & 1 & 0 \\
\hline 20070519_f & 691.9 & 73.2 & 1.6 & 1.1 & 19.0 & 5.2 & 2 & 0 & 0 & 1 & 0 & 1.5 & 98.5 & 0 & 3 & 36.9 & 2.8 & 30.8 & 29.5 & 0 & 1 & 1 & 1 \\
\hline 20070517_f & 689.2 & -- & -- & -- & -- & -- & -- & -- & -- & -- & -- & 1.0 & 99.0 & 0 & 7 & 33.6 & 2.8 & 32.5 & 31.1 & 1 & 2 & 2 & 2 \\
\hline 20050518_f & 686.6 & 80.9 & 6.3 & 0.6 & 6.5 & 5.7 & 1 & 0 & 0 & 0 & 0 & 1.0 & 99.0 & 0 & 1 & 34.1 & 2.8 & 34.4 & 28.7 & 0 & 0 & 0 & 1 \\
\hline 20050624_f & 683.9 & 82.4 & 2.1 & 0.9 & 9.8 & 4.8 & 2 & 0 & 0 & 0 & 1 & 1.6 & 98.4 & 0 & 3 & 34.1 & 3.4 & 29.9 & 32.6 & 1 & 0 & 2 & 0 \\
\hline 20050510_f & 673.8 & 79.4 & 4.8 & 1.8 & 9.7 & 4.4 & 1 & 0 & 1 & 0 & 0 & 1.0 & 99.0 & 0 & 2 & 37.8 & 2.7 & 29.8 & 29.7 & 0 & 0 & 2 & 0 \\
\hline 20050602_f & 672.4 & 73.1 & 7.5 & 0.7 & 17.0 & 1.7 & 4 & 0 & 0 & 0 & 0 & 0.7 & 99.3 & 0 & 4 & 31.0 & 3.2 & 34.6 & 31.2 & 0 & 0 & 1 & 3 \\
\hline 20060601_f & 669.2 & 81.6 & 4.4 & 1.9 & 6.7 & 5.4 & 3 & 0 & 0 & 0 & 0 & 2.6 & 97.4 & 0 & 3 & 34.8 & 3.1 & 31.7 & 30.4 & 0 & 0 & 1 & 2 \\
\hline 20060606_f & 665.6 & 79.8 & 3.5 & 1.6 & 10.3 & 4.8 & 3 & 0 & 1 & 0 & 1 & 1.1 & 98.9 & 1 & 4 & 31.7 & 2.6 & 35.5 & 30.2 & 2 & 0 & 1 & 2 \\
\hline 20050608_f & 663.0 & 79.6 & 2.3 & 0.8 & 12.2 & 5.0 & 1 & 0 & 0 & 0 & 0 & 0.6 & 99.4 & 0 & 1 & 33.8 & 2.8 & 31.3 & 32.1 & 0 & 0 & 1 & 0 \\
\hline 20070512 f & 660.8 & -- & -- & -- & -- & -- & -- & -- & -- & -- & -- & 1.2 & 98.8 & 0 & 1 & 28.6 & 2.9 & 32.2 & 36.2 & 0 & 0 & 1 & 0 \\
\hline 20050519_f & 657.4 & -- & -- & -- & -- & -- & -- & -- & -- & -- & -- & -- & -- & -- & -- & 27.1 & 2.4 & 37.6 & 32.8 & 0 & 0 & 2 & 0 \\
\hline 20050507_f & 654.7 & 81.1 & 6.0 & 2.4 & 6.8 & 3.8 & 1 & 0 & 0 & 0 & 0 & 0.9 & 99.1 & 0 & 1 & 42.0 & 2.6 & 27.9 & 27.4 & 0 & 1 & 0 & 0 \\
\hline $20050525 \_\mathrm{f}$ & 652.0 & 80.4 & 3.7 & 2.1 & 8.8 & 5.0 & 1 & 0 & 0 & 0 & 2 & 0.0 & 100.0 & 0 & 3 & 29.5 & 3.4 & 35.2 & 32.0 & 0 & 0 & 3 & 0 \\
\hline 20050623 _f & 650.4 & 75.9 & 5.4 & 1.4 & 13.8 & 3.4 & 1 & 0 & 0 & 0 & 1 & 0.5 & 99.5 & 0 & 2 & 38.5 & 2.5 & 29.3 & 29.7 & 1 & 0 & 1 & 0 \\
\hline 20070608_f & 650.3 & 86.3 & 3.9 & 0.7 & 4.9 & 4.2 & 7 & 1 & 0 & 2 & 0 & 0.8 & 99.2 & 1 & 9 & 33.0 & 2.7 & 33.1 & 31.2 & 4 & 0 & 6 & 0 \\
\hline 20070501_f & 647.6 & 75.8 & 4.8 & 2.1 & 13.8 & 3.5 & 3 & 0 & 0 & 0 & 0 & 1.2 & 98.8 & 0 & 3 & 36.2 & 3.3 & 31.2 & 29.3 & 0 & 0 & 2 & 1 \\
\hline 20050614_f & 644.8 & 78.2 & 3.1 & 3.1 & 10.2 & 5.5 & 1 & 0 & 0 & 0 & 0 & 0.3 & 99.7 & 0 & 1 & 41.8 & 2.5 & 26.5 & 29.2 & 0 & 0 & 0 & 1 \\
\hline 20070614_f & 643.6 & 79.2 & 3.3 & 1.5 & 10.8 & 5.3 & 2 & 0 & 0 & 1 & 0 & 0.4 & 99.6 & 0 & 3 & 48.7 & 2.7 & 23.4 & 25.2 & 3 & 0 & 0 & 0 \\
\hline 20050812_f & 642.7 & -- & -- & -- & -- & -- & -- & -- & -- & -- & -- & 0.4 & 99.6 & 0 & 1 & 37.0 & 3.3 & 30.3 & 29.5 & 1 & 0 & 0 & 0 \\
\hline 20060518_f & 641.5 & 84.6 & 2.9 & 1.5 & 6.8 & 4.2 & 1 & 0 & 0 & 0 & 0 & 2.1 & 97.9 & 0 & 1 & 39.3 & 2.6 & 27.8 & 30.2 & 0 & 1 & 0 & 0 \\
\hline 20070616_f & 641.3 & 87.3 & 7.6 & 0.2 & 0.6 & 4.3 & 6 & 0 & 0 & 0 & 0 & 1.3 & 98.7 & 0 & 6 & 43.5 & 2.8 & 25.6 & 28.1 & 0 & 1 & 1 & 4 \\
\hline 20050505_f & 640.5 & 85.3 & 5.5 & 2.1 & 3.2 & 3.8 & 2 & 0 & 0 & 0 & 1 & 2.1 & 97.9 & 0 & 0 & 34.7 & 2.8 & 30.4 & 32.1 & 0 & 0 & 0 & 0 \\
\hline 20050601_f & 638.9 & 82.1 & 6.1 & 1.8 & 5.9 & 4.1 & 2 & 1 & 0 & 0 & 1 & 0.7 & 99.3 & 0 & 4 & 39.2 & 2.6 & 28.1 & 30.2 & 0 & 2 & 1 & 1 \\
\hline 20050622 f & 622.8 & 75.8 & 2.8 & 2.5 & 15.1 & 3.9 & 1 & 0 & 1 & 0 & 0 & 0.8 & 99.2 & 0 & 2 & 30.8 & 2.6 & 35.0 & 31.6 & 0 & 1 & 0 & 1 \\
\hline 20050512_f & 620.1 & 77.4 & 2.6 & 2.7 & 14.3 & 3.0 & 0 & 0 & 0 & 0 & 1 & 0.5 & 99.5 & 0 & 1 & 27.6 & 3.4 & 35.3 & 33.7 & 0 & 0 & 0 & 1 \\
\hline 20050621_f & 618.6 & 71.6 & 3.1 & 4.2 & 18.6 & 2.6 & 2 & 0 & 0 & 0 & 0 & 0.9 & 99.1 & 0 & 2 & 32.8 & 3.2 & 29.9 & 34.1 & 0 & 0 & 2 & 0 \\
\hline 20050428 f & 611.6 & 80.7 & 5.0 & 1.0 & 9.9 & 3.4 & 0 & 0 & 0 & 0 & 1 & 0.7 & 99.3 & 0 & 1 & 35.9 & 2.7 & 29.6 & 31.8 & 0 & 0 & 0 & 1 \\
\hline
\end{tabular}


Table 7. Categorical variables summarized by reach, including numbers of qualifying sturgeon relocations within 10 percent discharge and 7 days of the map date.-Continued

[SWH, shallow-water habitat; --, no data]

\begin{tabular}{|c|c|c|c|c|c|c|c|c|c|c|c|c|c|c|c|c|c|c|c|c|c|c|c|}
\hline \multirow[b]{3}{*}{$\begin{array}{c}\text { Map } \\
\text { identification }\end{array}$} & \multirow[b]{3}{*}{$\begin{array}{l}\text { Reach } \\
\text { center } \\
\text { river } \\
\text { mile }\end{array}$} & \multicolumn{10}{|c|}{ Substrate } & \multicolumn{4}{|c|}{ Shallow-water habitat } & \multicolumn{8}{|c|}{ Terrain classification } \\
\hline & & \multicolumn{5}{|c|}{ Percent of map area } & \multicolumn{5}{|c|}{ Number of relocations } & \multicolumn{2}{|c|}{$\begin{array}{l}\text { Percent of } \\
\text { map area }\end{array}$} & \multicolumn{2}{|c|}{$\begin{array}{l}\text { Number of } \\
\text { relocations }\end{array}$} & \multicolumn{4}{|c|}{ Percent of map area } & \multicolumn{4}{|c|}{ Number of relocations } \\
\hline & & $\begin{array}{l}\overline{\mathscr{d}} \\
\bar{E} \\
\bar{E} \\
\bar{E} \\
\bar{E} \\
\bar{心}\end{array}$ & 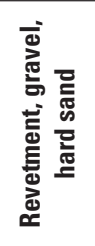 & 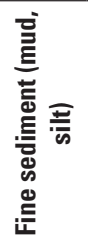 & 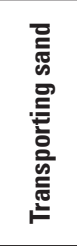 & 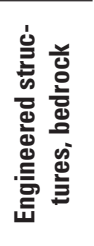 & 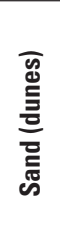 & 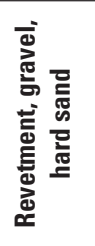 & 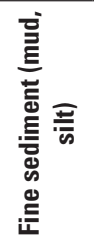 & 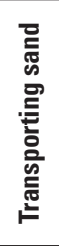 & 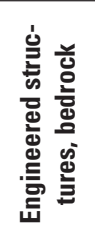 & 紊 & $\begin{array}{c}\frac{1}{3} \\
\frac{5}{2} \\
\frac{0}{2}\end{array}$ & 紊 & $\begin{array}{l}\frac{1}{3} \\
\text { c } \\
\frac{0}{2}\end{array}$ & $\frac{\pi}{\frac{\pi}{4}}$ & $\frac{\ddot{0}}{\operatorname{s}}$ & $\begin{array}{l}\overrightarrow{\mathrm{d}} \\
\stackrel{\mathrm{d}}{\mathrm{U}}\end{array}$ & 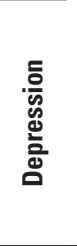 & $\frac{\pi}{\pi}$ & $\frac{\ddot{0}}{\dot{s}}$ & 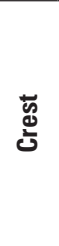 & 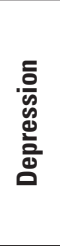 \\
\hline $20050506 \_f$ & 609.9 & 85.0 & 2.8 & 1.9 & 4.8 & 5.5 & 3 & 0 & 0 & 3 & 1 & 0.7 & 99.3 & 0 & 8 & 40.8 & 2.5 & 25.8 & 30.8 & 0 & 1 & 1 & 6 \\
\hline 20050605_f & 609.7 & 73.8 & 2.0 & 1.2 & 19.5 & 3.6 & 1 & 1 & 0 & 0 & 0 & 0.4 & 99.6 & 0 & 2 & 40.3 & 2.5 & 25.7 & 31.5 & 0 & 0 & 1 & 1 \\
\hline 20050508_f & 608.5 & 82.1 & 2.2 & 5.3 & 5.1 & 5.4 & 9 & 2 & 2 & 1 & 2 & 0.8 & 99.2 & 0 & 15 & 38.8 & 3.2 & 27.2 & 30.8 & 3 & 1 & 5 & 7 \\
\hline $20050429 \_\mathrm{f}$ & 608.2 & 80.1 & 4.3 & 2.4 & 7.6 & 5.6 & 1 & 0 & 0 & 0 & 0 & 0.1 & 99.9 & 0 & 1 & 43.7 & 3.1 & 25.1 & 28.1 & 0 & 0 & 0 & 1 \\
\hline 20050517_f & 606.8 & 80.9 & 2.3 & 1.7 & 10.0 & 5.1 & 1 & 0 & 0 & 0 & 0 & 0.6 & 99.4 & 0 & 1 & 38.3 & 3.2 & 27.9 & 30.6 & 0 & 0 & 1 & 0 \\
\hline 20050604_f & 604.0 & 81.2 & 3.1 & 2.1 & 10.8 & 2.8 & 1 & 0 & 1 & 0 & 0 & 1.4 & 98.6 & 0 & 2 & 30.9 & 3.0 & 32.6 & 33.6 & 0 & 1 & 0 & 1 \\
\hline 20050509_f & 602.4 & 84.5 & 2.4 & 2.4 & 6.9 & 3.7 & 1 & 0 & 0 & 0 & 1 & 1.3 & 98.7 & 0 & 2 & 39.7 & 2.7 & 24.4 & 33.2 & 0 & 0 & 1 & 1 \\
\hline 20050522_f & 601.2 & 80.4 & 4.0 & 2.6 & 9.3 & 3.7 & 1 & 0 & 0 & 0 & 0 & 0.1 & 99.9 & 0 & 1 & 42.2 & 3.4 & 23.9 & 30.5 & 0 & 0 & 0 & 1 \\
\hline 20050611_f & 593.7 & 79.5 & 2.1 & 0.7 & 12.6 & 5.1 & 1 & 0 & 0 & 0 & 0 & 1.2 & 98.8 & 0 & 1 & 22.3 & 2.8 & 32.8 & 42.1 & 0 & 0 & 0 & 1 \\
\hline 20050523_f & 588.6 & 77.0 & 5.4 & 2.0 & 11.3 & 4.3 & 1 & 0 & 0 & 0 & 0 & 0.0 & 100.0 & 0 & 1 & 38.2 & 3.6 & 27.6 & 30.6 & 0 & 0 & 1 & 0 \\
\hline 20060713_f & 583.8 & 78.4 & 4.0 & 2.8 & 11.1 & 3.6 & 3 & 1 & 0 & 0 & 2 & 0.3 & 99.7 & 0 & 6 & 53.5 & 2.7 & 21.8 & 22.0 & 0 & 1 & 3 & 2 \\
\hline 20050524_f & 565.5 & 76.4 & 3.5 & 2.8 & 14.7 & 2.6 & 1 & 0 & 0 & 0 & 0 & 0.1 & 99.9 & 0 & 1 & 34.3 & 2.8 & 30.6 & 32.3 & 0 & 0 & 1 & 0 \\
\hline 20050504_b & 362.7 & -- & -- & -- & -- & -- & -- & -- & -- & -- & -- & 3.0 & 97.0 & 0 & 1 & 19.5 & 2.6 & 39.6 & 38.2 & 0 & 0 & 1 & 0 \\
\hline 20050525 _b & 354.4 & -- & -- & -- & -- & -- & -- & -- & -- & -- & -- & 1.6 & 98.4 & 0 & 1 & 21.0 & 1.9 & 33.9 & 43.2 & 0 & 0 & 1 & 0 \\
\hline 20060620_b & 331.9 & 79.4 & 9.9 & 6.3 & 2.6 & 1.9 & 0 & 0 & 1 & 0 & 0 & 7.0 & 93.0 & 0 & 1 & 40.1 & 1.6 & 31.2 & 27.1 & 0 & 0 & 1 & 0 \\
\hline 20050429_b & 330.1 & -- & -- & -- & -- & -- & 0 & 0 & 0 & 0 & 0 & 3.0 & 97.0 & 0 & 1 & 34.7 & 1.8 & 32.1 & 31.4 & 0 & 0 & 1 & 0 \\
\hline 20060524_b & 326.8 & 89.1 & 5.0 & 2.7 & 0.7 & 2.6 & 4 & 0 & 0 & 0 & 0 & 3.9 & 96.1 & 0 & 4 & 34.1 & 1.9 & 33.8 & 30.1 & 0 & 1 & 2 & 1 \\
\hline 20050511_b & 325.2 & -- & -- & -- & -- & -- & -- & -- & -- & -- & -- & 7.7 & 92.3 & 0 & 1 & 29.4 & 2.0 & 33.9 & 34.7 & 0 & 0 & 1 & 0 \\
\hline 20050427_b & 315.1 & -- & -- & -- & -- & -- & -- & -- & -- & -- & -- & 0.8 & 99.2 & 0 & 1 & 40.2 & 2.1 & 27.3 & 30.4 & 0 & 0 & 0 & 1 \\
\hline 20050505_b & 311.6 & -- & -- & -- & -- & -- & -- & -- & -- & -- & -- & 2.4 & 97.6 & 0 & 1 & 30.4 & 1.9 & 34.6 & 33.1 & 0 & 0 & 0 & 1 \\
\hline $20050526 \_b$ & 291.8 & -- & -- & -- & -- & -- & -- & -- & -- & -- & -- & 2.3 & 97.7 & 0 & 1 & 23.2 & 1.8 & 39.3 & 35.7 & 1 & 0 & 0 & 0 \\
\hline 20060706_b & 289.4 & 80.5 & 8.3 & 8.5 & 0.5 & 2.3 & 2 & 0 & 0 & 0 & 0 & 3.4 & 96.6 & 0 & 2 & 31.5 & 2.4 & 33.9 & 32.2 & 0 & 0 & 2 & 0 \\
\hline 20060613_b_b & 281.4 & 73.7 & 14.7 & 2.6 & 5.2 & 3.9 & 3 & 0 & 0 & 0 & 0 & 7.5 & 92.5 & 0 & 3 & 24.1 & 2.2 & 37.4 & 36.4 & 1 & 0 & 2 & 0 \\
\hline 20060504_b & 280.6 & 83.7 & 4.0 & 0.6 & 8.2 & 3.5 & 1 & 0 & 0 & 0 & 0 & 0.1 & 99.9 & 0 & 1 & 40.3 & 2.1 & 27.6 & 30.1 & 0 & 0 & 0 & 1 \\
\hline 20060608_b & 279.7 & 81.7 & 5.9 & 2.6 & 6.3 & 3.5 & 0 & 0 & 1 & 0 & 0 & 2.4 & 97.6 & 0 & 1 & 33.4 & 1.8 & 33.6 & 31.2 & 0 & 0 & 1 & 0 \\
\hline 20050610_b & 275.8 & -- & -- & -- & -- & -- & -- & -- & -- & -- & -- & 0.0 & 100.0 & 0 & 1 & 25.0 & 1.8 & 34.6 & 38.5 & 0 & 0 & 1 & 0 \\
\hline 20060602_b & 247.6 & 81.5 & 6.4 & 6.0 & 3.1 & 3.0 & 0 & 1 & 0 & 0 & 0 & 5.7 & 94.3 & 0 & 1 & 33.3 & 2.1 & 32.2 & 32.4 & 0 & 0 & 1 & 0 \\
\hline 20050506_b & 230.5 & -- & -- & -- & -- & -- & -- & -- & -- & -- & -- & 3.0 & 97.0 & 0 & 1 & 29.2 & 1.5 & 32.4 & 36.9 & 0 & 0 & 1 & 0 \\
\hline 20050415_b & 219.2 & -- & -- & -- & -- & -- & -- & -- & -- & -- & -- & 0.7 & 99.3 & 0 & 1 & 29.8 & 1.7 & 33.7 & 34.8 & 0 & 0 & 1 & 0 \\
\hline 20060519_b & 218.8 & 66.0 & 7.9 & 4.1 & 21.2 & 0.9 & 1 & 0 & 0 & 0 & 0 & 5.7 & 94.3 & 1 & 0 & 32.3 & 2.2 & 30.7 & 34.8 & 0 & 0 & 1 & 0 \\
\hline
\end{tabular}


Table 7. Categorical variables summarized by reach, including numbers of qualifying sturgeon relocations within 10 percent discharge and 7 days of the map

date.-Continued

[SWH, shallow-water habitat; --, no data]

\begin{tabular}{|c|c|c|c|c|c|c|c|c|c|c|c|c|c|c|c|c|c|c|c|c|c|c|c|}
\hline \multirow[b]{3}{*}{$\begin{array}{c}\text { Map } \\
\text { identification }\end{array}$} & \multirow[b]{3}{*}{$\begin{array}{c}\text { Reach } \\
\text { center } \\
\text { river } \\
\text { mile }\end{array}$} & \multicolumn{10}{|c|}{ Substrate } & \multicolumn{4}{|c|}{ Shallow-water habitat } & \multicolumn{8}{|c|}{ Terrain classification } \\
\hline & & \multicolumn{5}{|c|}{ Percent of map area } & \multicolumn{5}{|c|}{ Number of relocations } & \multicolumn{2}{|c|}{$\begin{array}{l}\text { Percent of } \\
\text { map area }\end{array}$} & \multicolumn{2}{|c|}{$\begin{array}{l}\text { Number of } \\
\text { relocations }\end{array}$} & \multicolumn{4}{|c|}{ Percent of map area } & \multicolumn{4}{|c|}{ Number of relocations } \\
\hline & & 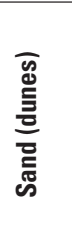 & 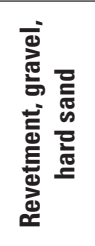 & 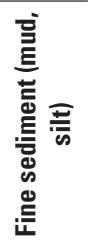 & 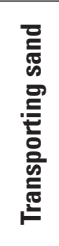 & 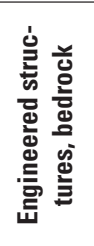 & 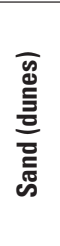 & 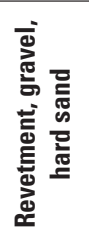 & 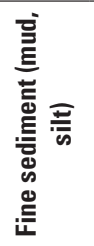 & 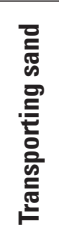 & 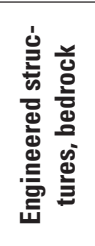 & 甹 & $\begin{array}{l}\frac{1}{3} \\
\frac{5}{2} \\
\frac{0}{2}\end{array}$ & 㞼 & $\begin{array}{l}\frac{1}{3} \\
\text { s } \\
\text { o }\end{array}$ & $\frac{\pi}{\frac{\pi}{4}}$ & 흥 & 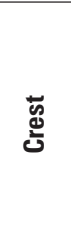 & 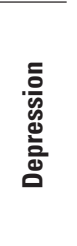 & $\frac{\pi}{\frac{\pi}{4}}$ & $\frac{\Xi}{\dot{0}}$ & 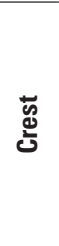 & 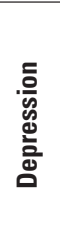 \\
\hline 20050627 b & 217.4 & -- & -- & -- & -- & -- & -- & -- & -- & -- & -- & 2.7 & 97.3 & 0 & 2 & 16.7 & 2.1 & 43.9 & 37.3 & 1 & 0 & 1 & 0 \\
\hline $20050428 \_b$ & 203.3 & -- & -- & -- & -- & -- & -- & -- & -- & -- & -- & 1.0 & 99.0 & 0 & 1 & 40.0 & 1.4 & 28.5 & 30.1 & 0 & 0 & 0 & 1 \\
\hline 20050407_b & 201.6 & -- & -- & -- & -- & -- & -- & -- & -- & -- & -- & 4.6 & 95.4 & 0 & 2 & 39.7 & 1.6 & 29.9 & 28.8 & 0 & 1 & 1 & 0 \\
\hline $20050408 \_f$ & 199.7 & 82.7 & 7.0 & 6.6 & 2.2 & 1.5 & 1 & 0 & 0 & 0 & 1 & 0.8 & 99.2 & 0 & 2 & 57.5 & 0.9 & 23.9 & 17.8 & 1 & 0 & 1 & 0 \\
\hline 20060707_b & 196.0 & 76.9 & 11.8 & 8.4 & 0.3 & 2.5 & 2 & 0 & 0 & 0 & 0 & 8.2 & 91.8 & 0 & 2 & 32.9 & 1.6 & 33.1 & 32.4 & 2 & 0 & 0 & 0 \\
\hline 20050527_b & 186.8 & -- & -- & -- & -- & -- & -- & -- & -- & -- & -- & 1.5 & 98.5 & 0 & 1 & 26.7 & 2.0 & 35.3 & 36.0 & 0 & 1 & 0 & 0 \\
\hline 20050412_b & 178.0 & -- & -- & -- & -- & -- & -- & -- & -- & -- & -- & 3.8 & 96.2 & 1 & 0 & 24.8 & 1.3 & 37.9 & 36.0 & 0 & 0 & 1 & 0 \\
\hline 20060510_b & 177.4 & 82.7 & 9.2 & 2.7 & 3.3 & 2.2 & 1 & 0 & 0 & 0 & 0 & 7.4 & 92.6 & 0 & 1 & 27.1 & 1.7 & 35.4 & 35.8 & 0 & 0 & 0 & 1 \\
\hline 20050601_b & 173.5 & -- & -- & -- & -- & -- & -- & -- & -- & -- & -- & 2.9 & 97.1 & 0 & 1 & 35.5 & 1.8 & 32.6 & 30.2 & 0 & 0 & 1 & 0 \\
\hline 20050701_b & 168.0 & -- & -- & -- & -- & -- & -- & -- & -- & -- & -- & 1.0 & 99.0 & 0 & 1 & 35.1 & 1.7 & 32.4 & 30.7 & 0 & 0 & 0 & 1 \\
\hline 20060621_b & 165.5 & 79.4 & 13.0 & 4.9 & 1.5 & 1.2 & 1 & 0 & 0 & 0 & 0 & 7.5 & 92.5 & 0 & 1 & 35.8 & 1.9 & 31.6 & 30.8 & 0 & 0 & 1 & 0 \\
\hline 20050510_b & 160.5 & -- & -- & -- & -- & -- & -- & -- & -- & -- & -- & 3.0 & 97.0 & 0 & 1 & 26.8 & 1.9 & 35.6 & 35.6 & 0 & 0 & 1 & 0 \\
\hline 20050810_b & 146.5 & -- & -- & -- & -- & -- & -- & -- & -- & -- & -- & 5.3 & 94.7 & 0 & 1 & 42.5 & 1.1 & 30.5 & 25.8 & 0 & 0 & 0 & 1 \\
\hline 20050809_b & 142.0 & -- & -- & -- & -- & -- & -- & -- & -- & -- & -- & 2.3 & 97.7 & 0 & 1 & 28.9 & 2.4 & 35.3 & 33.4 & 0 & 0 & 1 & 0 \\
\hline 20050602_b & 140.8 & -- & -- & -- & -- & -- & -- & -- & -- & -- & -- & 7.4 & 92.6 & 0 & 1 & 22.9 & 2.5 & 34.8 & 39.8 & 0 & 0 & 1 & 0 \\
\hline 20050419_b & 130.6 & -- & -- & -- & -- & -- & -- & -- & -- & -- & -- & 1.9 & 98.1 & 0 & 3 & 40.3 & 1.3 & 30.4 & 28.0 & 2 & 0 & 0 & 1 \\
\hline 20060509_b & 127.6 & 82.1 & 5.9 & 3.3 & 6.5 & 2.3 & 1 & 0 & 0 & 0 & 0 & 0.5 & 99.5 & 0 & 1 & 36.7 & 1.6 & 30.3 & 31.4 & 1 & 0 & 0 & 0 \\
\hline 20050426_b & 127.3 & -- & -- & -- & -- & -- & -- & -- & -- & -- & -- & 0.2 & 99.8 & 0 & 1 & 23.1 & 1.5 & 37.7 & 37.7 & 0 & 0 & 0 & 1 \\
\hline 20060630_b & 119.6 & 79.3 & 10.7 & 7.8 & 0.7 & 1.5 & 2 & 0 & 0 & 0 & 0 & 4.7 & 95.3 & 0 & 2 & 39.7 & 1.8 & 29.3 & 29.3 & 1 & 0 & 1 & 0 \\
\hline 20050503_b & 118.5 & -- & -- & -- & -- & -- & -- & -- & -- & -- & -- & 1.3 & 98.7 & 0 & 1 & 38.1 & 1.3 & 33.6 & 27.0 & 0 & 0 & 0 & 1 \\
\hline 20050706_b & 118.2 & -- & -- & -- & -- & -- & -- & -- & -- & -- & -- & 0.4 & 99.6 & 0 & 1 & 31.1 & 1.3 & 36.9 & 30.7 & 1 & 0 & 0 & 0 \\
\hline 20050707_b & 75.8 & -- & -- & -- & -- & -- & -- & -- & -- & -- & -- & 3.0 & 97.0 & 0 & 1 & 27.6 & 1.5 & 36.4 & 34.5 & 0 & 0 & 1 & 0 \\
\hline 20050708 b & 27.3 & -- & -- & -- & -- & -- & -- & -- & -- & -- & -- & 0.1 & 99.9 & 0 & 1 & 48.4 & 0.9 & 25.9 & 24.7 & 0 & 0 & 1 & 0 \\
\hline
\end{tabular}


Table 8. Summary of categorical data by river section, including percent of map area, percent of relocations, and Ivlev's selectivity coefficient.

[SWH, shallow-water habitat]

\begin{tabular}{|c|c|c|c|c|c|c|c|c|c|c|c|}
\hline \multirow[b]{2}{*}{ River section } & \multicolumn{5}{|c|}{ Generalized substrate } & \multicolumn{2}{|c|}{ Shallow-water habitat } & \multicolumn{4}{|c|}{ Terrain classification } \\
\hline & $\begin{array}{c}\text { Sand } \\
\text { (dunes) }\end{array}$ & $\begin{array}{l}\text { Revetment, } \\
\text { gravel, hard } \\
\text { sand }\end{array}$ & $\begin{array}{c}\text { Fine } \\
\text { sediment } \\
\text { (mud, silt) }\end{array}$ & $\begin{array}{l}\text { Transporting } \\
\text { sand }\end{array}$ & $\begin{array}{l}\text { Engineered } \\
\text { structures } \\
\text { (rock) }\end{array}$ & SWH & Not SWH & Flat & Slope & Crest & Depression \\
\hline \multicolumn{12}{|c|}{ Percent of map area } \\
\hline Minimally Engineered & 82.1 & 7.5 & 2.8 & 5.3 & 2.3 & 11.1 & 88.9 & 44.0 & 1.7 & 29.8 & 24.5 \\
\hline Upstream Channelized & 79.6 & 4.2 & 1.6 & 10.4 & 4.1 & 1.0 & 99.0 & 37.0 & 2.8 & 29.6 & 30.6 \\
\hline Downstream Channelized & 80.0 & 8.5 & 5.0 & 4.3 & 2.2 & 3.1 & 96.9 & 32.4 & 1.7 & 33.3 & 32.6 \\
\hline All & 80.0 & 5.8 & 2.7 & 8.1 & 3.4 & 3.5 & 96.5 & 35.7 & 2.1 & 31.4 & 30.7 \\
\hline \multicolumn{12}{|c|}{ Percent of relocations } \\
\hline Minimally Engineered & 72.8 & 14.1 & 3.3 & 5.4 & 4.3 & 3.8 & 96.2 & 29.3 & 3.8 & 14.3 & 52.6 \\
\hline Upstream Channelized & 66.1 & 5.8 & 4.1 & 6.4 & 17.5 & 2.2 & 97.8 & 21.4 & 10.7 & 33.7 & 34.2 \\
\hline Downstream Channelized & 82.6 & 4.3 & 8.7 & 0.0 & 4.3 & 3.7 & 96.3 & 20.4 & 5.6 & 53.7 & 20.4 \\
\hline All & 69.6 & 8.4 & 4.2 & 5.6 & 12.2 & 3.0 & 97.0 & 24.1 & 7.5 & 29.7 & 38.8 \\
\hline \multicolumn{12}{|c|}{ Ivlev's selectivity coefficient } \\
\hline Minimally Engineered & -0.06 & 0.31 & 0.07 & 0.01 & 0.31 & -0.49 & 0.04 & -0.20 & 0.38 & -0.35 & 0.36 \\
\hline Upstream Channelized & -0.09 & 0.17 & 0.43 & -0.24 & 0.62 & 0.38 & -0.01 & -0.27 & 0.58 & 0.06 & 0.06 \\
\hline Downstream Channelized & 0.02 & -0.32 & 0.27 & -1.00 & 0.32 & 0.09 & -0.00 & -0.23 & 0.52 & 0.23 & -0.23 \\
\hline All & -0.07 & 0.18 & 0.22 & -0.18 & 0.57 & -0.07 & 0.00 & -0.20 & 0.55 & -0.03 & 0.12 \\
\hline
\end{tabular}


Specifically, the reclassification was as follows: velocity gradient: $80-100$ percentile $=1$ depth slope: $80-100$ percentile $=1$

Froude number: $0-20$ percentile $=1$

After reclassifying each individual variable, we combined the maps by adding them together. In the resulting maps, each grid cell has a value from 0 to 3 , representing the number of variables that fall within the ranges specified above. Groups of grid cells form selected patches.

The resulting maps show different patterns in each major section of river. Example reaches that illustrate some of these patterns are shown in figure 22. In the Minimally Engineered section, the areas of predicted selection form a relatively complex mosaic with abundant connections among selected patches, often forming a series of longitudinal pathways through the reach. In the Upstream Channelized section, the patches of predicted selection are strongly associated with the edges of the channel, and the values are often coincident with each other. In the Downstream Channelized section, predicted selected patches tend to be at the channel margins, especially in dike fields.

To assess whether these patches predict sturgeon relocations, we summarized the number of sturgeon relocations within each patch in each map, limiting the analysis to sturgeon relocations from the same year as the map. Findings from this simple analysis support the idea that sturgeon are indeed using certain patches more than others in a predictable way. Of 2,013 relocations in total, about 18 percent of these fell within about 4 percent of the map area where all three variables were in the predicted selection ranges; about 63 percent of the relocations fell within about 35 percent of the area represented by at least one variable in the predicted selection ranges (table 9).

\section{Discussion}

Describing habitats selected by adult Scaphirhynchus sturgeon in the Lower Missouri River is just one step in the process of developing a broader understanding of how sturgeon perceive habitat, the relative value of different habitats to sturgeon, and what constitutes quality sturgeon habitat. Ultimately, the improved understanding can contribute to determining how and to what extent habitat alteration contributes to the decline of sturgeon species in the Lower Missouri River. We observed and described relations between positions of sturgeon and environmental characteristics. Sturgeon can go almost anywhere within the channel, but they show a tendency to select some habitats while avoiding others. These relations are based on observations of sturgeon habitat selection in an altered system, so we caution against extending these results to infer sturgeon habitat needs or preferences. That said, the relatively consistent patterns of selection for high depth slope, high velocity gradient, and low Froude number in geomorphically diverse river sections suggests that some sturgeon responses to habitat may transcend availability. In contrast, selection for depth appears more complex. The difference in depth selection may indicate interaction with other factors like turbidity, which could affect a sturgeon's need to seek greater depths for cover or to seek prey.

The two primary methods for the analysis of habitat selection in this report yielded results that were largely complementary (figs. 20,21). The decile approach most directly addressed the concept of habitat selection by comparing variable values at sturgeon relocations to the range of available habitat that was available strictly within the reach where each sturgeon was found. In contrast, Ivlev's selectivity coefficients yielded results in terms of the actual values of the habitat variables that sturgeon tend to select or avoid. Such values may be more readily useful from an engineering standpoint. The similarity of the results obtained from both methods is an indicator of robustness. We feel that the robustness also is a byproduct of ensuring that Ivlev's selectivity coefficients were computed within geomorphically similar river sections under non-extreme flow conditions.

The best descriptors of selected habitat that we have explored are depth slope, velocity gradient, and Froude number. Quantification of these variables can be used in exploratory modeling of habitat, and, therefore, in the prediction of how channel reconfigurations and flow changes could alter the distribution of identified habitat. Hydrodynamic modeling can help to better define how patches defined by these variables change as a function of discharge. Initial assessments suggest that selected patches may show some persistence across discharge; this may be because of the interrelation of variables in question: depth and velocity tend to be correlated, as do depth slope and velocity gradient to a lesser degree. Because depth slope is effectively independent of discharge if the bed is stable, persistence of major patterns of depth slope and velocity gradient across moderate changes in discharge is a reasonable expectation. For habitat assessments that have taken the approach of defining patches based on specified ranges of depth and velocity (for example, Jacobson and others, 2009b), it may be the edges, not the patches themselves, that are important. Analysis of habitat patch and edge structure should also address longitudinal and lateral connectivity, especially for habitats which are for migrating, reproductive adults.

The habitat template varies by section of the Lower Missouri River. Developing an understanding of habitat selection and distributions may eventually provide some guidance on what types of habitats may need to be increased in specific parts of the river. Selected habitats and patch structure are most complex and interconnected in the Minimally Engineered section, which may be closest to a reference condition in a geomorphic sense. The fragmented patch structure of the Upstream Channelized section indicates that it could be relatively unsupportive of adult sturgeon. Conversely, recovering dynamism of habitats has been suggested as a restoration goal for the Lower Missouri River (National Research Council, 2002). The Upstream Channelized section has active in-chan- 


\section{$\boldsymbol{A}$}
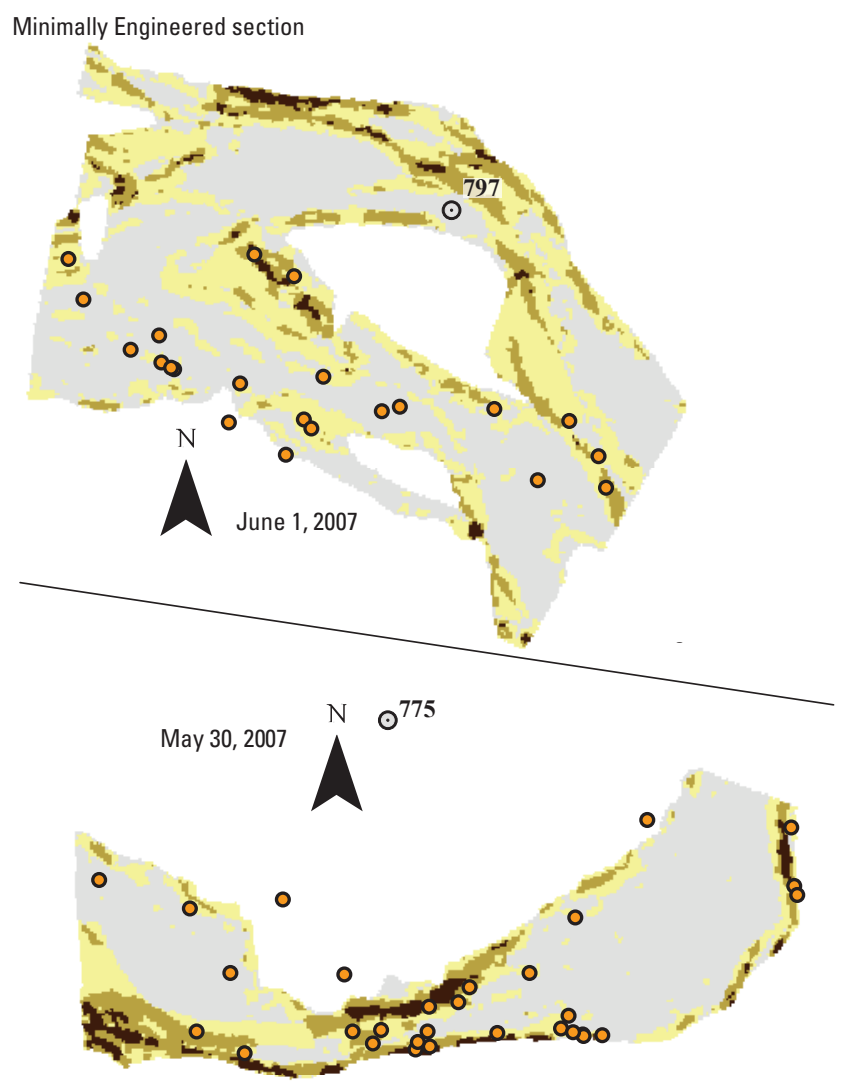

EXPLANATION

Number of the following conditions that are satisified: Depth slope between the 80th percentile and maximum Velocity gradient between the 80th percentile and maximum Froude number between the minimum and 20th percentile

$\square$ variables

$\square$ variable

$\square 2$ variables

(2)

3 variables

Sturgeon relocations from the year of mapping

- 2005 sturgeon relocation

- 2006 sturgeon relocation

- 2007 sturgeon relocation

$\odot \quad$ River-mile marker-

Number is distance upstream from the junction with the

Mississippi River, in miles

Universal Transverse Mercator projection Zone 14

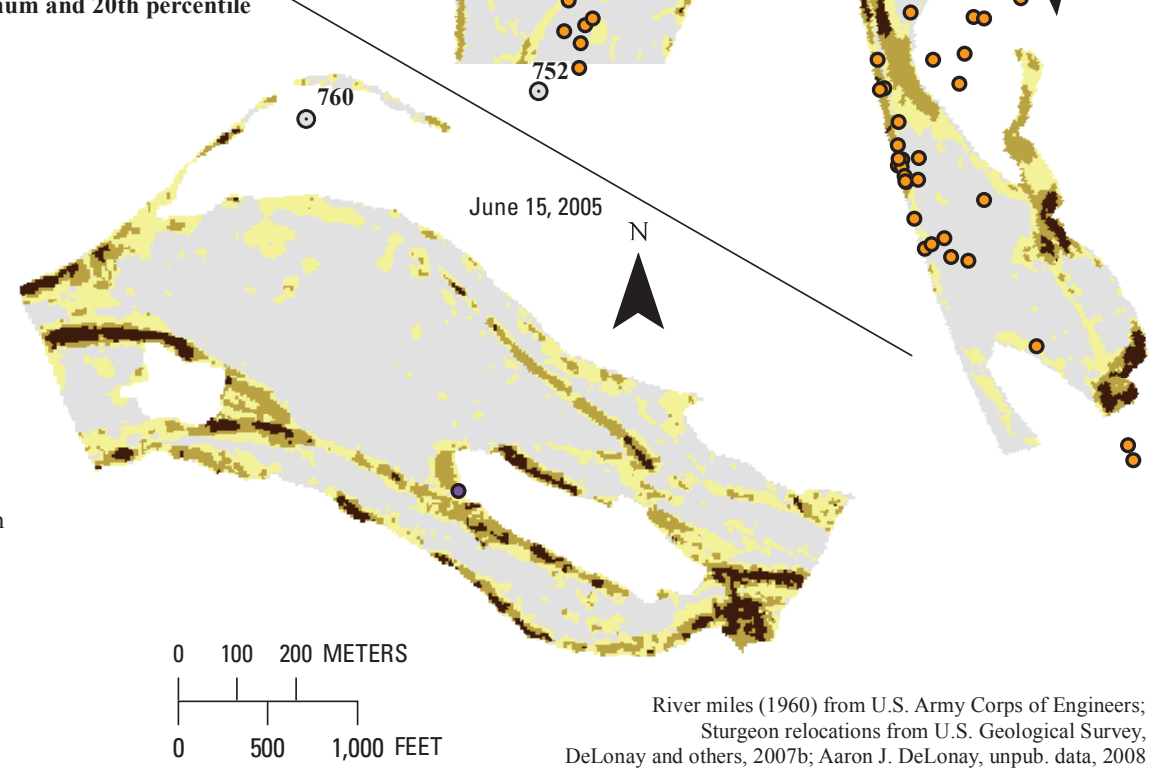

Figure 22. Example maps from each river section showing the distribution of areas with high depth slope, high velocity gradient, and/or low Froude number. Sturgeon relocations from the year of mapping are also shown. Each grid cell represents the number of the following criteria that were met: depth slope greater than the 80th percentile in the reach, velocity gradient greater than the 80th percentile in the reach, and Froude number less than the 20th percentile in the reach. 
B
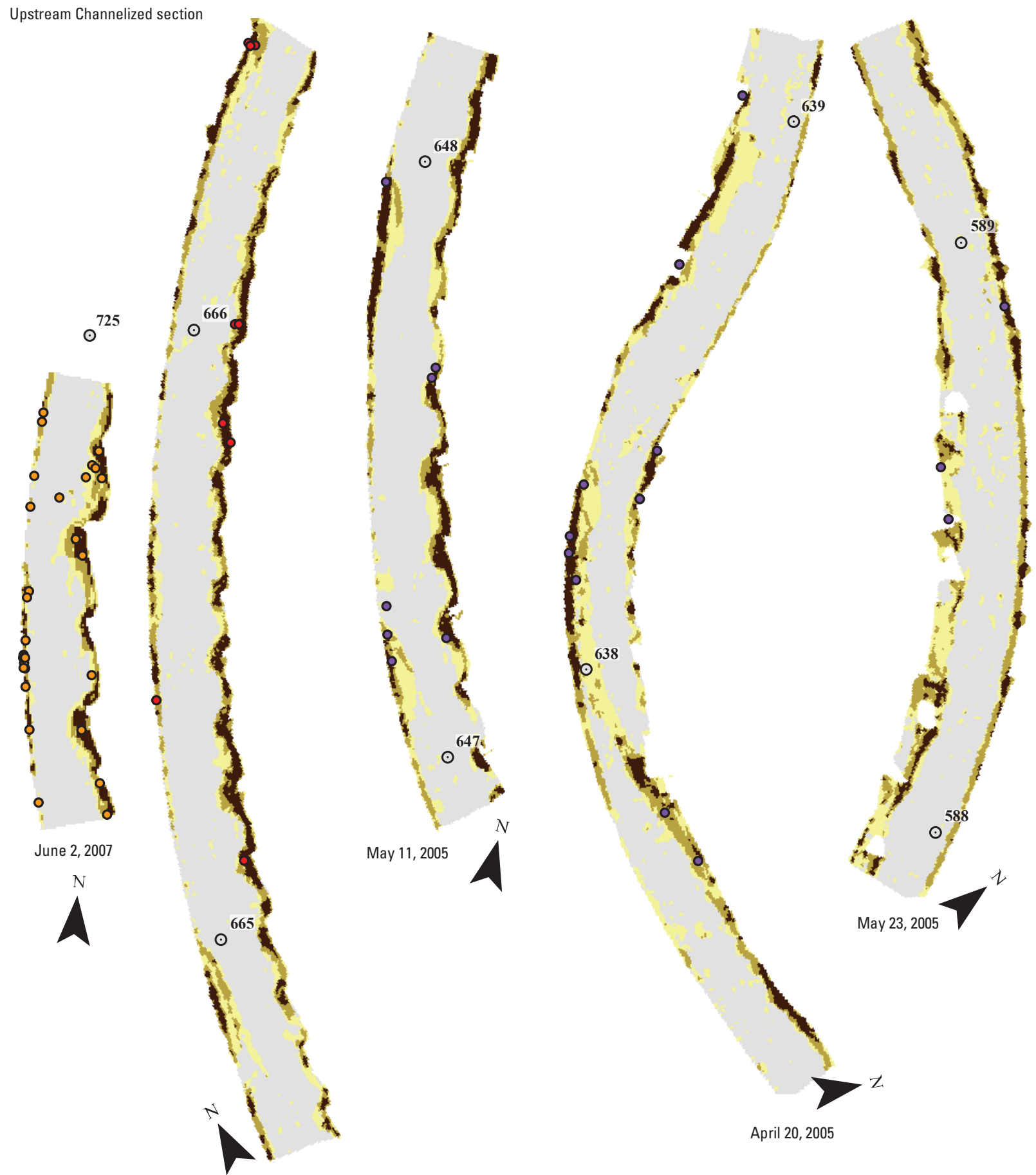

April 20, 2005

June 6, 2006

Universal Transverse Mercator projection Zone 14

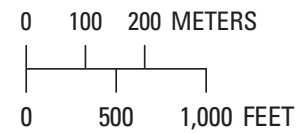

River miles (1960) from U.S. Army Corps of Engineers; Sturgeon relocations from U.S. Geological Survey, DeLonay and others, 2007b; Aaron J. DeLonay, unpub. data, 2008

Figure 22. Example maps from each river section showing the distribution of areas with high depth slope, high velocity gradient, and/or low Froude number. Sturgeon relocations from the year of mapping are also shown. Each grid cell represents the number of the following criteria that were met: depth slope greater than the 80th percentile in the reach, velocity gradient greater than the 80th percentile in the reach, and Froude number less than the 20th percentile in the reach.-Continued 


\section{C}

Downstream Channelized section
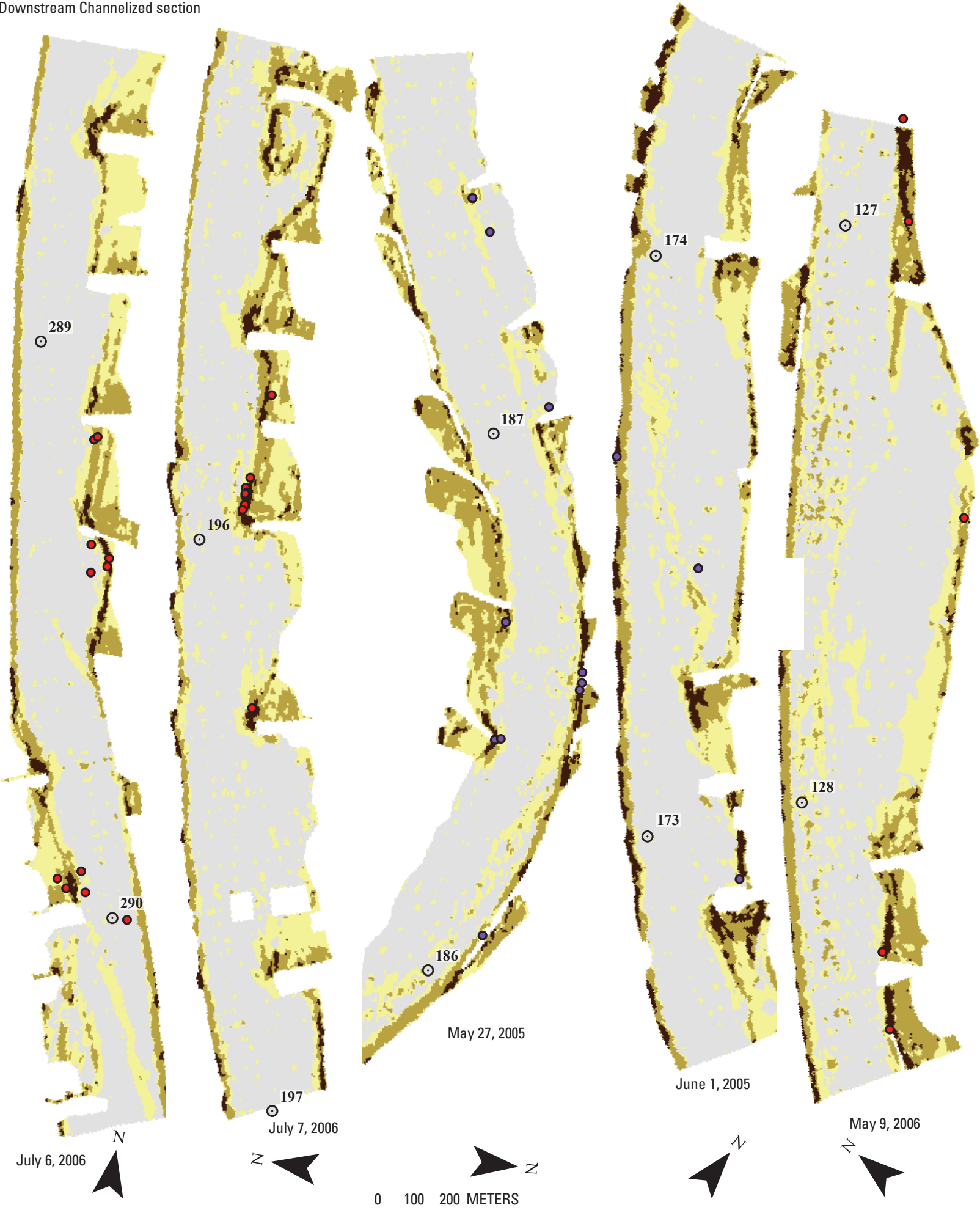

Universal Transverse Mercator projection

Zone 15

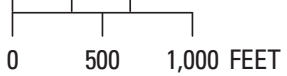

River miles (1960) from U.S. Army Corps of Engineers; Sturgeon relocations from U.S. Geological Survey,

DeLonay and others, 2007b; Aaron J. DeLonay, unpub. data, 2008

Figure 22. Example maps from each river section showing the distribution of areas with high depth slope, high velocity gradient, and/or low Froude number. Sturgeon relocations from the year of mapping are also shown. Each grid cell represents the number of the following criteria that were met: depth slope greater than the 80th percentile in the reach, velocity gradient greater than the 80th percentile in the reach, and Froude number less than the 20th percentile in the reach.-Continued 
Table 9. Comparison of distribution of shovelnose sturgeon relocations to distribution of high depth slope, high velocity gradient, and/ or low Froude habitats.

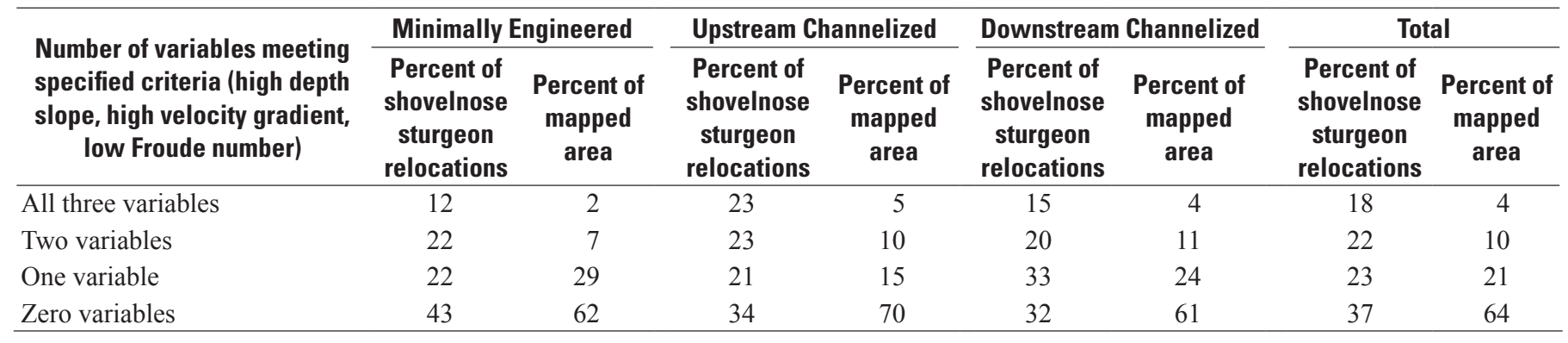

nel dynamics that may have important ecological functions (Elliott and others, 2009).

This study addresses a specific cross-section of time, geography, discharge conditions, and portion of the sturgeon life cycle with a focus on reproductive female shovelnose sturgeon. Use of certain habitats by sturgeon in the modern river does not necessarily mean that those are the habitats that the sturgeon would have used under pre-alteration channel and flow conditions, nor does selection of those habitats in the modern river necessarily mean that individual sturgeon are or will be successful reproductively or otherwise. More work is needed to identify factors limiting reproduction and survival.

At the outset of this project (2005), the understanding of Scaphirhynchus sturgeon movement and habitat use in the Missouri River was rudimentary, and little information existed to develop testable hypotheses regarding how sturgeon interact with and select habitat. The 2005 through 2007 data thus provided basic observations suitable for exploratory data analysis as presented in this report. We offer a series of ideas for future data collection and analysis. The order of this list is not intended to be a prioritization. Overall, the list is roughly ordered so that it begins with ideas that are easier to achieve within the existing research framework and ends with suggestions that require substantially more data and associated investment of resources.

- Develop a set of informed, mathematically based, working hypotheses regarding habitat selection to be tested with an information theoretic approach using new data (Burnham and Anderson, 2002). Hypotheses should be based on results from the exploratory analysis combined with expert opinion.

- Assess migration and energy expenditure:

- Develop a better understanding of migratory pathways. Document migratory paths in greater detail with high frequency telemetry relocations within a reach while mapping habitat simultaneously. Assess the extent to which migratory paths coincide with hypothesized selection zones.

- Assess energy expenditure through migratory pathways through reaches with distinct geomorphic char- acteristics (for example, Standen and others, 2002) and whether this might affect spawning success. Consider availability and use of low-energy expenditure pathways, and how these vary by river section. Physiological assessments of stress or analysis of rates of migration through different river sections may also yield insight to this question.

- Assess use of natural and constructed side-channel chutes for migration (as observed in 2008, Aaron J. DeLonay, unpub. data, 2008) and the habitat conditions in chutes in comparison to the main channel.

- Document habitat in greater detail, such that available habitat is mapped at the scale of sturgeon (with grid cell resolution of 1 meter or less). For example, develop an understanding of how sturgeon interact with bedforms and the extent to which they move up and down in the water column. Multibeam bathymetric mapping and hydroacoustic imaging technologies could be deployed to address these questions.

- Further assess relations between discharge, channel morphology, and habitat:

- Consider habitat availability as a function of discharge in a hydrodynamic model context (Jacobson and others, 2009b), specifically considering the occurrence of ranges of variables that sturgeon show a tendency to select. Expand spatial understanding of habitats in terms of patch structure and juxtaposition. Consider a historic context in a semiquantitative way by comparing a hydrodynamic model for modern conditions with one for pre-engineered conditions (for example, Jacobson and Galat, 2006). For example, how does availability of low energy habitat at high flow in a pre-engineered context compare to that in the modern channel?

- Assess the effect of discharge on habitat selection. Document where sturgeon go at extreme discharges, and attempt to make maps in close time proximity to relocations if discharge conditions are changing rapidly. At high discharge, do sturgeon continue to 
migrate? Do they seek refuge? How do they respond to high rates of sediment transport? How do available conditions in the modern channel compare to conditions that would have been available at similar discharges in a natural channel? Is sturgeon habitat limited or are patch dynamics significantly altered at low flow conditions? How does ice alter habitat during low winter discharge?

- Assess sturgeon use and selection of habitats associated with engineered channel modifications.

- Consider whether shovelnose and pallid sturgeon select habitat in the same way, and whether habitat use and availability explains patterns of distribution and rarity.

- Expand data collection and analysis of habitat use and selection to include full reproductive cycles extending over multiple years. This includes:

- Continuation of work to document and verify specific spawning habitat patches; this remains a high priority for understanding spawning habitat and spawning success (Bergman and others, 2008).

- Comparison of habitat use based on behavior and context of movement history (semistationary, migrating upstream, migrating downstream). Does habitat use vary prior to and after spawning?

- Study of younger life stages. Migrating adults may not be a bottleneck in reproductive success (Wildhaber and others, 2007a), so habitat use by larval and juvenile sturgeon should be considered, too.

- Consideration of seasonal use of habitat. For example, in a habitat context, where do sturgeon overwinter?

- Expand understanding of habitat function. For example, are foraging habitats different from migratory habitats? When and where do sturgeon feed?

- Expand from a species-centric focus to an ecosystemlevel understanding by addressing habitats of species with which sturgeon interact. What habitats are important to prey species of sturgeon? Are pallid sturgeon and shovelnose sturgeon competitors? How does habitat affect invasive species (such as Asian carp, Kolar and others, 2007), and to what extent do invasive species affect sturgeon?

\section{Summary}

This exploratory analysis provided information about the longitudinal geomorphology and hydraulics of the Lower Missouri River, the distribution of sturgeon within the range of available habitat, and the distribution of habitat that appears to be selected by sturgeon.

The habitat structure of the river is strongly related to the engineering framework. The Minimally Engineered section, from Gavins Point Dam to Sioux City, Iowa, has the least engineered channel with typical reaches exhibiting shallow depths, high widths, and relatively low mean velocities. In the Upstream Channelized section of the river, from Sioux City to beyond the junction with the Platte River, the channel typically is narrow, deep, and relatively fast. In the Downstream Channelized section of the river, downstream from Kansas City, the channel widens and has more complexity; the navigation channel is deep and fast, but more diversity exists along the channel margins. The longitudinal geomorphic patterns indicate that choices of habitat available to sturgeon are different depending on location in the river.

An assessment of the environmental characteristics at sturgeon relocations compared to each surrounding reach suggests that sturgeon were found in nearly the full range of available habitat. However, sturgeon do show a tendency to select some habitats while avoiding others. The patterns of depth availability and selection by sturgeon vary considerably among river sections. In contrast, patterns of selection for other variables show consistency among river sections. In particular, during the spring and summer months of this study, reproductive female shovelnose sturgeon tended to select areas of high velocity gradient, high depth slope, and/or low Froude number.

Composite maps illustrate the spatial patterns of habitats characterized by high velocity gradient, high depth slope, and/ or low Froude number. Sturgeon relocations are disproportionately located in areas with these characteristics. Furthermore, the spatial patterns of these selected habitats show distinct difference among the sections of the Lower Missouri River. Because the patterns described in this report represent habitat use in the context of the available habitat in a highly altered river system, selection may not necessarily indicate preferred habitats or habitats sufficient for reproduction and survival of sturgeon species.

\section{References Cited}

Alexander, R.B., Smith, R.A., Schwarz, G.E., Boyer, E.W., Nolan, J.V., and Brakebill, J.W., 2008, Differences in phosphorus and nitrogen delivery to the Gulf of Mexico from the Mississippi River Basin: Environmental Science \& Technology, v. 42 , no. 3, p. 822-830.

Auer, N.A., 1996, Importance of habitat and migration to sturgeons with emphasis on lake sturgeon: Canadian Journal of Fisheries and Aquatic Sciences, v. 53 (Suppl. 1), p. $152-160$. 
Bemis, W.E., and Kynard, B., 1997, Sturgeon rivers-An introduction to acipenseriform biogeography and life history: Environmental Biology of Fishes, v. 48, p. 167-183.

Benda, L., Poff, N.L., Miller, D., Dunne, T., Reeves, G., Pess, G., and Pollock, M., 2004, The network dynamics hypothesis-How channel networks structure riverine habitats: BioScience, v. 54, p. 413-427.

Bergman, H.L., Boelter, A.M., Parady, K., Fleming, C., Keevin, T., Latka, D.C., Korschgen, C.E., Galat, D.L., Hill, T., Jordan, G., Krentz, S., Nelson-Stastny, W., Olson, M., Mestl, G.E., Rouse, K., and Berkley, J., 2008, Research needs and management strategies for pallid sturgeon recovery-Final report to the U.S. Army Corps of Engineers: Laramie, Wyo., William D. Ruckelshaus Institute of Environment and Natural Resources, University of Wyoming, $102 \mathrm{p}$.

Bramblett, R.G., and White, R.G., 2001, Habitat use and movements of pallid and shovelnose sturgeon in the Yellowstone and Missouri Rivers in Montana and North Dakota: Transactions of the American Fisheries Society, v. 130, p. $1,006-1,025$.

Burnham, K.P., and Anderson, D.R., 2002, Model selection and multimodel inference-A practical information-theoretic approach (2nd ed.): New York, Springer, 488 p.

Cech, J.J., Jr., and Doroshov, S.I., 2004, Environmental requirements, preferences, and tolerance limits of North American sturgeons, in LeBreton, G.T.O., Beamish, F.W.H., and McKinley, R.S., eds., Sturgeons and paddlefish of North America: Dordrecht, the Netherlands, Kluwer Academic Publishers, p. 73-86.

Chittenden, H.M., 1903, History of early steamboat navigation on the Missouri River-Life and adventures of Joseph La Barge: New York, Harper, v. 1, accessed on May 20, 2009, at http://books.google.com

Crowder, D.W., and Diplas, P., 2000, Evaluating spatially explicit metrics of stream energy gradients using hydrodynamic model simulations: Canadian Journal of Fisheries and Aquatic Sciences, v. 57, p. 1,497-1,507.

Crowder, D.W., and Diplas, P., 2006, Applying spatial hydraulic principles to quantify stream habitat: River Research and Applications, v. 22, p. 79-89.

DeLonay, A.J., Papoulias, D.M., Wildhaber, M.L., Annis, M.L., Bryan, J.L., Griffith, S.A., Holan, S.H., and Tillitt, D.E., 2007a, Use of behavioral and physiological indicators to evaluate Scaphirhynchus sturgeon spawning success: Journal of Applied Ichthyology, v. 23, p. 428-435.
DeLonay, A.J., Papoulias, D.M., Wildhaber, M.L., Mestl, G.E., Everitt, D.W., and Chojnacki, K.A., 2007b, Movement, habitat use, and reproductive behavior of shovelnose sturgeon and pallid sturgeon in the Lower Missouri River, in Korschgen, C.E., ed., Factors affecting the reproduction, recruitment, habitat, and population dynamics of pallid sturgeon and shovelnose sturgeon in the Missouri River: U.S. Geological Survey Open-File Report 2007-1262, p. $23-102$.

Dryer, M.P., and Sandvol, A.J., 1993, Recovery plan for the pallid sturgeon (Scaphirhynchus albus): U.S. Fish and Wildlife Service-Region 6, 55 p., accessed on January 21, 2009, at http://ecos.fws.gov/docs/recovery plans/1993/931107.pdf

Echols, K.R., Brumbaugh, W.G., Orazio, C.E., May, T.W., Poulton, B.C., and Peterman, P.H., 2008, Distribution of pesticides, PAHs, PCBs, and bioavailable metals in depositional sediments of the Lower Missouri River, USA: Archives of Environmental Contamination and Toxicology, v. 55 , no. 2 , p. $161-172$.

Elliott, C.M., and Jacobson, R.B., 2006, Geomorphic classification and assessment of channel dynamics in the Missouri National Recreational River, South Dakota and Nebraska: U.S. Geological Survey Scientific Investigations Report 2006-5313, $66 \mathrm{p}$.

Elliott, C.M., Reuter, J.M., and Jacobson, R.B., 2009, Channel morphodynamics in four reaches of the Lower Missouri River, 2006-07: U.S. Geological Survey Scientific Investigations Report 2009-5074, 258 p.

Ferrell, J., 1996, Soundings-100 years of the Missouri River navigation project: Omaha, Nebr., U.S. Army Corps of Engineers, $171 \mathrm{p}$.

Frissell, C.A., Liss, W.J., Warren, C.E., and Hurley, M.D., 1986, A hierarchical framework for stream habitat classification - Viewing streams in a watershed context: Environmental Management, v. 10, no. 2, p. 199-214.

Funk, J.L., and Robinson, J.W., 1974, Changes in the channel of the lower Missouri River and effects on fish and wildlife: Jefferson City, Mo., Missouri Department of Conservation, $52 \mathrm{p}$.

Galat, D.L., Berry, C.R., Gardner, W.M., Hendrickson, J.C., Mestl, G.E., Power, G.J., Stone, C., and Winston, M.R., 2005a, Spatiotemporal patterns and changes in Missouri River fishes: American Fisheries Society Symposium, v. 45, p. 249-291.

Galat, D.L., Berry, C.R., Jr., Peters, E.J., and White, R.G., 2005b, Missouri River basin, in Benke, A.C., and Cushing, C.E., eds., Rivers of North America: Oxford, Elsevier Academic Press, p. 427-480. 
Galat, D.L., and Lipkin, R., 2000, Restoring ecological integrity of great rivers - Historical hydrographs aid in defining reference conditions for the Missouri River: Hydrobiologia, v. $422 / 423$, p. $29-48$.

Gordon, N.D., McMahon, T.A., and Finlayson, B.L., 1992, Stream hydrology — An introduction for ecologists: Chichester, England, John Wiley and Sons, 526 p.

Hall, L.S., Krausman, P.R., and Morrison, M.L., 1997, The habitat concept and a plea for standard terminology: Wildlife Society Bulletin, v. 25, p. 173-182.

Hesse, L.W., 1987, Taming the wild Missouri River-What has it cost?: Fisheries, v. 12, no. 2, p. 2-9.

Hesse, L.W., Schmulbach, J.C., Carr, J.M., Keenlyne, K.D., Unkenholz, D.G., Robinson, J.W., and Mestl, G.E., 1989, Missouri River fishery resources in relation to past, present, and future stresses, in Dodge, D.P., ed., Proceedings of the International Large River Symposium: Canadian Special Publication of Fisheries and Aquatic Sciences 106, p. 352-371.

Hesse, L.W., and Sheets, W., 1993, The Missouri River hydrosystem: Fisheries, v. 18, no. 5, p. 5-14.

Hurley, K.L., 1999, Habitat use, selection, and movements of Middle Mississippi River pallid sturgeon and validity of pallid sturgeon age estimates from pectoral fin rays: Carbondale, Southern Illinois University, M.S. thesis, 82 p.

Jacobson, R.B., Blevins, D.W., and Bitner, C.J., 2009a, Sediment regime constraints on river restoration-An example from the Lower Missouri River, in James, L.A., Rathburn, S.L., and Whittecar, G.R., eds., Management and restoration of fluvial systems with broad historical changes and human impacts: Geological Society of America Special Paper 451, p. $1-22$.

Jacobson, R.B., and Galat, D.L., 2006, Flow and form in rehabilitation of large-river ecosystems - An example from the Lower Missouri River: Geomorphology, v. 77, p. 249-269.

Jacobson, R.B., and Galat, D.L., 2008, Design of a naturalized flow regime-An example from the Lower Missouri River, USA: Ecohydrology, v. 1, p. 81-104.

Jacobson, R.B., and Heuser, J., 2002, Visualization of flow alternatives, Lower Missouri River: U.S. Geological Survey Open-File Report 2002-122.

Jacobson, R.B., Johnson, H.E., III, and Dietsch, B.J., 2009b, Hydrodynamic simulations of physical aquatic habitat availability for pallid sturgeon in the Lower Missouri River, at Yankton, South Dakota, Kenslers Bend, Nebraska, Little Sioux, Iowa, and Miami, Missouri, 2006-07: U.S. Geological Survey Scientific Investigations Report 2009-5058, $67 \mathrm{p}$.
Jacobson, R.B., Johnson, H.E., Laustrup, M.S., D’Urso, G.J., and Reuter, J.M., 2004, Physical habitat dynamics in four side-channel chutes, Lower Missouri River: U.S. Geological Survey Open-File Report 2004-1071, 60 p.

Jacobson, R.B., Johnson, H.E., Reuter, J.M., and Elliott, C.M., 2007, The roles of physical habitat in reproduction and survival of pallid sturgeon and shovelnose sturgeon in the Lower Missouri River, progress 2005-06, in Korschgen, C.E., ed., Factors affecting the reproduction, recruitment, habitat, and population dynamics of pallid sturgeon and shovelnose sturgeon in the Missouri River: U.S. Geological Survey Open-File Report 2007-1262, p. 143-212.

Jacobson, R.B., Laustrup, M.S., and Chapman, M.D., 2001, Fluvial processes and passive rehabilitation of the Lisbon Bottom side-channel chute, Lower Missouri River, in Dorava, J.M., Montgomery, D.R., Palcsak, B.B., and Fitzpatrick, F.A., eds., Geomorphic processes and riverine habitat: American Geophysical Union Water Science and Application Series, p. 199-216.

June, F.C., 1977, Reproductive patterns in seventeen species of warmwater fishes in a Missouri River reservoir: Environmental Biology of Fishes, v. 2, no. 3, p. 285-296.

Keenlyne, K.D., 1997, Life history and status of the shovelnose sturgeon, Scaphirhynchus platorynchus: Environmental Biology of Fishes, v. 48, p. 291-298.

Keenlyne, K.D., and Jenkins, L.G., 1993, Age at sexual maturity of the pallid sturgeon: Transactions of the American Fisheries Society, v. 122, p. 393-396.

Kolar, C.S., Chapman, D.C., Courtenay, W.R., Jr., Housel, C.M., Williams, J.D., and Jennings, D.P., 2007, Bighead carps - A biological synopsis and environmental risk assessment: Herndon, Va., American Fisheries Society Special Publication 33, 204 p.

Korschgen, C.E., ed., 2007, Factors affecting the reproduction, recruitment, habitat, and population dynamics of pallid sturgeon and shovelnose sturgeon in the Missouri River: U.S. Geological Survey Open-File Report 2007-1262, 279 p.

Laustrup, M.S., Jacobson, R.B., and Simpkins, D.G., 2007, Distribution of potential spawning habitat for sturgeon in the Lower Missouri River, 2003-06: U.S. Geological Survey Open-File Report 2007-1192, 26 p.

Lundblad, E.R., Wright, D.J., Miller, J., Larkin, E.M., Rinehart, R., Naar, D.F., Donahue, B.T., Anderson, S.M., and Battista, T., 2006, A benthic terrain classification scheme for American Somoa: Marine Geodesy, v. 29, p. 89-111. 
Manly, B.F.J., McDonald, L.L., Thomas, D.L., McDonald, T.L., and Erickson, W.P., 2002, Resource selection by animals - Statistical design and analysis for field studies (2nd ed.): Dordrecht, the Netherlands, Kluwer Academic Publishers, $221 \mathrm{p}$.

Mayden, R.L., and Kuhajda, B.R., 1997, Threatened fishes of the world: Scaphirhynchus albus (Forbes \& Richardson, 1905) (Acipenseridae): Environmental Biology of Fishes, v. 48 , p. $420-421$.

Moos, R.E., 1978, Movement and reproduction of shovelnose sturgeon, Scaphirhynchus platorynchus (Rafinesque), in the Missouri River, South Dakota: Vermillion, University of South Dakota, Ph.D. dissertation, 216 p.

National Research Council, 2002, The Missouri River ecosystem-Exploring the prospects for recovery: Washington, D.C., National Academy Press, 176 p.

Nestler, J.M., Goodwin, R.A., Smith, D.L., Anderson, J.J., and Li, S., 2008, Optimum fish passage and guidance designs are based in the hydrogeomorphology of natural rivers: River Research and Applications, v. 24, p. 148-168.

Orth, D.J., and White, R.J., 1999, Stream habitat management, in Kohler, C.C., and Hubert, W.A., eds., Inland fisheries management in North America: (2nd ed.) Bethesda, Md., American Fisheries Society, p. 249-284.

Papoulias, D.M., Annis, M.L., DeLonay, A.J., and Tillitt, D.E., 2007, Reproductive physiology of Missouri River gravid pallid sturgeon and shovelnose sturgeon during the 2005 and 2006 spawning seasons, in Korschgen, C.E., ed., Factors affecting the reproduction, recruitment, habitat, and population dynamics of pallid sturgeon and shovelnose sturgeon in the Missouri River: U.S. Geological Survey Open-File Report 2007-1262, p. 107-136.

Pegg, M.A., Pierce, C.L., and Roy, A., 2003, Hydrological alteration along the Missouri River Basin-A time series approach: Aquatic Sciences, v. 65, p. 63-72.

Pflieger, W.L., and Grace, T.B., 1987, Changes in the fish fauna of the Lower Missouri River, 1940-1983, in Mathews, W., and Heins, D., eds., Community and evolutionary ecology of North American stream fishes: Norman, Okla., University of Oklahoma Press, p. 166-177.

Poff, N.L., Allan, J.D., Bain, M.B., Karr, J.R., Prestegaard, K.L., Richter, B.D., Sparks, R.E., and Stromberg, J.C., 1997, The natural flow regime-A paradigm for river conservation and restoration: BioScience, v. 47, no. 11, p. 769-784.
Poulton, B.C., Wildhaber, M.L., Charbonneau, C.S., Fairchild, J.F., Mueller, B.G., and Schmitt, C.J., 2003, A longitudinal assessment of the aquatic macroinvertebrate community in the channelized Lower Missouri River: Environmental Monitoring and Assessment, v. 85, p. 23-53.

Quist, M.C., Boelter, A.M., Lovato, J.M., Korfanta, N.M., Bergman, H.L., Latka, D.C., Korschgen, C., Galat, D.L., Krentz, S., Oetker, M., Olson, M., Scott, C.M., and Berkley, J., 2004, Research and assessment needs for pallid sturgeon recovery in the Missouri River-Final report to the U.S. Geological Survey, U.S. Army Corps of Engineers, U.S. Fish and Wildlife Service, and U.S. Environmental Protection Agency: Laramie, Wyo., William D. Ruckelshaus Institute of Environment and Natural Resources, University of Wyoming, $82 \mathrm{p}$.

Quist, M.C., Guy, C.S., Pegg, M.A., Braaten, P.J., Pierce, C.L., and Travnichek, V.H., 2002, Potential influence of harvest on shovelnose sturgeon populations in the Missouri River system: North American Journal of Fisheries Management, v. 22, p. 537-549.

Rabeni, C.F., and Jacobson, R.B., 1993, The importance of fluvial hydraulics to fish-habitat restoration in low-gradient alluvial streams: Freshwater Biology, v. 29, p. 211-220.

Rabeni, C.F., and Jacobson, R.B., 1999, Warmwater streams, in Kohler, C.C., and Hubert, W.A., eds., Inland fisheries management in North America: Bethesda, Md., American Fisheries Society, p. 505-528.

Reuter, J.M., Jacobson, R.B., and Elliott, C.M., 2003, Physical stream habitat dynamics in Lower Bear Creek, Northern Arkansas: U.S. Geological Survey Biological Science Report 2003-0002, 49 p.

Reuter, J.M., Jacobson, R.B., Elliott, C.M., Johnson, H.E., III, and DeLonay, A.J., 2008, Hydraulic and substrate maps of reaches used by sturgeon (genus Scaphirhynchus) in the Lower Missouri River, 2005-07: U.S. Geological Survey Data Series 386, 442 p.

Snook, V.A., Peters, E.J., and Young, L.J., 2002, Movements and habitat use by hatchery-reared pallid sturgeon in the Lower Platte River, Nebraska: American Fisheries Society Symposium, v. 28, p. 161-174.

Sprague, L.A., Clark, M.L., Rus, D.L., Zelt, R.B., Flynn, J.L., and Davis, J.V., 2006, Nutrient and suspended-sediment trends in the Missouri River Basin, 1993-2003: U.S. Geological Survey Scientific Investigations Report 2006-5231, $80 \mathrm{p}$. 
Standen, E.M., Hinch, S.G., Healey, M.C., and Farrell, A.P., 2002, Energetic costs of migration through the Fraser River Canyon, British Columbia, in adult pink (Oncorhynchus gorbuscha) and sockeye (Oncorhynchus nerka) salmon as assessed by EMG telemetry: Canadian Journal of Fisheries and Aquatic Sciences, v. 29, p. 1,809-1,818.

U.S. Army Corps of Engineers, 2003, Final supplemental environmental impact statement for the Missouri River fish and wildlife mitigation project: U.S. Army Corps of Engineers., accessed on January 21, 2009, at http://www.nwk.usace. army.mil/projects/mitigation/seis-download.htm

U.S. Army Corps of Engineers, 2004, Summary Missouri River final environmental impact statement-Master water control manual review and update: U.S. Army Corps of Engineers-Northwestern Division, 32 p., accessed on January 21, 2009, at http://www.nwd-mr.usace.army.mil/ mmanual/Summary.pdf

U.S. Army Corps of Engineers, 2007, Missouri River stage trends-Reservoir Control Center technical report Ja-07: U.S. Army Corps of Engineers-Northwestern Division, 43 p., accessed on January 21, 2009, at http://www.nwd-mr. usace.army.mil/rcc/reports/pdfs/Ja07MRStageTrends.pdf

U.S. Fish and Wildlife Service, 2000, Biological opinion on the operation of the Missouri River main stem reservoir system, operation and maintenance of the Missouri River Bank Stabilization and Navigation Project, and operation of the Kansas River Reservoir System: U.S. Fish and Wildlife Service, 296 p., accessed on January 21, 2009, at http:// www.nwd-mr.usace.army.mil/mmanual/opinion.html
U.S. Fish and Wildlife Service, 2003, Amendment to the 2000 biological opinion on the operation of the Missouri River main stem reservoir system, operation and maintenance of the Missouri River Bank Stabilization and Navigation Project, and operation of the Kansas River Reservoir System: U.S. Fish and Wildlife Service., 308 p., accessed on January 21, 2009, at http://www.nwd-mr.usace.army.mil/mmanual/ FinalBO2003.pdf

Weiss, A.D., 2001, Topographic positions and landforms analysis [abs.]: Environmental Systems Research Institute, Inc. (ESRI) International User Conference, San Diego, Calif.

Wildhaber, M.L., DeLonay, A.J., Papoulias, D.M., Galat, D.L., Jacobson, R.B., Simpkins, D.G., Braaten, P.J., Korschgen, C.E., and Mac, M.J., 2007a, A conceptual life-history model for pallid and shovelnose sturgeon: U.S. Geological Survey Circular 1315, 19 p.

Wildhaber, M.L., Papoulias, D.M., DeLonay, A.J., Tillitt, D.E., Bryan, J.L., and Annis, M.L., 2007b, Physical and hormonal examination of Missouri River shovelnose sturgeon reproductive stage-A reference guide: Journal of Applied Ichthyology, v. 23, p. 382-401.

Wilson, J.A., and McKinley, R.S., 2004, Distribution, habitat, and movements, in LeBreton, G.T.O., Beamish, F.W.H., and McKinley, R.S., eds., Sturgeons and paddlefish of North America: Dordrecht, the Netherlands, Kluwer Academic Publishers, p. 40-72.

Yang Yu, Yan Zhong-min, and Chang Jian-bo, 2007, Computation and analysis of the cross-section mean vorticity in Chinese sturgeon spawning area: Advances in Water Science, v. 18, no. 5, p. 701-705. [In Chinese, English abstract.].

Yu, S.L., and Peters, E.J., 1997, Use of Froude number to determine habitat selection by fish: Rivers, v. 6, p. 10-18. 

Table 4 
Table 4. Reach map data for sturgeon relocations on reach maps within 7 days and 10 percent discharge.

[m, meter; m/s, meter per second; SWH, shallow-water habitat (depth $<1.5 \mathrm{~m}$, velocity $<0.6 \mathrm{~m} / \mathrm{s}$ ); $\mathrm{ft}^{3} / \mathrm{s}$, cubic foot per second; --, no data]

\begin{tabular}{|c|c|c|c|c|c|c|c|c|c|c|c|c|c|}
\hline $\begin{array}{l}\text { Sturgeon } \\
\text { identification } \\
\text { code }\end{array}$ & $\begin{array}{l}\text { River mile } \\
\text { of sturgeon } \\
\text { relocation }\end{array}$ & $\begin{array}{l}\text { Relocation } \\
\text { date }\end{array}$ & $\begin{array}{c}\text { Map } \\
\text { identification }\end{array}$ & $\begin{array}{l}\text { Depth } \\
\text { (m) }\end{array}$ & $\begin{array}{c}\text { Depth } \\
\text { slope } \\
\text { (degrees) }\end{array}$ & $\begin{array}{c}\text { Velocity } \\
(\mathrm{m} / \mathrm{s})\end{array}$ & $\begin{array}{c}\text { Velocity } \\
\text { gradient } \\
\text { (percent per } \\
\text { meter) } \\
\end{array}$ & $\begin{array}{l}\text { Froude } \\
\text { number }\end{array}$ & Substrate & SWH & $\begin{array}{l}\text { Terrain } \\
\text { class }\end{array}$ & $\begin{array}{c}\text { Estimated } \\
\text { discharge on } \\
\text { relocation date } \\
\left(\mathrm{ft}^{3} / \mathrm{s}\right)\end{array}$ & $\begin{array}{c}\text { Estimated } \\
\text { discharge } \\
\text { on map date } \\
\left(\mathrm{ft}^{3} / \mathbf{s}\right)\end{array}$ \\
\hline PLS05-006 & 808.3 & July 18,2006 & 20060711_f & 3.3 & 1.2 & 0.87 & 0.96 & 0.15 & -- & No & Flat & 25,500 & 25,500 \\
\hline PLS05-006 & 808.2 & July 10, 2006 & 20060711_f & 4.2 & 0.8 & 1.12 & 0.63 & 0.17 & -- & No & Flat & 25,500 & 25,500 \\
\hline SNS07-093 & 807.0 & May 15, 2007 & 20070516_f & 3.5 & 2.8 & 0.45 & 0.85 & 0.08 & -- & No & Depression & 8,000 & 8,000 \\
\hline SNS07-093 & 806.6 & May 23, 2007 & 20070524_f & 3.7 & 4.4 & 0.44 & 1.41 & 0.07 & -- & No & Depression & 11,300 & 11,000 \\
\hline SNS07-093 & 806.5 & May 21, 2007 & 20070524_f & 3.3 & 2.8 & 0.51 & 0.25 & 0.09 & -- & No & Depression & 11,000 & 11,000 \\
\hline SNS07-093 & 806.3 & May 27, 2007 & 20070524_f & 4.8 & 0.4 & 0.54 & 0.19 & 0.08 & -- & No & Depression & 12,000 & 11,000 \\
\hline SNS07-081 & 801.9 & May 9, 2007 & 20070510_f & 2.4 & 1.3 & 0.38 & 0.12 & 0.08 & -- & No & Depression & 8,000 & 8,000 \\
\hline SNS07-088 & 797.4 & May 25, 2007 & 20070601_f & 1.5 & 0.4 & 0.60 & 0.25 & 0.15 & -- & No & Flat & 21,500 & 19,600 \\
\hline SNS07-169 & 797.1 & May 25, 2007 & 20070601_f & 1.5 & 0.6 & 0.67 & 0.14 & 0.18 & -- & No & Flat & 21,500 & 19,600 \\
\hline SNS07-085 & 797.0 & May 31, 2007 & 20070601_f & 1.4 & 1.1 & 0.63 & 0.73 & 0.17 & -- & No & Flat & 20,800 & 19,600 \\
\hline SNS07-122 & 782.5 & May 17, 2007 & 20070518_f & 2.6 & 1.0 & 0.71 & 1.45 & 0.14 & -- & No & Flat & 20,100 & 18,900 \\
\hline SNS07-162 & 782.4 & May 23, 2007 & 20070518_f & 1.7 & 1.6 & 0.40 & 0.68 & 0.10 & -- & No & Flat & 18,500 & 18,900 \\
\hline SNS07-164 & 775.3 & May 27, 2007 & 20070530_f & 1.3 & 1.2 & 0.61 & 0.95 & 0.17 & -- & Yes & Crest & 17,700 & 17,000 \\
\hline SNS07-164 & 775.1 & May 29, 2007 & 20070530_f & 2.9 & 1.1 & 0.90 & 0.84 & 0.17 & -- & No & Flat & 17,700 & 17,000 \\
\hline SNS07-127 & 775.1 & May 29, 2007 & 20070530_f & 2.9 & 3.9 & 0.80 & 1.38 & 0.15 & -- & No & Flat & 17,700 & 17,000 \\
\hline SNS07-139 & 775.1 & May 29, 2007 & 20070530_f & 2.4 & 0.4 & 0.93 & 0.43 & 0.19 & -- & No & Flat & 17,700 & 17,000 \\
\hline SNS07-080 & 775.1 & May 27, 2007 & 20070530_f & 4.2 & 2.5 & 1.08 & 2.56 & 0.17 & -- & No & Depression & 17,700 & 17,000 \\
\hline SNS07-118 & 774.9 & June 2, 2007 & 20070530_f & 5.0 & 3.8 & 0.85 & 0.61 & 0.12 & -- & No & Depression & 16,500 & 17,000 \\
\hline SNS05-066 & 759.7 & June 14, 2005 & 20050615_f & 1.0 & 0.5 & 0.40 & 1.08 & 0.13 & -- & Yes & Crest & 27,300 & 27,500 \\
\hline PLS07-004 & 759.5 & May 20, 2007 & 20070521_f & 3.8 & 1.4 & 0.95 & 0.88 & 0.16 & -- & No & Depression & 23,400 & 23,700 \\
\hline PLS07-004 & 759.5 & May 20, 2007 & 20070521_f & 3.4 & 2.3 & 0.78 & 0.83 & 0.14 & -- & No & Flat & 23,400 & 23,700 \\
\hline SNS07-076 & 753.3 & May 24, 2007 & 20070523_f & 1.1 & 0.6 & 0.41 & 0.32 & 0.13 & -- & Yes & Flat & 23,500 & 25,300 \\
\hline SNS07-159 & 753.1 & May 24, 2007 & 20070523_f & 3.2 & 0.6 & 1.17 & 0.21 & 0.21 & -- & No & Depression & 23,500 & 25,300 \\
\hline SNS07-141 & 753.0 & May 20, 2007 & 20070523 f & 3.2 & 2.8 & 1.04 & 1.90 & 0.18 & -- & No & Depression & 23,400 & 25,300 \\
\hline SNS07-104 & 752.9 & May 24, 2007 & 20070523 f & 3.2 & 0.6 & 1.03 & 0.07 & 0.18 & -- & No & Depression & 23,500 & 25,300 \\
\hline SNS07-104 & 752.8 & May 20, 2007 & 20070523_f & 3.0 & 1.5 & 1.00 & 0.35 & 0.18 & -- & No & Depression & 23,400 & 25,300 \\
\hline SNS07-147 & 752.5 & May 24, 2007 & 20070523 f & 1.6 & 0.3 & 0.53 & 0.16 & 0.14 & -- & No & Crest & 23,500 & 25,300 \\
\hline SNS07-135 & 752.3 & May 20, 2007 & 20070523 f & 1.5 & 1.0 & 0.64 & 0.52 & 0.17 & -- & No & Crest & 23,400 & 25,300 \\
\hline SNS06-060 & 752.1 & June 16, 2006 & 20060622 f & 3.1 & 0.7 & 0.53 & 0.42 & 0.10 & Sand (dunes) & No & Depression & 27,400 & 26,800 \\
\hline SNS07-135 & 752.1 & May 16, 2007 & 20070523_f & 3.8 & 1.4 & 0.78 & 0.23 & 0.13 & -- & No & Depression & 26,600 & 25,300 \\
\hline SNS06-085 & 749.4 & June 26, 2006 & 20060620_f & 7.3 & 21.1 & 0.60 & 2.63 & 0.08 & -- & No & Depression & 26,300 & 26,400 \\
\hline SNS06-085 & 749.4 & June 14, 2006 & $20060620 \_f$ & 2.9 & 3.4 & 0.57 & 0.64 & 0.11 & -- & No & Flat & 26,400 & 26,400 \\
\hline SNS06-083 & 749.4 & June 14, 2006 & 20060620_f & 1.5 & 3.5 & 0.26 & 1.91 & 0.07 & -- & Yes & Crest & 26,400 & 26,400 \\
\hline
\end{tabular}


Table 4. Reach map data for sturgeon relocations on reach maps within 7 days and 10 percent discharge.-Continued

$\left[\mathrm{m}\right.$, meter; $\mathrm{m} / \mathrm{s}$, meter per second; SWH, shallow-water habitat (depth $<1.5 \mathrm{~m}$, velocity $<0.6 \mathrm{~m} / \mathrm{s}$ ); $\mathrm{ft}^{3} / \mathrm{s}$, cubic foot per second; --, no data]

\begin{tabular}{|c|c|c|c|c|c|c|c|c|c|c|c|c|c|}
\hline $\begin{array}{l}\text { Sturgeon } \\
\text { identification } \\
\text { code }\end{array}$ & $\begin{array}{l}\text { River mile } \\
\text { of sturgeon } \\
\text { relocation }\end{array}$ & $\begin{array}{l}\text { Relocation } \\
\text { date }\end{array}$ & $\begin{array}{c}\text { Map } \\
\text { identification }\end{array}$ & $\begin{array}{l}\text { Depth } \\
\text { (m) }\end{array}$ & $\begin{array}{c}\text { Depth } \\
\text { slope } \\
\text { (degrees) }\end{array}$ & $\begin{array}{c}\text { Velocity } \\
(\mathrm{m} / \mathrm{s})\end{array}$ & $\begin{array}{c}\text { Velocity } \\
\text { gradient } \\
\text { (percent per } \\
\text { meter) }\end{array}$ & $\begin{array}{l}\text { Froude } \\
\text { number }\end{array}$ & Substrate & SWH & $\begin{array}{l}\text { Terrain } \\
\text { class }\end{array}$ & $\begin{array}{c}\text { Estimated } \\
\text { discharge on } \\
\text { relocation date } \\
\left(\mathrm{ft}^{3} / \mathrm{s}\right)\end{array}$ & $\begin{array}{c}\text { Estimated } \\
\text { discharge } \\
\text { on map date } \\
\left(\mathrm{ft}^{3} / \mathbf{s}\right)\end{array}$ \\
\hline SNS06-083 & 749.4 & June 16,2006 & 20060620_f & 1.6 & 6.3 & -- & -- & -- & -- & -- & Crest & 27,400 & 26,400 \\
\hline SNS06-085 & 749.4 & June 20, 2006 & 20060620_f & 5.9 & 9.0 & 0.80 & 1.58 & 0.11 & -- & No & Depression & 26,400 & 26,400 \\
\hline SNS06-083 & 749.4 & June 20, 2006 & $20060620 \_f$ & 5.6 & 7.0 & 0.62 & 1.77 & 0.09 & -- & No & Depression & 26,400 & 26,400 \\
\hline SNS05-063 & 746.3 & June 9,2005 & 20050610_f & 3.7 & 6.0 & 0.65 & 2.84 & 0.11 & Sand (dunes) & No & Slope & 34,000 & 32,400 \\
\hline SNS07-089 & 745.3 & May 19, 2007 & $20070525 \_f$ & 1.8 & 1.3 & 0.80 & 0.22 & 0.19 & Sand (dunes) & No & Flat & 21,100 & 19,600 \\
\hline SNS06-083 & 743.8 & July 11,2006 & 20060712 f & 3.8 & 15.7 & 0.71 & 0.73 & 0.12 & $\begin{array}{l}\text { Revetment, gravel, } \\
\text { hard sand }\end{array}$ & No & Slope & 26,200 & 26,200 \\
\hline SNS06-085 & 743.3 & July 13, 2006 & 20060712_f & 5.4 & 5.0 & 0.78 & 1.27 & 0.11 & Sand (dunes) & No & Depression & 26,100 & 26,200 \\
\hline SNS06-085 & 743.2 & July 11,2006 & 20060712 f & 3.9 & 9.0 & 0.90 & 0.91 & 0.15 & Sand (dunes) & No & Slope & 26,200 & 26,200 \\
\hline SNS07-132 & 738.7 & May 4, 2007 & 20070502_f & 3.2 & 2.2 & 0.77 & 1.45 & 0.14 & Sand (dunes) & No & Depression & 12,700 & 12,100 \\
\hline SNS07-132 & 738.7 & May 1, 2007 & 20070502 f & 3.5 & 6.3 & 0.71 & 2.58 & 0.13 & $\begin{array}{l}\text { Revetment, gravel, } \\
\text { hard sand }\end{array}$ & No & Depression & 12,400 & 12,100 \\
\hline SNS07-137 & 738.4 & May 4, 2007 & 20070502_f & 1.5 & 1.8 & 0.65 & 0.71 & 0.17 & Sand (dunes) & No & Flat & 12,700 & 12,100 \\
\hline SNS07-162 & 738.2 & May 1, 2007 & $20070502 \_\mathrm{f}$ & 2.1 & 0.8 & 0.65 & 0.55 & 0.14 & Sand (dunes) & No & Flat & 12,400 & 12,100 \\
\hline SNS07-162 & 738.2 & May 2, 2007 & 20070502 f & 3.2 & 1.9 & 0.45 & 0.17 & 0.08 & $\begin{array}{l}\text { Fine sediment (mud, } \\
\text { silt) }\end{array}$ & No & Depression & 12,100 & 12,100 \\
\hline SNS07-162 & 738.2 & May 4, 2007 & 20070502 f & 1.9 & 0.5 & 0.51 & 0.70 & 0.12 & $\begin{array}{l}\text { Fine sediment (mud, } \\
\text { silt) }\end{array}$ & No & Flat & 12,700 & 12,100 \\
\hline SNS07-094 & 738.1 & May 1, 2007 & 20070502 f & 4.1 & 3.6 & 0.82 & 0.59 & 0.13 & Sand (dunes) & No & Depression & 12,400 & 12,100 \\
\hline SNS07-169 & 738.1 & May 1, 2007 & $20070502 \_f$ & 4.7 & 3.0 & 0.77 & 1.26 & 0.12 & Sand (dunes) & No & Depression & 12,400 & 12,100 \\
\hline SNS07-169 & 738.1 & May 2, 2007 & $20070502 \_f$ & 1.3 & 0.4 & 0.74 & 0.47 & 0.20 & Sand (dunes) & No & Crest & 12,100 & 12,100 \\
\hline SNS07-132 & 737.3 & May 8, 2007 & $20070509 \_f$ & 1.5 & 0.4 & 0.73 & 0.25 & 0.19 & Sand (dunes) & No & Crest & 13,700 & 15,000 \\
\hline SNS07-147 & 737.1 & May 8, 2007 & $20070509 \_\mathrm{f}$ & 2.7 & 3.0 & 0.37 & 0.37 & 0.07 & $\begin{array}{l}\text { Fine sediment (mud, } \\
\text { silt) }\end{array}$ & No & Depression & 13,700 & 15,000 \\
\hline SNS06-057 & 736.5 & May 8, 2007 & 20070509_f & 2.3 & 0.5 & 0.60 & 1.14 & 0.13 & Sand (dunes) & No & Flat & 13,700 & 15,000 \\
\hline SNS07-040 & 736.4 & May 8, 2007 & 20070509_f & 3.0 & 1.7 & 0.66 & 0.43 & 0.12 & Sand (dunes) & No & Depression & 13,700 & 15,000 \\
\hline SNS07-079 & 735.9 & May 8, 2007 & 20070509_f & 3.0 & 4.5 & 0.61 & 0.95 & 0.11 & Sand (dunes) & No & Depression & 13,700 & 15,000 \\
\hline SNS07-109 & 735.0 & May 5, 2007 & $20070503 \_f$ & 1.6 & 0.7 & 0.55 & 0.13 & 0.14 & $\begin{array}{l}\text { Revetment, gravel, } \\
\text { hard sand }\end{array}$ & No & Flat & 13,300 & 12,200 \\
\hline SNS07-126 & 735.0 & June 5, 2007 & 20070612_f & 3.3 & 2.9 & 0.86 & 1.12 & 0.15 & $\begin{array}{l}\text { Engineered structures } \\
\text { (rock) }\end{array}$ & No & Flat & 24,200 & 23,400 \\
\hline SNS07-107 & 735.0 & June 9, 2007 & 20070612_f & 3.2 & 2.1 & 0.75 & 0.30 & 0.13 & Sand (dunes) & No & Flat & 23,500 & 23,400 \\
\hline SNS07-089 & 734.9 & May 1, 2007 & 20070503 f & 5.8 & 17.4 & 0.48 & 1.06 & 0.06 & Sand (dunes) & No & Depression & 12,400 & 12,200 \\
\hline SNS07-109 & 734.9 & May 1, 2007 & 20070503 f & 1.6 & 0.3 & 0.69 & 0.20 & 0.17 & Sand (dunes) & No & Flat & 12,400 & 12,200 \\
\hline SNS07-138 & 734.9 & May 1, 2007 & $20070503 \_f$ & 2.6 & 12.5 & 0.44 & 0.37 & 0.09 & Sand (dunes) & No & Slope & 12,400 & 12,200 \\
\hline SNS07-089 & 734.9 & May 1, 2007 & 20070503 f & 7.1 & 15.2 & 0.52 & 1.35 & 0.06 & Sand (dunes) & No & Depression & 12,400 & 12,200 \\
\hline SNS07-123 & 734.9 & May 5, 2007 & $20070503 \_f$ & 7.5 & 8.5 & 0.58 & 0.72 & 0.07 & Sand (dunes) & No & Depression & 13,300 & 12,200 \\
\hline SNS07-109 & 734.9 & May 2, 2007 & 20070503 f & 5.5 & 5.6 & 0.63 & 0.48 & 0.09 & Transporting sand & No & Depression & 12,100 & 12,200 \\
\hline
\end{tabular}


Table 4. Reach map data for sturgeon relocations on reach maps within 7 days and 10 percent discharge.-Continued

$\left[\mathrm{m}\right.$, meter; $\mathrm{m} / \mathrm{s}$, meter per second; SWH, shallow-water habitat (depth $<1.5 \mathrm{~m}$, velocity $<0.6 \mathrm{~m} / \mathrm{s}$ ); $\mathrm{ft}^{3} / \mathrm{s}$, cubic foot per second; --, no data]

\begin{tabular}{|c|c|c|c|c|c|c|c|c|c|c|c|c|c|}
\hline $\begin{array}{l}\text { Sturgeon } \\
\text { identification } \\
\text { code }\end{array}$ & $\begin{array}{c}\text { River mile } \\
\text { of sturgeon } \\
\text { relocation }\end{array}$ & $\begin{array}{l}\text { Relocation } \\
\text { date }\end{array}$ & $\begin{array}{c}\text { Map } \\
\text { identification }\end{array}$ & $\begin{array}{l}\text { Depth } \\
\text { (m) }\end{array}$ & $\begin{array}{c}\text { Depth } \\
\text { slope } \\
\text { (degrees) }\end{array}$ & $\begin{array}{c}\text { Velocity } \\
\text { (m/s) }\end{array}$ & $\begin{array}{c}\text { Velocity } \\
\text { gradient } \\
\text { (percent per } \\
\text { meter) }\end{array}$ & $\begin{array}{l}\text { Froude } \\
\text { number }\end{array}$ & Substrate & SWH & $\begin{array}{l}\text { Terrain } \\
\text { class }\end{array}$ & $\begin{array}{c}\text { Estimated } \\
\text { discharge on } \\
\text { relocation date } \\
\left(\mathrm{ft}^{3} / \mathrm{s}\right)\end{array}$ & $\begin{array}{c}\text { Estimated } \\
\text { discharge } \\
\text { on map date } \\
\left(\mathrm{ft}^{3} / \mathrm{s}\right)\end{array}$ \\
\hline SNS07-138 & 734.9 & May 2, 2007 & 20070503 _f & 5.4 & 5.8 & 0.63 & 0.46 & 0.09 & Transporting sand & No & Depression & 12,100 & 12,200 \\
\hline SNS07-144 & 734.9 & May 2, 2007 & 20070503 f & 5.5 & 5.6 & 0.63 & 0.48 & 0.09 & Transporting sand & No & Depression & 12,100 & 12,200 \\
\hline SNS07-107 & 734.9 & June 19, 2007 & 20070612_f & 4.9 & 8.5 & 0.76 & 0.92 & 0.11 & Sand (dunes) & No & Depression & 23,400 & 23,400 \\
\hline SNS07-138 & 734.8 & May 5, 2007 & 20070503 f & 3.6 & 13.0 & 0.65 & 1.85 & 0.11 & Sand (dunes) & No & Depression & 13,300 & 12,200 \\
\hline SNS07-141 & 734.8 & May 1,2007 & $20070503 \_\mathrm{f}$ & 2.2 & 3.4 & 0.54 & 0.68 & 0.12 & Sand (dunes) & No & Flat & 12,400 & 12,200 \\
\hline SNS07-107 & 734.8 & June 14, 2007 & 20070612_f & 2.1 & 2.2 & 0.29 & 1.85 & 0.07 & Sand (dunes) & No & Crest & 23,800 & 23,400 \\
\hline SNS07-107 & 734.8 & June 13, 2007 & 20070612_f & 1.1 & 2.9 & 0.33 & 0.66 & 0.10 & $\begin{array}{l}\text { Revetment, gravel, } \\
\text { hard sand }\end{array}$ & Yes & Crest & 23,800 & 23,400 \\
\hline SNS07-107 & 734.8 & June 11, 2007 & 20070612_f & 2.8 & 1.2 & 0.90 & 0.31 & 0.17 & Sand (dunes) & No & Flat & 23,200 & 23,400 \\
\hline SNS07-073 & 734.7 & May 1, 2007 & $20070503 \_f$ & 5.8 & 2.9 & 1.01 & 0.89 & 0.13 & Sand (dunes) & No & Depression & 12,400 & 12,200 \\
\hline SNS07-073 & 734.7 & May 2, 2007 & $20070503 \_f$ & 4.3 & 0.8 & 0.91 & 0.60 & 0.14 & Sand (dunes) & No & Depression & 12,100 & 12,200 \\
\hline SNS07-154 & 734.6 & May 5, 2007 & 20070503 f & 4.6 & 7.4 & 0.65 & 0.52 & 0.10 & $\begin{array}{l}\text { Revetment, gravel, } \\
\text { hard sand }\end{array}$ & No & Depression & 13,300 & 12,200 \\
\hline SNS07-073 & 734.5 & May 5, 2007 & 20070503 f & 5.3 & 5.1 & 0.63 & 0.73 & 0.09 & $\begin{array}{l}\text { Revetment, gravel, } \\
\text { hard sand }\end{array}$ & No & Depression & 13,300 & 12,200 \\
\hline SNS07-154 & 734.5 & May 1, 2007 & $20070503 \_f$ & 5.9 & 4.9 & 0.61 & 0.93 & 0.08 & Sand (dunes) & No & Depression & 12,400 & 12,200 \\
\hline SNS07-165 & 734.5 & May 1, 2007 & $20070503 \_f$ & 5.0 & 2.5 & 0.65 & 0.43 & 0.09 & Sand (dunes) & No & Depression & 12,400 & 12,200 \\
\hline SNS07-118 & 734.5 & June 14, 2007 & 20070612_f & 3.3 & 4.2 & 0.88 & 1.68 & 0.15 & $\begin{array}{l}\text { Engineered structures } \\
\quad \text { (rock) }\end{array}$ & No & Flat & 23,800 & 23,400 \\
\hline SNS07-165 & 734.3 & May 2, 2007 & 20070503_f & 1.6 & 1.0 & 0.59 & 0.19 & 0.15 & Sand (dunes) & No & Crest & 12,100 & 12,200 \\
\hline SNS07-154 & 734.3 & May 2, 2007 & $20070503 \_\mathrm{f}$ & 2.8 & 0.8 & 0.82 & 0.53 & 0.16 & Sand (dunes) & No & Depression & 12,100 & 12,200 \\
\hline SNS07-084 & 734.2 & May 1,2007 & $20070503 \_f$ & 1.9 & 0.8 & 0.75 & 0.03 & 0.17 & Sand (dunes) & No & Flat & 12,400 & 12,200 \\
\hline SNS07-145 & 734.2 & May 5, 2007 & $20070503 \_f$ & 1.6 & 0.5 & 0.72 & 0.38 & 0.18 & Sand (dunes) & No & Crest & 13,300 & 12,200 \\
\hline SNS07-098 & 734.2 & May 1,2007 & $20070503 \_f$ & 4.3 & 6.3 & 0.68 & 0.29 & 0.10 & Sand (dunes) & No & Depression & 12,400 & 12,200 \\
\hline SNS07-072 & 734.2 & May 1, 2007 & 20070503 f & 5.1 & 2.8 & 0.57 & 0.48 & 0.08 & Sand (dunes) & No & Depression & 12,400 & 12,200 \\
\hline SNS07-166 & 734.0 & May 5, 2007 & 20070503_f & 2.0 & 0.2 & 0.84 & 0.30 & 0.19 & -- & No & Flat & 4,570 & 4,720 \\
\hline SNS07-116 & 734.0 & May 5, 2007 & 20070503_f & 3.3 & 1.9 & 0.59 & 0.99 & 0.10 & Sand (dunes) & No & Depression & 4,570 & 4,720 \\
\hline SNS07-164 & 734.0 & May 5, 2007 & $20070503 \_f$ & 4.3 & 1.9 & 0.95 & 0.57 & 0.15 & Sand (dunes) & No & Depression & 4,570 & 4,720 \\
\hline SNS07-129 & 734.0 & May 5, 2007 & $20070503 \_f$ & 3.5 & 1.8 & 0.90 & 1.44 & 0.15 & Sand (dunes) & No & Depression & 4,570 & 4,720 \\
\hline SNS07-129 & 734.0 & May 5, 2007 & 20070503_f & 3.0 & 3.2 & 0.89 & 0.72 & 0.17 & Sand (dunes) & No & Flat & 13,300 & 12,200 \\
\hline SNS07-098 & 734.0 & May 2, 2007 & 20070503_f & 4.2 & 0.5 & 0.85 & 0.39 & 0.13 & Sand (dunes) & No & Depression & 12,100 & 12,200 \\
\hline SNS07-139 & 734.0 & May 2, 2007 & $20070503 \_\mathrm{f}$ & 4.2 & 0.5 & 0.85 & 0.38 & 0.13 & Sand (dunes) & No & Depression & 12,100 & 12,200 \\
\hline
\end{tabular}


Table 4. Reach map data for sturgeon relocations on reach maps within 7 days and 10 percent discharge.-Continued

$\left[\mathrm{m}\right.$, meter; $\mathrm{m} / \mathrm{s}$, meter per second; SWH, shallow-water habitat (depth $<1.5 \mathrm{~m}$, velocity $<0.6 \mathrm{~m} / \mathrm{s}$ ); $\mathrm{ft}^{3} / \mathrm{s}$, cubic foot per second; --, no data]

\begin{tabular}{|c|c|c|c|c|c|c|c|c|c|c|c|c|c|}
\hline $\begin{array}{c}\text { Sturgeon } \\
\text { identification } \\
\text { code }\end{array}$ & $\begin{array}{c}\text { River mile } \\
\text { of sturgeon } \\
\text { relocation }\end{array}$ & $\begin{array}{l}\text { Relocation } \\
\text { date }\end{array}$ & $\begin{array}{c}\text { Map } \\
\text { identification }\end{array}$ & $\begin{array}{c}\text { Depth } \\
\text { (m) }\end{array}$ & $\begin{array}{c}\text { Depth } \\
\text { slope } \\
\text { (degrees) }\end{array}$ & $\begin{array}{c}\text { Velocity } \\
\text { (m/s) }\end{array}$ & $\begin{array}{c}\text { Velocity } \\
\text { gradient } \\
\text { (percent per } \\
\text { meter) }\end{array}$ & $\begin{array}{l}\text { Froude } \\
\text { number }\end{array}$ & Substrate & SWH & $\begin{array}{l}\text { Terrain } \\
\text { class }\end{array}$ & $\begin{array}{c}\text { Estimated } \\
\text { discharge on } \\
\text { relocation date } \\
\left(\mathrm{ft}^{3} / \mathbf{s}\right)\end{array}$ & $\begin{array}{c}\text { Estimated } \\
\text { discharge } \\
\text { on map date } \\
\left(\mathrm{ft}^{3} / \mathbf{s}\right)\end{array}$ \\
\hline SNS07-150 & 734.0 & May 2, 2007 & 20070503 f & 4.2 & 0.5 & 0.85 & 0.39 & 0.13 & Sand (dunes) & No & Depression & 12,100 & 12,200 \\
\hline SNS07-092 & 733.8 & May 5, 2007 & 20070503 f & 8.4 & 10.7 & 0.58 & 0.58 & 0.06 & $\begin{array}{l}\text { Revetment, gravel, } \\
\text { hard sand }\end{array}$ & No & Depression & 17,900 & 16,900 \\
\hline SNS07-166 & 733.8 & May 5, 2007 & 20070503_f & 9.4 & 9.1 & 0.52 & 1.25 & 0.05 & Sand (dunes) & No & Depression & 17,900 & 16,900 \\
\hline SNS07-150 & 733.8 & May 5, 2007 & $20070503 \_f$ & 9.3 & 9.4 & 0.52 & 1.14 & 0.05 & Sand (dunes) & No & Depression & 17,900 & 16,900 \\
\hline SNS07-094 & 733.8 & May 2, 2007 & 20070503_f & 7.9 & 13.2 & 0.54 & 0.90 & 0.06 & $\begin{array}{l}\text { Revetment, gravel, } \\
\text { hard sand }\end{array}$ & No & Depression & 17,100 & 16,900 \\
\hline SNS07-092 & 733.8 & May 2, 2007 & 20070503 ff & 7.9 & 13.8 & 0.54 & 0.97 & 0.06 & $\begin{array}{l}\text { Revetment, gravel, } \\
\text { hard sand }\end{array}$ & No & Depression & 17,100 & 16,900 \\
\hline SNS07-084 & 733.8 & May 2, 2007 & 20070503 f & 7.9 & 13.2 & 0.54 & 0.90 & 0.06 & $\begin{array}{l}\text { Revetment, gravel, } \\
\text { hard sand }\end{array}$ & No & Depression & 17,100 & 16,900 \\
\hline SNS07-166 & 733.8 & May 2, 2007 & 20070503_f & 7.9 & 13.2 & 0.54 & 0.90 & 0.06 & $\begin{array}{l}\text { Revetment, gravel, } \\
\text { hard sand }\end{array}$ & No & Depression & 17,100 & 16,900 \\
\hline SNS07-170 & 733.8 & June 11, 2007 & 20070612_f & 3.5 & 0.9 & 0.68 & 0.83 & 0.12 & Sand (dunes) & No & Flat & 25,700 & 25,700 \\
\hline SNS07-170 & 733.8 & June 14, 2007 & 20070612 f & 9.5 & 8.2 & 0.70 & 1.63 & 0.07 & Sand (dunes) & No & Depression & 25,900 & 25,700 \\
\hline SNS07-154 & 733.8 & June 11, 2007 & 20070612_f & 3.5 & 7.4 & 0.80 & 2.65 & 0.13 & Sand (dunes) & No & Slope & 25,700 & 25,700 \\
\hline SNS07-170 & 733.8 & June 19, 2007 & 20070612_f & 3.9 & 1.9 & 0.81 & 0.40 & 0.13 & Transporting sand & No & Flat & 25,700 & 25,700 \\
\hline SNS07-153 & 733.7 & May 1, 2007 & 20070503_f & 3.1 & 0.2 & 0.79 & 0.22 & 0.14 & Sand (dunes) & No & Flat & 17,800 & 16,900 \\
\hline SNS07-149 & 733.7 & May 2, 2007 & $20070503 \_\mathrm{f}$ & 3.1 & 0.4 & 0.75 & 0.18 & 0.14 & Sand (dunes) & No & Flat & 17,100 & 16,900 \\
\hline SNS07-143 & 733.7 & May 2, 2007 & 20070503_f & 3.1 & 0.4 & 0.75 & 0.18 & 0.14 & Sand (dunes) & No & Flat & 17,100 & 16,900 \\
\hline SNS07-075 & 733.6 & May 5, 2007 & 20070503 f & 4.6 & 4.7 & 0.79 & 0.54 & 0.12 & Sand (dunes) & No & Depression & 17,900 & 16,900 \\
\hline SNS07-075 & 733.6 & May 1,2007 & $20070503 \_f$ & 2.5 & 2.0 & 0.78 & 0.27 & 0.16 & Sand (dunes) & No & Crest & 17,800 & 16,900 \\
\hline SNS07-124 & 733.6 & May 1,2007 & 20070503 f & 2.6 & 0.4 & 0.85 & 0.15 & 0.17 & Sand (dunes) & No & Flat & 17,800 & 16,900 \\
\hline SNS07-100 & 733.6 & May 2, 2007 & 20070503_f & 2.6 & 0.6 & 0.87 & 0.33 & 0.17 & Sand (dunes) & No & Flat & 17,100 & 16,900 \\
\hline SNS07-072 & 733.6 & May 2, 2007 & 20070503 f & 2.2 & 2.4 & 0.56 & 1.54 & 0.12 & $\begin{array}{l}\text { Revetment, gravel, } \\
\text { hard sand }\end{array}$ & No & Crest & 17,100 & 16,900 \\
\hline SNS07-153 & 733.6 & May 2, 2007 & 20070503_f & 2.6 & 0.2 & 0.83 & 0.15 & 0.16 & Sand (dunes) & No & Flat & 17,100 & 16,900 \\
\hline SNS07-075 & 733.6 & May 2, 2007 & 20070503 f & 2.6 & 0.2 & 0.83 & 0.14 & 0.17 & Sand (dunes) & No & Flat & 17,100 & 16,900 \\
\hline SNS07-170 & 733.6 & June 9, 2007 & 20070612 f & 1.9 & 6.9 & & & & Sand (dunes) & -- & Crest & 26,200 & 25,700 \\
\hline SNS07-170 & 733.6 & June 8, 2007 & 20070612 f & 4.6 & 2.4 & 0.94 & 0.85 & 0.14 & Sand (dunes) & No & Depression & 26,700 & 25,700 \\
\hline SNS07-149 & 733.5 & May 5, 2007 & 20070503 f & 1.6 & 0.7 & 0.67 & 0.30 & 0.17 & Sand (dunes) & No & Crest & 17,900 & 16,900 \\
\hline SNS07-150 & 733.5 & June 6, 2007 & 20070612_f & 3.1 & 1.2 & 0.74 & 1.15 & 0.13 & Sand (dunes) & No & Crest & 27,000 & 25,700 \\
\hline SNS07-100 & 733.4 & May 5, 2007 & 20070503_f & 1.8 & 0.4 & 0.74 & 0.66 & 0.18 & $\begin{array}{l}\text { Engineered structures } \\
\quad \text { (rock) }\end{array}$ & No & Crest & 17,900 & 16,900 \\
\hline SNS07-143 & 733.4 & May 1, 2007 & 20070503 f & 2.5 & 2.3 & 0.77 & 0.39 & 0.16 & Sand (dunes) & No & Flat & 17,800 & 16,900 \\
\hline SNS07-170 & 733.4 & June 7, 2007 & 20070612_f & 4.8 & 1.8 & 1.10 & 0.16 & 0.16 & Sand (dunes) & No & Depression & 26,800 & 25,700 \\
\hline SNS07-144 & 733.4 & June 9, 2007 & 20070612_f & 4.5 & 6.5 & 0.78 & 1.71 & 0.12 & $\begin{array}{l}\text { Engineered structures } \\
\quad \text { (rock) }\end{array}$ & No & Depression & 26,200 & 25,700 \\
\hline
\end{tabular}


Table 4. Reach map data for sturgeon relocations on reach maps within 7 days and 10 percent discharge.-Continued

$\left[\mathrm{m}\right.$, meter; $\mathrm{m} / \mathrm{s}$, meter per second; SWH, shallow-water habitat (depth $<1.5 \mathrm{~m}$, velocity $<0.6 \mathrm{~m} / \mathrm{s}$ ); $\mathrm{ft}^{3} / \mathrm{s}$, cubic foot per second; --, no data]

\begin{tabular}{|c|c|c|c|c|c|c|c|c|c|c|c|c|c|}
\hline $\begin{array}{c}\text { Sturgeon } \\
\text { identification } \\
\text { code }\end{array}$ & $\begin{array}{l}\text { River mile } \\
\text { of sturgeon } \\
\text { relocation }\end{array}$ & $\begin{array}{l}\text { Relocation } \\
\text { date }\end{array}$ & $\begin{array}{c}\text { Map } \\
\text { identification }\end{array}$ & $\begin{array}{l}\text { Depth } \\
\text { (m) }\end{array}$ & $\begin{array}{c}\text { Depth } \\
\text { slope } \\
\text { (degrees) }\end{array}$ & $\begin{array}{c}\text { Velocity } \\
(\mathrm{m} / \mathrm{s})\end{array}$ & $\begin{array}{c}\text { Velocity } \\
\text { gradient } \\
\text { (percent per } \\
\text { meter) }\end{array}$ & $\begin{array}{l}\text { Froude } \\
\text { number }\end{array}$ & Substrate & SWH & $\begin{array}{l}\text { Terrain } \\
\text { class }\end{array}$ & $\begin{array}{c}\text { Estimated } \\
\text { discharge on } \\
\text { relocation date } \\
\left(\mathrm{ft}^{3} / \mathrm{s}\right)\end{array}$ & $\begin{array}{c}\text { Estimated } \\
\text { discharge } \\
\text { on map date } \\
\left(\mathrm{ft}^{3} / \mathrm{s}\right)\end{array}$ \\
\hline SNS07-133 & 733.3 & May 1, 2007 & $20070503 \_f$ & 3.1 & 2.7 & 0.64 & 1.15 & 0.12 & Sand (dunes) & No & Flat & 17,800 & 16,900 \\
\hline SNS07-124 & 733.3 & May 5, 2007 & $20070503 \_f$ & 3.4 & 1.8 & 0.59 & 1.14 & 0.10 & Sand (dunes) & No & Depression & 17,900 & 16,900 \\
\hline SNS05-084 & 732.4 & June 15, 2005 & 20050616_f & 4.9 & 2.9 & & & & -- & -- & Depression & 32,400 & 32,900 \\
\hline SNS07-079 & 730.2 & June 22, 2007 & 20070615_f & 4.8 & 13.8 & 0.85 & 3.54 & 0.13 & $\begin{array}{l}\text { Engineered structures } \\
\text { (rock) }\end{array}$ & No & Depression & 26,500 & 26,900 \\
\hline SNS07-079 & 730.2 & June 9, 2007 & 20070615_f & 3.6 & 11.7 & 0.69 & 2.68 & 0.12 & $\begin{array}{l}\text { Engineered structures } \\
\text { (rock) }\end{array}$ & No & Slope & 27,300 & 26,900 \\
\hline SNS07-079 & 730.2 & June 14, 2007 & 20070615_f & 5.0 & 11.1 & 0.83 & 4.48 & 0.13 & $\begin{array}{l}\text { Engineered structures } \\
\text { (rock) }\end{array}$ & No & Depression & 27,500 & 26,900 \\
\hline SNS07-079 & 730.1 & June 20, 2007 & 20070615_f & 5.8 & 10.1 & 1.04 & 3.95 & 0.14 & $\begin{array}{l}\text { Engineered structures } \\
\text { (rock) }\end{array}$ & No & Depression & 26,800 & 26,900 \\
\hline SNS07-079 & 730.1 & June 11, 2007 & 20070615_f & 5.9 & 3.6 & 1.14 & 2.88 & 0.15 & Sand (dunes) & No & Depression & 26,800 & 26,900 \\
\hline SNS07-157 & 729.8 & June 20, 2007 & 20070615_f & 4.1 & 3.4 & 0.94 & 1.99 & 0.15 & $\begin{array}{l}\text { Engineered structures } \\
\text { (rock) }\end{array}$ & No & Flat & 26,800 & 26,900 \\
\hline SNS07-157 & 729.2 & June 14, 2007 & 20070615_f & 5.0 & 7.4 & 0.90 & 3.40 & 0.13 & Sand (dunes) & No & Depression & 27,500 & 26,900 \\
\hline SNS07-157 & 729.0 & June 11, 2007 & 20070615_f & 2.8 & 6.6 & 0.71 & 1.98 & 0.14 & $\begin{array}{l}\text { Engineered structures } \\
\quad \text { (rock) }\end{array}$ & No & Slope & 26,800 & 26,900 \\
\hline SNS07-100 & 729.0 & June 11, 2007 & 20070615_f & 3.3 & 1.9 & 0.69 & 1.35 & 0.12 & -- & No & Flat & 26,800 & 26,900 \\
\hline SNS07-124 & 728.9 & June 20, 2007 & 20070615_f & 4.9 & 5.1 & 0.92 & 1.24 & 0.13 & Sand (dunes) & No & Depression & 26,800 & 26,900 \\
\hline SNS07-157 & 728.8 & June 9, 2007 & 20070615_f & 3.1 & 0.8 & 0.68 & 1.55 & 0.12 & $\begin{array}{l}\text { Engineered structures } \\
\text { (rock) }\end{array}$ & No & Flat & 27,300 & 26,900 \\
\hline SNS07-133 & 728.8 & June 9, 2007 & 20070615_f & 3.2 & 0.3 & 1.18 & 0.14 & 0.21 & Sand (dunes) & No & Flat & 27,300 & 26,900 \\
\hline SNS07-106 & 728.6 & June 14, 2007 & 20070615_f & 1.6 & 1.9 & 0.81 & 3.05 & 0.20 & Sand (dunes) & No & Crest & 27,500 & 26,900 \\
\hline SNS07-124 & 728.6 & June 14, 2007 & 20070615_f & 4.0 & 6.7 & 0.69 & 2.87 & 0.11 & Sand (dunes) & No & Depression & 27,500 & 26,900 \\
\hline SNS07-106 & 728.6 & June 20, 2007 & 20070615_f & 1.1 & 3.0 & 0.47 & 1.95 & 0.14 & Sand (dunes) & Yes & Crest & 26,800 & 26,900 \\
\hline SNS07-106 & 728.6 & June 22, 2007 & 20070615_f & 1.2 & 2.0 & 0.49 & 1.67 & 0.14 & Sand (dunes) & Yes & Crest & 26,500 & 26,900 \\
\hline SNS07-155 & 727.1 & May 1, 2007 & $20070504 \_f$ & 2.5 & 3.6 & 0.72 & 1.18 & 0.14 & $\begin{array}{l}\text { Revetment, gravel, } \\
\text { hard sand }\end{array}$ & No & Flat & 19,600 & 19,200 \\
\hline PLS07-008 & 726.6 & May 3, 2007 & 20070504_f & 3.4 & 1.1 & 1.15 & 0.47 & 0.20 & Sand (dunes) & No & Flat & 18,600 & 19,200 \\
\hline PLS07-008 & 726.6 & May 4, 2007 & 20070504_f & 3.4 & 1.1 & 1.15 & 0.49 & 0.20 & Sand (dunes) & No & Flat & 19,200 & 19,200 \\
\hline PLS07-008 & 726.6 & May 3, 2007 & 20070504_f & 3.0 & 7.8 & 0.73 & 2.54 & 0.13 & $\begin{array}{l}\text { Engineered structures } \\
\text { (rock) }\end{array}$ & No & Slope & 18,600 & 19,200 \\
\hline PLS07-008 & 726.6 & May 3, 2007 & 20070504_f & 3.4 & 1.1 & 1.15 & 0.49 & 0.20 & Sand (dunes) & No & Flat & 18,600 & 19,200 \\
\hline
\end{tabular}


Table 4. Reach map data for sturgeon relocations on reach maps within 7 days and 10 percent discharge.-Continued

$\left[\mathrm{m}\right.$, meter; $\mathrm{m} / \mathrm{s}$, meter per second; SWH, shallow-water habitat (depth $<1.5 \mathrm{~m}$, velocity $<0.6 \mathrm{~m} / \mathrm{s}$ ); $\mathrm{ft}^{3} / \mathrm{s}$, cubic foot per second; --, no data]

\begin{tabular}{|c|c|c|c|c|c|c|c|c|c|c|c|c|c|}
\hline $\begin{array}{c}\text { Sturgeon } \\
\text { identification } \\
\text { code }\end{array}$ & $\begin{array}{l}\text { River mile } \\
\text { of sturgeon } \\
\text { relocation }\end{array}$ & $\begin{array}{l}\text { Relocation } \\
\text { date }\end{array}$ & $\begin{array}{c}\text { Map } \\
\text { identification }\end{array}$ & $\begin{array}{l}\text { Depth } \\
\text { (m) }\end{array}$ & $\begin{array}{c}\text { Depth } \\
\text { slope } \\
\text { (degrees) }\end{array}$ & $\begin{array}{c}\text { Velocity } \\
(\mathrm{m} / \mathrm{s})\end{array}$ & $\begin{array}{c}\text { Velocity } \\
\text { gradient } \\
\text { (percent per } \\
\text { meter) }\end{array}$ & $\begin{array}{l}\text { Froude } \\
\text { number }\end{array}$ & Substrate & SWH & $\begin{array}{l}\text { Terrain } \\
\text { class }\end{array}$ & $\begin{array}{c}\text { Estimated } \\
\text { discharge on } \\
\text { relocation date } \\
\left(\mathrm{ft}^{3} / \mathrm{s}\right)\end{array}$ & $\begin{array}{c}\text { Estimated } \\
\text { discharge } \\
\text { on map date } \\
\left(\mathrm{ft}^{3} / \mathbf{s}\right)\end{array}$ \\
\hline PLS07-008 & 726.6 & May 3, 2007 & 20070504_f & 3.4 & 1.1 & 1.15 & 0.46 & 0.20 & Sand (dunes) & No & Flat & 18,600 & 19,200 \\
\hline SNS07-155 & 726.6 & May 3, 2007 & 20070504_f & 7.0 & 15.8 & 0.39 & 2.74 & 0.05 & $\begin{array}{l}\text { Engineered structures } \\
\quad \text { (rock) }\end{array}$ & No & Depression & 18,600 & 19,200 \\
\hline PLS07-008 & 726.5 & May 4, 2007 & 20070504_f & 2.6 & 0.3 & 1.08 & 0.51 & 0.21 & Sand (dunes) & No & Crest & 19,200 & 19,200 \\
\hline PLS07-008 & 726.5 & May 4, 2007 & 20070504_f & 2.6 & 0.4 & 1.07 & 0.78 & 0.21 & Sand (dunes) & No & Crest & 19,200 & 19,200 \\
\hline PLS07-008 & 726.5 & May 5, 2007 & 20070504_f & 2.9 & 0.4 & 1.07 & 0.18 & 0.20 & Sand (dunes) & No & Flat & 19,400 & 19,200 \\
\hline SNS07-098 & 726.3 & May 3, 2007 & 20070504_f & 2.4 & 2.0 & 0.91 & 0.64 & 0.19 & Sand (dunes) & No & Crest & 18,600 & 19,200 \\
\hline SNS07-155 & 726.2 & May 5, 2007 & 20070504_f & 2.7 & 2.7 & 0.95 & 0.87 & 0.19 & Sand (dunes) & No & Flat & 19,400 & 19,200 \\
\hline SNS06-058 & 724.8 & May 22, 2006 & 20060523 f & 4.6 & 8.3 & 0.62 & 3.10 & 0.09 & Transporting sand & No & Depression & 25,400 & 25,200 \\
\hline SNS07-040 & 724.8 & May 29, 2007 & $20070602 \_f$ & 4.1 & 1.3 & 0.99 & 0.41 & 0.16 & Sand (dunes) & No & Flat & 24,300 & 26,500 \\
\hline PLS07-003 & 724.8 & May 29, 2007 & 20070602 f & 4.1 & 6.1 & 1.18 & 2.21 & 0.19 & $\begin{array}{l}\text { Engineered structures } \\
\quad \text { (rock) }\end{array}$ & No & Slope & 24,300 & 26,500 \\
\hline SNS07-040 & 724.8 & May 31, 2007 & 20070602_f & 4.3 & 1.0 & 0.90 & 0.55 & 0.14 & Sand (dunes) & No & Flat & 24,200 & 26,500 \\
\hline SNS07-040 & 724.7 & June 7, 2007 & 20070602_f & 9.7 & 5.5 & 0.89 & 2.60 & 0.09 & Sand (dunes) & No & Depression & 27,600 & 26,500 \\
\hline SNS07-059 & 724.5 & June 9, 2007 & 20070602 f & 3.1 & 9.5 & 1.02 & 1.12 & 0.18 & $\begin{array}{l}\text { Engineered structures } \\
\text { (rock) }\end{array}$ & No & Crest & 27,300 & 26,500 \\
\hline SNS07-059 & 724.5 & June 6, 2007 & 20070602 f & 4.4 & 4.9 & 1.05 & 1.07 & 0.16 & $\begin{array}{l}\text { Engineered structures } \\
\quad \text { (rock) }\end{array}$ & No & Flat & 27,800 & 26,500 \\
\hline SNS07-059 & 724.5 & May 31, 2007 & 20070602_f & 3.6 & 8.1 & 1.03 & 1.13 & 0.17 & $\begin{array}{l}\text { Engineered structures } \\
\quad \text { (rock) }\end{array}$ & No & Slope & 24,200 & 26,500 \\
\hline SNS07-059 & 724.5 & June 8, 2007 & 20070602 f & 3.1 & 9.5 & 1.03 & 0.98 & 0.19 & $\begin{array}{l}\text { Engineered structures } \\
\text { (rock) }\end{array}$ & No & Crest & 27,600 & 26,500 \\
\hline SNS07-059 & 724.5 & May 29, 2007 & 20070602_f & 5.1 & 6.2 & 1.05 & 1.72 & 0.15 & Sand (dunes) & No & Depression & 24,300 & 26,500 \\
\hline SNS07-059 & 724.4 & June 7, 2007 & 20070602_f & 3.1 & 8.9 & 0.92 & 1.35 & 0.16 & $\begin{array}{l}\text { Engineered structures } \\
\quad \text { (rock) }\end{array}$ & No & Crest & 27,600 & 26,500 \\
\hline SNS07-040 & 724.4 & June 8, 2007 & 20070602_f & 2.1 & 0.6 & 0.77 & 0.97 & 0.17 & Sand (dunes) & No & Crest & 27,600 & 26,500 \\
\hline PLS07-004 & 718.2 & June 9, 2007 & 20070609_f & 2.4 & 4.0 & 0.74 & 1.13 & 0.15 & Sand (dunes) & No & Crest & 27,300 & 27,300 \\
\hline SNS07-072 & 717.8 & June 8, 2007 & $20070609 \_f$ & 4.0 & 1.2 & 1.07 & 0.41 & 0.17 & Transporting sand & No & Flat & 27,600 & 27,300 \\
\hline SNS07-171 & 717.8 & June 9, 2007 & $20070609 \_f$ & 2.7 & 10.2 & 0.97 & 0.70 & 0.18 & $\begin{array}{l}\text { Revetment, gravel, } \\
\text { hard sand }\end{array}$ & No & Crest & 27,300 & 27,300 \\
\hline SNS07-171 & 717.8 & June 6, 2007 & $20070609 \_\mathrm{f}$ & 4.3 & 10.3 & 0.89 & 2.70 & 0.14 & Sand (dunes) & No & Depression & 27,800 & 27,300 \\
\hline SNS07-171 & 717.8 & June 7, 2007 & $20070609 \_f$ & 3.9 & 11.9 & 0.87 & 3.07 & 0.14 & $\begin{array}{l}\text { Revetment, gravel, } \\
\text { hard sand }\end{array}$ & No & Slope & 27,600 & 27,300 \\
\hline SNS07-171 & 717.7 & June 8, 2007 & 20070609_f & 4.1 & 1.2 & 1.04 & 0.77 & 0.17 & Sand (dunes) & No & Flat & 27,600 & 27,300 \\
\hline SNS06-051 & 709.8 & May 31, 2006 & 20060607_f & 3.4 & 1.6 & 0.82 & 1.42 & 0.14 & Sand (dunes) & No & Flat & 26,400 & 26,800 \\
\hline SNS06-058 & 708.6 & May 31, 2006 & 20060607_f & 4.6 & 10.1 & 0.67 & 2.00 & 0.10 & Sand (dunes) & No & Slope & 26,400 & 26,800 \\
\hline SNS07-111 & 708.2 & June 12, 2007 & 20070613_f & 4.0 & 1.4 & 1.08 & 0.50 & 0.17 & Sand (dunes) & No & Flat & 26,700 & 26,900 \\
\hline SNS07-111 & 708.2 & June 7, 2007 & 20070613_f & 3.5 & 0.4 & 1.09 & 0.23 & 0.19 & Transporting sand & No & Flat & 27,600 & 26,900 \\
\hline
\end{tabular}


Table 4. Reach map data for sturgeon relocations on reach maps within 7 days and 10 percent discharge.-Continued

$\left[\mathrm{m}\right.$, meter; $\mathrm{m} / \mathrm{s}$, meter per second; SWH, shallow-water habitat (depth $<1.5 \mathrm{~m}$, velocity $<0.6 \mathrm{~m} / \mathrm{s}$ ); $\mathrm{ft}^{3} / \mathrm{s}$, cubic foot per second; --, no data]

\begin{tabular}{|c|c|c|c|c|c|c|c|c|c|c|c|c|c|}
\hline $\begin{array}{l}\text { Sturgeon } \\
\text { identification } \\
\text { code }\end{array}$ & $\begin{array}{l}\text { River mile } \\
\text { of sturgeon } \\
\text { relocation }\end{array}$ & $\begin{array}{l}\text { Relocation } \\
\text { date }\end{array}$ & $\begin{array}{c}\text { Map } \\
\text { identification }\end{array}$ & $\begin{array}{l}\text { Depth } \\
\text { (m) }\end{array}$ & $\begin{array}{c}\text { Depth } \\
\text { slope } \\
\text { (degrees) }\end{array}$ & $\begin{array}{l}\text { Velocity } \\
(\mathrm{m} / \mathrm{s})\end{array}$ & $\begin{array}{c}\text { Velocity } \\
\text { gradient } \\
\text { (percent per } \\
\text { meter) }\end{array}$ & $\begin{array}{l}\text { Froude } \\
\text { number }\end{array}$ & Substrate & SWH & $\begin{array}{l}\text { Terrain } \\
\text { class }\end{array}$ & $\begin{array}{c}\text { Estimated } \\
\text { discharge on } \\
\text { relocation date } \\
\left(\mathrm{ft}^{3} / \mathrm{s}\right)\end{array}$ & $\begin{array}{c}\text { Estimated } \\
\text { discharge } \\
\text { on map date } \\
\left(\mathrm{ft}^{3} / \mathrm{s}\right)\end{array}$ \\
\hline SNS07-111 & 708.1 & June 10, 2007 & 20070613_f & 3.6 & 1.0 & 1.05 & 0.13 & 0.18 & Sand (dunes) & No & Flat & 27,000 & 26,900 \\
\hline SNS07-175 & 707.4 & June 8, 2007 & 20070613_f & 4.5 & 11.6 & 0.96 & 1.21 & 0.15 & Sand (dunes) & No & Depression & 27,600 & 26,900 \\
\hline SNS07-175 & 707.4 & June 6, 2007 & 20070613_f & 4.4 & 9.3 & 0.95 & 1.16 & 0.15 & Sand (dunes) & No & Depression & 27,800 & 26,900 \\
\hline SNS07-175 & 707.4 & June 7, 2007 & 20070613 f & 6.0 & 8.6 & 1.08 & 1.45 & 0.14 & Sand (dunes) & No & Depression & 27,600 & 26,900 \\
\hline SNS07-175 & 707.3 & June 10, 2007 & 20070613_f & 5.7 & 2.0 & 1.27 & 0.41 & 0.17 & Sand (dunes) & No & Depression & 27,000 & 26,900 \\
\hline SNS07-057 & 706.2 & May 14, 2007 & 20070515_f & 6.6 & 4.8 & 1.27 & 1.79 & 0.16 & -- & No & Depression & 33,900 & 35,200 \\
\hline SNS07-019 & 706.1 & May 16, 2007 & 20070515_f & 2.8 & 6.3 & 0.71 & 2.99 & 0.13 & -- & No & Crest & 33,400 & 35,200 \\
\hline SNS07-055 & 705.6 & May 16, 2007 & 20070515_f & 4.5 & 3.3 & 0.87 & 0.47 & 0.13 & -- & No & Flat & 33,400 & 35,200 \\
\hline SNS07-055 & 705.6 & May 14, 2007 & 20070515_f & 2.8 & 3.7 & 0.73 & 1.79 & 0.14 & -- & No & Crest & 33,900 & 35,200 \\
\hline SNS07-010 & 702.3 & June 8, 2007 & 20070607_f & 5.7 & 4.1 & 1.16 & 0.76 & 0.15 & Sand (dunes) & No & Depression & 27,600 & 27,600 \\
\hline SNS07-010 & 702.3 & June 6,2007 & 20070607 f & 5.7 & 5.1 & 1.23 & 0.43 & 0.16 & Sand (dunes) & No & Depression & 27,800 & 27,600 \\
\hline SNS07-010 & 702.3 & June 7, 2007 & 20070607_f & 2.5 & 11.6 & 0.99 & 1.36 & & -- & -- & Crest & 27,600 & 27,600 \\
\hline SNS07-055 & 702.1 & June 6, 2007 & 20070607_f & 4.5 & 3.7 & 0.73 & 1.28 & 0.11 & Sand (dunes) & No & Depression & 27,800 & 27,600 \\
\hline SNS05-071 & 693.4 & June 8, 2005 & 20050609_f & 7.2 & 2.4 & 0.86 & 1.58 & 0.10 & Sand (dunes) & No & Depression & 41,900 & 42,900 \\
\hline SNS05-071 & 693.0 & June 16,2005 & 20050617_f & 2.4 & 4.7 & 0.47 & 2.68 & 0.10 & Sand (dunes) & No & Crest & 34,100 & 34,200 \\
\hline PLS07-004 & 692.1 & May 12,2007 & 20070519_f & 2.6 & 8.4 & 0.76 & 2.06 & 0.16 & Sand (dunes) & No & Crest & 26,000 & 26,800 \\
\hline SNS07-021 & 692.0 & May 18,2007 & 20070519_f & 4.8 & 8.2 & 0.95 & 1.13 & 0.14 & Sand (dunes) & No & Depression & 28,500 & 26,800 \\
\hline SNS07-046 & 691.4 & May 24, 2007 & 20070519_f & 3.5 & 11.5 & 0.62 & 3.52 & 0.12 & Transporting sand & No & Slope & 29,700 & 26,800 \\
\hline SNS07-021 & 689.9 & May 16, 2007 & 20070517_f & 3.8 & 6.1 & 0.64 & 2.89 & 0.10 & -- & No & Slope & 33,400 & 30,900 \\
\hline SNS07-046 & 689.1 & May 16, 2007 & 20070517_f & 4.5 & 4.0 & 0.66 & 0.38 & 0.10 & -- & No & Flat & 33,400 & 30,900 \\
\hline SNS07-046 & 689.1 & May 14, 2007 & 20070517_f & 2.8 & 2.1 & 0.83 & 0.97 & 0.16 & -- & No & Crest & 33,900 & 30,900 \\
\hline SNS07-035 & 689.1 & May 14, 2007 & 20070517_f & 2.7 & 1.8 & 0.86 & 0.48 & 0.17 & -- & No & Crest & 33,900 & 30,900 \\
\hline SNS07-035 & 689.1 & May 16, 2007 & 20070517_f & 4.2 & 4.5 & 0.65 & 1.12 & 0.10 & -- & No & Slope & 33,400 & 30,900 \\
\hline SNS07-035 & 689.0 & May 21, 2007 & 20070517_f & 6.2 & 0.4 & 0.69 & 0.73 & 0.09 & -- & No & Depression & 28,600 & 30,900 \\
\hline SNS07-046 & 689.0 & May 21, 2007 & 20070517_f & 5.7 & 2.6 & 0.84 & 0.46 & 0.11 & -- & No & Depression & 28,600 & 30,900 \\
\hline SNS05-064 & 686.4 & May 17,2005 & 20050518_f & 0.0 & 0.0 & 0.61 & 0.74 & & -- & -- & -- & 24,100 & 23,900 \\
\hline SNS05-062 & 686.4 & May 17, 2005 & 20050518_f & 5.0 & 6.3 & 0.69 & 3.79 & 0.10 & Sand (dunes) & No & Depression & 24,100 & 23,900 \\
\hline SNS05-057 & 683.9 & June 17, 2005 & 20050624_f & 2.6 & 6.9 & 0.93 & 2.31 & 0.19 & $\begin{array}{l}\text { Engineered structures } \\
\text { (rock) }\end{array}$ & No & Crest & 34,200 & 31,900 \\
\hline SNS05-064 & 674.2 & May 9, 2005 & 20050510_f & 1.8 & 2.7 & 0.56 & 1.90 & 0.13 & Sand (dunes) & No & Crest & 25,700 & 26,400 \\
\hline SNS05-062 & 673.3 & May 9, 2005 & 20050510_f & 2.9 & 10.2 & 0.59 & 2.14 & 0.11 & $\begin{array}{l}\text { Fine sediment (mud, } \\
\text { silt) }\end{array}$ & No & Crest & 25,700 & 26,400 \\
\hline
\end{tabular}


Table 4. Reach map data for sturgeon relocations on reach maps within 7 days and 10 percent discharge.—Continued

$\left[\mathrm{m}\right.$, meter; $\mathrm{m} / \mathrm{s}$, meter per second; SWH, shallow-water habitat (depth $<1.5 \mathrm{~m}$, velocity $<0.6 \mathrm{~m} / \mathrm{s}$ ); $\mathrm{ft}^{3} / \mathrm{s}$, cubic foot per second; --, no data]

\begin{tabular}{|c|c|c|c|c|c|c|c|c|c|c|c|c|c|}
\hline $\begin{array}{l}\text { Sturgeon } \\
\text { identification } \\
\text { code }\end{array}$ & $\begin{array}{c}\text { River mile } \\
\text { of sturgeon } \\
\text { relocation }\end{array}$ & $\begin{array}{c}\text { Relocation } \\
\text { date }\end{array}$ & $\begin{array}{c}\text { Map } \\
\text { identification }\end{array}$ & $\begin{array}{c}\text { Depth } \\
\text { (m) }\end{array}$ & $\begin{array}{c}\text { Depth } \\
\text { slope } \\
\text { (degrees) }\end{array}$ & $\begin{array}{c}\text { Velocity } \\
\text { (m/s) }\end{array}$ & $\begin{array}{c}\text { Velocity } \\
\text { gradient } \\
\text { (percent per } \\
\text { meter) }\end{array}$ & $\begin{array}{l}\text { Froude } \\
\text { number }\end{array}$ & Substrate & SWH & $\begin{array}{l}\text { Terrain } \\
\text { class }\end{array}$ & $\begin{array}{c}\text { Estimated } \\
\text { discharge on } \\
\text { relocation date } \\
\left(\mathrm{ft}^{3} / \mathrm{s}\right)\end{array}$ & $\begin{array}{c}\text { Estimated } \\
\text { discharge } \\
\text { on map date } \\
\left(\mathrm{ft}^{3} / \mathbf{s}\right)\end{array}$ \\
\hline SNS05-058 & 672.5 & June 1, 2005 & 20050602_f & 2.0 & 0.7 & 0.63 & 1.41 & 0.14 & Sand (dunes) & No & Crest & 28,800 & 29,300 \\
\hline SNS05-074 & 672.3 & May 26, 2005 & 20050602_f & 7.2 & 1.5 & 1.44 & 0.48 & 0.17 & Sand (dunes) & No & Depression & 28,100 & 29,300 \\
\hline SNS05-052 & 671.8 & June 1, 2005 & 20050602 f & 5.3 & 1.0 & 1.05 & 0.48 & 0.14 & Sand (dunes) & No & Depression & 28,800 & 29,300 \\
\hline SNS05-052 & 671.7 & May 26, 2005 & 20050602 f & 4.3 & 12.2 & 0.91 & 1.21 & 0.15 & Sand (dunes) & No & Depression & 28,100 & 29,300 \\
\hline SNS06-067 & 670.1 & June 8, 2006 & 20060601_f & 4.8 & 2.0 & 1.04 & 0.59 & 0.15 & Sand (dunes) & No & Depression & 28,100 & 26,400 \\
\hline SNS06-067 & 669.4 & May 31, 2006 & 20060601_f & 2.9 & 0.5 & 1.07 & 0.88 & 0.20 & Sand (dunes) & No & Crest & 26,600 & 26,600 \\
\hline SNS06-072 & 669.1 & May 31, 2006 & 20060601_f & 5.5 & 10.3 & 0.71 & 2.81 & 0.10 & Sand (dunes) & No & Depression & 28,900 & 28,800 \\
\hline SNS06-084 & 666.5 & June 8, 2006 & 20060606_f & 5.3 & 9.8 & 0.58 & 1.50 & 0.08 & $\begin{array}{l}\text { Engineered structures } \\
\text { (rock) }\end{array}$ & No & Depression & 29,900 & 28,700 \\
\hline SNS06-072 & 666.0 & June 8, 2006 & 20060606_f & 4.4 & 0.8 & 0.90 & 1.75 & 0.14 & Sand (dunes) & No & Flat & 29,900 & 28,700 \\
\hline SNS06-072 & 666.0 & June 8, 2006 & 20060606_f & 4.1 & 3.4 & 0.78 & 1.43 & 0.12 & Sand (dunes) & No & Flat & 29,900 & 28,700 \\
\hline SNS06-089 & 665.9 & June 8, 2006 & 20060606_f & 5.8 & 8.5 & 0.92 & 2.03 & 0.12 & Sand (dunes) & No & Depression & 29,900 & 28,700 \\
\hline SNS06-089 & 665.8 & May 31, 2006 & 20060606_f & 1.4 & 5.8 & 0.34 & 1.78 & 0.09 & $\begin{array}{l}\text { Fine sediment (mud, } \\
\text { silt) }\end{array}$ & Yes & Crest & 28,900 & 28,700 \\
\hline SNS05-074 & 662.8 & June 7, 2005 & 20050608 f & 4.2 & 2.1 & 1.12 & 1.51 & 0.18 & Sand (dunes) & No & Crest & 40,900 & 44,700 \\
\hline SNS07-033 & 660.7 & May 11, 2007 & 20070512_f & 3.7 & 12.0 & 0.75 & 2.42 & 0.13 & -- & No & Crest & 36,300 & 36,500 \\
\hline SNS05-071 & 657.9 & May 18,2005 & 20050519_f & 3.4 & 2.0 & & & & -- & -- & Crest & 31,400 & 30,900 \\
\hline SNS05-097 & 657.3 & May 18,2005 & 20050519_f & 1.7 & 7.8 & & & & -- & -- & Crest & 31,400 & 30,900 \\
\hline SNS05-058 & 654.6 & May 6, 2005 & 20050507_f & 3.8 & 6.5 & 0.96 & 1.12 & 0.16 & Sand (dunes) & No & Slope & 26,500 & 26,500 \\
\hline SNS05-084 & 651.9 & May 24, 2005 & $20050525 \_f$ & 2.4 & 2.3 & 0.58 & 1.99 & 0.12 & Sand (dunes) & No & Crest & 30,400 & 29,400 \\
\hline SNS05-061 & 651.8 & May 24, 2005 & 20050525 f & 2.9 & 13.6 & 0.70 & 3.04 & 0.12 & $\begin{array}{l}\text { Engineered structures } \\
\text { (rock) }\end{array}$ & No & Crest & 30,400 & 29,400 \\
\hline SNS05-061 & 651.8 & May 18, 2005 & 20050525 f & 4.0 & 17.5 & 0.80 & 3.02 & 0.12 & $\begin{array}{l}\text { Engineered structures } \\
\quad \text { (rock) }\end{array}$ & No & Crest & 31,400 & 29,400 \\
\hline SNS07-030 & 650.8 & June 1, 2007 & 20070608_f & 3.3 & 1.2 & 0.93 & 0.26 & 0.16 & Sand (dunes) & No & Crest & 30,300 & 31,200 \\
\hline SNS07-030 & 650.7 & June 7, 2007 & 20070608_f & 1.9 & 4.3 & 0.47 & 1.40 & 0.11 & Sand (dunes) & No & Crest & 31,600 & 31,200 \\
\hline SNS05-094 & 650.5 & June 22, 2005 & $20050623 \_f$ & 3.4 & 8.2 & 0.85 & 2.03 & 0.15 & $\begin{array}{l}\text { Engineered structures } \\
\text { (rock) }\end{array}$ & No & Crest & 33,300 & 33,800 \\
\hline SNS07-025 & 650.4 & June 13, 2007 & 20070608_f & 4.2 & 1.3 & 1.12 & 0.40 & 0.17 & Sand (dunes) & No & Flat & 29,800 & 31,200 \\
\hline SNS07-025 & 650.4 & June 7, 2007 & 20070608_f & 4.4 & 1.4 & 1.13 & 0.49 & 0.17 & Sand (dunes) & No & Flat & 31,600 & 31,200 \\
\hline SNS07-025 & 650.4 & June 1, 2007 & 20070608_f & 4.3 & 0.3 & 1.09 & 0.21 & 0.17 & Sand (dunes) & No & Flat & 30,300 & 31,200 \\
\hline SNS05-094 & 650.2 & June 30, 2005 & 20050623_f & 4.0 & 0.9 & 1.22 & 0.26 & 0.20 & Sand (dunes) & No & Flat & 34,700 & 33,800 \\
\hline SNS07-009 & 650.2 & June 7, 2007 & $20070608 \_f$ & 1.9 & 7.4 & 0.63 & 1.55 & 0.15 & Sand (dunes) & Yes & Crest & 31,600 & 31,200 \\
\hline SNS06-075 & 650.1 & June 13, 2007 & $20070608 \_f$ & 3.3 & 1.1 & 1.11 & 0.42 & 0.20 & $\begin{array}{l}\text { Revetment, gravel, } \\
\text { hard sand }\end{array}$ & No & Crest & 29,800 & 31,200 \\
\hline SNS07-030 & 650.0 & June 13, 2007 & 20070608_f & 3.9 & 0.9 & 1.22 & 0.80 & 0.20 & Transporting sand & No & Flat & 29,800 & 31,200 \\
\hline SNS07-066 & 649.5 & June 7, 2007 & $20070608 \_f$ & 2.8 & 1.3 & 0.53 & 0.78 & 0.10 & Sand (dunes) & No & Crest & 31,600 & 31,200 \\
\hline SNS07-042 & 649.5 & June 7, 2007 & 20070608_f & 2.8 & 0.9 & 0.63 & 1.39 & 0.12 & Transporting sand & No & Crest & 31,600 & 31,200 \\
\hline
\end{tabular}


Table 4. Reach map data for sturgeon relocations on reach maps within 7 days and 10 percent discharge.-Continued

[m, meter; m/s, meter per second; SWH, shallow-water habitat (depth $<1.5 \mathrm{~m}$, velocity $<0.6 \mathrm{~m} / \mathrm{s}$ ); $\mathrm{ft}^{3} / \mathrm{s}$, cubic foot per second; --, no data]

\begin{tabular}{|c|c|c|c|c|c|c|c|c|c|c|c|c|c|}
\hline $\begin{array}{l}\text { Sturgeon } \\
\text { identification } \\
\text { code }\end{array}$ & $\begin{array}{c}\text { River mile } \\
\text { of sturgeon } \\
\text { relocation }\end{array}$ & $\begin{array}{l}\text { Relocation } \\
\text { date }\end{array}$ & $\begin{array}{c}\text { Map } \\
\text { identification }\end{array}$ & $\begin{array}{l}\text { Depth } \\
\text { (m) }\end{array}$ & $\begin{array}{c}\text { Depth } \\
\text { slope } \\
\text { (degrees) }\end{array}$ & $\begin{array}{c}\text { Velocity } \\
(\mathrm{m} / \mathrm{s})\end{array}$ & $\begin{array}{c}\text { Velocity } \\
\text { gradient } \\
\text { (percent per } \\
\text { meter) }\end{array}$ & $\begin{array}{l}\text { Froude } \\
\text { number }\end{array}$ & Substrate & SWH & $\begin{array}{l}\text { Terrain } \\
\text { class }\end{array}$ & $\begin{array}{c}\text { Estimated } \\
\text { discharge on } \\
\text { relocation date } \\
\left(\mathrm{ft}^{3} / \mathrm{s}\right)\end{array}$ & $\begin{array}{c}\text { Estimated } \\
\text { discharge } \\
\text { on map date } \\
\left(\mathrm{ft}^{3} / \mathrm{s}\right)\end{array}$ \\
\hline 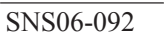 & 648.4 & April 30, 2007 & 20070501_f & 5.1 & 2.4 & 1.07 & 1.78 & 0.15 & Sand (dunes) & No & Depression & 29,900 & 28,000 \\
\hline SNS07-045 & 647.8 & April 30, 2007 & 20070501_f & 1.8 & 2.4 & 0.64 & 1.18 & 0.15 & Sand (dunes) & No & Crest & 29,900 & 28,000 \\
\hline SNS07-175 & 646.7 & April 30, 2007 & 20070501_f & 2.7 & 9.5 & 0.85 & 2.84 & 0.18 & Sand (dunes) & No & Crest & 29,900 & 28,000 \\
\hline SNS05-054 & 644.8 & June 13, 2005 & 20050614_f & 8.9 & 4.1 & 0.72 & 3.83 & 0.08 & Sand (dunes) & No & Depression & 38,000 & 36,200 \\
\hline SNS05-099 & 643.4 & August 9, 2005 & 20050812_f & 4.6 & 0.7 & 0.80 & 1.12 & 0.12 & -- & No & Flat & 27,100 & 28,100 \\
\hline SNS07-077 & 643.4 & June 13, 2007 & 20070614_f & 4.4 & 1.4 & 0.93 & 0.57 & 0.14 & Sand (dunes) & No & Flat & 29,800 & 30,100 \\
\hline SNS07-009 & 642.7 & June 19, 2007 & 20070614_f & 3.9 & 0.6 & 0.68 & 1.80 & 0.11 & Transporting sand & No & Flat & 28,900 & 30,100 \\
\hline SNS06-077 & 641.5 & May 17, 2006 & 20060518_f & 4.5 & 9.3 & 0.74 & 5.39 & 0.11 & Sand (dunes) & No & Slope & 35,400 & 34,400 \\
\hline SNS07-176 & 640.9 & June 14, 2007 & $20070616 \_f$ & 4.7 & 2.2 & 0.82 & 0.88 & 0.12 & Sand (dunes) & No & Depression & 30,100 & 29,600 \\
\hline SNS07-176 & 640.9 & June 19, 2007 & 20070616_f & 4.8 & 0.8 & 0.93 & 1.18 & 0.14 & Sand (dunes) & No & Depression & 28,900 & 29,600 \\
\hline SNS07-176 & 640.8 & June 21, 2007 & 20070616_f & 4.8 & 2.3 & 0.85 & 1.19 & 0.13 & Sand (dunes) & No & Depression & 28,700 & 29,600 \\
\hline SNS07-034 & 640.8 & June 21, 2007 & 20070616_f & 2.9 & 5.1 & 0.77 & 2.46 & 0.14 & Sand (dunes) & No & Crest & 28,700 & 29,600 \\
\hline SNS07-034 & 640.7 & June 19, 2007 & 20070616_f & 3.6 & 6.0 & 0.89 & 2.71 & 0.14 & Sand (dunes) & No & Slope & 28,900 & 29,600 \\
\hline SNS07-034 & 640.6 & June 14, 2007 & 20070616_f & 6.7 & 4.5 & 1.14 & 2.31 & 0.14 & Sand (dunes) & No & Depression & 30,100 & 29,600 \\
\hline SNS05-061 & 640.2 & May 10,2005 & $20050505 \_f$ & 0.0 & 0.0 & 0.79 & 1.02 & 0.11 & $\begin{array}{l}\text { Engineered structures } \\
\text { (rock) }\end{array}$ & -- & -- & 28,300 & 27,400 \\
\hline SNS05-061 & 639.7 & June 6, 2005 & 20050601_f & 3.0 & 5.4 & 0.58 & 1.03 & 0.11 & Sand (dunes) & No & Crest & 33,800 & 32,600 \\
\hline SNS05-061 & 639.7 & May 6, 2005 & 20050505_f & 0.0 & 0.0 & 0.54 & 1.16 & 0.12 & Sand (dunes) & -- & -- & 26,500 & 27,400 \\
\hline SNS05-061 & 639.6 & May 31, 2005 & 20050601_f & 4.2 & 16.5 & 0.71 & 0.87 & 0.11 & $\begin{array}{l}\text { Revetment, gravel, } \\
\text { hard sand }\end{array}$ & No & Slope & 31,600 & 32,600 \\
\hline SNS05-101 & 638.2 & June 6, 2005 & 20050601_f & 7.7 & 1.9 & 1.03 & 0.89 & 0.12 & Sand (dunes) & No & Depression & 33,800 & 32,600 \\
\hline SNS05-101 & 638.2 & May 31, 2005 & 20050601_f & 5.2 & 15.0 & 0.77 & 3.14 & 0.11 & $\begin{array}{l}\text { Engineered structures } \\
\quad \text { (rock) }\end{array}$ & No & Slope & 31,600 & 32,600 \\
\hline SNS05-076 & 622.7 & June 20, 2005 & 20050622_f & 6.5 & 1.0 & 0.89 & 1.09 & 0.11 & Sand (dunes) & No & Depression & 35,500 & 33,800 \\
\hline SNS05-060 & 622.2 & June 28,2005 & $20050622 \_f$ & 4.8 & 17.3 & 0.58 & 4.06 & 0.09 & $\begin{array}{l}\text { Fine sediment (mud, } \\
\text { silt) }\end{array}$ & No & Slope & 37,100 & 33,800 \\
\hline SNS05-095 & 620.0 & May 11,2005 & 20050512_f & 4.9 & 8.5 & 1.01 & 1.54 & 0.14 & $\begin{array}{l}\text { Engineered structures } \\
\quad \text { (rock) }\end{array}$ & No & Depression & 32,200 & 34,000 \\
\hline SNS05-100 & 618.8 & June 20, 2005 & 20050621_f & 1.9 & 7.1 & 0.45 & 1.46 & 0.10 & Sand (dunes) & No & Crest & 35,500 & 34,600 \\
\hline SNS05-076 & 618.6 & June 28,2005 & 20050621_f & 1.7 & 6.0 & 0.32 & 0.92 & 0.08 & Sand (dunes) & No & Crest & 37,100 & 34,600 \\
\hline SNS05-070 & 611.6 & May 5, 2005 & $20050428 \_f$ & 7.5 & 14.4 & 0.96 & 2.48 & 0.11 & $\begin{array}{l}\text { Engineered structures } \\
\text { (rock) }\end{array}$ & No & Depression & 27,700 & 25,100 \\
\hline SNS05-098 & 610.4 & May 7, 2005 & 20050506_f & 5.5 & 6.9 & 0.67 & 2.49 & 0.09 & Transporting sand & No & Depression & 26,800 & 26,800 \\
\hline SNS05-075 & 610.2 & May 5, 2005 & 20050506_f & 3.6 & 7.2 & 0.81 & 0.51 & 0.13 & -- & No & Slope & 27,700 & 26,800 \\
\hline
\end{tabular}


Table 4. Reach map data for sturgeon relocations on reach maps within 7 days and 10 percent discharge.-Continued

$\left[\mathrm{m}\right.$, meter; $\mathrm{m} / \mathrm{s}$, meter per second; SWH, shallow-water habitat (depth $<1.5 \mathrm{~m}$, velocity $<0.6 \mathrm{~m} / \mathrm{s}$ ); $\mathrm{ft}^{3} / \mathrm{s}$, cubic foot per second; --, no data]

\begin{tabular}{|c|c|c|c|c|c|c|c|c|c|c|c|c|c|}
\hline $\begin{array}{l}\text { Sturgeon } \\
\text { identification } \\
\text { code }\end{array}$ & $\begin{array}{l}\text { River mile } \\
\text { of sturgeon } \\
\text { relocation }\end{array}$ & $\begin{array}{l}\text { Relocation } \\
\text { date }\end{array}$ & $\begin{array}{c}\text { Map } \\
\text { identification }\end{array}$ & $\begin{array}{l}\text { Depth } \\
\text { (m) }\end{array}$ & $\begin{array}{c}\text { Depth } \\
\text { slope } \\
\text { (degrees) }\end{array}$ & $\begin{array}{c}\text { Velocity } \\
(\mathrm{m} / \mathrm{s})\end{array}$ & $\begin{array}{c}\text { Velocity } \\
\text { gradient } \\
\text { (percent per } \\
\text { meter) }\end{array}$ & $\begin{array}{l}\text { Froude } \\
\text { number }\end{array}$ & Substrate & SWH & $\begin{array}{l}\text { Terrain } \\
\text { class }\end{array}$ & $\begin{array}{c}\text { Estimated } \\
\text { discharge on } \\
\text { relocation date } \\
\left(\mathrm{ft}^{3} / \mathrm{s}\right)\end{array}$ & $\begin{array}{c}\text { Estimated } \\
\text { discharge } \\
\text { on map date } \\
\left(\mathrm{ft}^{3} / \mathrm{s}\right)\end{array}$ \\
\hline SNS05-075 & 610.2 & May 7, 2005 & 20050506_f & 4.4 & 4.3 & 0.83 & 0.76 & 0.13 & $\begin{array}{l}\text { Engineered structures } \\
\text { (rock) }\end{array}$ & No & Depression & 26,800 & 26,800 \\
\hline SNS05-072 & 609.9 & June 3, 2005 & 20050605_f & 3.1 & 2.1 & 0.60 & 1.51 & 0.11 & Sand (dunes) & No & Crest & 33,600 & 33,100 \\
\hline SNS05-096 & 609.9 & May 5, 2005 & 20050506_f & 2.6 & 3.6 & 0.84 & 0.74 & 0.17 & Sand (dunes) & No & Crest & 27,700 & 26,800 \\
\hline SNS05-097 & 609.8 & May 7, 2005 & 20050506_f & 5.0 & 4.9 & 0.84 & 3.20 & 0.12 & Transporting sand & No & Depression & 26,800 & 26,800 \\
\hline SNS05-071 & 609.4 & May 5, 2005 & 20050506_f & 6.9 & 13.6 & 0.24 & 2.60 & 0.03 & Sand (dunes) & No & Depression & 27,700 & 26,800 \\
\hline SNS05-068 & 609.2 & May 7, 2005 & 20050506 f & 6.6 & 8.4 & 0.63 & 2.01 & 0.08 & Transporting sand & No & Depression & 26,800 & 26,800 \\
\hline SNS05-074 & 609.1 & May 5, 2005 & 20050508_f & 2.4 & 0.7 & 0.70 & 0.75 & 0.14 & Sand (dunes) & No & Crest & 27,700 & 28,000 \\
\hline SNS05-076 & 609.1 & May 7, 2005 & 20050508_f & 3.7 & 3.3 & 0.94 & 1.69 & 0.15 & Sand (dunes) & No & Flat & 26,800 & 28,000 \\
\hline SNS05-068 & 609.1 & May 5, 2005 & $20050508 \_f$ & 2.9 & 4.6 & 0.80 & 0.97 & 0.15 & Sand (dunes) & No & Crest & 27,700 & 28,000 \\
\hline SNS05-076 & 609.0 & May 5, 2005 & 20050429 f & 5.0 & 8.7 & 0.66 & 1.11 & 0.09 & Sand (dunes) & No & Depression & 27,700 & 25,100 \\
\hline SNS05-082 & 608.9 & May 5, 2005 & 20050508_f & 1.8 & 1.2 & 0.61 & 0.83 & 0.15 & Sand (dunes) & No & Crest & 27,700 & 28,000 \\
\hline SNS05-084 & 608.8 & May 5, 2005 & 20050508_f & 3.7 & 12.1 & 0.71 & 0.81 & 0.12 & Transporting sand & No & Slope & 27,700 & 28,000 \\
\hline SNS05-072 & 608.8 & May 5, 2005 & 20050508_f & 3.3 & 2.9 & 0.64 & 0.61 & 0.11 & Sand (dunes) & No & Crest & 27,700 & 28,000 \\
\hline SNS05-072 & 608.8 & May 7, 2005 & 20050508_f & 2.8 & 7.1 & 0.65 & 0.31 & 0.12 & $\begin{array}{l}\text { Revetment, gravel, } \\
\text { hard sand }\end{array}$ & No & Crest & 26,800 & 28,000 \\
\hline SNS05-095 & 608.7 & May 7, 2005 & 20050508_f & 7.7 & 14.5 & 0.79 & 1.98 & 0.09 & $\begin{array}{l}\text { Revetment, gravel, } \\
\text { hard sand }\end{array}$ & No & Depression & 26,800 & 28,000 \\
\hline SNS05-082 & 608.6 & May 7, 2005 & 20050508_f & 7.0 & 14.2 & 0.51 & 3.15 & 0.06 & $\begin{array}{l}\text { Fine sediment (mud, } \\
\text { silt) }\end{array}$ & No & Depression & 26,800 & 28,000 \\
\hline SNS05-077 & 608.1 & May 7, 2005 & 20050508_f & 4.9 & 1.0 & 1.03 & 1.06 & 0.15 & Sand (dunes) & No & Flat & 26,800 & 28,000 \\
\hline SNS05-077 & 608.1 & May 5, 2005 & 20050508_f & 5.7 & 3.8 & & & & $\begin{array}{l}\text { Engineered structures } \\
\quad \text { (rock) }\end{array}$ & -- & Depression & 27,700 & 28,000 \\
\hline SNS05-101 & 607.6 & May 7, 2005 & $20050508 \_f$ & 6.3 & 9.5 & 0.77 & 3.52 & 0.10 & $\begin{array}{l}\text { Engineered structures } \\
\text { (rock) }\end{array}$ & No & Depression & 26,800 & 28,000 \\
\hline SNS05-101 & 607.6 & May 5, 2005 & 20050508_f & 5.1 & 4.2 & 0.89 & 1.39 & 0.12 & Sand (dunes) & No & Depression & 27,700 & 28,000 \\
\hline SNS05-083 & 607.5 & May 7, 2005 & 20050508_f & 3.7 & 2.5 & 0.88 & 1.22 & 0.15 & Sand (dunes) & No & Flat & 26,800 & 28,000 \\
\hline SNS05-083 & 607.5 & May 5, 2005 & 20050508_f & 4.7 & 1.6 & 0.97 & 0.44 & 0.14 & Sand (dunes) & No & Depression & 27,700 & 28,000 \\
\hline SNS05-082 & 604.6 & June 3, 2005 & 20050604_f & 4.6 & 8.4 & 0.67 & 2.67 & 0.10 & $\begin{array}{l}\text { Fine sediment (mud, } \\
\text { silt) }\end{array}$ & No & Depression & 33,600 & 32,900 \\
\hline SNS05-056 & 603.3 & June 3, 2005 & 20050604_f & 4.5 & 4.9 & 0.76 & 1.28 & 0.11 & Sand (dunes) & No & Slope & 33,600 & 32,900 \\
\hline SNS05-073 & 602.9 & May 8, 2005 & 20050509_f & 3.4 & 10.4 & 1.03 & 1.56 & 0.18 & $\begin{array}{l}\text { Engineered structures } \\
\text { (rock) }\end{array}$ & No & Crest & 28,000 & 28,500 \\
\hline
\end{tabular}


Table 4. Reach map data for sturgeon relocations on reach maps within 7 days and 10 percent discharge.-Continued

$\left[\mathrm{m}\right.$, meter; $\mathrm{m} / \mathrm{s}$, meter per second; SWH, shallow-water habitat (depth $<1.5 \mathrm{~m}$, velocity $<0.6 \mathrm{~m} / \mathrm{s}$ ); $\mathrm{ft}^{3} / \mathrm{s}$, cubic foot per second; --, no data]

\begin{tabular}{|c|c|c|c|c|c|c|c|c|c|c|c|c|c|}
\hline $\begin{array}{l}\text { Sturgeon } \\
\text { identification } \\
\text { code }\end{array}$ & $\begin{array}{c}\text { River mile } \\
\text { of sturgeon } \\
\text { relocation }\end{array}$ & $\begin{array}{l}\text { Relocation } \\
\text { date }\end{array}$ & $\begin{array}{c}\text { Map } \\
\text { identification }\end{array}$ & $\begin{array}{l}\text { Depth } \\
\text { (m) }\end{array}$ & $\begin{array}{c}\text { Depth } \\
\text { slope } \\
\text { (degrees) }\end{array}$ & $\begin{array}{c}\text { Velocity } \\
(\mathrm{m} / \mathrm{s})\end{array}$ & $\begin{array}{c}\text { Velocity } \\
\text { gradient } \\
\text { (percent per } \\
\text { meter) }\end{array}$ & $\begin{array}{l}\text { Froude } \\
\text { number }\end{array}$ & Substrate & SWH & $\begin{array}{l}\text { Terrain } \\
\text { class }\end{array}$ & $\begin{array}{c}\text { Estimated } \\
\text { discharge on } \\
\text { relocation date } \\
\left(\mathrm{ft}^{3} / \mathrm{s}\right)\end{array}$ & $\begin{array}{c}\text { Estimated } \\
\text { discharge } \\
\text { on map date } \\
\left(\mathrm{ft}^{3} / \mathrm{s}\right)\end{array}$ \\
\hline SNS05-069 & 601.9 & May 8, 2005 & 20050509_f & 6.0 & 2.3 & 1.17 & 0.26 & 0.15 & Sand (dunes) & No & Depression & 28,000 & 28,500 \\
\hline SNS05-087 & 601.2 & May 16, 2005 & 20050522_f & 6.8 & 10.8 & 0.61 & 2.42 & 0.08 & Sand (dunes) & No & Depression & 33,300 & 31,100 \\
\hline SNS05-073 & 593.4 & June 10,2005 & 20050611_f & 7.3 & 13.6 & 1.49 & 3.08 & 0.18 & Sand (dunes) & No & Depression & 56,700 & 57,300 \\
\hline SNS05-085 & 588.6 & May 20, 2005 & 20050523 f & 1.9 & 2.2 & 0.43 & 1.27 & 0.10 & Sand (dunes) & No & Crest & 43,700 & 39,400 \\
\hline SNS06-076 & 584.2 & July 6, 2006 & 20060713_f & 3.3 & 5.3 & 0.68 & 3.23 & 0.12 & $\begin{array}{l}\text { Engineered structures } \\
\text { (rock) }\end{array}$ & No & Slope & 30,600 & 30,200 \\
\hline SNS06-076 & 584.2 & July 18, 2006 & 20060713_f & 3.5 & 5.3 & 0.77 & 3.26 & 0.13 & $\begin{array}{l}\text { Engineered structures } \\
\text { (rock) }\end{array}$ & No & Crest & 29,200 & 30,200 \\
\hline SNS06-076 & 584.2 & July 12,2006 & 20060713_f & 3.0 & 8.0 & 0.76 & 3.91 & 0.14 & Sand (dunes) & No & Crest & 30,500 & 30,200 \\
\hline PLS06-006 & 583.8 & July 6, 2006 & 20060713_f & 4.7 & 5.8 & 1.13 & 2.81 & 0.17 & Sand (dunes) & No & Depression & 30,600 & 30,200 \\
\hline PLS06-006 & 583.8 & July 12,2006 & 20060713_f & 4.7 & 1.2 & 1.29 & 0.53 & 0.19 & Sand (dunes) & No & Depression & 30,500 & 30,200 \\
\hline PLS06-006 & 583.8 & July 18,2006 & 20060713_f & 3.4 & 4.4 & 0.96 & 1.77 & 0.17 & $\begin{array}{l}\text { Revetment, gravel, } \\
\text { hard sand }\end{array}$ & No & Crest & 29,200 & 30,200 \\
\hline SNS05-070 & 565.3 & May 20, 2005 & 20050524_f & 2.4 & 2.9 & 0.46 & 0.91 & 0.10 & Sand (dunes) & No & Crest & 43,700 & 39,600 \\
\hline PLS06-003 & 331.6 & June 19, 2006 & 20060620_b & 2.3 & 5.8 & 0.21 & 0.79 & 0.04 & $\begin{array}{l}\text { Fine sediment (mud, } \\
\text { silt) }\end{array}$ & No & Crest & 35,600 & 35,600 \\
\hline SNS05-006 & 330.1 & April 28, 2005 & 20050429_b & 2.5 & 0.7 & 0.84 & 0.65 & 0.17 & -- & No & Crest & 44,400 & 43,300 \\
\hline PLS06-004 & 327.0 & May 31, 2006 & $20060524 \_b$ & 3.0 & 1.7 & 0.79 & 0.55 & 0.15 & Sand (dunes) & No & Crest & 40,400 & 38,600 \\
\hline PLS06-004 & 326.8 & May 25, 2006 & 20060524_b & 3.4 & 1.2 & 1.13 & 0.41 & 0.20 & Sand (dunes) & No & Crest & 38,000 & 38,600 \\
\hline PLS06-004 & 326.6 & May 23, 2006 & 20060524 b & 4.6 & 5.5 & 0.83 & 2.47 & 0.12 & Sand (dunes) & No & Slope & 38,700 & 38,600 \\
\hline PLS06-004 & 326.4 & May 17, 2006 & 20060524_b & 6.8 & 10.3 & 0.60 & 4.13 & 0.07 & Sand (dunes) & No & Depression & 38,200 & 38,600 \\
\hline SNS05-041 & 324.9 & May 10, 2005 & 20050511_b & 1.4 & 1.6 & 0.63 & 0.52 & 0.17 & -- & No & Crest & 36,600 & 37,600 \\
\hline SNS05-037 & 315.3 & April 26, 2005 & 20050427_b & 5.4 & 0.5 & 1.13 & 0.42 & 0.16 & -- & No & Depression & 47,500 & 45,000 \\
\hline SNS05-007 & 311.5 & May 4, 2005 & 20050505_b & 5.0 & 4.5 & 1.00 & 0.47 & 0.14 & -- & No & Depression & 39,400 & 39,200 \\
\hline SNS05-003 & 291.7 & May 25, 2005 & 20050526_b & 2.8 & 4.1 & 0.55 & 0.79 & 0.10 & -- & No & Flat & 53,000 & 53,000 \\
\hline SNS06-038 & 289.4 & July 11, 2006 & 20060706_b & 2.9 & 1.4 & 0.90 & 0.77 & 0.17 & Sand (dunes) & No & Crest & 35,700 & 36,200 \\
\hline SNS06-038 & 289.4 & July 5, 2006 & 20060706_b & 2.8 & 1.9 & 0.82 & 0.99 & 0.16 & Sand (dunes) & No & Crest & 38,000 & 36,200 \\
\hline SNS06-047 & 281.1 & June 7, 2006 & 20060613_b_b & 3.4 & 1.4 & 0.81 & 0.55 & 0.14 & Sand (dunes) & No & Flat & 39,600 & 36,700 \\
\hline SNS06-047 & 281.1 & June 13, 2006 & 20060613_b_b & 2.2 & 4.2 & 0.62 & 1.15 & 0.13 & Sand (dunes) & No & Crest & 36,700 & 36,700 \\
\hline SNS06-047 & 281.1 & June 20, 2006 & 20060613_b_b & 3.1 & 1.9 & 0.62 & 1.10 & 0.11 & Sand (dunes) & No & Crest & 35,900 & 36,700 \\
\hline SNS05-015 & 275.6 & June 9, 2005 & 20050610_b & 5.5 & 2.3 & 1.22 & 1.20 & 0.17 & -- & No & Crest & 88,700 & 84,400 \\
\hline SNS06-034 & 248.1 & June 1, 2006 & $20060602 \_b$ & 1.6 & 1.9 & 0.37 & 0.60 & 0.09 & $\begin{array}{l}\text { Revetment, gravel, } \\
\text { hard sand }\end{array}$ & No & Crest & 45,400 & 45,700 \\
\hline
\end{tabular}


Table 4. Reach map data for sturgeon relocations on reach maps within 7 days and 10 percent discharge.—Continued

$\left[\mathrm{m}\right.$, meter; $\mathrm{m} / \mathrm{s}$, meter per second; SWH, shallow-water habitat (depth $<1.5 \mathrm{~m}$, velocity $<0.6 \mathrm{~m} / \mathrm{s}$ ); $\mathrm{ft}^{3} / \mathrm{s}$, cubic foot per second; --, no data]

\begin{tabular}{|c|c|c|c|c|c|c|c|c|c|c|c|c|c|}
\hline $\begin{array}{l}\text { Sturgeon } \\
\text { identification } \\
\text { code }\end{array}$ & $\begin{array}{c}\text { River mile } \\
\text { of sturgeon } \\
\text { relocation }\end{array}$ & $\begin{array}{c}\text { Relocation } \\
\text { date }\end{array}$ & $\begin{array}{c}\text { Map } \\
\text { identification }\end{array}$ & $\begin{array}{c}\text { Depth } \\
\text { (m) }\end{array}$ & $\begin{array}{c}\text { Depth } \\
\text { slope } \\
\text { (degrees) }\end{array}$ & $\begin{array}{c}\text { Velocity } \\
\text { (m/s) }\end{array}$ & $\begin{array}{c}\text { Velocity } \\
\text { gradient } \\
\text { (percent per } \\
\text { meter) }\end{array}$ & $\begin{array}{l}\text { Froude } \\
\text { number }\end{array}$ & Substrate & SWH & $\begin{array}{l}\text { Terrain } \\
\text { class }\end{array}$ & $\begin{array}{c}\text { Estimated } \\
\text { discharge on } \\
\text { relocation date } \\
\left(\mathrm{ft}^{3} / \mathrm{s}\right)\end{array}$ & $\begin{array}{c}\text { Estimated } \\
\text { discharge } \\
\text { on map date } \\
\left(\mathrm{ft}^{3} / \mathrm{s}\right)\end{array}$ \\
\hline SNS05-019 & 230.6 & May 5, 2005 & 20050506_b & 2.3 & 2.3 & 0.30 & 1.38 & 0.06 & -- & No & Crest & 43,100 & 42,700 \\
\hline SNS06-028 & 219.2 & May 18, 2006 & 20060519_b & 1.1 & 4.1 & 0.23 & 1.37 & 0.07 & Sand (dunes) & Yes & Crest & 40,200 & 39,700 \\
\hline PLS04-001 & 219.2 & April 14, 2005 & 20050415_b & 4.0 & 6.6 & 0.96 & 0.76 & 0.15 & -- & No & Crest & 72,100 & 69,500 \\
\hline SNS05-089 & 216.7 & June 24, 2005 & 20050627_b & 2.0 & 1.8 & 0.73 & 0.74 & 0.17 & -- & No & Crest & 70,700 & 68,900 \\
\hline SNS05-028 & 216.5 & June 24, 2005 & 20050627_b & 5.1 & 2.6 & 0.70 & 1.32 & 0.10 & -- & No & Flat & 70,700 & 68,900 \\
\hline SNS05-017 & 202.8 & April 27, 2005 & 20050428_b & 7.2 & 1.7 & 1.16 & 1.84 & 0.14 & -- & No & Depression & 57,900 & 53,300 \\
\hline SNS05-042 & 201.8 & April 8, 2005 & 20050407_b & 3.9 & 6.8 & 0.41 & 1.92 & 0.07 & -- & No & Slope & 40,000 & 38,700 \\
\hline SNS05-034 & 201.3 & April 6, 2005 & 20050407_b & 2.9 & 6.8 & 0.45 & 1.23 & 0.08 & -- & No & Crest & 38,100 & 38,700 \\
\hline PLS04-002 & 199.6 & April 7, 2005 & $20050408 \_\mathrm{f}$ & 4.4 & 3.2 & 0.62 & 2.71 & 0.09 & $\begin{array}{l}\text { Engineered structures } \\
\quad \text { (rock) }\end{array}$ & No & Flat & 38,700 & 40,000 \\
\hline PLS04-002 & 199.5 & April 6, 2005 & 20050408_f & 2.4 & 0.3 & 0.38 & 3.13 & 0.08 & Sand (dunes) & No & Crest & 38,100 & 40,000 \\
\hline SNS06-011 & 195.9 & July 6, 2006 & 20060707_b & 3.7 & 4.5 & 0.56 & 2.86 & 0.09 & Sand (dunes) & No & Flat & 38,500 & 38,000 \\
\hline SNS06-011 & 195.9 & July 12, 2006 & 20060707_b & 3.6 & 3.1 & 0.68 & 2.85 & 0.12 & Sand (dunes) & No & Flat & 36,000 & 38,000 \\
\hline SNS05-026 & 186.5 & May 26, 2005 & 20050527_b & 5.4 & 19.8 & 0.78 & 4.71 & 0.11 & -- & No & Slope & 61,300 & 59,500 \\
\hline SNS05-027 & 177.9 & April 11, 2005 & $20050412 \_b$ & 1.0 & 1.3 & 0.55 & 0.46 & 0.18 & -- & Yes & Crest & 44,100 & 48,500 \\
\hline PLS06-001 & 177.2 & May 9, 2006 & 20060510_b & 6.8 & 12.1 & 1.15 & 6.86 & 0.14 & Sand (dunes) & No & Depression & 55,700 & 54,000 \\
\hline SNS05-031 & 173.5 & May 27, 2005 & 20050601_b & 1.5 & 1.4 & 0.58 & 0.45 & 0.15 & -- & No & Crest & 59,500 & 53,600 \\
\hline PLS04-001 & 168.0 & June 30, 2005 & 20050701_b & 6.2 & 1.0 & 1.39 & 0.55 & 0.18 & -- & No & Depression & 62,100 & 65,400 \\
\hline SNS06-010 & 165.5 & June 20, 2006 & 20060621_b & 2.4 & 6.4 & 0.68 & 1.63 & 0.14 & Sand (dunes) & No & Crest & 37,700 & 37,600 \\
\hline SNS05-043 & 160.7 & May 6, 2005 & 20050510_b & 2.9 & 1.3 & 0.45 & 0.64 & 0.08 & -- & No & Crest & 43,600 & 40,500 \\
\hline SNS05-031 & 146.4 & August 3, 2005 & 20050810_b & 4.2 & 3.2 & 0.96 & 1.22 & 0.15 & -- & No & Depression & 37,600 & 35,000 \\
\hline SNS05-021 & 142.1 & August 3, 2005 & $20050809 \_b$ & 2.0 & 2.0 & 0.65 & 2.30 & 0.15 & -- & No & Crest & 37,600 & 35,100 \\
\hline PLS05-003 & 140.9 & May 27, 2005 & 20050602 b & 2.2 & 3.2 & 0.60 & 1.94 & 0.13 & -- & No & Crest & 59,500 & 54,000 \\
\hline PLS05-001 & 130.8 & April 18, 2005 & $20050419 \_b$ & 4.6 & 0.4 & 1.11 & 1.76 & 0.17 & -- & No & Depression & 58,300 & 53,600 \\
\hline SNS05-007 & 130.3 & April 13, 2005 & $20050419 \_b$ & 4.2 & 0.7 & 0.73 & 0.53 & 0.11 & -- & No & Flat & 49,700 & 53,600 \\
\hline SNS05-043 & 130.0 & April 13, 2005 & 20050419_b & 5.4 & 2.6 & 0.23 & 0.62 & 0.03 & -- & No & Flat & 49,700 & 53,600 \\
\hline SNS06-012 & 127.5 & May 8, 2006 & 20060509_b & 2.5 & 0.8 & 0.47 & 1.32 & 0.10 & Sand (dunes) & No & Flat & 74,400 & 69,700 \\
\hline PLS05-002 & 127.1 & April 25, 2005 & 20050426_b & 6.8 & 2.7 & 1.10 & 0.39 & 0.13 & -- & No & Depression & 92,700 & 86,500 \\
\hline PLS06-001 & 119.6 & June 29, 2006 & 20060630_b & 2.5 & 5.4 & 0.51 & 2.14 & 0.11 & Sand (dunes) & No & Crest & 43,300 & 41,700 \\
\hline PLS06-001 & 119.5 & July 7, 2006 & 20060630_b & 3.4 & 0.6 & 0.93 & 0.28 & 0.16 & Sand (dunes) & No & Flat & 40,900 & 41,700 \\
\hline PLS04-003 & 118.4 & May 2, 2005 & $20050503 \_b$ & 7.6 & 8.1 & 0.30 & 1.95 & 0.04 & -- & No & Depression & 55,500 & 52,700 \\
\hline PLS04-003 & 117.8 & July 5,2005 & 20050706_b & 4.0 & 3.9 & 0.73 & 1.47 & 0.12 & -- & No & Flat & 71,800 & 66,800 \\
\hline PLS05-004 & 75.7 & July 6, 2005 & 20050707_b & 1.8 & 2.7 & 0.57 & 0.49 & 0.13 & -- & No & Crest & 67,400 & 70,600 \\
\hline SNS05-017 & 27.3 & July 7, 2005 & 20050708_b & 3.7 & 2.8 & 0.73 & 1.16 & 0.12 & -- & No & Crest & 68,500 & 71,800 \\
\hline
\end{tabular}


Publishing support provided by:

Rolla Publishing Service Center

For more information concerning this publication, contact:

Director, USGS Columbia Environmental Research Center

4200 New Haven Road

Columbia, MO 65201

(573) 875-5399

Or visit the Columbia Environmental Research Center Web site at: http://www.cerc.usgs.gov 

